Hugo Fernando Salinas Fortes Júnior

\title{
Poéticas líquidas: a água na arte contemporânea.
}

Tese apresentada à Área de Concentração: Artes Plásticas da Escola de Comunicações e Artes da Universidade de São Paulo, como exigência parcial para obtenção do Título de Doutor em Artes, sob a orientação do Prof. Dr. Donato Ferrari.

São Paulo, 2006 
Esta pesquisa foi realizada no Brasil e na Alemanha, com o apoio do DAAD (Deutscher Akademischer Austauschdienst Serviço de Intercâmbio Acadêmico Alemão) e da CAPES (Coordenação de Apoio à Pesquisa)

Orientador: Prof. Dr. Donato Ferrari Co-orientador na Alemanha: Prof. Dr. Andreas Haus 
Banca Examinadora 


\section{Resumo}

Esta pesquisa busca investigar a presença da água como material e poética na arte contemporânea. São consideradas as representações históricas e as conotações da água na arte e na cultura, porém o que se destaca são as inovações trazidas pelo emprego da água enquanto matéria, e as conseqüências fenomenológicas que esta utilização traz.

O trabalho abrange tanto o estudo de obras de diversos artistas contemporâneos, brasileiros e internacionais, bem como a análise e comentários oriundos da criação de obras por mim mesmo, enquanto artista. Desta forma, busca-se uma interação entre o pensar e o fazer artístico, afirmando a autonomia da criação em arte. Foram identificados núcleos de análise que englobam os artistas e as obras, mas que constituem categorias fluidas e interdependentes.

Foi realizado um estudo original sobre as relações entre os fenômenos físicoquímicos da água e suas conotações simbólicas nas obras de arte contemporânea. Os conflitos entre a natureza e a cultura permearam todo o trabalho, revelando-se uma questão de grande importância em minha própria poética como artista. Pude identificar interesses pessoais e afinidades por alguns artistas, bem como localizar pontos fundamentais discutidos em meu trabalho artístico.

Palavras chave: água, arte, líquido, material, natureza 


\section{Abstract}

This research investigates the presence of water as material and poetics in the contemporary art. The historic representation and the connotation of water in the art and in the culture are considered, but the emphasis is on the innovations produced by the use of water as matter and the phenomenological consequences of this utilization.

This thesis includes both the study of works from several contemporary artists, Brazilian and international, and the analysis and comments originated on the creation of works by myself, as artist. In forward it is aimed an interaction between the artistic thinking and making, affirming the autonomy of creation in art. Nucleus of analysis including artists and works were identified, but they constitute flowed and interrelated categories.

An original study about the relations between the physical-chemical phenomena of water and its symbolical connotations on the contemporary artworks was developed. The conflict between nature and culture permeates the whole work, revealing itself as an important subject of my own artistic poetics. I could identify personal interests and affinities for some artists, and locate fundamental points discussed by my artistic work.

Keywords: water, art, liquid, material, nature 


\section{Zusammenfassung}

Diese Recherche untersucht die Anwesenheit des Wassers als Material und Poetik in der zeitgenössischen Kunst. Die historischen Repräsentationen und die Konnotationen des Wassers werden eingegangen, aber der Schwerpunkt der Arbeit sind die durch die Verwendung des Wassers als Material entstandenen Innovationen und deren phänomenologischen Folgen.

Die Arbeit umfasst sowohl das Studium von Werken verschiedener brasilianischen und internationalen zeitgenössischen Künstlern, als auch die Analyse und Kommentare zu meiner eigenen künstlerischen Arbeit. So strebt man nach der Interaktion zwischen das künstlerische Denken und Machen und nach der Autonomie des künstlerischen Schaffens. Es wurden Analysekategorien identifiziert, die aber flüssig und gegenseitig abhängig sind.

Ein originelles Studium über die Verbindungen zwischen die physisch-chemischen Phänomene des Wassers und ihre symbolischen Konnotationen in der zeitgenössischen Kunst wurde durchgeführt. Die Konflikte zwischen Natur und Kultur werden in der Arbeit behandelt und spielen eine wichtige Rolle auch bei meiner eigenen Poetik als Künstler. Ich könnte persönliche Interessen und Gemeinsamkeiten mit einigen Künstlern identifizieren und auch grundlegende Frage meiner künstlerischen Arbeit feststellen.

Schlüsselwörter: Wasser, Kunst, Flüssigkeit, Material, Natur 
Para meus pais, Para Síssi Fonseca,

Hugo e Luiza Fortes, que caminha ao meu lado nas águas da arte, minha nascente e meu porto-seguro, mostra-me o fluir das coisas,

fonte de carinho, amor e proteção. e a quem amo profundamente. 


\section{Agradecimentos}

Ao meu querido orientador, Prof. Dr. Donato Ferrari, pela sabedoria, experiência, caráter, simpatia e pela orientação dedicada e apoio constante.

Ao Prof. Dr. Andreas Haus, meu co-orientador na Alemanha, por me oferecer a possibilidade de conhecer um novo mundo, e pela preciosa orientação e competência. Vielen, vielen Dank!

Ao Prof. Dr. Geraldo de Souza Dias, pela amizade e pelos diálogos sobre a arte e a cultura alemã e brasileira.

Ao Prof. Dr. Lorenzo Mammí, pelo interesse e respeito pelo meu trabalho, pela disponibilidade e atenção.

Ao Prof. Dr. Agnaldo Farias, por acreditar em meu projeto e possibilitar o meu desenvolvimento como artista e pesquisador.

Ao DAAD (Serviço de Intercâmbio Acadêmico Alemão) e à CAPES, pela maravilhosa bolsa que me abriu horizontes profissionais e pessoais.

Aos professores da ECA, Prof. Dr. Carlos Fajardo, Prof. Dr. Marco Gianotti, Profa. Dra. Sonia Salzstein, Profa. Dra. Neide Marcondes, Profa. Dra. Ana Maria Tavares, Prof. Dr. Ivan Santo Barbosa, Profa. Dra. Silvia Meira e Profa. Dra. Sílvia Laurentiz, com os quais pude obter uma valiosa formação.

Aos professores da Universität der Künste Berlin, os artistas: Prof. Burkhard Held, Profa. Rebecca Horn, Prof. Lothar Baumgarten, Prof. Tony Cragg, os teóricos: Profa. Dra. Jessica Ulrich, Prof. Dr. Ulrich Seeberg, Prof. Dr. Robert Kudielka, Prof. Dr. Dieter Hahn, e os técnicos: Yoko Hata e Martin Doernbaum, com os quais aprofundei meus conhecimentos na Alemanha e conheci outros pontos de vista.

Ao artista Nuno Ramos, que acompanhou meu trabalho durante vários anos e a quem eu admiro e respeito.

A Rodrigo Naves, pelos ensinamentos estéticos e pelo incentivo ao meu projeto.

A Regina e Stela, secretárias do departamento de artes plásticas da ECA, pela atenção e simpatia. 
Às funcionárias do setor de pós-graduação da ECA.

À Sra. Maria Salgado do DAAD, à Sra. Stephan-Rechenmacher e à Sra. FellaOestemann da UdK, pelo apoio e orientação na Alemanha.

Aos professores e funcionários do Goethe Institut.

Aos meus sogros Esdras e Helena Rosa Fonseca.

Aos meus alunos da Belas Artes (2003) e da Universität der Künste Berlin (2005).

Às equipes do Centro Universitário Maria Antonia e do Centro Cultural São Paulo.

A Fulvia Molina, Stela Barbieri, Mauro de Souza, Lynn Carone, João Carlos de Souza, Viga Gordilho, Horst Hoheisel, Andreas Knitz, Norbert Hinterberger, Gerlinde Pistner, Gabriele Wahl, Reinhard Krehl, Marlyne Sahakyan, Johan Tammer, Karen Tastum, equipe do Schiller Palais, Inge Lindemann, Verena Rose, Melody Burke e Benjamin Kiss, Carola Schmidt, Timm Ulrichs, Stevie Bloomquist, Silvia Marzall, Luciana Caliman e Rogério Gomes de Almeida, Lina Kim e Michael Wesely, Betty Leirner, Chunqing Huan, Christa Schuster, Sonya Weber, Nathalie Jalet, Maki Ueda, Jana Debrodt, Geórgia Kyriakakis, Néle Azevedo, Flávia Vivacqua, Walter Wagner, Márcia Viollante e Phillipe Poezevara, Rosana Fernandes e Falko Lütjen, Sidney Philocreon, Monica Rubinho, Valerie Dantas Mota, Tânia Rivitti, Taísa Palhares, Taís Rivitti, Inês Raphaelian, Regina Teixeira de Barros, Newton Campos, Angela Barbour, Solange Farkas, Wagner Malta Tavares, Ana Paula Oliveira, Regina Johas, Walter Wagner, Sônia Fernandes, Sérgio Malacrida, Valu Oria, Samuel Salinas, André Fortes, Renata Fortes e Flávio Staudohar, Caio Reisewitz, Ilka Spadari e a todos os meus amigos, colegas e familiares, que porventura eu não tenha mencionado, mas que me acompanharam ao longo destes anos.

E em especial à minha cachorrinha Brioche, pelos doces olhinhos e pelas reconfortantes linguadinhas e beijinhos. 


\section{Sumário}

Gota 12

$\begin{array}{ll}\text { Apresentação } & 13\end{array}$

Nascente 15

1. Uma Introdução à história cultural da água 16

Afluentes $\quad 32$

2. A água como representação na arte 33

Correnteza 51

3. A água como presença na arte contemporânea 52

Rio $\quad 91$

4. O fluir de uma poética 92

$\begin{array}{ll}\text { Mergulho } & 142\end{array}$

5. Água: Fenômenos e significação 143

Fontes 165

$\begin{array}{ll}\text { Bibliografia } & 166\end{array}$

$\begin{array}{ll}\text { Sobre o autor } & 173\end{array}$ 


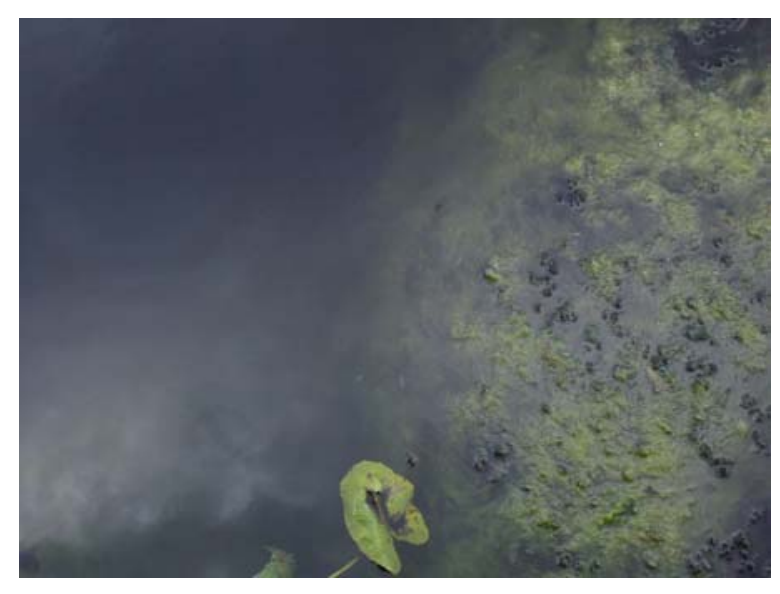

Esse é Bernardo. Bernardo da Mata. Apresento.

Ele faz encurtamento de águas.

Apanha um pouco de rio com as mãos e espreme nos vidros Até que as águas se ajoelhem

Do tamanho de uma lagarta nos vidros.

No falar com as águas as rãs o exercitam.

Tentou encolher o horizonte

No olho de um inseto - e obteve!

Prende o silêncio com fivela.

Até os caranguejos querem ele para chão.

Viu as formigas carreando na estrada duas pernas de ocaso para dentro de um oco... E deixou.

Essas formigas pensavam em seu olho.

É homem corrido de existências.

Estão favoráveis a ele os camaleões.

Espraiado na tarde -

Como a foz de um rio - Bernardo se inventa...

Lugarejos cobertos de limo o imitam.

Passarinhos aveludam seus cantos quando o vêem. 


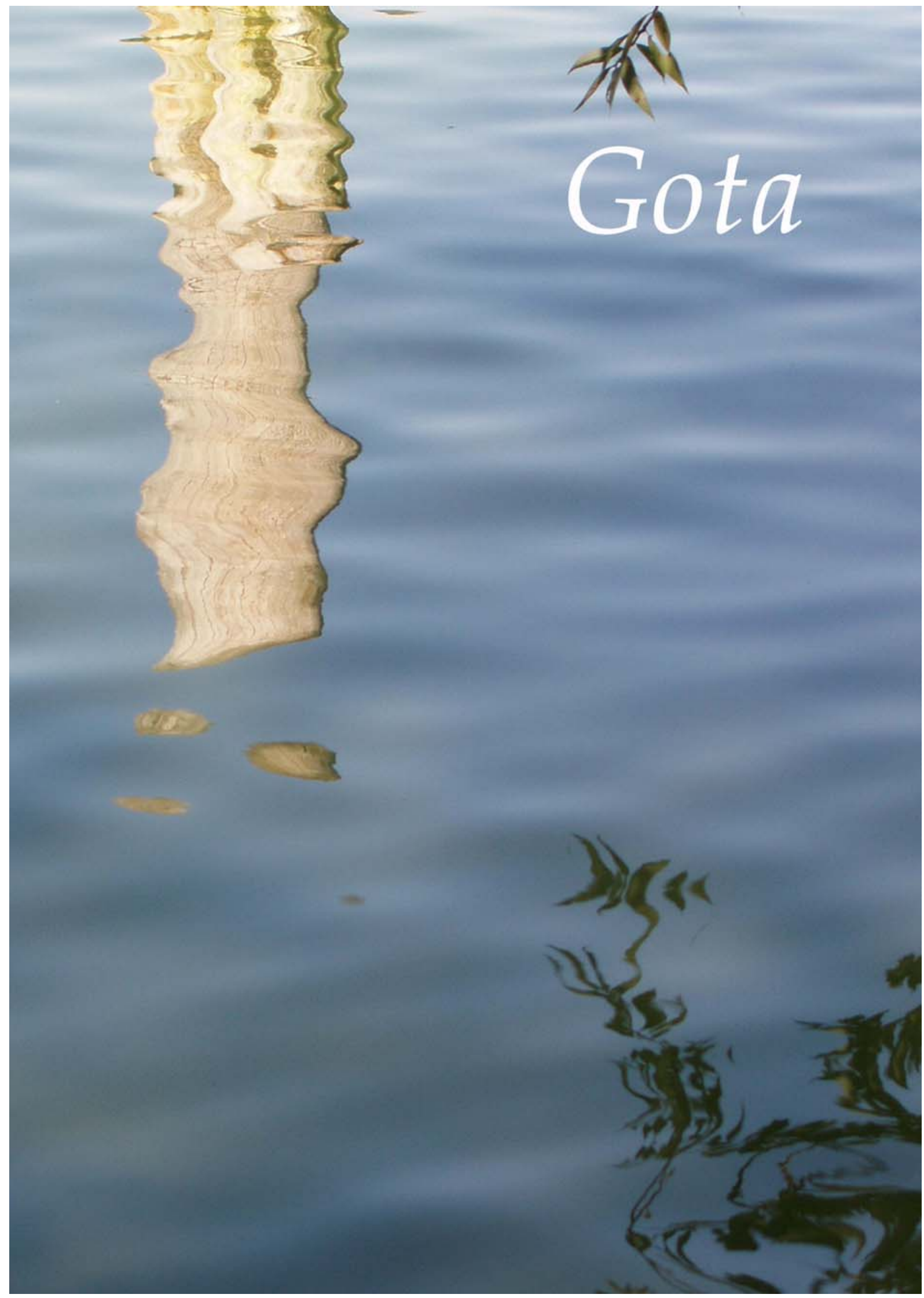




\section{Apresentação}

Nasci em uma pequena cidade cujo nome em tupi-guarani significa morada do sol. Talvez por ter vivido tão perto do sol e tão longe do mar, minha sede por água fosse desde cedo tão funda. As primeiras águas que conheci não foram as de rios ou de mares, mas as águas azulejadas das piscinas. Embora houvesse córregos em minha cidade, só os conheci mais tarde, onde já um pouco crescido brinquei com argila. As primeiras águas foram azulejadas. E encanadas. Já era uma natureza tomada pela cidade e disponível na ponta dos dedos, ao abrir das torneiras. Foram estas piscinas que envolveram meu corpo de menino, que já apreciava o incômodo do silêncio e o sabor da flutuação. Pouco a pouco, as piscinas transformaram-se em aquários, nesta época ainda com peixes, que eu passava horas a contemplar. Estes pequenos mundos, em que a comunicação se dava pelos movimentos e pelas imagens. Estes pequenos mundos, que envolviam seus integrantes sem isolá-los, fazendo-os tornar-se dependentes da água, como nós do ar. Cresci num bairro chamado Fonte. Mas não demorei tanto para conhecer o mar. Ainda pequeno passava as férias em Santos, e depois, adolescente, admirava o mar de Ubatuba, e já refletia, com as crises da idade, como um peixe fora d'água. Nunca fui muito de aprontar artes. Mas um dia aprontei. Pendurei uma mangueira d'água como uma cachoeira numa árvore do quintal e, com a liberdade de quem ainda não conhecia os críticos, enchi tudo de flores. Minha mãe, um pouco assustada com a arte, pediume explicações. Quais as explicações que se dão à arte?

E assim, água e arte seguiram juntas seu curso em meu caminho. No início foi o design gráfico, que exerci em meu escritório que não poderia ter outro nome senão Acquamundi. Mas então a água procurou suas frestas e não era mais possível fugir da arte. E aí vieram baldes, aquários, rios... Em São Paulo refleti sobre os horizontes e observei os peixes inexistentes do Tiête. Mas também garças em calçadas de concreto e capivaras teimosas. Recentemente caminhei por dois anos sobre as águas de Berlim. Atravessava diariamente a ponte do rio germânico, por onde passavam cisnes sob a luz da lua. E no inverno havia gelo e patinadores. Ainda posso sentir a fria brisa da primavera.

Agora trato de reunir esta água e encontrar seus possíveis vasos comunicantes. Não apenas através da reflexão de Narciso, mas tentando enxergar nas águas um pouco mais de profundidade. E também as imagens dos outros que caminham ao redor do mesmo lago. É claro que não será possível efetuar todos os mergulhos, mesmo que a sede seja grande. Quero olhar para a arte e para os olhos dos outros. Tentarei colocar a água em palavras. Mas quais as explicações que se dão à água? 
Começarei pela nascente, onde se encontram os mitos e os seres molhados, e também as histórias da criação do mundo. Neste caldo primeiro deste trabalho repousa parte da cultura da água, que nos serve de fonte para criação da arte. No segundo momento deste rio de palavras, passo a estudar as imagens que os artistas históricos fizeram da água. No terceiro capítulo a presença da água já atravessa tudo, como material integrante da arte contemporânea. Aqui olho para meus colegas e tento enxergar onde molham seus pés. Não poderei dar nome a todos, assim como não se contam todos os peixes que formam um cardume. No quarto momento desta caminhada, apresento-me e ofereço um pouco da água de meu copo. Mas espero não entregar todos os segredos. Apenas pretendo mostrar o traçado do rio. Quando se fala de arte, as palavras parecem poucas e não podem conter tudo o que corre solto. Assim as obras fluem ao lado das letras e às vezes preferem o silêncio para dizer mais. Por último convido para um mergulho nos fenômenos aquáticos e para um gole de sua significação. Não se contarão todas as moléculas do líquido, já que a todo momento elas fluem soltas e tendem a estabelecer novas relações. A piscina está aberta e cada um que dê o seu mergulho. É sempre difícil colocar a água em caixas e ela tende a escorrer, refletir e transparecer. Espero que seja possível ver através, testar a profundidade, saborear a superfície, mas sobretudo banhar-se... 


\section{Nascente}




\title{
1. Uma Introdução à história cultural da água
}

\author{
Eu me admiro do ferver da água e dos homens, \\ que juntos "queimam" e ainda assim vivem. \\ Zosimos de Panópolis. 390 d. C.
}

\begin{abstract}
No princípio criou Deus os céus e a terra.
A terra era sem forma e vazia; e havia trevas sobre a face do abismo, mas o Espírito de Deus pairava sobre a face das águas. Disse Deus: haja luz. E houve luz.

Viu Deus que a luz era boa; e fez separação entre a luz e as trevas. E Deus chamou à luz dia, e às trevas noite. E foi a tarde e a manhã, o dia primeiro.

E disse Deus: haja um firmamento no meio das águas, e haja separação entre águas e águas.

Fez, pois, Deus o firmamento, e separou as águas que estavam debaixo do firmamento das que estavam por cima do firmamento. E assim foi. Chamou Deus ao firmamento céu. E foi a tarde e a manhã, $o$ dia segundo.

E disse Deus: Ajuntem-se num só lugar as águas que estão debaixo do céu, e apareça o elemento seco. E assim foi.

Chamou Deus ao elemento seco terra, e ao ajuntamento das águas mares. Eviu Deus que isso era bom.

Pensar sobre a água no contexto da arte não é como desenvolver um trabalho sobre outro material qualquer, mas exige uma reflexão sobre a história e a significação cultural deste elemento primordial no desenvolvimento da civilização. A água é sabidamente um dos elementos mais necessários para a vida do homem e determina grande parte de seus hábitos, influindo em aspectos de sua vida individual e coletiva. A busca por água e a tentativa de dominá-la e colocá-la à disposição dos homens levam ao desencadeamento de processos políticos, sociais, tecnológicos e culturais. A água é estudada nos mais variados campos, como a física, a química, a biologia, a medicina, a nutrição, a ecologia, a higiene e o saneamento urbano, os transportes, as técnicas de guerra e de navegação, a agronomia, a arquitetura e a engenharia, a economia, os estudos culturais, os esportes, as religiões e as teorias esotéricas.

Hartmut Böhme, autor de "Kulturgeschichte des Wassers"1 (História cultural da água) e de diversos artigos sobre o tema, apresenta um interessante parágrafo que exemplifica esta variedade de aproximações possíveis do tema água. "não bebemos simplesmente água, mas tomamos um gole que aproxima os lábios, enche a boca, escorre pela garganta e cai no estômago - isto é água no esquema fisiológico do movimento do beber; ela nos parece suave, doce, ácida, estagnada ou borbulhante 
- isto é água no esquema do paladar; bebemos com avidez, gole por gole, como acompanhamento da comida ou alternando-a com o vinho - isto é água no esquema da sede e dos hábitos do beber; bebemos em Berlim, de uma garrafa que foi enchida em Auvergne com água das profundezas das formações vulcânicas - isto é água como produto industrial com selo de qualidade de altíssima pureza natural; bebemos, porque lemos a análise hidrológica na etiqueta - isto é água como objeto de análise química; bebemos por causa de sua constituição mineral - isto é água no esquema da nutrição; bebemos de uma garrafa de vidro, não de plástico - isto é água no esquema da consciência ecológica; pagamos mais por esta água - isto é água no esquema do valor do dinheiro, que é determinado por diversos fatores: custos de produção, transporte e distribuição, localização dos mercados, prestígio da marca, consciência do consumidor, hábitos de consumo." ${ }^{2}$

Se, por um lado, na sociedade contemporânea o homem conquistou uma série de procedimentos que facilitam a obtenção de água e muitas vezes o afastam da percepção do ambiente onde a água é coletada, por outro lado, a natureza mostra seu poder incontrolável através de tempestades, tsunamis e maremotos, ou através de secas arrasadoras. Quando bebemos um copo d'água atualmente, dificilmente imaginamos qual a estrutura de canalização e tratamento desta água, qual sua origem e as dificuldades vencidas para que ela chegue a nossa casa. O contato com a água, que em tempos antigos exigia uma série de esforços e salientava a dependência do homem da natureza, hoje parece estar quase "desnaturalizado", realizando-se automaticamente no simples ato de abrirmos a torneira.

Em ambiente macro-político a luta pela água e com a água é um dos grandes problemas contemporâneos. Como exemplos recentes pode-se citar a polêmica do desvio do curso do rio São Francisco, o recapeamento das margens e o tratamento da água do rio Tietê, em São Paulo, além da disputa pela água na região conflituosa de Israel e da Palestina ou mesmo as dificuldades apresentadas pelo Tsunami na Indonésia e países vizinhos em 2004 e pelas enchentes ocasionadas por furacões em New Orleans e em outros locais. Uma das maiores preocupações dos cientistas atualmente é o derretimento das geleiras, que poderia criar um imenso aumento dos oceanos, provocando inundações e submergindo grandes áreas de terra. Entretanto a falta de água ainda castiga. Recentemente pôde-se observar as secas no Rio Amazonas, que mataram milhares de peixes ou o envenenamento das águas do rio Songhua na China, que provocou a falta de água para milhares de pessoas.

Cerca de $70 \%$ da superfície da terra é coberta por água e nosso corpo também compõe-se de água aproximadamente nas mesmas proporções. ${ }^{3} \mathrm{Em}$ alguns frutos e vegetais esta composição chega a $90 \%$ ou mais. A água está presente na 
alimentação dos animais e do homem e também em seus processos de reprodução e desenvolvimento.

A ciência evolucionista admite a origem da vida a partir da água. Há milhões de anos a terra deveria ser coberta por uma camada de gases e vapor (atmosfera original), que consistia de metano, amoníaco, vapor e água. Violentas tempestades teriam preenchido as partes mais baixas da terra, formando os oceanos, onde iria se iniciar a vida. As matérias orgânicas existentes na antiga terra sofreram reações químicas ocasionadas pelas diversas fontes de energia disponíveis, como calor dos vulcões, descargas elétricas, radiação ultravioleta e deram origem aos aminoácidos, que são a base para o desenvolvimento das proteínas e também ao ácido nucléico (DNA e RNA - moléculas básicas para o desenvolvimento do aparato genético). O surgimento dos primeiros seres vivos deve ter ocorrido a partir da conexão de moléculas específicas existentes nesta "sopa" original. O desenvolvimento da vida segue ligado à água, surgindo primeiramente os animais aquáticos, e posteriormente os anfíbios, répteis, aves e mamíferos.

\section{1. Água e espírito}

A importante presença da água na formação do mundo e da vida é admitida não só pela ciência, mas faz parte de quase todas as cosmogonias de várias civilizações. No Alcorão, está escrito: "E Alá criou da água todos os animais e entre eles os répteis, os bípedes e os quadrúpedes. Alá cria o que lhe apraz, porque Alá é onipotente."(Sura 24, vers. 45).

No trecho inicial do gênesis, na Bíblia, está escrito que "o espírito de Deus flutuava sobre as águas". Note-se que "No princípio criou Deus os céus e a terra", e só depois a luz, o sol, as estrelas, plantas, animais e finalmente o homem. Wolfgang Detel ${ }^{4}$ comenta que, embora haja no desenvolvimento do texto da Bíblia referências à criação de todas as outras coisas, não há nenhuma referência direta a criação da água. Já no segundo versículo é dito que "o espírito de Deus flutuava sobre a água". A água, então, seria algo já pré-existente e original, sobre a qual o espírito de Deus flutuava. Pode-se considerar, então, que talvez a água, fosse uma parte do próprio Deus, e este estaria intimamente ligado à ela. No versículo 6 está escrito ainda que "disse Deus: haja um firmamento no meio das águas, e haja separação entre águas e águas." No próximo versículo é dito que Deus chamou este firmamento de céu e após ajuntarem-se as águas na parte debaixo do céu (mares), Deus chamou a parte seca de terra. Note-se que a partir desta parte indiferenciada e contínua que seria a água, Deus criou partes mais sólidas e definidas, como o céu e a terra. A palavra 
firmamento, que em português é quase sinônimo para céu, aproxima-se da palavra firme, que denota algo concreto e definido. Na versão alemã da Bíblia isto torna-se ainda mais claro, pois firmamento é traduzido como $F_{e s t e}{ }^{5}$, que em alemão é exatamente a palavra que significa fixo, concreto e definido. Assim, mesmo o céu, em sua amplidão etérea teria um caráter mais definido e fixo do que a natureza mutante e informe da água.

Wolfgang Detel ${ }^{6}$ conta que nos mitos do antigo oriente médio, como na cosmogonia babilônica Enuma Ělis também está escrito que no início havia apenas água, ainda não separada em água salgada e doce; posteriormente surgiram o Deus Apsu, que seria a água salgada, e a Deusa Tiamat, a água doce. A partir deste casal de Deuses formaram-se Ansar e Kisar, respectivamente céu e terra. A semelhança com o velho testamento é bastante grande e, provavelmente, este teria se baseado nestas antigas tradições.

A importância do elemento água no antigo testamento é verificada não apenas no Gênesis, mas também em várias outras passagens e pode ser explicada por diversos motivos. A terra dos judeus e dos primeiros cristãos localiza-se numa região em que a conquista da água teve papel fundamental. Os povos da antiga Mesopotâmia e do Egito tiveram o seu desenvolvimento garantido graças ao domínio dos rios Nilo, Tigre e Eufrates. Para os egípcios, o mais antigo dos Deuses era Nun, o oceano universal. Nun é também tido como o deus da criação e relacionado à origem do Nilo. A mitologia egípcia conta também a história do Deus Osíris, entidade ligada à ressurreição, à vegetação e ao mundo subterrâneo, cujo corpo teria sido despedaçado por seu irmão Seth e jogado no rio Nilo ${ }^{7}$. O Nilo, como local depositário do corpo de Osíris, é portanto ao mesmo tempo local da morte e do renascimento (o corpo de Osíris renasce após o reagrupamento de seus pedaços por Isis). Estes dois opostos são vivenciados pelos egípcios através das cheias e das secas do grande rio.

Em alguns mitos gregos, a presença da água aparece novamente como o elemento original. Na llíada, Homero afirma que Okeanos (o oceano) é o ventre para o desenvolvimento de todas as coisas. Para o primeiro filósofo grego, Thales de Mileto(624-546 a.C.), a água seria o elemento original ou o princípio de todas as coisas. Embora não tenham restado escritos originais de Thales, este seu ensinamento é relatado por Aristóteles em sua "Metafísica". Thales também foi autor de uma teoria sobre as cheias do Nilo e de diversos teoremas matemáticos. Thales, que viveu na cidade portuária de Mileto e realizou diversas viagens nos arredores do oriente médio, provavelmente teve acesso a estas antigas tradições orientais e foi bastante influenciado por elas. ${ }^{8}$ 
No estudo dos elementos desenvolvido pelo filósofo grego Empédocles (495 - 435 a. C.), a água, juntamente com o fogo, o ar e a terra, era um dos quatro elementos constituinte de todos os seres e todas as outras matérias. Este estudo dos quatro elementos influencia a filosofia medieval, que acreditava que o temperamento do homem era regido por estes elementos. Gaston Bachelard afirma que, segundo a visão epistemológica medieval, os homens estariam divididos em quatro humores ou temperamentos básicos que seriam associados a quatro matérias líquidas presentes no corpo humano: sangue, fleuma ${ }^{9}$, bílis negra e bílis amarela. O sangue era associado ao temperamento dos "sanguíneos, que são regidos pelo elemento ar e cujos sonhos são vôos de pássaros, de corridas e de festins. Os biliosos ou coléricos são regidos pela bílis amarela e estão associados ao fogo, e seus sonhos são de incêndios, de guerras e de assassinatos. Os melancólicos são regidos pela bílis negra, associam-se à terra, e seus sonhos são de enterros, de sepulcros, de fugas e de tudo que é triste. Os pituitosos ou fleumáticos são regidos pela fleuma, associados à água e seus sonhos são relacionados a inundações, lagos, rios e naufrágios. ${ }^{10}$ É interessante ressaltar, que mesmo os temperamentos relacionados aos outros elementos, seriam regidos uma matéria líquida do corpo. Embora esta concepção não seja mais adotada pela psicologia atual, o estudo dos elementos fundamentais ainda encontra eco hoje na definição dos elementos dos signos do zodíaco.

A água, não é apenas o elemento primordial nos mitos de criação e na definição dos temperamentos, mas incorpora também elementos de destruição e transformação em sua simbologia. No episódio bíblico do dilúvio, por exemplo, é a ira da destruição divina que é manifestada pela água. O surgimento do arco-íris, ao final do dilúvio, representa, por sua vez, a reconciliação de Deus com os homens, e pode ser assim tomado como um símbolo para a própria religião. O arco-íris pode ser interpretado como um elemento intermediário entre o céu e a terra, em que a água está em associação com a luz. A iconografia do arco-íris é diversas vezes utilizada nas imagens cristãs medievais e renascentistas, e aparece também posteriormente nos quadros de pintores românticos.

$\mathrm{Na}$ liturgia cristã pode-se citar ainda inúmeras outras passagens em que água tem um papel fundamental, como por exemplo: a abertura do mar Vermelho, o sacramento do batismo, a transformação de água em vinho, o caminhar de Cristo sobre as águas, a lavagem dos pés dos apóstolos por Cristo, o "lavar as mãos" de Pilatos, etc. $\mathrm{Na}$ abertura do mar Vermelho observa-se simultaneamente o caráter de vida e morte ligado à água. Se a abertura do mar vermelho representou a salvação e a vida para o povo de Moisés, ela é ao mesmo tempo a representação da morte para seus perseguidores que se afogam. 
A transformação da água em vinho reforça o seu caráter espiritual e remete ao seu poder enquanto elemento transmutador. O poder transformador da água é reconhecido também pela alquimia. Hans-Werner Schütt relata-nos sobre um texto no qual o importante alquimista Zosimos de Panopolis (cerca de 390 d.C.) conta um de seus sonhos no qual a água desempenha o papel principal. No sonho, Zosimos encontra-se diante de um altar no qual vê uma tigela com água fervendo, e dentro dela várias pessoas. Não entendendo o que acontece, Zosimos se dirige a um "homunculus"11 presente no local e diz: "Eu me admiro do ferver da água e dos homens, que juntos 'queimam' e ainda assim vivem"12. O homunculus então explica-lhe, que tal ritual trata-se de uma transformação (Wandlung ${ }^{13}$ ), em que os homens perdem seu corpo para se tornarem espíritos. A água teria portanto um papel transmutador e é equiparada ao próprio espírito. Segundo Schütt, muitas vezes os alquimistas fazem referência em seus escritos a uma certa água da transformação (ou da consagração), chamada Theia hydrata. Esta substância denominaria uma certa matéria líquida presente em todos metais, que seria responsável pela sua capacidade de derretimento e também pela sua cor, podendo tingi-los ou dissolvê-los. Mesmo que muitas vezes esta substância não fosse verdadeiramente água, mas algum sulfito, ela é descrita como água pelos alquimistas. Segundo Schütt, a palavra Theia advém de theion, que em grego pode significar ao mesmo tempo divino ou sulfúrico. De qualquer forma, também aqui se verifica a associação entre a água e o divino.

\subsection{Corpo e purificação}

Ao longo da história diversos são os rituais nos quais a água é utilizada como elemento de purificação. Altares, pias batismais, banheiras, rios e mares são os locais onde estes rituais se realizam.

Um dos exemplos mais antigos destes altares místicos, ainda existente até hoje, é a grande "banheira" assíria em exposição no Pergamon Museum de Berlim. Nesta peça esculpida em pedra, vêem-se sacerdotes cujo corpo é coberto com uma capa representando peixes. No centro da peça vêem se ainda correntes de água que vêm do céu e terminam na terra. Esta banheira datada de 704-681 a.C. , era provavelmente utilizada para rituais de purificação. A imagem do peixe, que aparece aqui em destaque, seria também posteriormente utilizada como símbolo do povo cristão durante o império romano. 


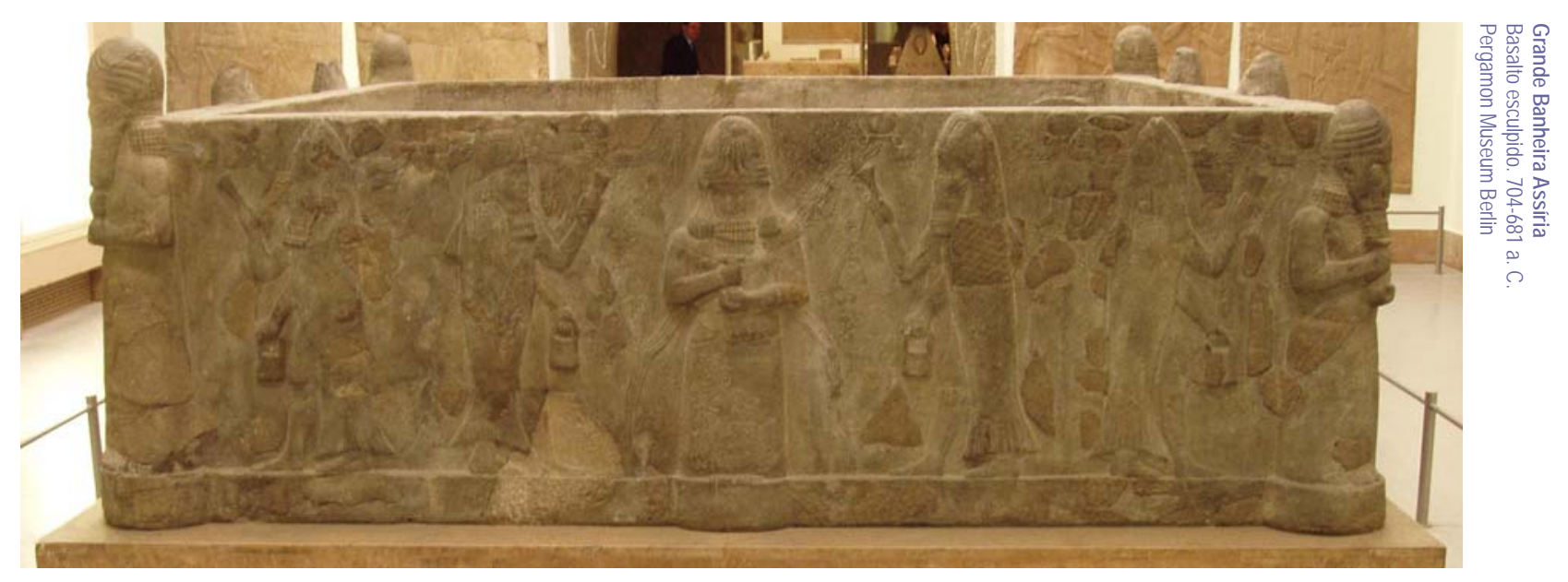

$\mathrm{Na}$ igreja católica e na maior parte das correntes protestantes, o batismo é um dos sacramentos principais. Este ritual é diferentemente realizado por cada corrente, podendo ser em uma pia bastimal ou mesmo em rios. $\mathrm{O}$ batismo, para as religiões cristãs, representa um renascimento, ou o verdadeiro começo da vida. $\mathrm{Na}$ igreja católica costuma-se colocar vasilhas com água benta que pode ser utilizada pelos fiéis.

Nas comunidades judaicas ortodoxas é comum a existência de uma banheira especial (Mikwe) construída geralmente abaixo do nível da terra, na qual as mulheres devem se banhar após a menstruação, na véspera do casamento e em outras ocasiões. Segundo o Talmude, originalmente deveriam também os homens se banhar, mas posteriormente esta tradição foi sendo mais utilizada pelas mulheres. A Mikwe também pode ser utilizada para purificar-se após o contato com um cadáver, na cerimônia de conversão para o judaísmo e em outras situações.

Entre os muçulmanos são previstas abluções para a purificação antes das orações e deveres religiosos. A ablução maior é lavar todo o corpo por ocasião das relações sexuais, menstruação, contato com um cadáver, a fim de se livrar das impurezas. Esta ablução também é indispensável para ingressar na Mesquita, lugar consagrado, ou manusear o Alcorão. A ablução menor é utilizada para a limpeza decorrente das funções corporais, ou perda da consciência momentânea, por exemplo, o sono. Exige-se que partes do corpo, como os pés, o rosto, as mãos sejam lavadas nas dependências próximas das Mesquitas. Caso não haja água disponível, as abluções podem ser feitas com areia ou terra.

Nos cultos de origem afro-brasileira a água aparece com bastante importância. São conhecidos os banhos (com sal grosso, rosas ou ervas) receitados para se livrar de más energias. A lavagem das escadarias da igreja do Nosso Senhor do Bonfim, que também tem o sentido da purificação, já ultrapassou o simples caráter religioso, tornando-se até importante chamariz turístico da Bahia. 
Para os espíritas kardecistas, é comum a colocação de um copo de água durante as orações e o recebimento dos espíritos de luz para que esta água seja magnetizada por seus fluidos. A água deve ser bebida posteriormente como benção e remédio espiritual.

O sentido da purificação presente na água supera os limites dos ritos culturais. Ele tem sua origem no próprio contato fenomenológico com a água e as projeções do ideal de pureza existente no homem. Para Bachelard, "não se pode depositar o ideal de pureza em qualquer lugar, em qualquer matéria. Por mais poderosos que sejam os ritos de purificação, é normal que eles se dirijam a uma matéria capaz de simbolizá-los. A água clara é uma tentação constante para o simbolismo fácil da pureza. Cada homem encontra sem guia, sem convenção social, essa imagem natural". ${ }^{14} \mathrm{~A}$ imaginação material da pureza da água, localiza-se em sua própria essência e, segundo Bachelard, independe da transmissão de "formas" culturais, mas nasce da vivência direta do homem com a matéria. As diferentes manifestações culturais nas quais a pureza da água é referida são o resultado de uma concretização social e coletiva da experiência fenomenológica individual do homem com a água.

$\mathrm{Na}$ sociedade atual muitas das narrativas mitológicas e das tradições religiosas e ritualísticas perderam sua força em virtude da urbanização, do aumento do individualismo, da globalização e das exigências da vida prática contemporânea. Entretanto, mesmo o homem que não está ligado a religiões ou desconhece seus fundamentos já incorporou a sua vida hábitos e sentidos sociais que se relacionam com certos rituais originais, ainda que inconscientemente. Os rituais de purificação e a crença no poder curativo da água, por exemplo, chegam até nossos dias em hábitos sociais que não se relacionam obrigatoriamente a procedimentos religiosos, mas representam muitas vezes símbolos de status ou de convívio social. Se para as culturas judaica e muçulmana, por exemplo, a noiva deveria banhar-se antes do casamento para purificar-se, hoje em dia é cada vez mais comum a existência do "dia da noiva" organizado por spas e empresas que oferecem banhos especiais com sais e ervas, além de massagens e técnicas de relaxamento. Da mesma forma, são conhecidos também os banhos e as águas minerais das chamadas "estações de águas", como as cidades de Lindóia, Poços de Caldas, São Pedro, Pousadas do Rio Quente e outras. É comum a presença de idosos ou de casais com crianças nestes locais, na busca de repouso e até mesmo de rejuvenescimento. A freqüência a piscinas e praias é outro hábito contemporâneo bastante apreciado, que além de fazer parte da cultura de culto à saúde corporal, apresenta também um componente da sensualidade. Todos estes hábitos ultrapassam a simples busca objetiva de saúde, tornando-se rituais de integração e convívio social. Se na cultura ocidental 
contemporânea o discurso religioso regulador das atividades práticas e morais do homem perdeu seu poder hegemônico de outrora, muitos dos hábitos da lida do homem com a água, fundamentados antigamente em preceitos da fé, ganham hoje uma nova roupagem, que se baseia freqüentemente nos discursos do culto ao corpo, do lazer e do turismo, da psicolgia, da ciência e ou de correntes esótericas não vinculadas à religião.

O contato corporal com a água é portanto receptor de significados que ultrapassam as simples necessidades de higiene. Até mesmo a concepção de higiene sofre alterações no decorrer da história. Em "O limpo e o sujo: uma história da higiene corporal", de Georges Vigarello ${ }^{15}$ aprende-se que entre os séculos XV e XVII existiu um declínio constante do uso dos banhos e da higiene com água. No século XV ainda era relativamente comum a visita a banhos públicos, que embora não fossem freqüentes, tinham uma conotação mais ligada ao prazer do que propriamente à higiene, servindo muitas vezes como locais para encontros sexuais. Com o avanço da peste e a crença de que a água pudesse penetrar na pele e contribuir para a transmissão de doenças, o banho é cada vez menos utilizado, sendo substituído por uma higiene que valoriza as aparências e destaca o uso de roupas brancas, justas e impermeáveis. Só a partir do século XVIII é que o hábito de banhar-se é lentamente recuperado e os castelos começam a ser equipados com banheiros apropriados. Nos meados do século XVIII, os banhos ainda tem um caráter quase cerimonial e público, denotando o status do banhista. No decorrer da história a higiene vai se tornando um assunto cada vez mais privado e íntimo, ao mesmo tempo que o uso do banho torna-se diário.

Conclui-se portanto que as relações entre o corpo e a água espelham os comportamentos sociais históricos e as convicções religiosas do homem. O conjunto de hábitos e concepções do homem sobre a água serão também retratados pela arte de acordo com a visão epistemológica de sua época. Assim nota-se por exemplo um aumento no interesse da representação de banhistas a partir do século $\mathrm{XIX}$, como em quadros de Ingres, ou posteriormente em alguns impressionistas (Degas, Lautrec, Bonnard) e até mesmo em Picasso. Na arte contemporânea este interesse é retomado de nova maneira, como por exemplo nos quadros de Hockney. Posteriormente discutirei com mais detalhe as relações entre corpo e água na arte. 


\section{3. Água e mito}

Diversas são as criaturas simbólicas relacionadas à água. Desde os mitos gregos e romanos até as manifestações folclóricas incluem seres mágicos e poderosos ligados ao elemento aquático. A imaginação de um ser mítico que encarna determinados poderes e elementos ou que vivencia determinadas situações fantásticas é um procedimento comum na antiguidade; muitos destes personagens, entretanto, atravessam os séculos como espécies de arquétipos representativos de certas atitudes e temperamentos, e são constantemente revividos pela história da arte. Determinados períodos artísticos, como por exemplo o romantismo e o simbolismo, demonstraram especial interesse por este tipo de figuração alegórica. Mesmo em um tempo descrente como o nosso pode-se encontrar exemplos na arte contemporânea que fazem referência a tais mitologias, procurando reinventá-las ou pelo menos utilizá-las como um pastiche midiática pós-moderna. Alguns exemplos destes procedimentos serão apresentados nos próximos capítulos deste trabalho.

Entre os mitos e personagens relacionados à água mais conhecidos estão Netuno, Narciso, as Sereias e a personagem Ophelia, de Shakespeare. O conhecido deus grego dos mares Poseidon (Netuno, para os romanos) era um dos irmãos diretos de Zeus, filho de Chronos e Rhea. Geralmente é representado com um tridente e é levado por uma carruagem puxada por cavalos marinhos ou hipopótamos. Poseidon era tido como o senhor da ilha de Atlântida e responsável pelos maremotos, terremotos e tempestades. Netuno é ainda hoje uma figura razoalmente popular, tendo sido retratado inclusive em desenhos animados e histórias em quadrinhos. Ao longo da história da arte foi repetidamente representado, tanto em pinturas como em esculturas, sendo muito comum encontrar estátuas suas em fontes e jardins aquáticos, como na Fontana di Trevi, em Roma e na Neptunbrunnen em Berlim. A principal conotação da água na lenda de Netuno é novamente o duplo sentido como fonte de vida versus poder destrutivo.

Um personagem ligado à água ainda bastante conhecido em nosso tempo é Narciso. Este belo jovem era filho do deus-rio Cefiso e da ninfa Liríope. Quando nasceu, o adivinho Tirésias disse que Narciso poderia viver muito, desde que nunca visualizasse sua própria imagem. Narciso era um rapaz vaidoso, que atraía a atenção de moças e rapazes, mas desprezava ambos. A ninfa Eco foi uma das que se apaixonou por ele, sem ser correspondida. Um certo dia, Narciso observou o próprio rosto nas águas e apaixonou-se por sua própria

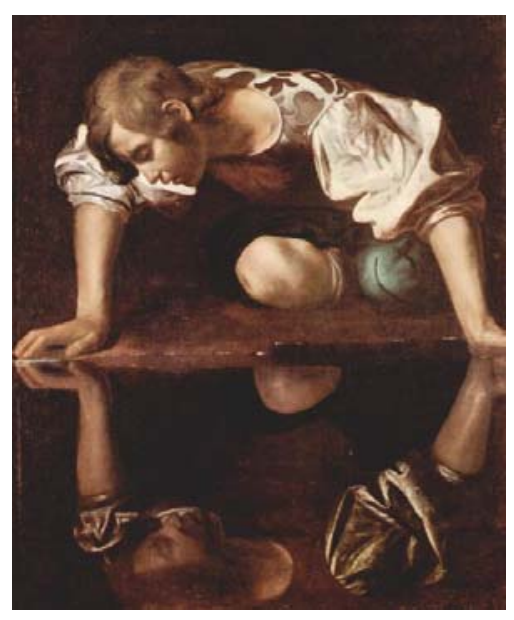


imagem. Segundo algumas versões, Narciso teria ficado ali até se consumir, morrendo de inanição. Outras histórias contam que ele teria se atirado às águas, ou então, que o rosto que ele teria visto nas águas, não seria o seu próprio, mas o de sua irmã gêmea, por quem era apaixonado. No local onde Narciso morreu, nasceu a flor Narciso. A associação erótica presente na lenda de Narciso, ressalta o componente de sensualidade relacionado à água. A água e sua relação com o corpo e a beleza ganham destaque nesta lenda.

A lenda de Narciso tornou-se especialmente conhecida para o público contemporâneo gracas a interpretação psicológica de Freud, que cunhou o termo Narcisismo. O Narcisismo seria uma espécie de comportamento psicológico, em que o indivíduo não consegue voltar a sua libido ao mundo que o cerca, ficando preso a uma admiração de si mesmo. Ao longo da história, diversos outros psicólogos contribuiram e discutiram o Narcisismo, considerado para alguns como algo positivo para o desenvolvimento infantil da personalidade até uma certa idade, porém como neurótico quando exagerado na idade adulta. O Narcisismo também foi muito relacionado pelo senso comum ao comportamento dos artistas, que foram muitas vezes acusados de viver em um mundo próprio, distante da realidade.

A água tem papel fundamental na lenda de Narciso pois é ela que aparece como responsável por um espelhamento do mundo, criando um outro mundo virtual e fantasioso. As antigas lendas da origem da arte atribuem a Narciso invenção metafórica da pintura. Este fato é mencionado por Alberti no tratado Della Pittura ${ }^{16}$. A superfície da água seria portanto a primeira tela, refletindo a representação do mundo. A questão do espelhamento do mundo e da representação é uma das questões mais discutidas pelas teorias da arte em toda a história. No caso das obras que representam ou utilizam a água em sua constituição, que são o tema deste trabalho, esta questão apresenta complicações e características específicas fundamentais, que discutirei no capítulo 5 deste trabalho. Entre os diversos artistas que retrataram Narciso, uma das imagens mais conhecidas é a pintada por Caravaggio.

Outra criatura mitológica aquática oriunda da antiguidade são as sereias. Em sua origem, as sereias seriam filhas do rio Achelous com a musa Terpsícore. Estes seres metade peixe metade mulher, encantariam os homens com seu lindo canto, que seriam arrastados para as águas, na maior parte das vezes afogando-se. As sereias reaparecem ao longo da história com diversos outros nomes e variações, como ondinas ou melusinas. No folclore brasileiro, pode-se citar Yara e Janaína. Também entre as ninfas, que são seres femininos ligados à natureza, habitando bosques, montanhas e riachos, pode-se destacar aquelas que são ligadas especificamente à água: as oceânidas (ligadas à água salgada), as nereidas (ligadas ao mar 
mediterraneo), as naiádes (ligadas a água doce), as crináias (ligadas a fontes), as potâmides (ligadas a rios) e as liminátides(ligadas a lagos perigosos e pântanos).

O candomblé também reúne uma série de orixás de sexo feminino relacionados à água. Iemanjá, a Grande Mãe e vaidosa rainha do mar, é uma das entidades mais adoradas e conhecidas do povo brasileiro, à qual são feitas oferendas na virada do ano. Além de lemanjá, são também ligadas à água Oxum (orixá das águas doces, do ouro, do amor e da fertilidade) e Obá (orixá da água, do trabalho doméstico e do poder da mulher).

Não só as narrativas religiosas e míticas apresentam personagens femininos relacionados à água. Também na literatura encontram-se exemplos. Um dos personagens femininos mais famosos ligados à água e retratados pela história da arte é Ophelia do texto dramático "Hamlet" de Shakespeare. Ophelia era uma bela jovem apaixonada por Hamlet. Devido a suas dúvidas existenciais e à preocupação sobre quem teria matado seu pai, Hamlet dá pouca atenção a Ophelia, que enlouquece de amor. Um certo dia, Ophelia, que vagava pelo reino declamando poemas de amor, sobe em um salgueiro à beira do rio, cujo galho se quebra levando-a cair na água e afogar-se. Sem perceber, Ophelia ainda flutua enquanto recita versos apaixonados, até ser totalmente tragada pelo rio.

Para Bachelard, Ophelia representa a morte desejada na água. Embora não haja propriamente uma referência ao suicídio na peça de Shakespeare, Ophelia é interpretada como uma personagem que busca a morte, e que "nasceu para morrer nas águas". A sedução das águas e a vontade de dissolver-se totalmente no líquido é o que a atrai. Ophelia é também um personagem lírico imaginado, que se concretiza no mundo poético da fantasia. Sua morte não é a morte real de um afogado, mas é uma morte bela e idealizada, de um sofrimento lento de uma alma apaixonada e enlouquecida, e não apenas de um debater-se corporal. Esta condição idealizada e poética de Ophelia torna-a uma personagem adorada pela arte e pela literatura. Ophelia é figura constantemente retratada na história da arte, especialmente no século 19 , destacando-se os quadros dos pré-rafaelitas Millais e Waterhouse. Na literatura, também foi retomada diversas vezes, por autores como Rimbaud, Mallarmé e outros.

Tanto Ophelia, como as Sereias e Ondinas são personagem de uma feminilidade exaltada, ao mesmo tempo frágeis e sedutoras. A relação entre água e feminilidade é freqüentemente destacada por vários autores. A fertilidade, a sensualidade, a flexibilidade e a instabilidade são atributos geralmente relacionados à mulher $\mathrm{e}$ também presentes no elemento aquático. A umidade do sexo feminino necessária nos processos de sedução também pode ser associada à água. Mergulhar na água, 
ser envolvido por ela, senti-la por todo o corpo assemelha-se a estar contido no ventre da mãe. O leite materno é visto pela psicologia como uma primeira água original. A água é uma espécie de mãe universal dos seres, dando-lhes alimento e envolvendo-os e possibilitando-Ihes a vida.

\section{4. Água e técnica}

A conquista técnica da água e sua dominação sempre foram de fundamental importância para o homem. A invenção dos aqüedutos para transporte da água foi determinante no desenvolvimento dos povos. Embora já existentes de maneira precária nas civilizações pré-românicas, cabe aos romanos o seu aperfeiçoamento técnico e sua popularização. Um dos aqüedutos romanos mais conhecidos é o Aqua Virgo, na cidade de Roma, ao final do qual está instalada a famosa Fontana di Trevi. A fonte original, que existia na época dos romanos foi destruída no final da idade antiga, mas no renascimento retomou-se o interesse pela reconstrução. Inicialmente, em 1453, foi construída uma simples pia desenhada por Leon Battista Alberti. Após uma série de projetos desenvolvidos ao longo dos séculos, entre eles um desevolvido por Bernini, foi finalmente realizado o projeto de Nicola Salvi a partir de 1730. Posteriormente a fonte recebeu alterações, acréscimos e restaurações realizados por outros artistas.

A história da Fontana di Trevi ilustra os diversos aspectos na busca pela obtenção da água. Se as fontes inicialmente tinham como principal objetivo fornecer água à população, elas ganham conotações simbólicas ao longo da história da arquitetura e do urbanismo, tornando-se, ao mesmo tempo, pontos de encontro e lazer social e representação encenada de poder. Embora as fontes existam desde a antigüidade, é principalmente a partir do Renascimento que alcançam um grande destaque, tendo seu auge no período Barroco. A história das fontes, que se desenvolve em conjunto com a história da jardinagem, marca o traçado dos castelos e das cidades, regulando as relações sociais e afirmando o status dos governantes. 0 desenvolvimento das fontes reúne toda uma tecnologia e um vocabulário plástico próprio. Os tipos de fontes existentes vão desde simples pias e cubas, passando pelas fontes de parede ou nichos, chafarizes, cascatas e grutas artificiais, e chegando até fontes arquitetônicas e monumentais, que movimentam mecanismos ou encenam "coreografias" aquáticas.

O estudo da evolução das fontes, embora se relacione a algumas das obras que serão aqui examinadas, não é o objetivo principal deste trabalho. Sua história encontra pontos de contato com a história da arte, porém possui também o seu desenvolvimento próprio, baseado em preceitos da arquitetura, jardinagem, 
tecnologia e história social. A utilização da água na arte contemporânea não pode ser entendida como uma continuidade e desenvolvimento direto da história das fontes, mas encontra o seu berço no interior da própria arte, e das rupturas instituídas pelos artistas contemporâneos com a introdução de materiais e procedimentos até então incomuns a partir da segunda metade do século vinte.

O que me interessa ressaltar aqui é a influência do manejo da água no desenvolvimento técnico e social, e as consequências de sua percepção simbólica na vida do homem. A relação entre técnica e água não se restringe aos aqüedutos e fontes, mas engloba também, o desenvolvimento trazido, por exemplo, pelos avanços nas navegações, pela construção de diques e de técnicas de irrigação ou pelo saneamento básico.

É sabida a importância das navegações para o desenvolvimento cultural, comercial e social do mundo na época do renascimento. Os povos capazes de utilizar a água como meio de transporte, como os portugueses, espanhóis, ingleses, holandeses e italianos, por exemplo, foram os que dominaram a maior parte da economia mundial do renascimento. As cidades portuárias funcionaram como pólos comerciais e culturais, como é o caso de Veneza ou de diversas cidades holandesas. O saneamento básico, por sua vez, teve um papel fundamental para a cura de doenças e o desenvolvimento das sociedades, principalmente após as reformas higienistas do final do século XIX e início do século XX.

Hoje, apesar das diferenças culturais e sociais ainda existentes, temos em geral um ambiente em que relação do homem com a água apresenta bastante avanços em relação ao passado, porém ainda há muito o que se fazer. A relação entre o homem e a água fundamenta e regulamenta nosso convívio social. As grandes dificuldades do domínio da água foram atualmente praticamente esquecidos e a água parece estar disponível como que magicamente em nossas casas. A paisagem original na qual a água se situava e deslocava, foi substituída por uma urbanidade construída e tecnicizada. A percepção destas alterações não é clara e imediata ao homem contemporâneo, que nem sempre reflete sobre as condições determinantes da aparência do mundo em que habita. É a partir desta nova relação do homem com a água e com o mundo que o cerca, que é criada arte contemporânea, que é tema deste trabalho. Certamente, as relações existentes neste novo ambiente contemporâneo, acrescentadas de seu desenvolvimento histórico, impregnam definitivamente a arte produzida na atualidade. 


\subsection{Um imaginário aquático}

As diversas conotações simbólicas da água, apresentadas neste capítulo, formam uma espécie de imaginário aquático do qual os artistas irão se servir no decorrer dos séculos, ampliando-o e reelaborando-o através de suas experiências e interpretações poéticas. A simbologia da água tem sua origem tanto na experimentação individual fenomenológica da água, como na sua elaboração e transmissão social. Os usos e hábitos dos diferentes povos marcaram de maneiras específicas a relação do homem com a água, levando-o a desenvolver narrativas que dêem conta de descrever toda a sorte de sensações e anseios decorrentes desta relação. A complexidade da relação homem-água desdobra-se nos variados aspectos, de forma que as histórias sobre a água não são apenas a descrição de eventos reais, mas ganham tonalidades metafóricas que servem para explicar diversos dos comportamentos humanos. Assim, quando falo sobre água, não estou necessariamente querendo dizer apenas sobre a água em si, mas sobre toda uma sorte de significados que a água materializa.

As visões epistemológicas das sociedades e os seus diferentes estágios de desenvolvimento histórico determinam as diferentes nuances da narrativa da água. Esta grande narrativa é, por sua vez, composta por diferentes discursos que se entrelaçam, como as religiões, a ciência e a tecnologia, a psicologia e filosofia, a cultura e as artes. Em determinados períodos e discursos, há uma predileção pela simbolização alegórica da água, representada por seus personagens e mitos. Outros já são marcados por um enfoque aparentemente mais objetivo, baseando-se na observação da água enquanto fenômeno. É esta variação de nuances, e em especial as complicações trazidas pela utilização da água como matéria na arte contemporânea, que este trabalho pretende estudar.

Como discuti até aqui, nota-se que as conotações da água ligam-se muitas vezes a simbolizações da vida e da morte, da sensualidade e do espírito, da admiração e do temor. Acredito que tais simbolizações podem ser relacionadas também a propriedades físicas materiais da água e que a arte baseia-se tanto nestas conotações simbólicas culturais como em sua experimentação fenomenológica com a matéria. A introdução da água como material da arte contemporânea torna a percepção desta questão mais clara, já que a água aparece nestas obras como uma matéria em si, e não apenas como imagem simbólica. A discussão desta questão é um dos pontos principais deste trabalho, e será melhor esclarecida em seu desenvolvimento. 
Não só as artes plásticas refletem e interpretam a relação do homem com a água. Também as outras artes e manifestações culturais ocupam-se dela. A lista de exemplos de obras em que a água tem um papel fundamental é imensa e seu estudo demandaria o desenvolvimento de uma outra pesquisa. Posso porém mencionar alguns exemplos conhecidos. Na música clássica destacam-se composições de Haendel (Wassermusik) e Debussy (La Mer) e Poulenc; na música popular brasileira são inúmeros os compositores e intérpretes que cantam o mar e os rios, entre eles Dorival Caymi, Tom Jobim, Maria Bethania, Ivan Lins, etc.

Na dança contemporânea vale lembrar os trabalhos de Pina Bausch, Susanne Link e Sascha Walz, entre outros. No cinema pode-se citar desde o Encouraçado Potenkim, até 20 mil léguas submarinas ou Titanic; no cinema nacional não se pode esquecer de "Limite" de Mário Peixoto. Na arquitetura, além de toda a história do desenvolvimento das fontes, de Veneza e dos famosos diques holandeses, pode-se destacar na modernidade a famosa construção da casa "Waterfalls", construída por Frank Lloyd Wright, que se tornou um marco da arquitetura do século XX. Certamente o leitor deste trabalho irá se lembrar de muitos outros exemplos; não pretendo alongar-me mais nesta enumeração, que poderia dar origem a outras pesquisas.

Quanto ao desenvolvimento do estudo das poéticas da água nas artes plásticas, em especial na contemporaneidade, este é meu principal interesse e tarefa neste momento. Vamos entrar agora neste caudaloso rio. 


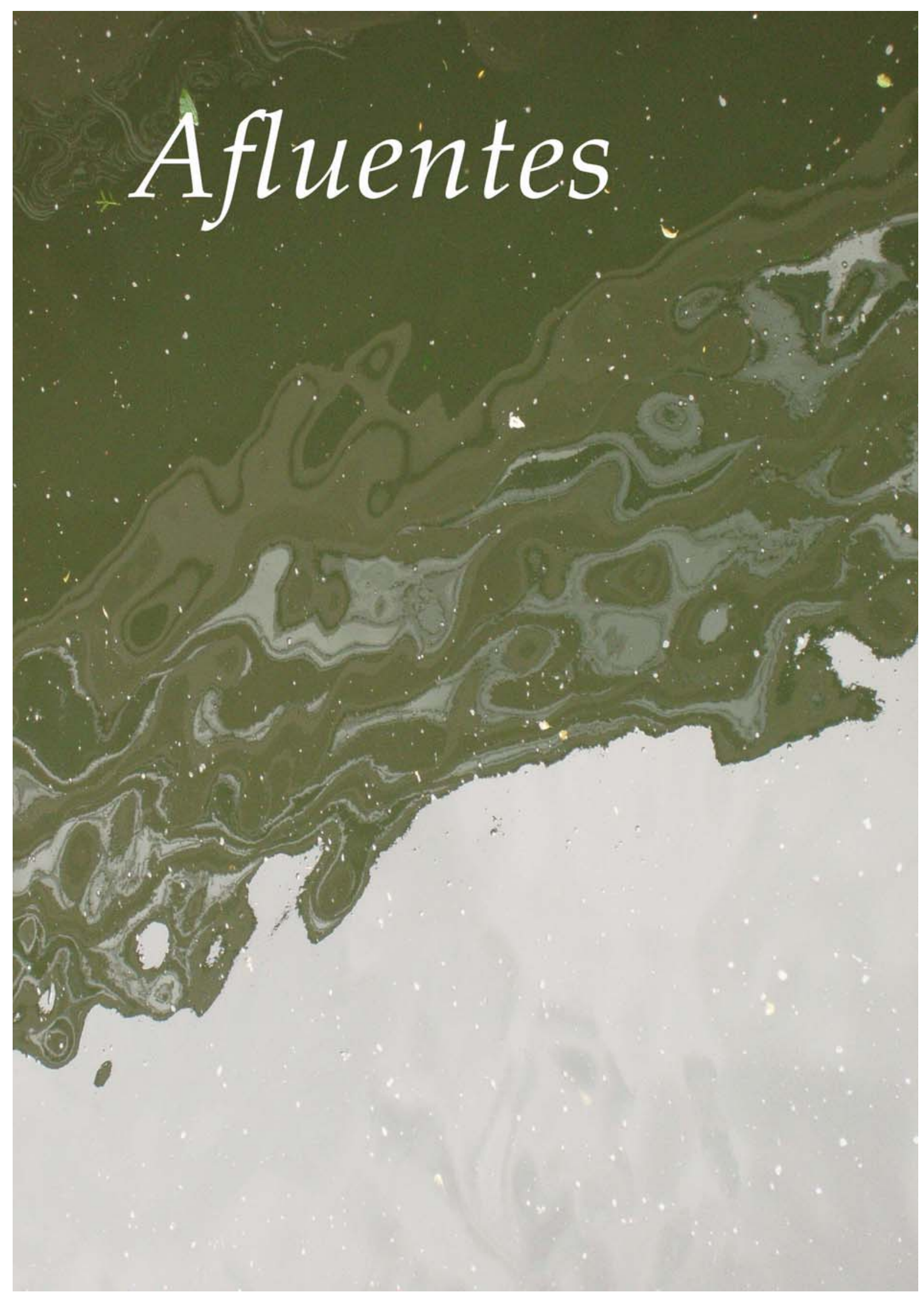




\section{A água como representação na arte}

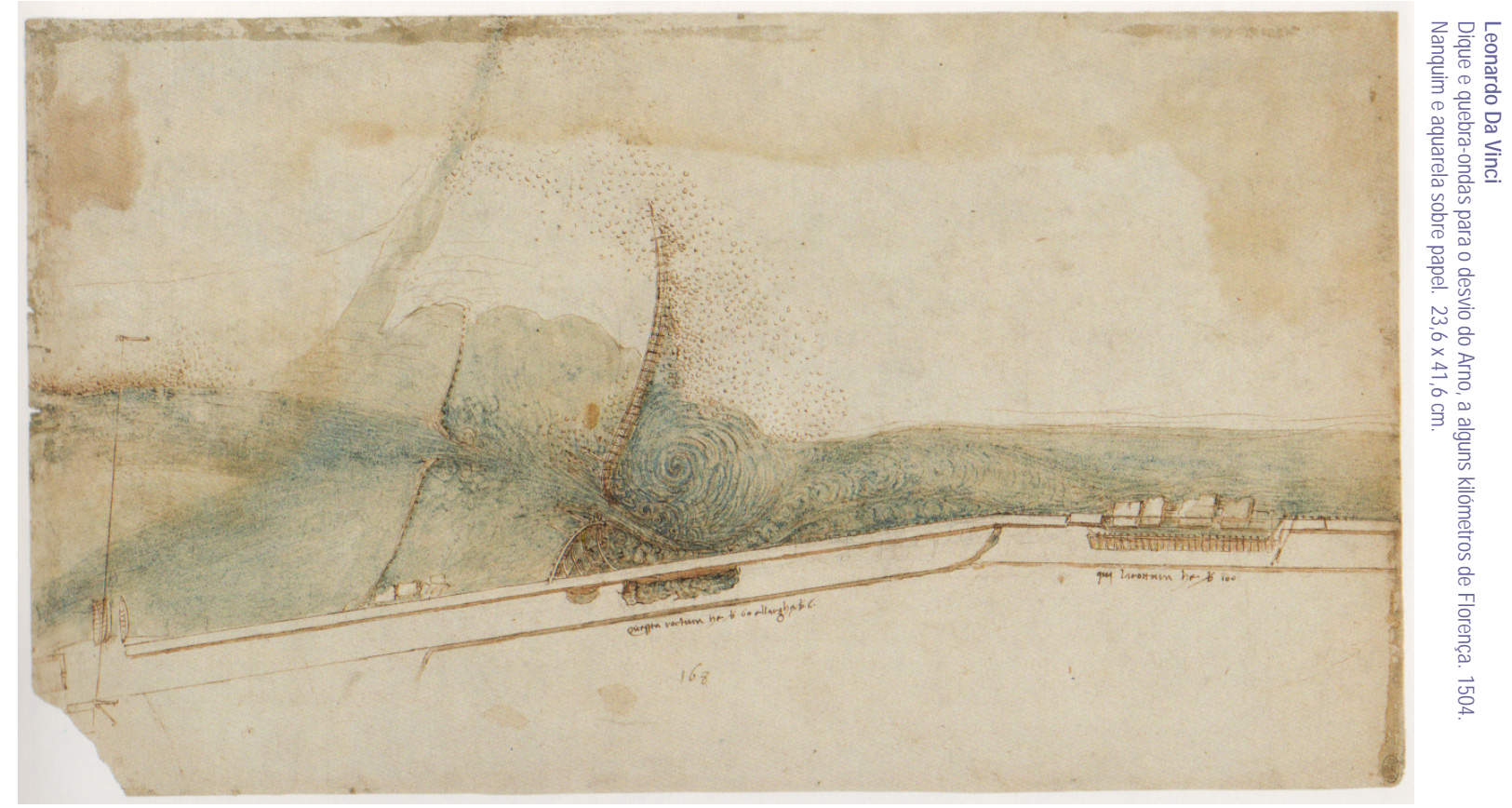

Paralelamente ao desenvolvimento dos hábitos, crenças e visões de mundo dos povos, que formam as grandes narrativas da cultura e servem como base e inspiração para a criação artística, também a arte apresenta narrativas e procedimentos em seu próprio interior, que contribuem para a formação de iconografias e imaginários sociais, que influem na constituição e no desenvolvimento dos estilos e concepções artísticas de cada época. Desta forma, as imagens da água produzidas pela arte do passado, servem muitas vezes como ponto de partida para as imagens da água no presente, quer sejam como fontes de referência, quer sejam para serem transformadas ou contestadas.

Nas obras contemporâneas, a água ou os líquidos aparecem não só como tema através de uma imagem de representação, mas como material constituinte da obra. Acredito, entretanto, que mesmo as obras que utilizam a água como material, muitas vezes baseiam-se no significado histórico das imagens da água e travam diálogos com a tradição. Assim, faz-se necessário estudar as imagens de representação da água no passado para entender a utilização da água em muitas obras do presente. 
Numa perspectiva histórica, pode-se dizer que a água surge primeiramente como tema na arte, e só depois como material integrante da obra. Embora fosse possível considerar o desenvolvimento das fontes como um exemplo da utilização da água enquanto material na arte, acredito que o emprego da água na arte contemporânea relaciona-se mais diretamente com o desenvolvimento das artes plásticas em geral, do que ao campo específico da construção de fontes, que se aproxima mais da arquitetura e da jardinagem. Por este motivo, prefiro dedicar-me neste histórico prioritariamente ao estudo das imagens da água nas artes plásticas, do que examinar com profundidade o desenvolvimento histórico das fontes.

Até praticamente o final da primeira metade do século $X X$, a água aparecia representada mais freqüentemente na pintura, não sendo tão comum na escultura. Enquanto na pintura foi possível a representação dos rios e mares e das nuances da água na paisagem nas mais diferentes concepções estilísticas, a figuração da água pela escultura assumiu geralmente características alegóricas, sendo traduzida pela representação de criaturas mitológicas ligadas à água, como Netuno ou as Sereias, ou pela ornamentação que incluia uma quantidade de conchas, peixes e outros seres marinhos, como é comum na arte barroca, por exemplo.

Tradicionalmente a pintura foi tida como mais própria do que a escultura para a representação da transparência, das qualidades atmosféricas e dos estados transitórios; isso explica a predominância da representação da água na pintura, em detrimento da escultura. Tal concepção é mencionada já por Leonardo Da Vinci, que enumera diversos efeitos que são obtidos com mais eficácia na pintura, entre eles a representação da superfície aquática: "corpos reluzentes, neblina, tempo escuro, chuvas, superfície das águas, variações da cor do ar, poeira, os rios mais ou menos densos, peixes brincando..." 17

Leonardo é também um dos primeiros artistas a dedicar escritos sobre água, principalmente no que se refere à observação objetiva da água e à aplicação prática de conhecimentos de hidrologia. Seus escritos e desenhos sobre água, que foram desenvolvidos de maneira desordenada e dispersa, encontram-se hoje reunidos no "Livro da água", que apresenta um grande panorama dos conhecimentos do artista sobre o assunto. Leonardo escreveu sobre o movimento e forma das ondas e correntes marítimas, fez inúmeros projetos para irrigação e desvios de rios, como o rio Arno, realizou estudos para o desenvolvimento de canais, bombas e moinhos d'água, criou artefatos para se caminhar sobre as águas e desenhou mapas hidrológicos de certas regiões. Ele ainda realizou desenhos analisando o formato das gotas d'água e representou as correntes formadas no dilúvio. 


\subsection{Artérias da terra, fonte de vida, água da purificação}

A água para Leonardo não é apenas matéria para suas pesquisas práticas, mas aparece também representada nos rios que serpenteiam nas paisagens distantes do plano de fundo de suas pinturas. Este tipo de paisagem montanhosa, entrecortada por rios, é bastante típico nos quadros da maioria dos pintores da época, porém adquire em Leonardo características atmosféricas especiais pelo emprego suave da luz.

Nos escritos de Leonardo encontram-se considerações a respeito das relações entre luz e água e analogias entre o corpo do homem e o corpo da terra. Nestas analogias, pode-se encontrar, por exemplo, desenhos que aproximam o movimento das correntes aquáticas às tranças de cabelos, ou relações entre os rios e as veias do corpo humano. Segundo esta concepção, comum na época, os rios eram formados não pelas águas da chuva e pela evaporação, mas seriam veias que viriam do interior da terra doando vida à superfície. Para a historiadora alemã Ute Seiderer ${ }^{18}$, tal concepção explica a maneira como os rios são representados na obra de Leonardo e de muitos outros artistas de seu período. Nestas representações, os rios aparecem como se sua origem fosse no fundo distante da paisagem e serpenteiam até chegar ao primeiro plano do quadro. Além de estar ligada ao desenvolvimento da perspectiva, esta forma de representação também assinala o caráter simbólico da presença da água.

Quando se observam os tradicionais quadros sobre o batismo de Cristo realizados no período renascentista, esta presença simbólica é ressaltada. Em um tríptico de Rogier van der Weyden, observa-se a presença central do rio, onde Cristo recebe o sacramento do Batismo. Na parte superior central do quadro, vê-se a imagem de Deus, inserido no clarão do sol, de onde são emitidas palavras em um movimento semelhante ao do rio que se encontra logo abaixo. O eixo formado pelo sol, pelas palavras e pelo rio é onde se localiza o corpo de Cristo. $\mathrm{Na}$ simbologia do quadro, este eixo cumpre a função de demonstrar a transmissão de energia existente entre a vida celeste e a vida terrena e exaltar a ligação entre o homem e Deus pelo sacramento do batismo. A água, na qual Cristo molha os pés e é batizado é símbolo para a purificação e o recebimento do sacramento.

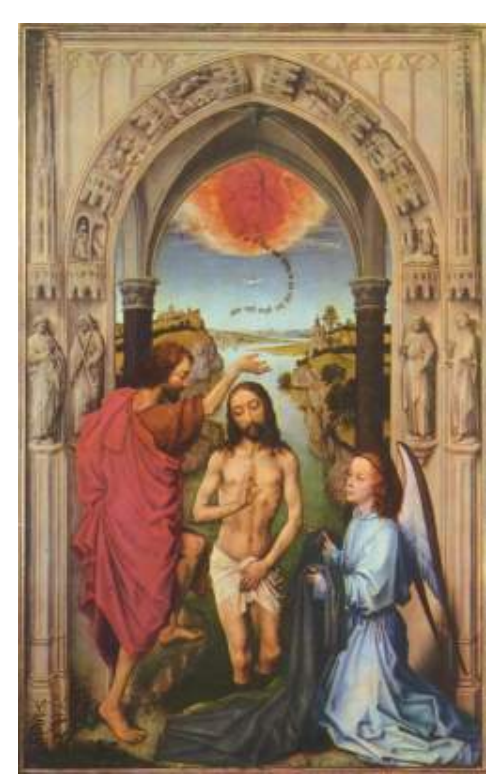


A existência de um pórtico com esculturas, que aparece no primeiro plano da pintura como uma moldura, demonstra que esta pintura não retrata uma natureza real existente, mas constitui na verdade um espaço simbólico de representação. 0 pórtico, pintado em praticamente uma única cor, contrasta com o fundo extremamente colorido. O pintor deixa claro aqui a supremacia da pintura em relação à escultura, que aparece monocromática e como ornamento da cena.

A constituição de um espaço simbólico no qual a idéia dos rios como artérias da terra é apresentada pode ser observada também na obra "A madona do Chanceler Rolin" de Jan van Eyck. Novamente o rio origina-se no ponto central mais distante do plano de fundo de quadro, serpenteando em direção ao primeiro plano. Esta pequena paisagem de fundo é porém interrompida por um pórtico que delimita o espaço da sala onde se encontram a Virgem com o Menino Jesus à

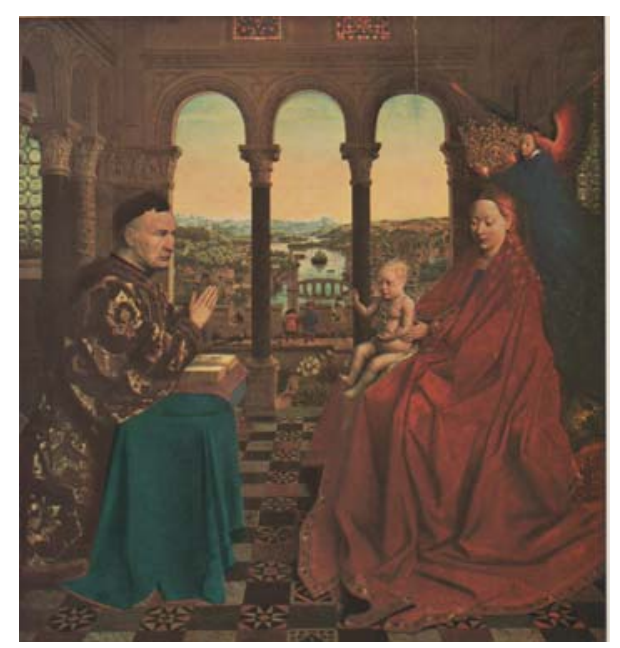
direita e o Kanzler à esquerda. O palácio no qual se desenvolve a cena teria que ter sido construído praticamente sobre o rio para que se pudesse ter uma vista da paisagem como aquela, o que para a arquitetura da época ainda seria impossível. Também aqui observa-se uma representação muito mais baseada na constituição de um espaço simbólico, do que uma busca de fidelidade à realidade.

O simbolismo da água como fonte de vida e energia espiritual não aparece apenas na representação de rios na pintura renascentista, mas também em obras em que sua presença como elemento místico sobrepôe-se a necessidade de verossimilhança com a paisagem natural. Um exemplo são os lagos e chafarizes existentes predominantemente na representação do paraíso no tríptico "O Jardim das Delícias" de Hyeronimus Bosch. Embora apareça também no painel central do tríptico, que retrata a luxúria, a água quase não aparece no painel da direita, que representa o inferno, onde o elemento preponderante é o fogo. 


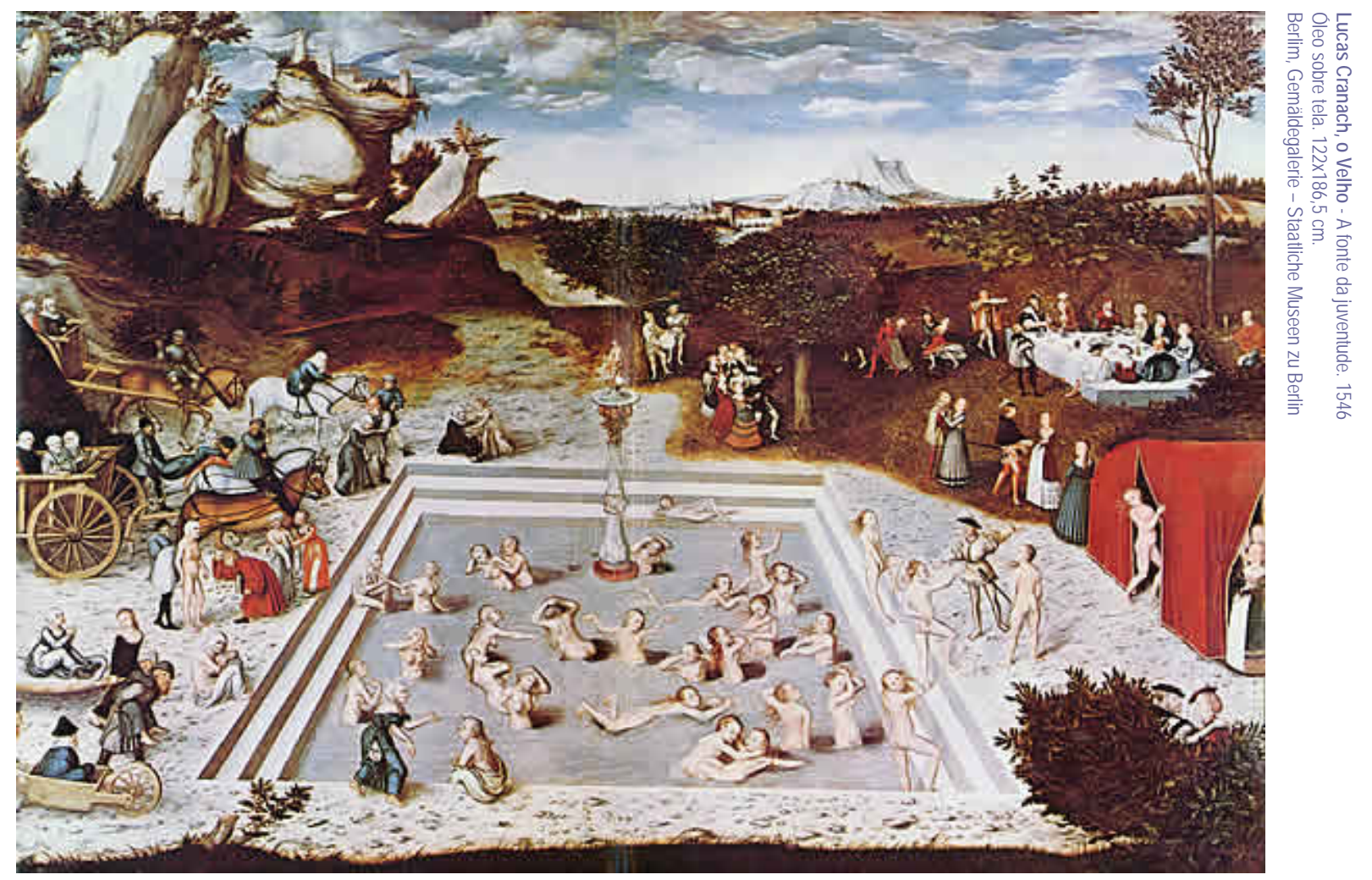

Outro exemplo interessante é "A fonte da juventude" do artista alemão Lucas Cranach, o Velho. Este quadro retrata o ambiente de uma paisagem onde se encontra um lago ou fonte para onde são trazidas velhas mulheres que surgem pelo lado esquerdo da cena e, ao adentrar o lago, dirigem-se para o lado direito e vão sendo remoçadas até sairem do lago como jovens e serem abraçadas por homens galanteadores. É interessante notar que apenas as mulheres entram na fonte em busca da juventude; aos homens a aparência e a preocupação com a idade não seriam tão importantes. Nesta alegoria, baseada mais nas crendices populares do que nas concepções religiosas, o pintor nos oferece uma visão da efemeridade da vida e a busca do homem em prolongá-la ou conter seu fluxo. A água é apresentada aqui não só como fonte de vida e renovação, mas também como elemento que incita a sensualidade e à sedução. 


\subsection{A água navegável}

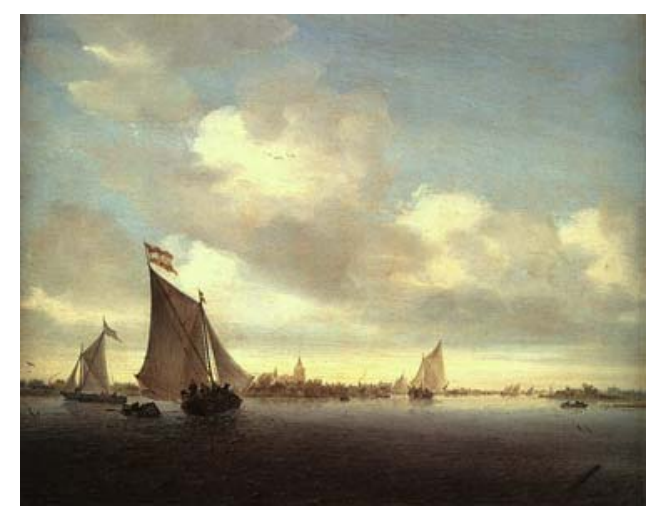

À medida em que nos aproximamos do século XVII, há um arrefecimento da representação de motivos católicos e a pintura começa a retratar o ambiente cotidiano, em especial nos países baixos. Se no Renascimento a paisagem, e por consequência os rios, apareciam mais como pano de fundo, a pintura holandesa seiscentista Ihes confere um lugar de honra. As terras baixas, banhadas pelo mar e por amplos rios navegáveis, são retratadas com objetividade e frescor pelos pintores holandeses. $\mathrm{O}$ espaço pictórico, que anteriormente organizava-se por eixos verticais hierárquicos, torna-se mais horizontal, de modo a ressaltar a presença do céu e o espraiamento das águas. A linha do horizonte é rebaixada e os rios são retratados não mais por inteiro e serpenteantes, mas seccionados pelas bordas do quadro, sugerindo o seu prolongamento pelas laterais. Pode-se dizer que a profundidade perspectivesca acentuada do renascimento é substituída pela amplidão do espaço. A água é aqui retratada de forma mais objetiva e menos religiosa. A paisagem banhada de água serve de palco para a representação das atividades diárias da vida mundana. Esta água serve para a pesca, para o transporte de mercadorias, para a diversão e o desenvolvimento das atividades sociais. O que se celebra aqui é a proximidade do homem comum com a natureza, que the serve como meio para subsistência, fonte de prazer e cenário para a vida. Artistas como Salomon van Ruysdael, Willem van de Velde e Jan van Goyen desenvolvem o gênero da pintura de paisagens. Em seus quadros pode-se ver tanto cenas em que a cidade e a natureza aparecem banhadas pelos rios, como as típicas marinhas, com seus barcos a vela.

A tradição paisagística holandesa, que nos apresenta uma visão relativamente objetiva da natureza, é a mesma que informa a criação das primeiras imagens em que a água brasileira é representada. $O$ holandês Frans Janzs Post é o primeiro pintor a representar esta "nova" natureza. Vindo em 1636 à corte de Maurício de Nassau no Recife, Frans Post documenta a paisagem brasileira segundo um padrão de representação europeu. "Por esse motivo suas obras, apesar de brasileiras, não deixam de ser holandesas e suas paisagens, instigantemente estranhas para um europeu de seu tempo, se comparam e aproximam formalmente daquelas de Ruysdael, de Koninck ou de Van Goyen. (...) Era preciso pintar as margens do rio São Francisco, ou a distante cidade da Paraíba, com a mesma naturalidade com que Vermeer pintava a conhecida cidade de Delft vista de suas águas"19. No caso 
brasileiro, porém, ao invés da movimentação intensa das embarcações, o que se destaca são os exóticos animais e a vegetação tropical.

A impossibilidade de se retratar imagens de Deus e de santos na fé protestante holandesa, transfere a espiritualidade para o sentimento de comunhão com a natureza e a contemplação da amplidão e do vazio. Embora não mais de maneira alegórica e personificada, a presença de Deus é poeticamente evocada pela amplidão do céu, nas paisagens, ou pela vacuidade diante do sentimento da morte, nas naturezas mortas. Neste último gênero, a representação da água e de outros líquidos como o vinho ou o azeite também merece destaque. Os artistas se esmeram na representação da transparência destes líquidos exibidos em taças e jarras cristalinas e brilhantes. A representação virtuosa da transparência dos líquidos confere uma atmosfera ainda mais misteriosa e solene às cenas, acentuando a evidência do vazio e aumentando a sensação de vanitas.

No século XVIII, o interesse em retratar as cenas cotidianas ao redor das paisagens aquáticas é retomado em especial pelos pintores venezianos, em especial por Canaletto. Embora nas paisagens holandesas já houvesse a representação das atividades cotidianas, seu ambiente ainda apresenta-se mais idílico e rural, enquanto que na obra de Canaletto o que se destaca é a arquitetura e a vida agitada da "metrópole" do mediterrâneo. O ambiente aquático serve de palco para a agitação e a alegria das gôndolas em movimento. Na obra de Canaletto, a água evidencia a luz mediterrânea e os reflexos da arquitetura. A superfície da água é mais "dura" e espelhada, e suas ondas são representadas de maneira quase esquemática, e o desenho linear rígido sobrepõe-se à atmosfera pictórica.

\subsection{A fluidez dos sentimentos}


A partir da segunda metade do século XVIII, com o desenvolvimento da cultura do Iluminismo, com a constituição de uma sociedade cada vez mais urbana e com o fortalecimento das correntes ideológicas, o homem passa a pensar-se como cidadão que estabelece uma relação não só com a natureza, mas também com a sociedade que o circunda. Assim, a natureza objetiva deixa de ser o assunto principal de sua criação, para tornar-se o entorno de sua experiência social, estabelecendo assim relações mais complexas com o indivíduo.

A natureza passa a ser pintada como espaço para a expressão dos sentimentos dos artistas e seus questionamentos sobre sua experiência de estar no mundo, e não apenas como um cenário objetivo para o desenvolvimento da vida ou como um depositário de simbolismos ditados pela religião.

Os ideais românticos seguidos por estes artistas, em particular aqueles ligados às poéticas do Sublime, pregam uma vivência mais fluida, baseada nas emoções e sensações e menos calcada na realidade concreta e de contornos fixos e imutáveis. As brumas, tempestades, névoas e os grandes acidentes da paisagem, como cataratas e geleiras passam a frequentar o vocabulário imagético dos pintores da época. Os líquidos, por apresentarem-se em diferentes estados transitórios, serem mais aptos a transformações e mostrarem-se de maneira mais informe, passam a ter uma importância metafórica maior no trabalho de alguns artistas, servindo-se à expressão de sentimentos muitas vezes difíceis de serem formalizados de maneira concreta.

O surgimento do conceito de Sublime nos escritos de estética da época influencia os artistas na busca de uma nova ordem de representação da natureza. Mencionado pela primeira vez por Edmund Burke em 1757, o conceito de Sublime é posteriormente desenvolvido e aprofundado por Kant.

O Sublime reúne uma série de características opostas ao Belo.

Ao invés de inspirar graça ou alegria, o Sublime causa comoção, seriedade e respeito. Uma flor pode ser bela, porém a visão do mar, de uma tempestade ou de um despenhadeiro são sublimes. Tais exemplos de paisagem líquida, como o mar e a tempestade, são mencionados pelo próprio Kant como acontecimentos geográficos sublimes.

As diferenças entre Belo e Sublime säo claramente visualizadas também nas descrições de Giulio Carlo Argan sobre as poéticas do sublime e do pitoresco: "la poética de lo 'sublime' y la del Sturm und Drang, aunque poco posteriores a la poética de lo 'pintoresco', no son opuestas, sino que simplemente reflejan una distinta actitud del individuo hacia la realidad: para lo 'pintoresco', la naturaleza es un 
ambiente acogedor y propicio que desarolla en el individuo los sentimientos sociales; para lo 'sublime', es un ambiente duro y hostil que desarolla en la persona el sentido de su propia individualidad, de su propia soledad, de la tragedia fundamental del existir."

Enquanto o Belo é relativo e pode ser pequeno, o Sublime tem que ser necessariamente grande e é um valor absoluto, que não se compara. A noção de Sublime relaciona-se à idéia de infinito, de um valor supremo, espiritual, embora não ligado necessariamente a esta ou aquela religião. O prazer que o Sublime nos proporciona é descrito por Kant como um prazer negativo. Diante de uma tempestade ou de um despenhadeiro podemos ser tomados pelo pavor ou por emoções violentas que remetem muito mais à idéia de Sublime do que à de Belo. Ao invés de depender da noção de forma, como acontece com o Belo, o Sublime, por conter esta dimensão infinita e desmesurada, não se observa a partir de uma forma limitada, mas geralmente a partir de um objeto sem forma. A noção de contenção, relacionada ao Belo, é descartada pelo Sublime, que a substitui pela expansão incontida. A água, por ser um material informe e fluido, possuir força incontrolável e ao mesmo tempo remeter a estados de contemplação reúne diversas características que podem associar-se à representação do Sublime.

Para Kant, o Sublime, assim como o Belo, depende de um juízo reflexionante, porém se as coisas belas podem nos levar à reflexão por conceitos identificáveis, as coisas sublimes nos remetem diretamente à Idéias da Razão que não são representáveis através de conceitos. Assim, o Sublime, alcançaria um patamar superior ao Belo podendo suscitar idéias absolutas e indizíveis.

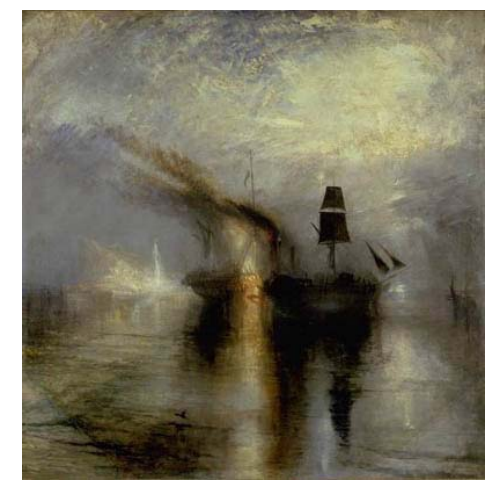

A influência das concepções do Sublime sobre a arte dos Românticos, especialmente foi fundamental. Artistas alemães como Caspar David Friedrich e Joseph Anton Koch ou o inglês William Turner buscaram na força da natureza e em suas transformações a expressão de sentimentos e estados de ânimo.

No trabalho de William Turner pode-se ver paisagens marítimas quase abstratas, tomadas por uma atmosfera convulsiva que dissolve o contorno das coisas apontando para a relação entre elas, através de explosões de luz e cor que se mesclam indefinidadente. A presença dos líquidos não está apenas no motivo retratado, mas na própria maneira de retratá-lo, já que a tinta, às vezes em camadas quase liqüefeitas, confere transparência e fluidez às imagens, estabelecendo um movimento de manchas que se assemelham ao movimento das luzes na água e aos respingos e vapores causados pelas tormentas. O espaço, nas 
telas de Turner, não é esquadrinhado pela perspectiva tradicional, mas ao contrário, quase se materializa em uma atmosfera densa e ao mesmo tempo fluida. É um espaço que, ao invés de afastar as coisas umas das outras e definí-las, submergeas todas, quase a desfazê-las em um turbilhão de luz e vazios. As inconstâncias das águas e da alma são aqui igualadas em uma pintura que não se pode conter, em uma imagem que escorre e que flui como a sensação de uma onda que se esvai.

A importância dos líquidos na obra de Turner observa-se não só em termos simbólicos, mas também em termos formais e no processo de fatura da pintura. À medida em que os contornos dos objetos retratados tendem a se dissolver pelas pinceladas, destaca-se o caráter líquido-pastoso da tinta que constitui as obras, fazendo com que o trabalho do artista fique cada vez mais evidenciado, ao invés de disfarçado como na pintura da tradição clássica. As finas camadas transparentes de tinta também acentuam o caráter líquido de sua pintura. Turner foi ainda reconhecido como grande aquarelista. Em suas aquarelas pode-se perceber uma atmosfera ainda mais diáfana, fluida, solta e informe, tendendo à abstração.

Já na obra de Caspar David Friedrich, a pincelada ocorre de maneira mais contida, porém os líquidos se apresentam ainda como importante tema para a expressão de sensações sublimes. $O$ retrato de paisagens geladas e nebulosas acentua o vazio e a solidão do homem perante a natureza misteriosa. Ao invés das tempestades turbulentas de Turner, Friedrich prefere o silêncio das brumas e do gelo. É interessante notar, que nas paisagens de Friedrich os líquidos não aparecem com a mesma fluidez dos trabalhos de Turner, mas indicam sua presença em estados transitórios, solidificados nos icebergs e geleiras ou evaporados em suspensão nas neblinas e maresias embaçadas. 


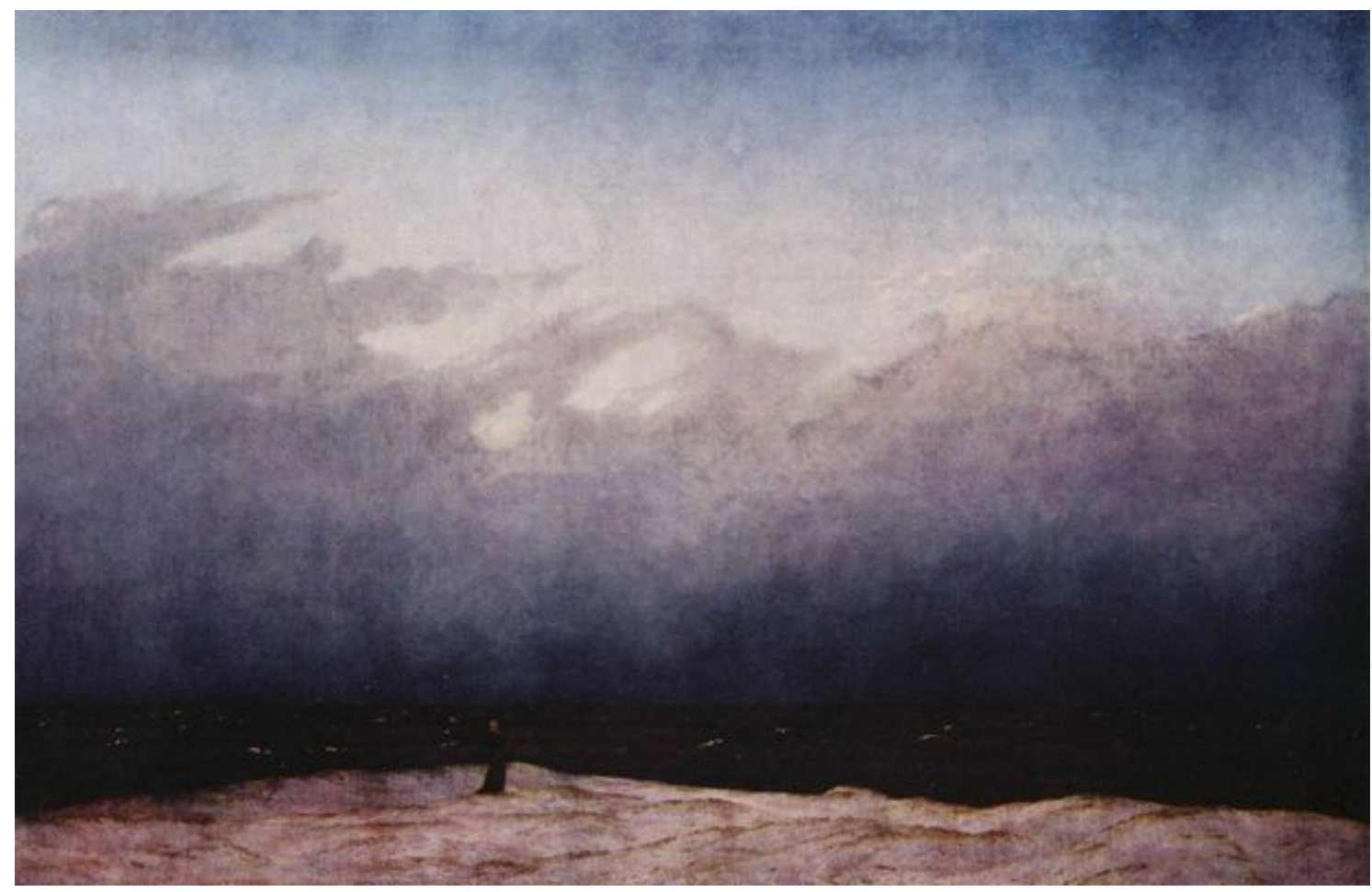

Enquanto em Turner a água se apresenta em toda sua força e violência como elemento natural, no trabalho de Friedrich ela surge em estados transitórios de suspensão, como os vapores e o gelo. Enquanto Turner nos apresenta a fraqueza do homem perante a força movimentada da natureza, Friedrich medita sobre a impossibilidade de conter o tempo e a solidão humana. Em sua tela "Monge no mar" um homem parece contemplar o vazio e a imensidão. Já em " O destroço do Esperança" é assinalada a trajédia humana dentro do naufrágio nas geleiras.

O interesse dos artistas desta época pelos elementos líquidos observa-se no próprio nome do movimento artístico-literário alemão Sturm und Drang, que surge na passagem do século XVIII para o XIX, mas já reúne as características do que viria a ser o romantismo. Sturm em alemão significa tempestade, temporal com vento forte, tormenta, enquanto que Drang significa impulso, ânsia, desejo, ímpeto. Para os artistas ligados ao movimento Sturm und Drang "el arte es la expresión de lo irracional $y$, por tanto, de los impulsos y de los sentimientos con los que la espiritualidad humana reacciona frente a la realidad natural, afrontándola o evadiéndose en el sueño." 20 A imagem da tempestade serve como metáfora para a expressão destas sensações.

O século XIX, entretanto, não é apenas uma época sentimental de sensações desmedidas, mas é também um momento em que a ciência volta-se para a natureza, procurando estudá-la em seus mínimos detalhes. A ciência apresenta agora uma natureza em constante transformação e não apenas como um modelo estático. O estudo científico das nuvens ${ }^{21}$, desenvolvido pelo pioneiro da meteorologia Luke Howard por exemplo, que classificava as nuvens em Cirrus, 
Stratus e Cumulus, torna-se popular não só entre os cientistas, mas serve muitas vezes como exercício e modelo para as representações do céu nas academias de arte do século XIX. Conta-se que Goethe teria discutido com Caspar David Friedrich, pois o primeiro pensava que o segundo deveria basear-se nestes estudos científicos para representar as nuvens em seus quadros, enquanto que Friedrich preferia pintálas livremente, de acordo com as suas emoções. As nuvens, acúmulos de gases e vapores informes como a água, deveriam estar para Friedrich a serviço da expressão.

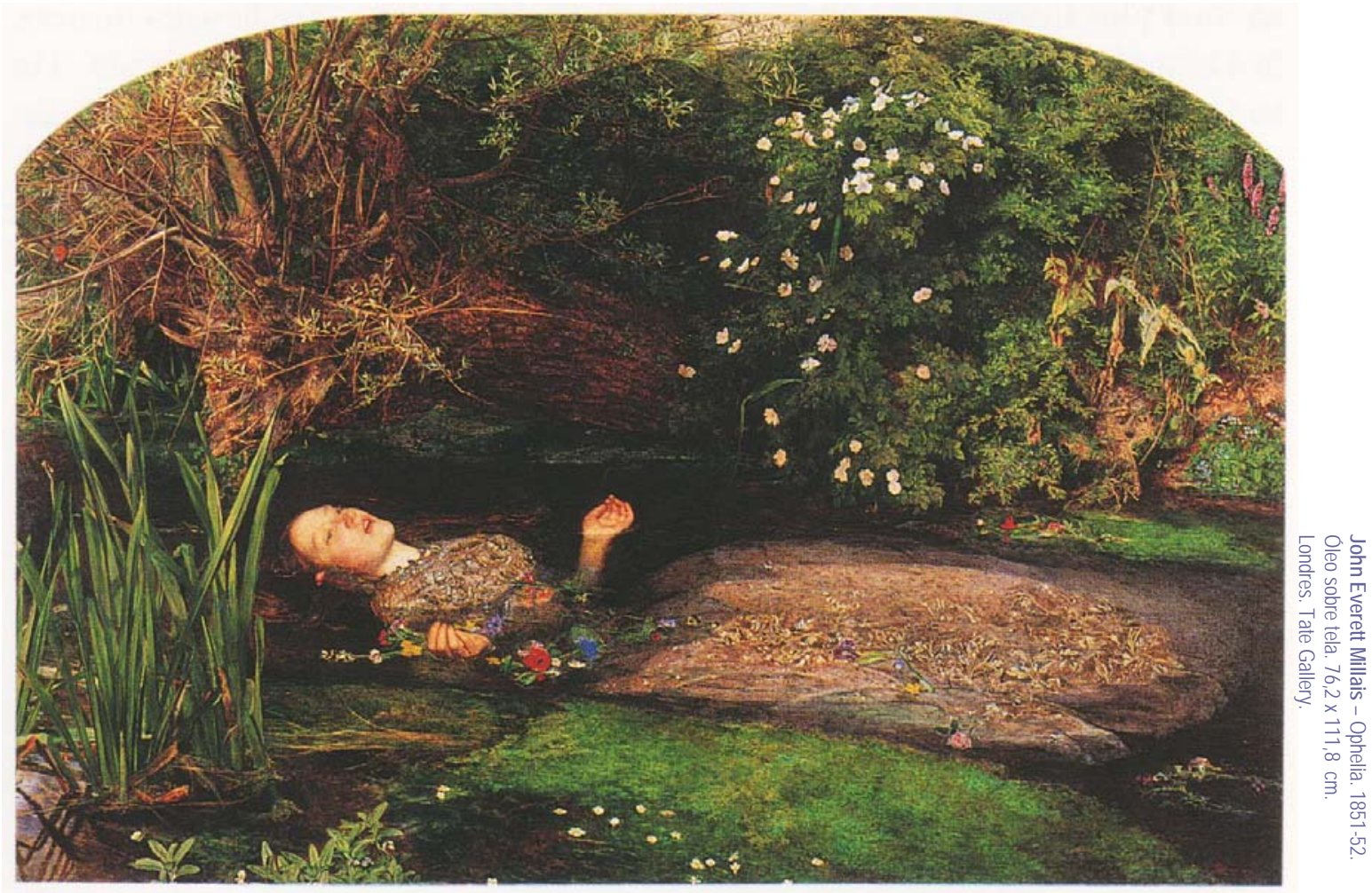

Mas a observação precisa e minuciosa da natureza agregada a um certo sentimento romântico parece ter encontrado seu equilíbrio entre os pintores pré-rafaelitas ingleses. Em sua técnica quase fotográfica, o pré-rafaelita John Everett Millais nos apresenta em sua representação de Ofélia de Shakespeare uma cena banhada de sonho e espiritualidade. Sua Ofélia bóia belíssima em uma espécie de transe sobre as águas do rio que irá tragá-la. Sua fragilidade e efemeridade dominam a poética cena. Obviamente, trata-se da representação de uma morte bela e idealizada. Sua flutuação, ressaltada pela leveza do vestido e de sua posição corporal confere uma conotação espiritual à cena, cuja personagem encontra-se num estágio intermediário entre a vida e a morte. A precisão de detalhes com que Millais pinta a cena chega a impressionar até botânicos. Ao mesmo tempo que a arte dos pré-rafaelistas comunga com o espírito de observação científica da época, ela busca uma volta as tradições da pintura e um certo preciosismo saudosista.

\subsection{A inconstância dos reflexos e o prazer cotidiano.}


Os avanços científicos do final do século XIX permitem que o homem tenha uma nova visão da constituição ótica da luz. Chega-se assim ao impressionismo, onde a busca da compreensão física da luz decompõe opticamente a cor dividindo-a em pinceladas aparentes. O caminho aberto pelos românticos, em especial por Turner, no sentido da liberação da pincelada em benefício da expressão, é aprofundado pelos impressionistas, que fundam uma nova forma de ver a cor. O interesse dos impressionistas pela luz e pelos seus estados transitórios, também encontra nas paisagens com elementos aquáticos um bom motivo para o desenvolvimento de seus efeitos ópticos. A inconstância trazida pelo movimento aquático e seus reflexos de cores decompostas pela propriedade prismática da água ocupam boa parte dos interesses dos impressionistas. Ao invés de buscar paisagens sublimes e grandiosas, os impressionistas preferem entretanto as águas cristalinas da diversão e dos prazeres cotidianos. Lagos em parques, pescarias, regatas e refeições a beiramar são temas comuns em suas pinturas.

A água, mesmo quando apenas elemento auxiliar da composição, emite suas luzes fluídas que se refletem nos rostos das pessoas ou na superfície das coisas. Ao invés da dimensão trágica e simbólica assumida pela água nas pinturas românticas, o que se destaca entre os impressionistas é a investigação dos processos físicos de reflexão e refração da luz proporcionados pelo meio aquoso, que conferem uma certa transitoriedade e instabilidade às cenas impressionistas.

A própria pintura que dá origem ao nome do movimento impressionista, o quadro Impression, soleil levant pintado em 1873 por Monet, representa uma paisagem marítima onde navegam barcos com um porto ao fundo. A representação da água é um tema extremamente presente em Monet, e apresenta-se em obras bastante conhecidas como La Grenouillère (1869), La Manneporte (1883), além das séries sobre o Tâmisa e sobre os Jardins de Giverny e suas ninféias (1889 a 1925).

O interesse pela representação da água chega até os fauvistas, em especial nas marinhas de Raoul Dufy. Ao invés da qualidade cintilante produzida pelas pequenas pinceladas dos impressionistas, o que se vê em Raoul Dufy são manchas maiores de cor, em que o azul e suas matizes atingem uma profunda intensidade. Grande parte de sua obra retrata a Riviera Francesa e o Mediterrâneo.

A pintura européia sempre foi fonte de informação para os artistas brasileiros, especialmente na sua fase pré-moderna. A produção brasileira do final do século XIX e início do século XX não chega a constituir escolas próprias e grande parte dos artistas são de origem européia. A representação da água e da paisagem na pintura 
brasileira desta época baseia-se na formação acadêmica européia, recebendo maior ou menor influencia das vanguardas.

Em relação às poéticas líquidas, destacam-se na arte brasileira do final do século $\mathrm{XIX}$ as marinhas de Castagneto. Embora com traços acadêmicos, a obra de Castagneto apresenta uma certa liberdade formal, construída a partir de uma pincelada mais solta que é muitas vezes associada ao romantismo e ao impressionismo. Nascido na Itália, em 1851, Castagneto chega ao Rio de Janeiro com 23 anos, onde se emprega como marinheiro. Sua observação da matéria mutante da água, aliada a uma sensível visão afetiva da natureza, revela uma reflexão sobre a instabilidade da experiência humana. Sua fatura é espatulada e ritmada, buscando uma equivalência entre as matérias compactas e fluidas.

Outros artistas brasileiros que se destacam nas pinturas de marinhas são Benedito Calixto e Pancetti. Benedito Calixto busca um retrato mais acadêmico e documental do litoral paulista. Sua pintura, baseada em cartões postais antigos, revela uma natureza de certa forma idealizada e agradável. Pancetti, já contemporâneo do modernismo, chega a executar pinturas onde a fidelidade ao motivo retratado é minimizada, chegando a uma síntese quase abstrata da luminosidade marítima. Suas grandes áreas de massa pictórica aproximam-se do interesse fauvista, destacando as cores verde-azuladas e terrosas.

\subsection{Escorrer, flutuar, respingar}

É importante notar, que desde o início do romantismo, passando pelo impressionismo e desaguando nas correntes modernas, ocorrem transformações profundas nas maneiras de se pensar e ver a arte. A matéria pictórica passa a ganhar maior autonomia, deixando paulatinamente em evidência o trabalho manual do artista e a planaridade da pintura. Com esta valorização crescente da matéria pictórica, os artistas começam a revelar ao espectador a constituição líquida-pastosa da tinta. Ao mesmo tempo, os temas da pintura vão aos poucos se libertando de sua necessidade de narração, baseada em metáforas verbais ou formais e surgem possibilidades de expressão mais ancoradas nas imagens e sensações materiais. "Essas imagens da matéria, nós as sonhamos substancialmente, intimamente, afastando as formas, as formas perecíveis, as vãs imagens, o devir das superfícies." A imaginação material guarda em si "um lastro, uma densidade, uma lentidão, uma germinação"22, nos diz Bachelard.

Os líquidos, enquanto matéria, passam a ser vistos pela arte como passíveis de abrigar significados que se deduzem de seus próprios processos e características 
fenomenológicas. O interesse dos artistas volta-se para a produção de obras que sejam percebidas sensorialmente, e não mais ligadas necessariamente a metáforas religiosas, ideológicas ou literárias. As sensações corporais que os líquidos proporcionam e suas características físicas como a fluidez, a flutuação ou a transparência ou a instabilidade começam a ser exploradas independentemente pelos artistas. Obviamente isto ocorre não só com relação a representação da água e dos líquidos, mas também com os processos e significações ligados aos outros materiais.

A vida essencialmente urbana que se instala definitivamente a partir do início do século $X X$, muda a relação do homem com a natureza e suas matérias. A água canalizada na cidade, não é mais a mesma que se vê nos rios renascentistas, nos mares holandeses e venezianos e nas cachoeiras e geleiras românticas. A água vista pela arte começa a ganhar uma autonomia baseada na significação de seus processos e sensações, e não é mais tão importante se ela provém dos rios ou dos mares.

A fluidez, a flutuação, o escorrimento, a forma informe e outras características e processos fenomenológicos da água e de outros líquidos passam a se tornar mais importantes para os artistas do que o puro simbolismo ligado à religião ou a representação de uma natureza ideal. Ora estes processos fenomenólogicos são representados como metáforas para sensações metafísicas e psicológicas, como na pintura dos surrealistas, ora eles são incorporados na própria fatura das obras, não mais como representação, mas como ação do artista e constituição material da obra.

Embora a presença dos líquidos ocorra de forma irregular na produção surrealista, pode-se notá-la tanto nas formas amolecidas e sensuais de Dalí como nas paisagens metafísicas pintadas por Magritte. O lânguido derretimento das formas de Dalí faz-me lembrar da densidade, da lentidão e da germinação da matéria citada por Bachelard. Não interessa tanto se é um relógio, um elefante ou um olho que escorre; o que interessa o processo de escorrer. É da fluidez informe das coisas e da inconstância da mente que nos fala Dalí. Mesmo que em algumas de suas obras o líquido não esteja representado, pode-se perceber o "liquefazer-se" dos corpos e da consciência.

Se no trabalho de Dalí os líquidos aparecem como fluídos corporais que remetem a questões da sexualidade e da passagem do tempo, na obra de Magritte, a presença da imagem onírica do mar sobre o qual flutuam pedras, gaiolas e pessoas é recorrente. Magritte coloca o tempo e a razão das coisas em suspensão. A flutuação, propriedade possível dentro do ambiente aquático, toma de assalto muitos 
dos objetos retratados por Magritte, que levitam acima do mar, extraindo deste paradoxo um espaço de silêncio e meditação metafísicos.

Enquanto no trabalho dos surrealistas os processos líquidos são representados como metáforas do inconsciente, na pintura de alguns expressionistas abstratos americanos eles aparecem na própria fatura prática do trabalho. Para estes artistas, o que se destaca é a materialidade da tinta e não sua conotação simbólica. Pollock espirra e respinga a tinta líquida sobre a tela. Na obra de Morris Louis, a tinta aguada e transparente escorre pela ação da gravidade sobre a tela, funcionando mais como um tingimento do que como uma pintura tradicional. Helen Frankenthaler também tinge telas sem preparo com tinta bastante diluída, produzindo quadros que se assemelhem a aquarelas. Mesmo que o meio de diluição da tinta não seja sempre obrigatoriamente a água, é possível perceber a utilização dos processos líquidos no trabalho destes pintores americanos. Vale lembrar entretanto, que o líquido não é aqui representado, mas sim um material que deixa rastros de sua presença na fabricação das obras.

\subsection{Artificialidade, camadas históricas e dispersão}

O crescente desaparecimento dos estilos e agrupamentos artísticos e a valorização das poéticas individuais que se impõem a partir da segunda metade do século $X X$ torna impossível a reunião dos artistas que tratam da água sob uma única categoria. Embora o modernismo traga um interesse maior pelos processos fenomenológicos dos materiais em detrimento da representação, o que irá desembocar no surgimento das intalações e dos objetos de arte, a arte contemporânea não elimina completamente a narrativa e a representação - apenas revê os seus pressupostos.

A coleção de imagens da água acumuladas ao longo da história da arte, não perde totalmente sua validade na arte contemporânea, e passa atuar como um lastro de memória, como um núcleo poético ou como citação. Este novo interesse pela imagem pode ser observado já entre os artistas pop e chega até a atualidade nas mais variadas manifestações.

Entre os artistas pop ingleses é possível reconhecer em David Rockney um especial interesse em representar a água. Sua série de quadros sobre piscinas, realizada na Califórnia, entre os quais se destaca a obra "A Bigger Splash", consegue retratar com artificialidade intencional os reflexos, as transparências, o frescor, a sensualidade e a alegria que a água proporciona. Rockney também realizou uma 
série de obras que representam homens parcialmente ou totalmente nus que tomam banho descompromissadamente, sugerindo uma atitude voyeurista e homoerótica para o observador do quadro. É interessante notar que a água aqui retratada não aparece mais como elemento ligado à natureza, mas canalizada, e representada em piscinas e chuveiros.

$\mathrm{Na}$ atualidade, este interesse recorrente por piscinas aparece, por exemplo, também no trabalho da artista chinesa Chunqing Huan. Em suas telas vêem-se corpos de adultos e crianças que se divertem nas águas das piscinas, em uma mistura de sensualidade e inocência. Ao invés de buscar a artificialidade plana de David Rockney, sua pintura dialoga com o expressionismo alemão, através de uma figuração obtida a partir de uma matéria pictórica densa e movimentada.

$\mathrm{Na}$ produção contemporânea, a representação da água nas paisagens naturais coexiste com as imagens da água no contexto urbano. Porém o pintor contemporâneo não se prende mais necessariamente à verossimilhança e às vezes utiliza as imagens da paisagem como citação ou pastiche.

O artista alemão Gerhard Richter, por exemplo, realiza uma série de pinturas que se referem às paisagens grandiosas do romantismo alemão, porém captam a movimentação das ondas do mar de maneira quase fotográfica ou como colagens de imagens dejà vu. A força do romantismo alemão verifica-se também na obra de artistas germânicos mais recentes, como no trabalho de Sonya Weber. A movimentação da água em seus quadros é obtida porém através de um minucioso trabalho de tecelagem, que prescinde da utilização da tinta.

Na pintura contemporânea brasileira nota-se uma preponderância da abstração, e apenas na produção mais recente há um aumento do interesse pela figuração. A imagem figurativa da água surge apenas esporadicamente na produção brasileira atual, embora seja possível localizar exemplos da utilização de líquidos nos processos de fabricação da pintura. Alguns dos artistas brasileiros recentes retomam certos processos pictóricos do expressionismo abstrato americano, buscando desenvolver a partir desta tradição suas próprias poéticas pessoais. As pinturas da década de 80 de Niúra Belavinha eram realizadas com tinta e lavadas com esguichadas d'água de modo a criar efeitos de escorrimento e dispersão. Também o pintor Manoel Veiga vem realizando nos últimos anos diversas pinturas em que a tinta é diluída em uma matéria líquida que é assoprada sobre a tela, de modo a percorrer caminhos sinuosos e translúcidos. Tanto na obra de Veiga como na de Belavinha, embora não haja líquidos na apresentação final do trabalho, sua aparência visual evidencia e afirma a utilização da matéria líquida no processo de confecção do trabalho. A pintura de Courtney Smith, exposta em 1998 na XXIV Bienal de São Paulo também apresenta um processo semelhante. O líquido utilizado 
pela artista é um suco de rosas, com o qual a artistas tinge a tela, criando manchas em tom avermelhado escurecido. O suco de rosas aqui, não é um pigmento neutro, mas matéria simbólica constituinte da delicada poética feminina da artista ${ }^{23}$.

A representação da água como imagem na pintura brasileira aparece no trabalho de artistas como Ana Michaelis ou Luis Ernesto. Ana Michaelis pinta paisagens esbranquiçadas e enevoadas que lembram o romantismo alemão, porém aproximam-se da pintura abstrata e do minimalismo. Luis Ernesto retrata copos d'água, torneiras e baldes de maneira quase fotográfica e os situa em grandes espaços brancos vazios, em proximidade de palavras, propondo um jogo entre signo verbal e visual. Suas telas são feitas com resina, o que aumenta a transparência dos elementos retratados e remete à liquidez da água.

Seria possível citar inúmeros outros exemplos da produção artística contemporânea brasileira e internacional, em que a água e os líquidos aparecem como representação. Meu interesse maior neste trabalho porém, é realizar uma reflexão sobre a utilização da água como material presente na arte contemporânea - dedicome a esta tarefa nos capítulos que se seguem. A contemporaneidade, porém, revela-se como um complexo inacabado e composto pela sobreposição não-linear das imagens e percepções históricas, que se somam à experiência e às visões de mundo do homem atual. A compreensão das poéticas líquidas, portanto, não pode ser vista puramente como uma sucessão cronológica de fatos e imagens, porém como um processo dinâmico, em que representação e presença se interceptam e se auto-influenciam. 


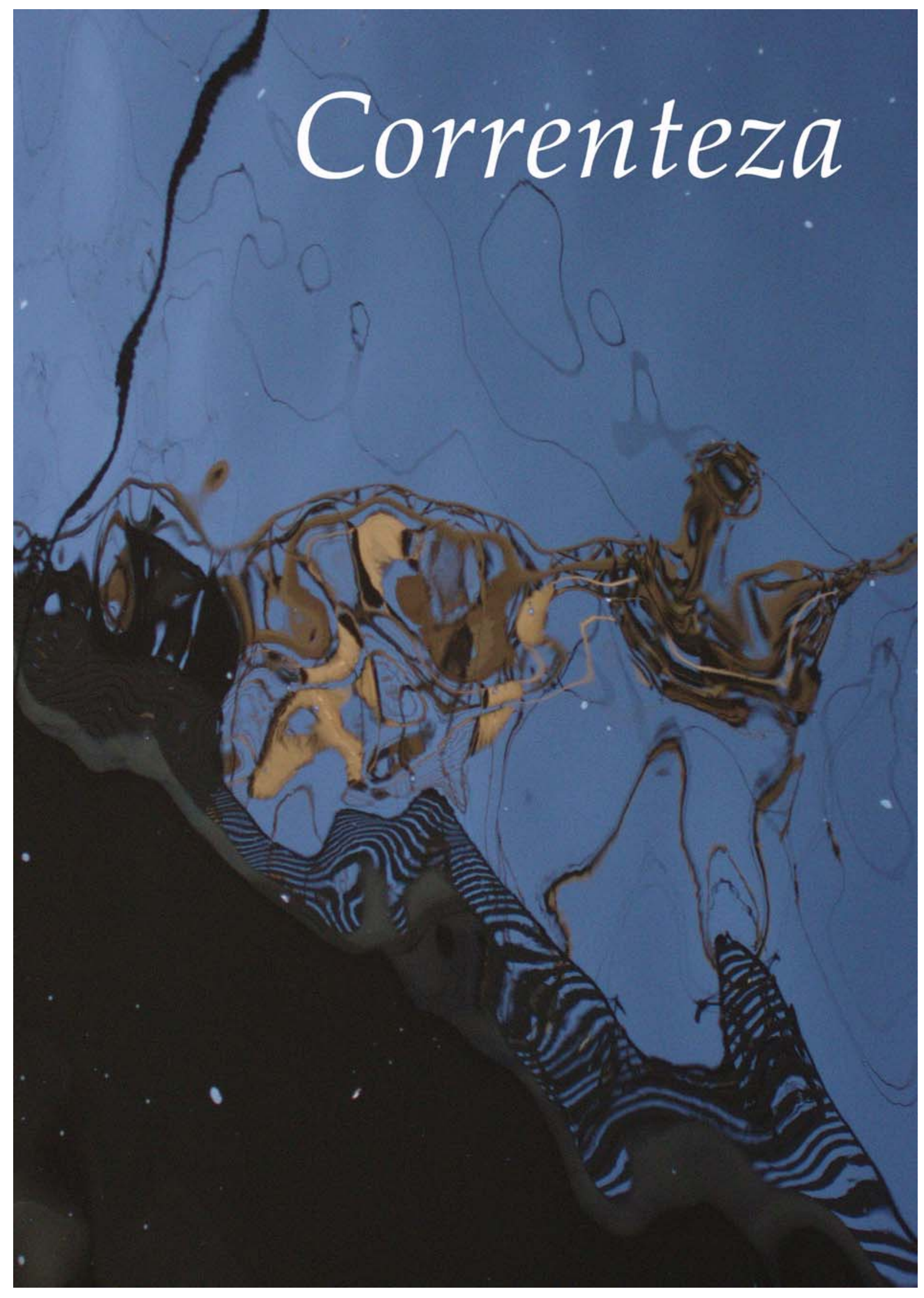




\section{A água como presença na arte contemporânea}

No fundo da matéria cresce uma vegetação obscura; na noite

da matéria florescem flores negras.

Elas já tem seu veludo e a fórmula de seu perfume.

Gaston Bachelard

A partir da segunda metade do século $X X$, muitos artistas passam a romper com os suportes tradicionais da pintura e da escultura, buscando novas alternativas para a utilização da matéria na arte. Não mais condicionada e subjugada pela forma, a matéria passa a ter um significado mais presente que é potencializado por operações conceituais. O surgimento de trabalhos que não se encaixam mais nos gêneros tradicionais, buscando uma maior interação entre a obra, seu entorno e seu espectador, proporciona também o aparecimento de novos materiais na arte. A escolha de materiais fluidos e informes como a água exige uma nova postura criativa dos artistas, que ao invés de buscar o sentido da obra puramente em sua forma, passam a valorizar também os processos efêmeros da matéria e seus conteúdos simbólicos. A presença da matéria caracteriza as instalações, objetos, performances e ações artísticas contemporâneas. Na atualidade, estes novos gêneros artísticos, juntamente com a fotografia, o vídeo e a arte computacional, convivem com a pintura e a escultura. Neste ambiente multimidiático, a tradicional oposição entre presença e representação apresenta-se de maneira mais difusa e complexa, provocando diálogos e interações entre matéria e imagem.

Se a matéria surge como presença significativa na arte contemporânea, esta presença não substitue totalmente a representação como imagem. Além da imagem continuar presente na pintura, mesmo de forma conflituosa e consciente de seu caráter ilusionista, ela também se realiza nos processos fotográficos e eletrônicos. Porém, se na pintura a representação ocorre de maneira essencialmente simbólica e condicionada exclusivamente à habilidade formal e à vontade do artista, na fotografia e no vídeo esta representação depende também da presença material real daquilo que é representado. Embora não se possa considerar o olhar fotográfico como neutro, pois a vontade do fotógrafo dirige certos conteúdos simbólicos, a imagem formada em fotografia e vídeo tem um caráter essencialmente indicial, já que capta a presença da matéria em sua aparição luminosa. A filósofa Taísa Helena Palhares destaca esta particularidade da fotografia segundo o pensamento de Walter Benjamin: "nela há algo que não se reduz ao talento do fotógrafo e não pode se dissolver na arte. É o núcleo que não quer calar ( a centelha do aqui e agora congelada nesta imagem) (...)"24

Este caráter indicial da imagem fotográfica e a sua intensa utilização na arte contemporânea levaram-me a incluir neste capítulo alguns artistas que trabalham 
com fotografia e vídeo juntamente com os artistas que utilizam a água como material constituinte de seus trabalhos. A meu ver, seria incorreto afirmar que um artista que realiza uma videoperformance utilizando água estaria nos apresentando a matéria apenas como tema e representação, e não como matéria. Este suposto artista enfrentou as questões materiais da água da mesma forma que o artista que utiliza água em suas instalações, e embora o produto final de sua arte apresente-se como imagem, a água deixa ali traços de sua presença. Além disso, diversos artistas contemporâneos atuam em suportes diversos, misturando imagem e matéria e confundindo as fronteiras da representação e da presença material. Assim, quando falo sobre água como presença na arte contemporânea, refiro-me não só às obras que apresentam água na sua materialidade final, mas também àquelas cuja presença da água teve parte fundamental em seu processo de criação, mesmo que seu produto final apareça apenas como fotografia ou vídeo.

Apresento a seguir um estudo sobre artistas e obras em que a presença da água é fundamental. Ao invés de buscar um recorte puramente cronológico ou geográfico, optei por apresentar os artistas em seções temáticas, que propõem diálogos entre criadores de diferentes gerações e países. Estas seções não são categorias rígidas, podendo cada artista pertencer a mais de uma delas. Sua aplicação deve ser entendida apenas como uma forma de organizar o pensamento. Determinados artistas utilizam não apenas a água pura, mas misturada a pigmentos e outros produtos químicos ou então substituem a água por outros líquidos que a representam. Por apresentarem bastante proximidade com as questões ligadas à água, incluí-os juntamente com os artistas que utilizam exclusivamente a água pura, separando apenas aquelas obras nas quais os líquidos utilizados contém características simbólicas muito específicas e determinantes, como o sangue e a urina por exemplo. A constância com que a água é utilizada na produção dos artistas analisados é bastante variada de caso para caso. Em alguns artistas como Klaus Rinke, Olafur Eliasson ou Amélia Toledo, a presença da água é bastante recorrente; em outros, como Mário Merz, Kirsten Pieroth e Carlos Fajardo, por exemplo, a água aparece de maneira esporádica, em obras específicas. De qualquer forma, procurei selecionar artistas e obras cuja a contribuição para as poéticas líquidas seja significativa e consistente, independentemente da freqüencia com que utilizaram a água. Certamente não é o objetivo deste trabalho catalogar todos os artistas que utilizaram água, porém creio que o corpo de artistas aqui citado é suficiente para o desenvolvimento de uma reflexão substancial sobre o assunto.

3.1. Água, natureza e sublime 

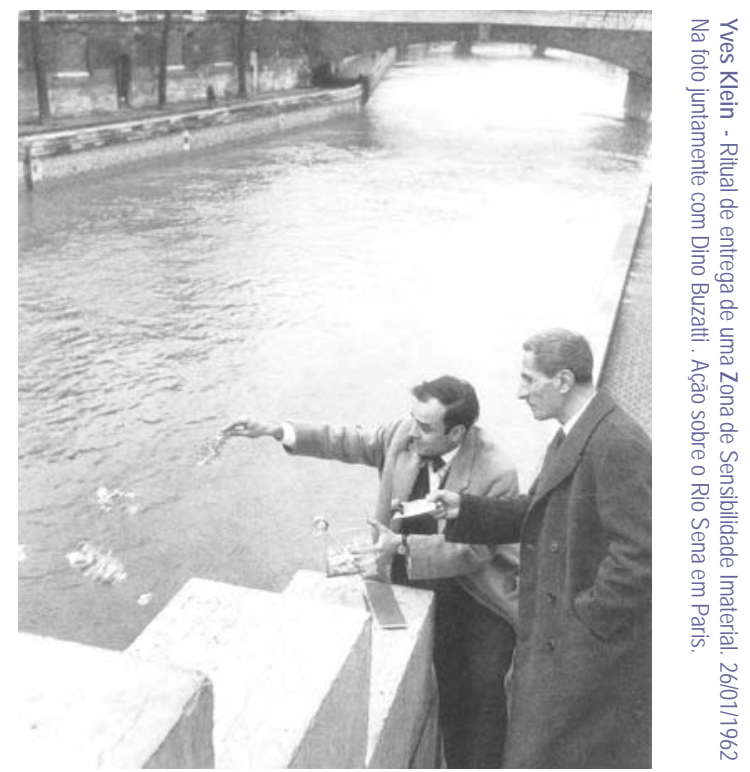

A água como elemento natural transparente e fonte de vida que cobre quase todo o globo terrestre serviu muitas vezes para a simbolização de conteúdos ligados ao sublime. O conceito de Sublime, comforme elaborado por Burke e aprofundado por Kant refere-se à contemplação do infinito evocado pelas forças da natureza e opõese ao conceito de Belo, que se relaciona mais à harmonia das formas e à contenção. O Sublime seria impossível de ser compreendido a partir de conceitos, já que se associaria ao imaterial e ao espiritual. Por almejar o Absoluto, o Sublime contém em sua essência a idéia do inatingível e do irrealizável e representa a pequenez do homem diante da grandeza da natureza.

Os artistas românticos foram os primeiros a se interessar pelo Sublime, e traduziram este conceito em suas pinturas de paisagens grandiosas que retratam uma natureza mística e idealizada. Ao longo da história, o conceito de Sublime foi novamente interpretado pelos expressionistas abstratos americanos, que procuraram criar pinturas que falassem diretamente ao espírito e evocassem sensações imateriais.

A partir da segunda metade do século $X X$ surgem uma série de manifestações artísticas que procuram aproximar arte e vida, buscando uma certa banalização da arte e negando a sua possibilidade de transcendência. A crescente urbanização e a perda da religiosidade parece tornar impossível ao homem contemporâneo a crença no poder místico da natureza, como na concepção dos artistas românticos. Porém, para alguns artistas contemporâneos, ao mesmo tempo que a experiência da arte revela-se banalizada, ela busca paralelamente uma condição transcendente, ainda que limitada e inatingível.

Uma das figuras chaves para o entendimento deste processo é o artista Yves Klein. Sua arte revela-se consciente de seu valor enquanto mercadoria, questiona 
ironicamente seu status comercial e ao mesmo tempo busca uma transcendência. Em seu texto "O jogo duplo de Yves Klein com o Sublime", Thomas Mc Evilley explicita este processo:"graças à sua lendária capacidade de reunir em si impulsos contraditórios, ele pôde ao mesmo tempo abraçar o sublime em toda a sua profundidade, para no próximo momento trazê-lo ao ridículo" ${ }^{25}$.

De 1955 a 1962, Yves Klein utilizou-se diversas vezes das energias da natureza, como o fogo e a água, no questionamento do valor material da arte, assinalando sua fugacidade. Em uma certa manhã, despejou sobre o rio Senna várias folhas de ouro. As folhas colocadas sobre a água eram levadas pela correnteza, reverberando luz e perdendo-se no rio. $\mathrm{O}$ trabalho toma o rio e o vento como forças da natureza mais poderosas do que o simples valor financeiro do ouro que espalha. O dinheiro para a obtenção do ouro provém da compra da obra por um colecionador, numa estranha relação de troca. O trabalho se dá por uma ação produzida pelo próprio ambiente em que se realiza, sendo o artista apenas um facilitador para que a ação aconteça. A fluidez da água do rio assinala a efemeridade da arte e da vida.

Yves Klein realizou também outros trabalhos com água. O artista colocou telas em branco sob a chuva, para que ela deixasse ali as marcas de suas gotas. Novamente aqui as energias naturais agem sobre a obra de arte. A pintura assim produzida busca a fixação do efêmero e se realiza por uma ação bastante prosaica.

Enquanto a atitude de Yves Klein se destaca pela delicadeza, a atuação dos artistas ligados à chamada Land Art impõe-se pelas proporções monumentais.

Dentre os artistas que realizaram trabalhos em rios, mares e lagos, destacam-se os nomes de Robert Smithson, Christo, Peter Hutchinson e Andy Goldsworthy.

O trabalho mais conhecido de Robert Smithson é a Spiral Jet realizada no interior de um lago em Utah, nos EUA. Construindo uma grande espiral com terra e outros materiais no meio do lago, Smithson intervem poeticamente na natureza, proporcionando que o trabalho sofra uma interação entrópica com o ambiente que o cerca. A forma espiralada remete-nos à idéia de desenvolvimento da vida e passagem do tempo, o que é reafirmado pela efemeridade do trabalho. Smithson realizou também a obra Broken Circle, em que criou uma grande intervenção em forma de um círculo cortado sobre um lago na Holanda. O artista possuía ainda projetos para a criação de canais d'água serpenteantes que não foram realizados.

Christo realiza também um trabalho em que envolve três ilhas com uma enorme superfície de plástico cor-de-rosa que bóia sobre a água. A flutuação do plástico, bem como a sua intensa cor artificial, parecem destacar as ilhas da paisagem. A enorme escala da intervenção faz as ilhas parecerem pequenas, como se fossem 
flores flutuantes, adquirindo uma aparência incomum e ao mesmo tempo atraente e chocante. Embora relacionem-se com o sublime e tenham sido compreendidas como reflexões sobre a natureza por certos críticos, as obras de Christo e Smithson na verdade pouco tem de ecológicas, devido à profunda interferência que causam no meio ambiente.

Outra artista ligada ao grupo de artistas da Land Art americana, que também realizou trabalhos com água é Nancy Holt. Em 1974, Nancy Holt, que foi casada com Smithson, realizou a intervenção Hydra's Head, em que construiu seis pequenos reservátorios circulares ao longo das margens do rio Niagara, que ocupavam posições correspondentes à constelação Hydra. Nancy Holt realizou, na década de 80 , projetos de renaturalização, que punham a arte à serviço da preservação da natureza. Além de Nancy Holt, diversos outros artistas desenvolveram projetos a partir desta época que tinham como objetivo a preservação da água, e associavam-se a grupos de arquitetos e engenheiros ambientais. Entre estes artistas encontram-se Patricia Johnson, Viet Ngo e Simpson.

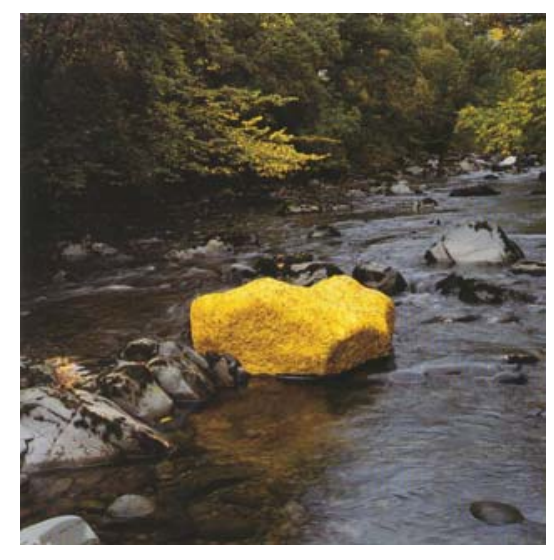

Entre os artistas de origem inglesa, os projetos de intervenção sobre a natureza apresentaram-se de maneira menos heróica e mais singela. Ao invés da introdução de materiais estranhos à natureza em escala monumental, artistas como Andy Goldsworhy e Peter Hutchinson agiram de forma mais suave, realizando intervenções bastante efêmeras.

Andy Goldsworthy trabalha com os materiais coletados na própria natureza, como folhas, flores e galhos. Algumas de suas intervenções são feitas em rios e riachos, nos quais o artista "encapa" pedras imersas na água ou árvores com folhas e flores em cores naturais vibrantes. Em outras intervenções o artista simplesmente tinge com pigmentos naturais a água que se acumula no interior de poças entre as pedras, criando um jogo cromático de grande beleza.

Andy Goldsworthy desenvolveu também diversas esculturas com gelo e trabalhos realizados com pedras e gravetos na beira da praia, que eram desmontados pela força das águas, quando a maré subia. Atuando como um organizador da matéria natural, Goldsworthy realiza trabalhos extremamente poéticos e efêmeros, que, sem dúvida, evocam o sublime e a delicadeza da natureza. 
Peter Hutchinson é talvez um dos únicos artistas a ter realizado intervenções submarinas. Em 1969 o artista construiu pelo menos três trabalhos sob as águas do mar. Em delas o artista plantou um triângulo de flores amareladas no fundo do mar, em outra ele construiu diques submarinos sacos de areia e na terceira ele prendeu em uma corda uma série de cabaças atadas que foram fixadas sobre o chão marítimo. As intervenções puderam ser vistas pelos espectadores através de fotos que documentavam a ação.

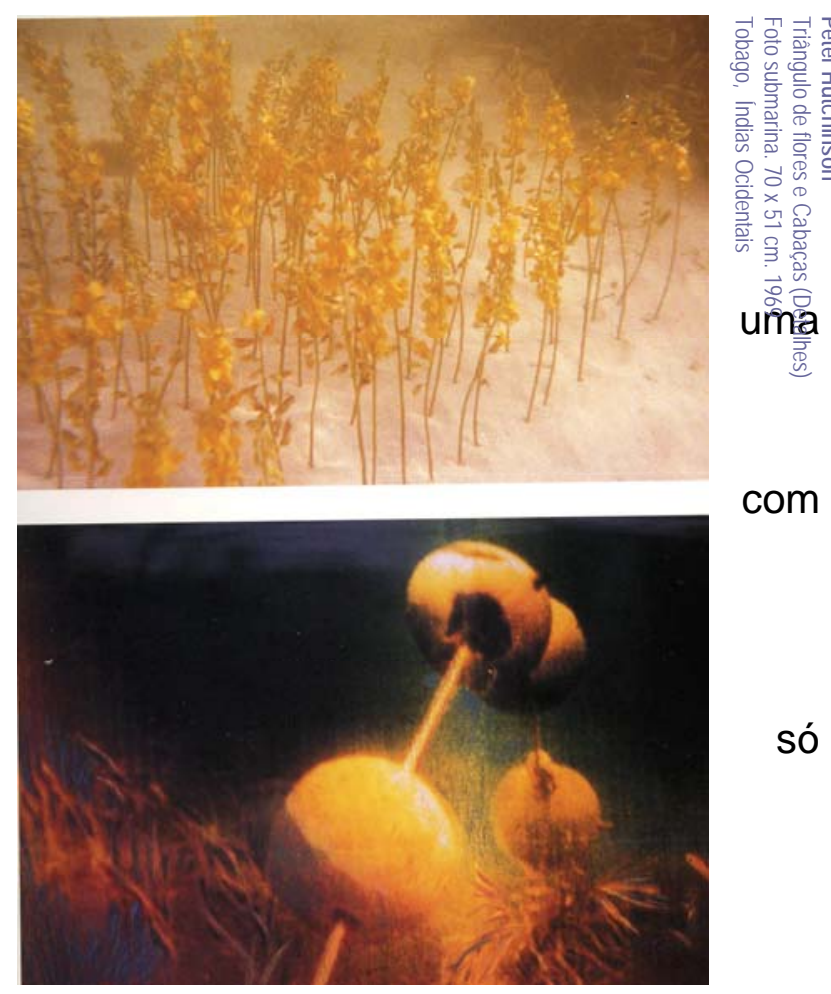

Outros artistas ingleses realizaram ações nas quais a água desempenha um papel importante. Na ação Waterlines, Richard Long caminhou por Portugal e Espanha durante 20 dias e meio, entre as costas do mar Mediterrâneo e do Atlântico, derramando água de garrafas, traçando assim linhas d'água sobre o chão. O artista Barry Flanagan realizou uma ação na qual criou um "furo n’água", introduzindo um cilindro de acrílico no meio do mar, que era aos poucos encoberto pela maré. A ação foi documentada em vídeo. As imagens, filmadas de cima, mostram uma superfície quase abstrata formada pelas águas e um círculo em seu interior, onde parece haver um movimento diferente daquele existente na água ao redor. Somente ao final do vídeo o observador pode compreender como a ação se desenvolveu.

Se a idéia de sublime pode ser facilmente relacionada às obras que interferem diretamente sobre a natureza, devido a suas proporções desmedidas ou ao seu caráter efêmero, este conceito merece outra interpretação no trabalho de artistas como Michael Craig-Martin e James Turrell, que utilizaram a água fora de seu ambiente natural e de maneira mais conceitual ou minimalista. Nestes casos, a água aparece mais como um elemento em si, dissociado de sua origem natural e relacionado à idéia do vazio, que em última instância remete à espiritualidade.

No trabalho "Um Carvalho" (An Oak Tree), Michael Craig-Martin coloca um copo com água sobre uma prateleira de vidro em uma altura elevada, e, ao lado, ao nível dos olhos, é colocado um texto sobre uma placa de vidro onde se lê uma espécie de entrevista do artista dizendo que transformou o copo d'água em um carvalho. No texto ele afirma que embora a obra tenha a aparência de um copo d'água ela é 
verdadeiramente um carvalho. Através desta atitude irônica e aparentemente absurda, o artista faz-nos pensar que a arte depende apenas de acreditarmos nela para tornar-se arte. Se acreditamos que o copo d'água é um carvalho, ele pode ser. Da mesma maneira, o discurso que se faz sobre a arte é também incorporado à arte. Se um objeto não gera uma discussão, então ele não pode ser considerado uma obra de arte. Para Craig-Martin o que importa é o conceito da obra, e não suas condições de aparência visual. Entretanto, o fato de ele ter escolhido um copo d'água colocado em uma altura elevada, gera uma certa adoração da obra, remetendo a idéias vinculadas a questão da fé. $O$ aspecto critalino e transparente do copo d'água cria um certo mistério e ao mesmo tempo afirma um certo vazio, já que não possui nenhuma relação direta com o carvalho. A natureza aparece aqui apenas como ausência e o trabalho apresenta-se de forma dúbia, já que por um lado afirmase ironicamente através de um objeto banal e por outro lado incita à fé e à espiritualidade.

A idéia de vazio é também explorada pelo artista James Turrell, que trabalha freqüentemente com luz. Em um de seus trabalhos, o artista criou um ambiente luminoso no interior e ao redor de uma piscina. O espectador tem que mergulhar na piscina para vivenciar a obra e as luzes da instalação mudam de cor, alterando a percepção. O ambiente é extremamente vazio, de arquitetura minimalista e o trabalho convida o espectador à contemplação silenciosa das vibrações luminosas produzidas pelos reflexos aquáticos. Os trabalhos de Turrell são concebidos como espaços destinados à meditação e à interiorização espiritual e realizam-se através de recursos quase imateriais. Sua busca do sublime é destacada por diversos comentadores e está menos ligada aos estereótipos das paisagens naturais e mais às energias primárias do mundo sensível, mesmo que estas energias sejam reconstituídas artificialmente e ganhem formalizações mais abstratas.

$\mathrm{Na}$ arte brasileira, o interesse pela água e a sua associação a uma certa espiritualidade aparece sobretudo no trabalho da artista Amélia Toledo. Em seu trabalho, a água como tema e matéria aparece com bastante constância e as paisagens naturais são parte fundamental de sua poética. $O$ trabalho de Amélia é marcado pela escolha de materiais transparentes e pela criação de situações lúdicas a partir das energias materiais. Seu trabalho é povoado de referências à água, quer seja na sua utilização propriamente dita como matéria, quer seja como alusão temática aos elementos líquidos naturais.

Na série "Frutos do Mar", realizada de 1974 a 1982, por exemplo, a artista coleciona conchas e outros materiais de origem marítima, inserindo-os juntamente com conchas confeccionadas em resina transparente e cristais em vidros com água, criando pequenos mundos líricos que fazem referência ao fundo do mar. Em alguns 
trabalhos, Amélia submergiu no mar peças em resina e vidro por longos períodos de tempo até que eles fossem incorporando cracas e corais e sendo corroídos pelo ambiente marítimo. A natureza atuava como formalizadora do trabalho.

Em outras obras com líquidos, o que se destaca é seu lado lúdico. O trabalho "Glu Glu" consiste de uma espécie de ampulheta de vidro cheio de líquido roxo. Ao ser aquecido pelo calor da mão de quem o manipula, o líquido se expande e se movimenta pelo vidro. Em seus "Discos Táteis", Amélia acondiciona líquidos coloridos em peças planas e circulares de plástico que podem ser tocadas, modificando sua aparência visual pelo deslocamento do líquido.

Suas "Bolas-Bolhas" são esferas de plástico transparente preenchidas de espuma de sabão que devem ser manipuladas. Ao interagir com elas, o espectador cria bolhas dentro de bolhas, visualizando a natureza delicada de suas membranas e vivenciando a experiência lúdica efêmera.

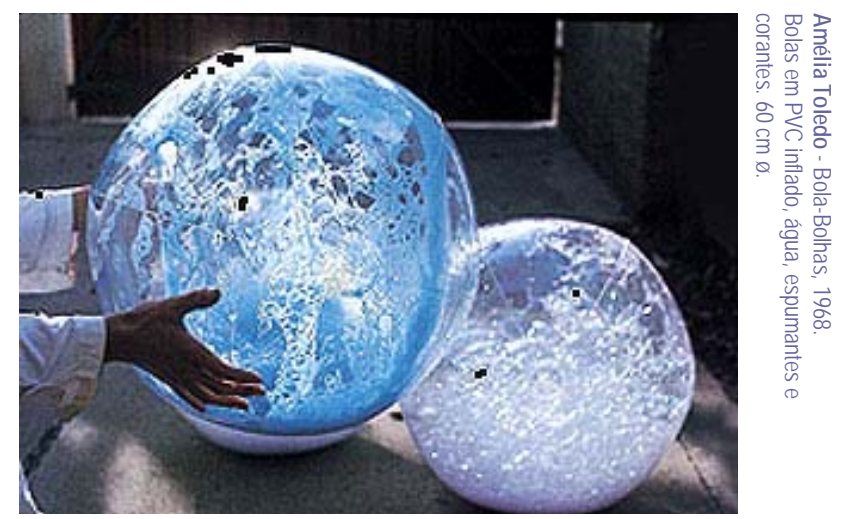

Mesmo quando não utiliza líquidos, a água surge como referência poética para Amélia Toledo, como por exemplo na escultura em metal "Sete Ondas" instalada na frente do MAM - São Paulo ou na escultura "Poço" realizada em metal, vidro e resina e pertencente ao acervo do MAC-USP. 
Entre os artistas que ganham destaque principalmente nas décadas de 80 e 90 está a artista Roni Horn. O interesse pela água e uma atitude que se aproxima do minimalismo pode ser verificado em diversos de seus trabalhos, como o seu Dictionary of Water, livro de fotografias, nas quais ela documenta durante cerca de um ano as diferentes aparências das águas do rio Sena. Em outra série de fotografias, Roni Horn capta o rosto de uma jovem em uma piscina com pequenas alterações de luz , constituindo uma documentação da fluidez do tempo. Roni Horn realiza também um trabalho sonoro no qual declama suas impressões e sentimentos a respeito da água.

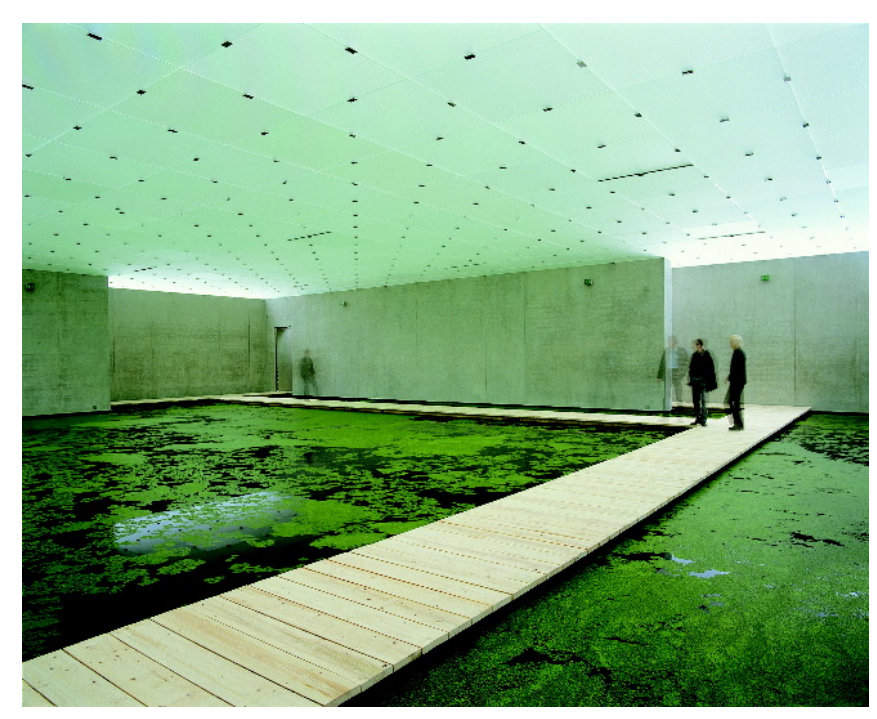

Um dos artistas internacionais que mais tem trabalhado com água e com as relações entre arte, sublime e natureza é o dinamarquês Olafur Eliasson. Este artista realiza instalações em que a natureza é recriada através de um aparato tecnológico artificial, que é muitas vezes incorporado à apresentação visual da obra. Além de diversos trabalhos realizados com luz, Eliasson possui obras feitas com água, vento, plantas, terra cristais e espelhos.

Na exposição The Mediated Motion, realizada na Áustria, Eliasson preenche um dos ambientes de um museu de arquitetura modernista com água e plantas aquáticas, criando uma passarela por onde os espectadores devem transitar. Em outro ambiente, a sala é totalmente preenchida por uma névoa vaporosa, e o visitante é obrigado a atravessar o espaço pisando em um ponte de madeira suspensa. Neste e em outros trabalhos de Eliasson, observa-se um diálogo entre natureza e civilização, que coloca em atrito a beleza sublime dos elementos naturais com a sua desencantada reconstrução artificial no interior da arquitetura.

Em uma instalação realizada diretamente sobre a natureza, Eliasson constrói uma grotesca estrutura de canos de ferro sob a qual é montada uma cachoeira artificial, que por um mecanismo técnico faz com que a água suba de um degrau para outro, ao invés de cair em seu fluxo natural. No trabalho Your Strange Certainty Still Kept, realizado em 1996, o artista cria uma chuva artificial no interior de uma galeria iluminada por luzes estroboscópicas, congelando assim a imagem das gotas de chuva no ar. 
Entre os trabalhos mais conhecidos de Olafur Eliasson estão as intervenções que ele realiza com pigmento verde sobre diversos rios. O artista tinge rios dos Estados Unidos, Suécia, Alemanha e outros países com pigmentos não nocivos à natureza utilizados por cientistas para marcar as correntes marítimas. A estranha cor verde fosforescente destes rios, por um lado remete a uma exacerbação das belezas naturais, por outro lado surge aos olhos como extremamente artificial. Se na contemporaneidade a contemplação do sublime da natureza idealizada dos românticos tornou-se impossível, Eliasson atualiza esta questão introduzindo um sublime artificial que surge como crítica à distância do homem atual do mundo natural e à institucionalização da arte.

Enquanto Eliasson interessa-se pela natureza e seus fenômenos e a visualiza de maneira domesticada e harmônica, sugerindo um certo distanciamento plácido associado ao temperamento nórdico, o artista brasileiro Nuno Ramos apresenta-nos uma natureza metafórica trágica e devoradora em que tudo parece desmoronar e sucumbir às suas próprias forças matéricas. Para Nuno Ramos, o mundo natural não se diferencia do ambiente social, mas se interrelaciona com ele, devorando-o e sendo devorado por ele.

Em uma ação performática filmada em vídeo, Nuno instala uma série de móveis antigos em uma praia, deixando-os afundar na areia úmida até serem levados pela maré. Uma certa fragilidade da matéria e da memória é colocada à prova diante da fluidez irrascível do tempo e do poder das forças naturais. A água do mar exibe o seu poder destruidor e funciona como metáfora para a transformação e a morte. No trabalho de Nuno Ramos os elementos materiais os objetos presentes não representam apenas a si mesmos e seus processos, mas são inseridos em uma intrincada rede de relações poéticas e simbólicas, que ultrapassam a discussão das questões da natureza.

$\mathrm{Na}$ instalação "A morte das casas", o artista cria uma chuva artificial que desce pelo alto vão livre espaço expositivo ao som de um poema declamado em voz alta. Diferentemente da chuva artificial de Olafur Eliasson, a chuva de Nuno Ramos não se serve à pura observação de seu fenômeno, mas encarna metaforicamente a

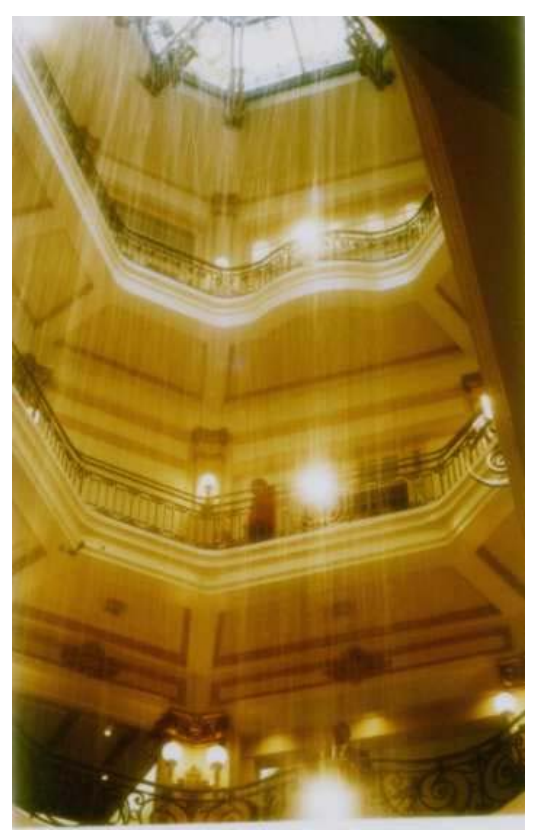

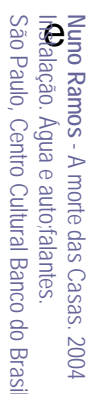
do sensação da desproteção e introduz uma certa precariedade ameaçadora ao espaço imponente do Centro Cultural Banco do Brasil. A chuva é também o assunto do vídeo em que Nuno Ramos dispõe pela cidade placas de vidros com palavras que se 
dissolvem perante a tempestade noturna. A água aparece no trabalho de Nuno Ramos também na instalação „Vai Vai“ para matar a sede dos burros que carregam pesadas caixas de som no espaço expositivo ou no trabalho „Entre a água do mar e o vinagre", em que estes dois materiais circulam por mangueiras colocadas entre esculturas de vidro.

Mesmo em alguns trabalhos de Nuno nos quais a água não aparece como matéria, pode-se notar sua presença como tema, como é o caso da obra "Craca", uma escultura em alumínio que explora idéia de um leito arrancado de um rio, onde estão incrustados peixes, conchas e outros animais tragados. O interesse de Nuno Ramos pelos líquidos não se resume à água, pois o artista utiliza também com bastante freqüência o óleo e a vaselina líquida. Embora possa ser exagerado afirmar que Nuno Ramos busca em todas suas obras a experiência do sublime, as idéias de descontrole ameaçador, da matéria informe e do poder destruidor das forças materiais remetem a várias questões que se aproximam deste conceito.

$\mathrm{Na}$ produção mais recente da arte brasileira, iniciada a partir dos anos 90, será possível citar o meu próprio trabalho pessoal como artista e o trabalho da artista Flávia Vivacqua. Em meu trabalho pessoal a água aparece com grande constância e o interesse pelo sublime e pela natureza verifica-se sobretudo nos aquários que recriam paisagens flutuantes ou nas instalações que têm como tema os rios ou horizonte. A análise de meu trabalho pessoal será melhor detalhada no capítulo seguinte desta tese.

No trabalho da artista Flávia Vivacqua a água aparece em pequenas bolsas de plástico que se articulam construtivamente como células de um mesmo organismo. A artista dispõe várias destas bolsas de material transparente lado a lado, compondo instalações quase minimalistas, que possuem porém uma vida interna, já que no interior destas bolsas a água evapora e se condensa.

Em outros trabalhos a artista realiza intervenções com bolhas de ar acondicionadas em plástico, que são lançadas ao céu nas proximidades do mar. As relações entre arte e natureza são o ponto central da produção de Flávia Vivacqua, cujo interesse foca-se nas questões do efêmero e da ecologia.

O trabalho dos artistas até aqui apresentados têm como base a discussão da natureza. A questão da paisagem aparece de maneira mais ou menos freqüente em suas trajetórias e em muitas delas é possível encontrar uma relação com o conceito de sublime. Este conceito não se restringe porém estritamente às proposições históricas de seus primeiros pensadores, como Burke e Kant, mas deve ser 
atualizado para as condições do presente, recebendo todas as ampliações e limitações que esta atualização exige. Embora exista uma certa dose de idealismo em muitos dos trabalhos aqui citados, ele diferencia-se da paixão romântica histórica, muitas vezes tendo consciência das dificuldades de transcendência da arte na contemporaneidade.

A presença da água nestas obras reforça seus conteúdos sublimes, ora por sua associação à natureza e à espiritualidade, ora pelos seus fenômenos físicos, como a transparência, a forma informe e a reflexibilidade, que remetem à idéia da imaterialidade. 


\section{2. Água, fenômeno e processo}
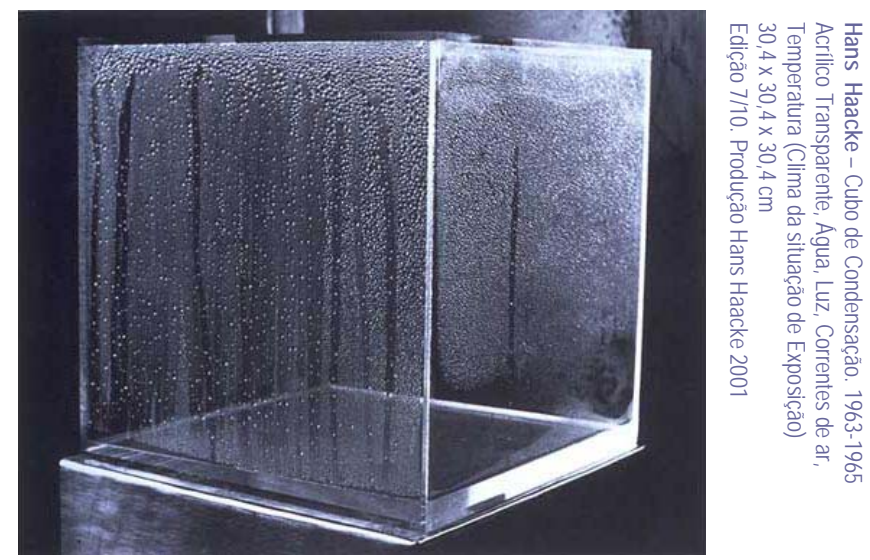

Os fenômenos característicos do meio aquático, como a transparência, a fluidez, a forma informe, a reflexão e a flutuação servem como matéria para o trabalho de diversos artistas contemporâneos. Para diversos destes artistas, a água, antes de ser vista como um elemento pertencente à paisagem natural carregado de conteúdos simbólicos, é observada prioritariamente em seus aspectos fenomenológicos mais puros, como um material em si, evitando-se as formulações mais narrativas. São sobretudo os processos ocorridos nos meios líquidos e sua percepção pelo espectador que interessam a estes artistas. Não se pode afirmar que os artistas que apresento a seguir formem uma categoria coesa e isolada do grupo de artistas que apresentei anteriormente. Em muitos deles os procedimentos narrativos e a associação entre água e paisagem também estão presentes; da mesma forma, os artistas ligados à simbolização da natureza sublime não descartam a observação dos aspectos fenomenológicos da água. A razão da apresentação destes artistas em diferentes grupos justifica-se apenas para identificar tendências, que não são auto-excludentes, mas complementares. O leitor poderá concluir que este ou aquele artista poderia se encaixar em outra categoria.

Uma das primeiras vezes que a água aparece no cenário das grandes exposições internacionais de arte é no trabalho do artista japonês Sadamasa Motonaga do grupo Gutai, apresentado em 1956 na Bienal de Veneza. Ao longo de uma alameda, o artista pendurou diversas folhas de plástico transparente com água e pigmentos coloridos, que foram presas às copas das árvores. O trabalho estava sujeito às alterações de luz e temperatura do ambiente externo e pendia para baixo pelo peso da água. Embora a forma dos plásticos pudesse lembrar as gôndolas de Veneza, o trabalho não se articulava através de elementos figurativos narrativos, e sim a partir da experimentação da matéria líquida em conjunção com o plástico oriundo da produção industrial.

A reunião de materiais industrializados juntamente com elementos naturais foi também o que caracterizou o trabalho dos artistas italianos ligados à Arte Povera. 
Os processos de transformação dos materiais aliados à discussão de aspectos da cultura e da história foram os principais motes do movimento Arte Povera. Suas construções apresentavam uma estruturação precária, apoiada na utilização de materiais de pouco valor artístico até então, que eram porém investidos de grande potência poética. Esta precariedade opunha-se ao crescente tecnicismo da sociedade e pode ser entendida como um contraponto europeu à frieza do minimalismo norte-americano.

Diversos destes artistas utilizaram água em suas criações. Em 1966 Pino Pascali expõe o trabalho „Cerca de $32 \mathrm{~m}^{2}$ de Mar“, em que dispõe sobre o chão 32 caixas de alumínio, com um metro quadrado cada, cheias de água salgada. Luciano Fabro realiza o trabalho Giordano Bruno (1975) no qual insere pedaços de resina incolor em grandes bacias de vidro com água, criando uma associação de materiais transparentes. Mario Merz construiu uma grande plataforma de ferro que atravessa um de seus igloos de vidro, e em sua ponta prendeu uma torneira que pinga incessantemente em um balde. Um sistema de circulação com uma mangueira faz com que a água retorne de maneira cíclica. A enorme espacialidade do igloo envidraçado e sua transparência são como que materializadas pelo pingar incessante da água.

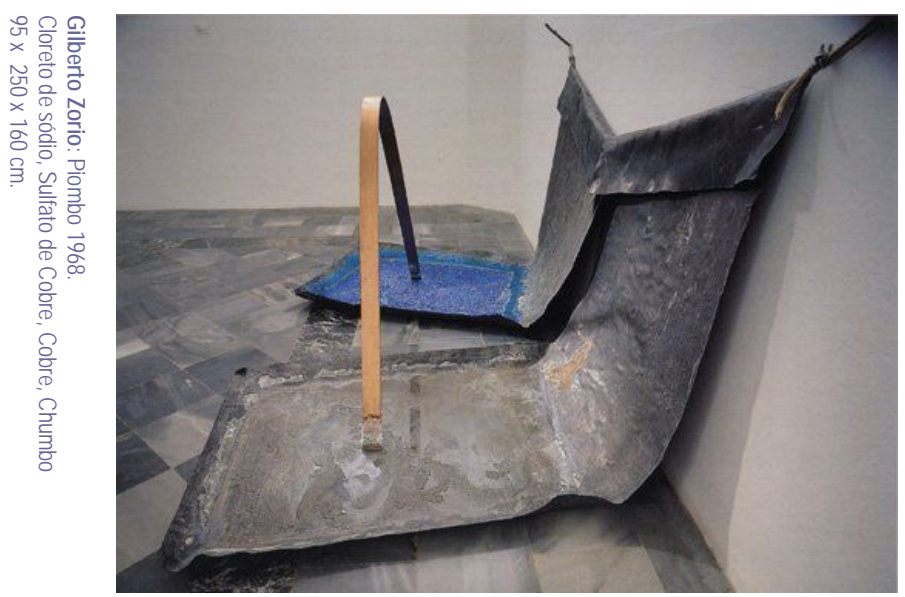

Gilberto Zorio realizou uma série de trabalhos em que utiliza líquidos como água ou ácido colocados em recipientes de ferro, tensionando outros materiais pelo peso ou pela corrosão. Os processos alquímicos interessam a este artista, em cujas obras os materiais aparecem freqüentemente em transformação.

Giuseppe Penone constrói uma pequena piscina no meio de um riacho, interrompendo seu fluxo e criando uma superfície quadrada plana e cristalina.

Pier Paolo Caozolari cobre diferentes objetos por uma fina camada de gelo produzido por equipamentos de refrigeração. Em todos estes trabalhos, a água aparece como força dinâmica e transformadora, atuando a partir de seus processos físico-químicos e ópticos. A natureza irrompe de forma poderosa frente aos materiais industriais, evocando por vezes um passado histórico orgânico, que atua e modifica o presente.

A observação dos processos físico-químicos da água aparece também nos trabalhos da década de 70 realizados pelo alemão Hans Haacke. No trabalho 
Kondensationswürfel (Cubo de condensação) Haacke acondiciona em uma caixa de acrílico transparente uma pequena quantidade de água, que conforme a temperatura, ora se condensa nas paredes do cubo, ora escorre sobre elas. Haacke cria também outras caixas de acrílico com água e ar, que podem ser manipuladas pelo espectador. No trabalho Rheinwasseraufbereitungsanlage (Estação de tratamento de água do Reno), o artista problematiza questões ligadas à ecologia e à entropia. Neste trabalho Hans Haacke coleta água poluída do Reno e através de tratamento químico consegue clarificá-la e limpá-la introduzindo-a em um grande aquário onde nadam peixes, onde antes seria impossível. Ao expor a água tratada ao lado da água poluída original, Hans Haacke resgata os significados da água como fonte de vida e como material representante da limpeza e da clareza cristalina. Apesar da ação conceitual prevalecer sobre a busca formal neste trabalho, não se pode deixar de notar a qualidade estética atingida ao confrontar os diferentes graus de transparência da água ou mesmo a beleza poética da inserção dos peixes que nadam no grande aquário.

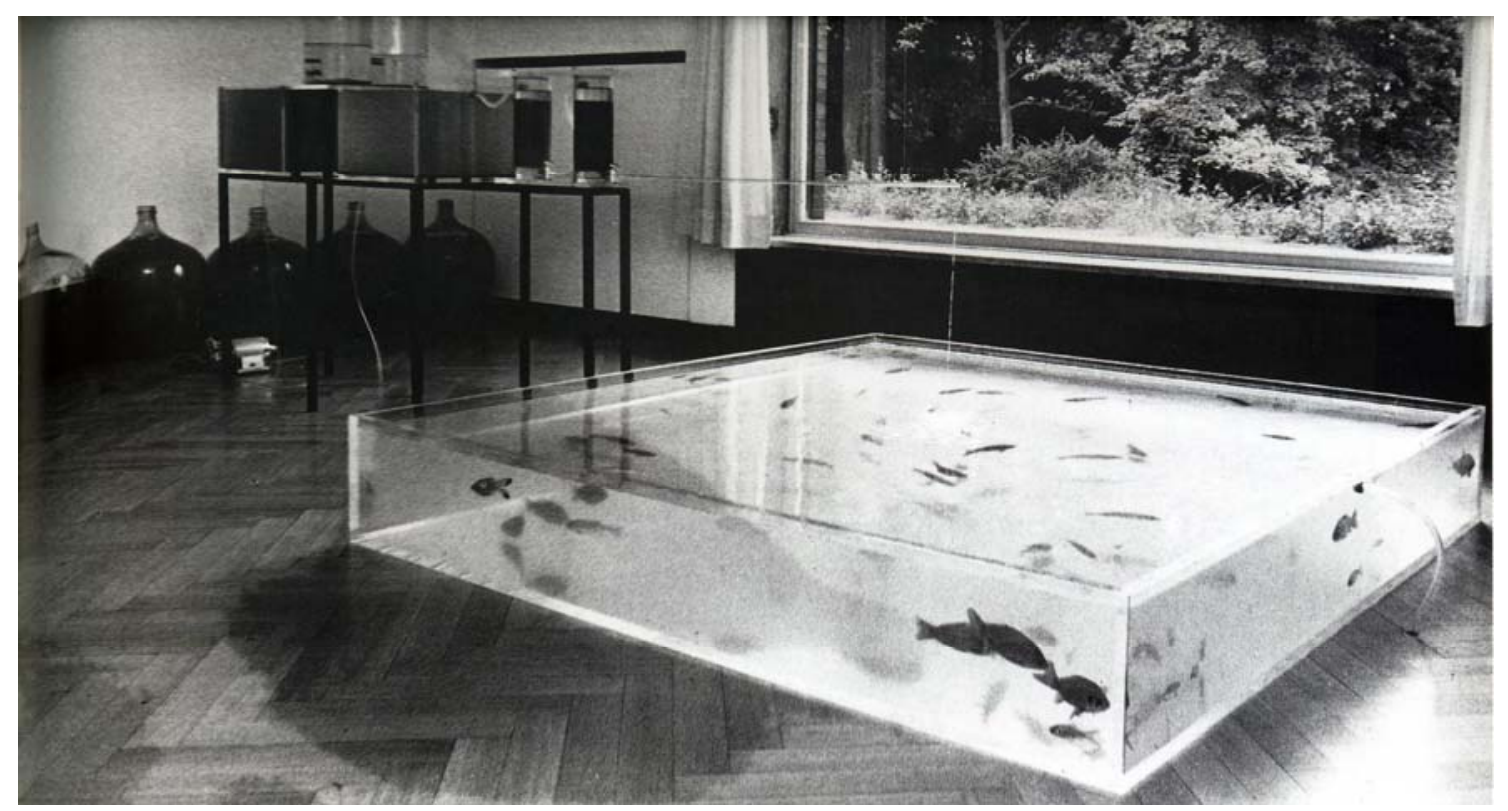


Um dos artistas que mais utilizou a água como matéria para seus trabalhos foi o alemão Klaus Rinke. Em uma trajetória que inclui muitas esculturas, instalações $\mathrm{e}$ performances, Rinke utilizou a água tanto em seus aspectos simbólicos como em seus aspectos físicos. Em vários trabalhos, ele apresenta grandes tonéis devidamente etiquetados com água proveniente de diversos mares e rios. A reunião de água de lugares tão distantes parece conferir uma impressão de totalidade
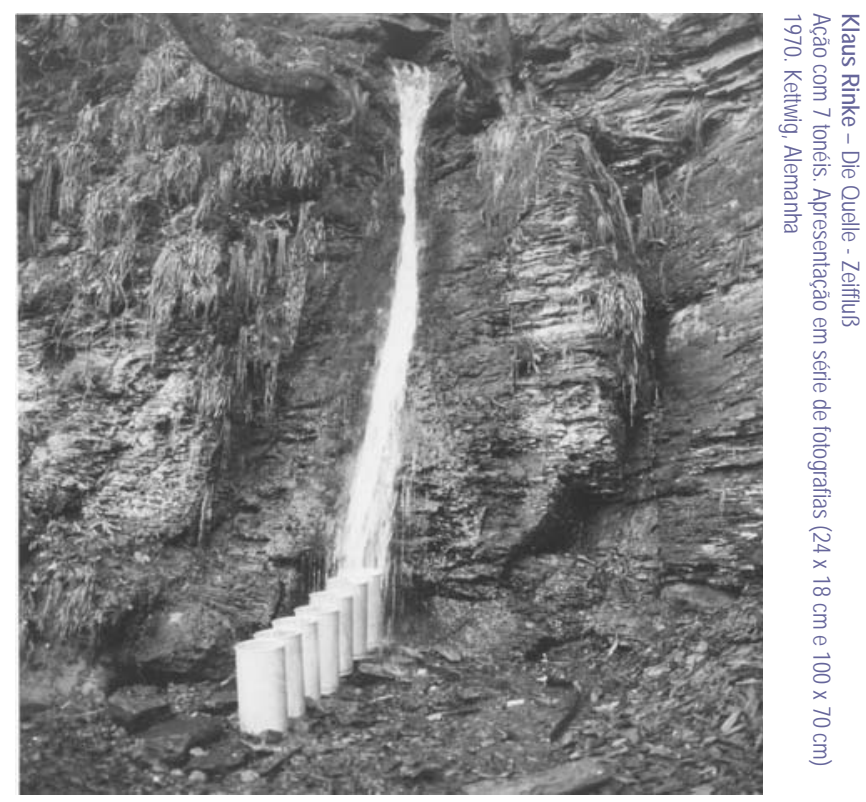
entre os povos e o ambiente que os cerca. O processo de coleta da água também é incorporado à significação do trabalho. Em alguns casos, o artista confeccionou grandes conchas para coletar a água dos rios e mares. Estas conchas são expostas juntamente com fotos da coleta, ao lado dos tonéis com água. No trabalho Die Quelle - Zeitfluß (A Nascente - Fluxo de Tempo), Rinke coloca uma série de tonéis enfileirados sob uma cachoeira durante um determinado tempo. Os tonéis mais próximos da cachoeira recebem mais água que os distantes e o trabalho funciona como uma espécie de medição do tempo nos processos naturais.

Klaus Rinke também utilizou a água em uma série de performances. No trabalho Atlantis ele coloca um tonel com água quase até a boca no meio da rua e depois entra lentamente neste tonel. Posteriormente ele abaixa-se rapidamente até desaparecer dentro do tonel. Ao abaixar-se uma grande quantidade de água é espirrada para fora, como resultado de sua ação. Ao final, Klaus Rinke levanta-se novamente, já totalmente molhado e transformado pela ação. A beleza poética do trabalho consiste em observar a extrapolação do limite da superfície da água e o seu retorno ao estado de repouso. O fluxo de tempo, a percepção do espaço e as manifestações físicas provocadas pela interferência do homem sobre os elementos naturais são as questõs principais levantadas por seu trabalho.

Klaus Rinke realizou ainda uma série de outros trabalhos nos quais as questões de peso e leveza nos ambientes líquidos são enfocadas pela utilização de elementos que bóiam e afundam. Colocados em longos vidros com água, os pesos são presos a peças que bóiam através de cabos de aço. A tensão entre o leve e o pesado estica o fio de aço, garantindo sua verticalidade. A limpeza visual do trabalho nos conduz à contemplação da superação da lei da gravidade ocorrida no meio líquido. 
A utilização de água em atitudes performáticas e trabalhos que possuem caráter efêmero é também verificada na produção do artista suíço Roman Signer. Em uma destas ações o artista cria uma fonte circulante em um pequeno veículo que se desloca para diferentes pontos da cidade. A fluidez da água parece equivaler ao tempo efêmero em que a fonte permanece no mesmo lugar. No trabalho de Signer, os processos fugazes ocorrem geralmente acompanhados de uma atitude irônica. Por vezes as ações do artista chegam a lembrar algumas atitudes de Yves Klein, por encontrarem uma simpatia com o Sublime, mas suas proposições engraçadas e absurdas parecem mais desacreditadas do que as de Klein. Em uma de suas esculturas o artista constrói uma série de canais de metal com água, que tocam as paredes da sala, atravessando-a e cruzando-se em seu centro. No interior destes canais o artista coloca um caiaque, no qual ele rema em busca de uma saída, porém sem poder escapar às barreiras do espaço da sala. Signer realiza também uma série de trabalhos com explosivos, com os quais faz voar para o alto latas cheias de água, pó e outros materiais.

O interesse fenomenológico pela água também se faz presente nas obras de artistas brasileiros que marcaram a década de 70 e continuam atuantes até hoje, como José Resende, Carlos Fajardo e Waltércio Caldas. trabalho de José Resende exposto na XXIV Bienal é um bom exemplo. Neste trabalho "um tubo de vidro cheio de mercúrio, vaselina líquida e água destilada, flutua dentro de outro tubo, de mesma forma porém muito maior (da altura de uma pessoa), que contém também vaselina e água. Os líquidos por suas densidades diferentes não se misturam existe entre eles uma nítida linha demarcatória." ${ }^{26}$ O tubo maior apresenta-se preso inclinado à parede através de fios plásticos, pendendo para a frente. A tensão a que o trabalho é submetido pela força da gravidade parece representar uma certa ameaça ao vidro e ao derramamento dos líquidos. Os processos de flutuação e transparência obtidos pelos meios líquidos remetem-nos a uma poética dos materiais, que ao mesmo tempo que se repelem, encontram um frágil equilíbrio. A presença do ar e de diferentes líquidos transparentes criam um mundo de sutilezas, em que os limites dos materiais são demarcados por linhas de horizonte incertas, confundindo-nos a percepção. 
Em um trabalho mais recente, de 2002, José Resende realizou uma grande escultura com três calotas de ferro preenchidas com água que eram presas a tubos de cobre e interligadas entre si. A água, além de oxidar o ferro que a continha, deixando marcas de sua presença, tinha também a função de estabilizar a peça, lidando novamente com a variável peso. Em sua atitude contida, em que a metaforização e a narração são substituídas pelo tensionamento e pela ação física dos materiais, Resende realiza trabalhos de grande beleza poética e elegância formal.

A mesma recusa à narratividade pode ser encontrada no trabalho de Carlos Fajardo. Sua escultura instalada na frente do MAM-SP consiste de quatro chapas de ferro colocadas ao nível do chão com um pequeno vão central de onde jorra água. $A$ quase ausência de volume da escultura, sua planaridade e simplicidade formais, são quebradas pela intervenção sutil da água que escorre sobre ela. A rígida geometria plana de suas placas de ferro retangulares é perturbada pela organicidade da água que segue seu caminho livremente. A quase invisibilidade da escultura busca evocar o silêncio e o vazio e pede uma observação atenta às sutilezas.

Em outra série de trabalhos, Carlos Fajardo toma blocos de pedra e cava depressões neles de modo a servirem como recipientes que ele preenche com água. Os blocos de pedra são colocados sobre pequenos suportes cônicos, fazendo com que fiquem um pouco elevados do nível do chão. A transparência e leveza da água contrapõem-se ao peso e opacidade da pedra. Buscando evidenciar o vazio e a presença dos materiais como "coisa em si", Fajardo preenche com o líquido transparente e incolor, o espaço de ausência de matéria que provocou na pedra.

Waltércio Caldas também possui trabalhos em que utiliza líquidos. Um deles é uma escultura de parede em finos tubos de vidros curvados preenchidos até praticamente a metade com água. A escultura passa um aspecto de fragilidade e delicadeza, acentuado pela maneira que se projeta no espaço como uma estrutura oval transparente. A água em seu interior cria uma linha horizontal em sua superfície, interferindo sutilmente na aparência da escultura.

Laura Vinci vem realizando trabalhos contundentes em a água é incorporada em diferentes estados físicos: a evaporação no trabalho "Mona Lisa" apresentado no Centro Cultural São Paulo e trabalho „Warm White“

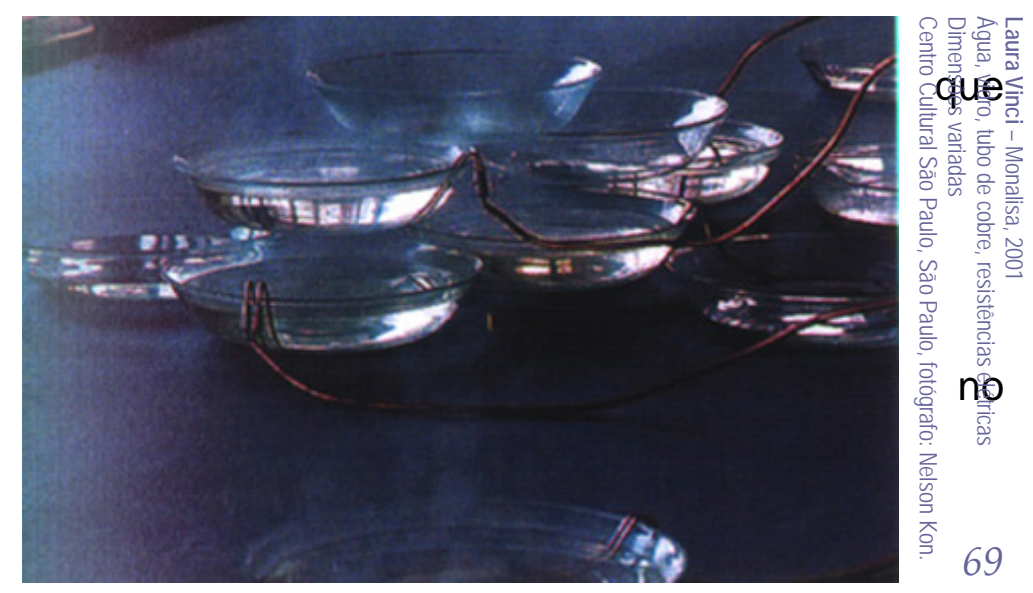


apresentado na Bienal de São Paulo; a fluidez no trabalho "Címbalos" apresentado na Galeria $10,20 \times 3,60$ ou o congelamento no trabalho apresentado na Galeria Nara Roesler.

$\mathrm{Na}$ instalação "Mona Lisa", Laura dispôs sobre o chão uma grande quantidade de bacias de vidro com água aquecida por resistências elétricas de cobre. A água sofre o processo de ebulição, criando uma certa névoa no espaço. A transparência do vapor, da água e do vidro das bacias une visualmente os três elementos, como se o vidro fosse lentamente se tornando imaterial, liquefazendo-se e evaporando pelo espaço.

A fluidez destaca-se no trabalho "Címbalos", em que a água corre por pequenos canos de vidro e mangueiras plásticas, formando desenhos espaciais entre peças circulares de metal prateado, que servem também para conter algumas gotas que escapam do circuito. A circulação lenta permite-nos ver pequenas bolhas de ar que estão presas no meio líquido e provoca um fluxo luminoso sutil que reverbera refletindo-se delicadamente no metal espelhado.

Já na galeria Nara Roesler, Laura Vinci constrói uma grande estrutura em canos resfriados ao redor dos quais a umidade presente no ambiente é congelada. Nestes canos também estão presas letras resfriadas, com as quais a artista escreve um texto poético sobre o espaço. Além de ficarem recobertas pelo gelo branco produzido pela umidade do espaço em que se inserem, estas estruturas congeladas deixam gotas de água pingar ocasionalmente sobre o chão, convertendo assim o ar em matéria líqüida. O fluxo constante existente entre os diferentes estados da matéria no trabalho de Laura atua de maneira a explicitar o espaço vazio, corroendoo e sendo corroído por ele.

Ao invés dos estados da matéria, o que interessa à artista brasileira Betty Leirner é principalmente o fenômeno da transparência dos líquidos. Em uma exposição apresentada na Alemanha, a artista apresentou uma série de recipientes de vidro em diversos formatos contendo diferentes soluções químicas transparentes, incluindo a própria água. Embora os líquidos incolores se equivalessem visualmente, ao observador era possível identificar sua composição através de etiquetas que descreviam o conteúdo dos frascos. A artista propõe uma discussão entre a aparência e o conteúdo, questionando o primado da visão, explorando a ambigüidade das imagens. $O$ interesse de Betty Leirner pela água e pela transparência não se restringe a este trabalho. Um de seus livros-objeto é composto por diversas palavras tenuamente impressas sobre folhas plásticas transparentes. As palavras se misturam umas às outras, criando uma interessante poesia verbovisual. Já no vídeo "Lovers", realizado no Japão, a artista filma duas garças quase 
imóveis que se equilibram sobre uma intensa corrente fluvial. A rápida fluidez das águas que passam sobre os pés dos animais contrasta com sua postura altiva e ereta, criando uma metáfora bastante poética sobre o fluir da vida e a luta pela sobrevivência.

Geórgia Kyriakakis também vem realizando trabalhos com líquidos, que embora nem sempre sejam água, remetem a características semelhantes a este material. Em uma exposição realizada na Galeria Raquel Arnaud, Geórgia suspendeu tubos de vidro com óleo de maneira que todos estivessem alinhados pela linha divisória criada pela superfície dos líquidos. Em algumas esculturas de chão, Geórgia encaixa peças de vidro soprado fechada com líquidos sobre bases de gesso. O líquido ocupa exatamente o mesmo nível da placa de gesso que envolve o recipiente de vidro. Geórgia parece interessada na idéia de horizonte, no equilíbrio horizontal a que se submetem os líquidos e as outras matérias que ela maneja. Em uma videoinstalação mostrada em 2006 no Centro Universitário Maria Antônia, a artista apresenta diversas imagens de um líquido verde em movimento que lentamente preenche recipientes de vidro em diferentes formatos. Ao serem preenchidos com o líquido, os vidros começam a se movimentar, alterando seu peso e buscando uma nova organização espacial condicionada pela fluidez e pela gravidade. Embora o trabalho não apresente claras referências narrativas e se atenha a exibição dos processos, é possível interpretá-lo como uma metáfora para a criação da terra, na qual massas se movimentam até encontrarem um equilíbrio estável no meio líquido.

A fluidez ocorre também em um trabalho de Rivane Neuenschwander. Aqui a artista pendura baldes com furos por onde pinga água lentamente, até preencher outros baldes que estão colocados sobre o chão. Após o seu preenchimento a água é novamente despejada nos baldes superiores e volta a pingar ciclicamente.

Em todos estes trabalhos, os processos temporais e espaciais são parte fundamental da significação da obra. Embora possam ser mais ou menos metafóricos, variando conforme o artista e a obra, todos eles apóiam-se nas manifestações fenomenológicas da água e extraem de suas características materiais a essência de sua poética. 


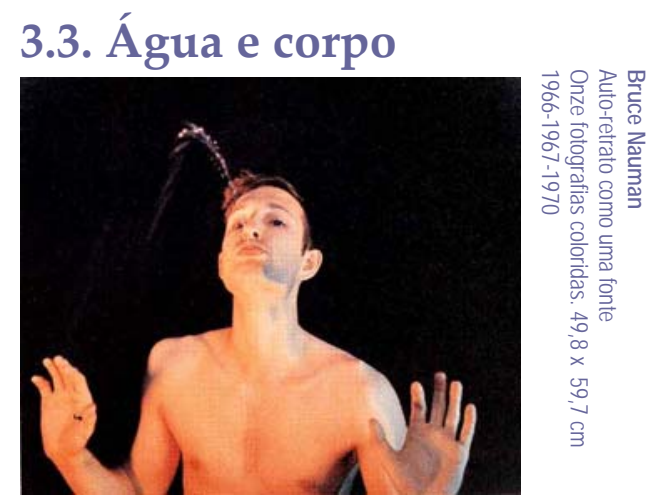

Na produção de arte contemporânea é possível encontrar inúmeros exemplos em que as relações entre água e corpo são fundamentais. As conexões entre água, sexualidade, vida e morte parecem ser uma constante nestes trabalhos.

Ora a água é utilizada como material para performances, ora ela compõe instalações interativas que estimulam os sentidos, ora surge misturada a pigmentos vermelhos em uma forte referência ao sangue.

A maior parte destes trabalhos aparece a partir da década de 60, quando a tentativa de aproximação da arte e da vida começa a se impor na história da arte e o trabalho artístico passa a assumir formas diversas daquelas oferecidas pelos meios e gêneros artísticos tradicionais.

Uma das imagens mais conhecidas deste período é a fotografia "O artista como Fonte" de Bruce Naumann. Nela o artista aparece sem camisa cuspindo um jato de água como se ele próprio fosse um chafariz. O ato banal e irônico ganha o status de arte e dialoga com a história da arte. Ao invés de produzir propriamente uma obra com materiais que são formalizados, Naumann utiliza seu próprio corpo como material artístico e comenta ironicamente o estatuto da obra de arte. A fonte representada pelo artista possui diversas possibilidades de interpretação. Das tradicionais fontes decorativas da arquitetura aristocrática o artista empresta a qualidade "artística", mesmo que em seguida a negue ironicamente. A água teria aqui um papel de divertimento e prazer. Alguns comentadores vêem também uma relação entre esta obra e o trabalho "Fonte" de Marcel Duchamp. Enquanto o urinol de Marcel Duchamp seria um receptáculo para receber os líquidos, na obra de Bruce Nauman o líquido jorra da boca do artista em direção ao espectador. Neste caso a conotação da água seria principalmente sexual. Uma terceira possibilidade de interpretação seria uma leitura mais metafórica do trabalho, que consideraria o artista como uma fonte de idéias. A água como elemento da criação poderia ser aqui percebida. Esta terceira interpretação ganha importância quando se conhece a obra "O artista é uma maravilhosa fonte luminosa", do mesmo autor. Esta obra consiste de um vídeo no qual a frase-título do trabalho pisca incessantemente no monitor, ao mesmo tempo que é repetida em voz alta sem parar. O trabalho apresenta-se como um paradoxo irônico, já que de um lado sua mensagem reforça a idéia do artista 
como gênio criador, e de outro lado o vídeo não apresenta qualquer virtuosismo ou sedução estética, apenas irrita pela repetição. A postura ambígua destes dois trabalhos põe o observador em xeque, colocando-o em dúvida entre aceitar a mensagem proposta pelo artista ou desconfiar de seu cinismo.

Enquanto o trabalho de Naumann se estrutura através de um certo distanciamento irônico do artista baseado em uma postura marcadamente mental, o mesmo não acontece no trabalho dos artistas neoconcretos brasileiros, cujo interesse volta-se mais para a experiência sensorial interativa do observador.

Lygia Clark e Hélio Oiticica usaram a água esporadicamente em sua obra. No final de sua carreira, Lygia Clark, que não se considerava mais artista e sim propositora ou terapeuta, desenvolveu seus "Objetos Relacionais". Estes objetos consistiam de sacos plásticos com água, ar, areia, bolinhas de isopor e outros materiais que eram aplicados sobre o corpo das pessoas de forma a provocar sensações corporais que libertassem determinados conteúdos inconscientes impossíveis de ser verbalizados. A aplicação destes objetos teria uma caráter terapêutico e a água, assim como os outros materiais, agiria sobre a sexualidade e o inconsciente.

A experiência sensorial também está presente no trabalho de Hélio Oiticica porém o artista não objetiva efeitos terapêuticos, mas a busca de novas formas de sensibilização da arte além da exclusividade da visão. Em seus "Penetráveis" o espectador deve pisar na água, em pedras e em areia, vivenciando corporalmente o trabalho.

Enquanto no trabalho de Lygia Clark e Hélio Oiticica a relação entre corpo e água se dá pela exterioridade da pele, em outros artistas os líquidos servem como metáfora para a circulação dos orgãos internos. Nestes artistas, a água tingida de vermelho faz uma forte referência simbólica ao sangue.

A artista Rebeca Horn também realizou uma série de trabalhos com a presença de líquidos. Embora em alguns trabalhos, Rebecca também tenha utilizado a água cristalina, a artista utiliza com mais frequência a água tinjida de vermelho. Em seu trabalho, os líquidos estão quase sempre em movimento ocasionado pela presença de mecanismos que os fazem circular. Com uma forte relação com o corpo e a performance, seus trabalhos muitas vezes fazem uma alusão à circulação sanguínea e às operações vitais. 


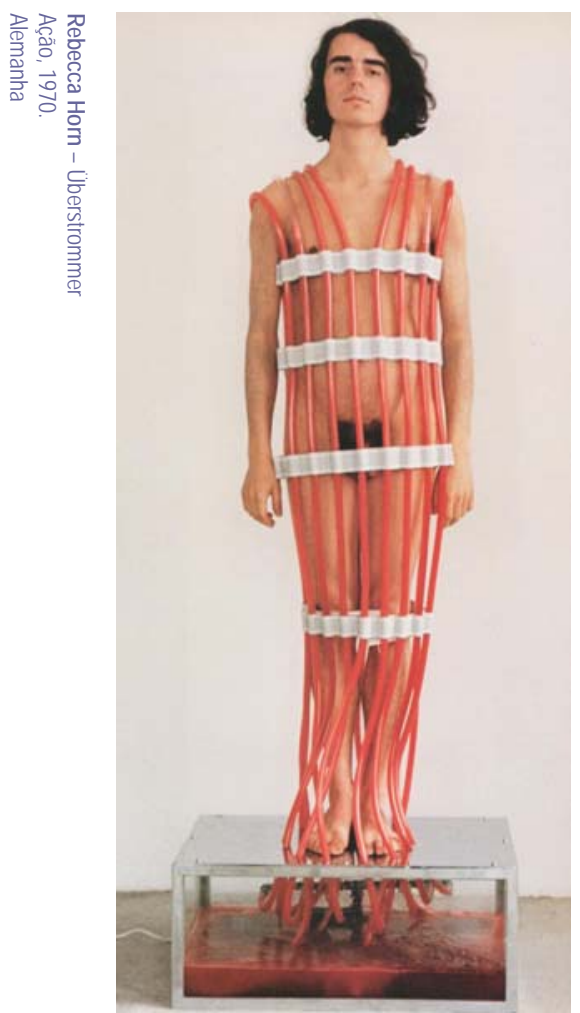

O trabalho Überstromer, por exemplo é constituído de uma série de mangueiras de plástico transparente com líquido vermelho em constante circulação. As mangueiras são presas a uma caixa de vidro e funcionam como uma espécie de roupa que é vestida por um homem nu em uma atitude performática. A circulação do líquido vermelho sobre o corpo nu do homem evidenciam os processos de circulação e a fragilidade da vida, que geralmente ocorre internamente em nossas veias.

No trabalho High Moon de Rebecca Horn, dois rifles Winchester são voltados um contra o outro e atiram-se mutuamente esguichadas de líquido vermelho. Os recipientes que servem como reservatório do líquido vermelho estão colocados acima dos rifles e tem o formato de dois seios feitos em vidro transparente. No chão há uma longa canaleta que passa bem abaixo dos rifles, cheia do líquido vermelho derramado. Unindo elementos femininos e masculinos este trabalho sugere uma reflexão sobre a violência e as relações conflitantes entre os homens. Através de trabalhos viscerais e irrequietos, Horn procura desestabilizar o espectador, tirando-o de uma atitude contemplativa, em um trabalho que parece fluir nervosamente.

Stela Barbieri também realiza uma série de trabalhos em que utiliza líquidos vermelhos. Em sua produção inicial, Stela desenvolve várias experiências com sacos plásticos com líquidos vermelhos, que são arranjados em composições orgânicas. Passando a trabalhar com o látex, Stela constrói peles e membranas que preenche ora com terra, ora com líquidos e outros materiais, numa clara alusão aos orgãos corporais. Em algumas peças de vidro soprado, que lembram conchas e em outras que parecem pimentões, Stela introduz líquidos vermelhos e amarelos que ao mesmo tempo se impõem pela cor e pela transparência. A extrema organicidade de seu trabalho remete-nos a imaginar os fluxos sangüíneos e corporais vitais. No trabalho "Banquete", apresentado 2003 no Museu de Arte de
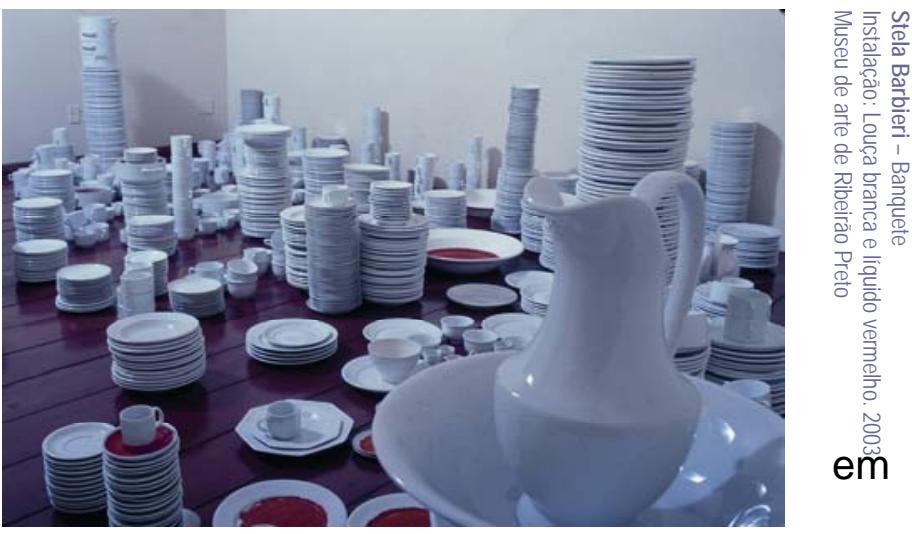
Ribeirão Preto, Stela constrói uma instalação com centenas de peças de louça branca empilhada, sobre as quais derrama um líquido vermelho. $\mathrm{O}$ contraste entre a 
imponência aristocrática da louça branca e o líquido de cor estridente que a macula constitui o cerne poético do trabalho. Os líquidos no trabalho de Stela parecem conter uma vida irrequieta, inconformados com os recipientes que insistem em contê-los.

Os líquidos vermelhos surgem também em trabalhos de Lígia Pape e Cildo Meirelles. A associação do vermelho com o sangue novamente se faz presente. Lígia Pape realizou uma instalação em que uma cachoeira de água vermelha flui incessantemente, fazendo uma alusão à violência e ao extermínio dos indígenas no Brasil. Na instalação "Desvio para o Vermelho", de Cildo Meirelles o líquido vermelho jorra em uma possível alusão à ditadura militar. Sobre o trabalho deste artista tecerei maiores comentários no item seguinte.

Não é apenas como referência ao prazer sensorial ou à circulação sangüínea que a relação água e corpo aparece na arte contemporânea. Também os líquidos desprezados como a urina e o suor são representados pela água em alguns artistas. O trabalho do artista espanhol Iñigo Manglano-Ovalle ocupa-se destas questões. Em 1998, o artista apresentou uma instalação na Bienal de São Paulo na qual havia três bebedouros que poderiam ser utilizados pelo público. $O$ espectador, que bebia da água destes bebedouros, era informado da procedência da água apenas se lesse a etiqueta de identificação do trabalho. A água era obtida pela purificação química de líquidos corporais de diversas pessoas. Ao tomar conhecimento desta informação, o espectador sentia uma certa repugnância da água que acabara de beber. O contato com o corpo do outro dava-se por uma via bastante física, embora esta relação passasse à primeira vista como despercebida.

Em outro trabalho de Manglano-Ovalle a relação com o corpo do outro novamente se dá pela água. Nesta instalação o artista oferece ao público a oportunidade de entrar em uma terma d'água trajes de banho, recriando o espaço de um spa. O que o espectador não sabe, porém, é a água desta terma não é trocada, de forma que os fluidos corporais de todos os indivíduos permanecem ali retidos e misturados uns aos outros.

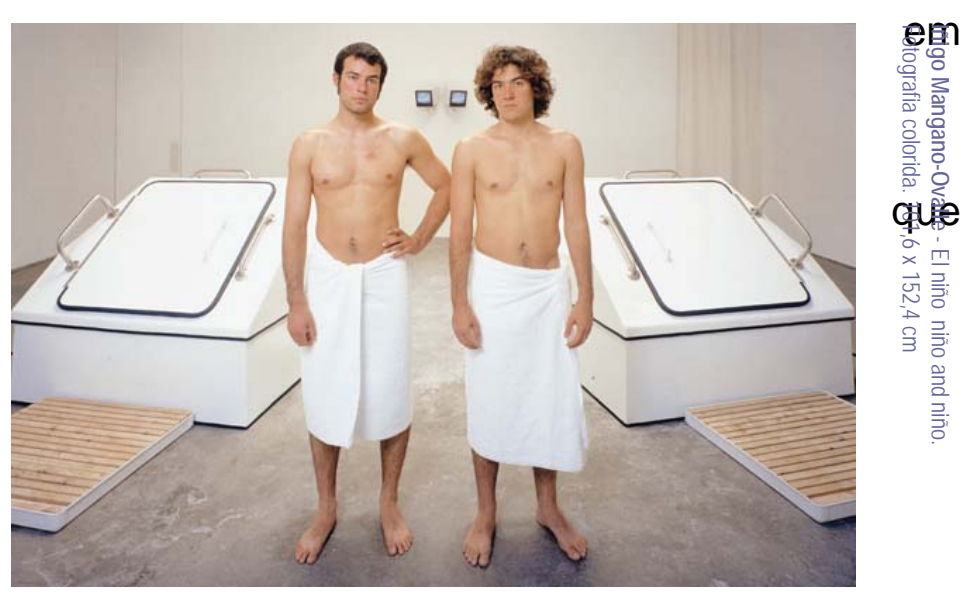


A mesma repugnância das obras de ManglanoOvalle é vivenciada pelo espectador das obras artista mexicana Teresa Margoles, porém de forma ainda mais dramática. Como funcionária instituto médico legal na cidade do México, Margoles tem acesso à água com que se lavam cadáveres, material que utiliza para a realização suas instalações. Em uma exposição na Alemanha, Margolles ocupa todo o museu com trabalhos relacionados à água. Na primeira sala espectador encontra um espaço totalmente vazio vê apenas belas bolhas de sabão produzidas por uma máquina. As bolhas sobrevoam levemente o espaço, às vezes estourando sobre o corpo dos passantes. Apenas ao final o visitante é informado que aquelas bolhas foram produzidas com a água com que se lavaram cadáveres. Em outro ambiente o ar é tomado pelo vapor produzido com a mesma água. O visitante pode
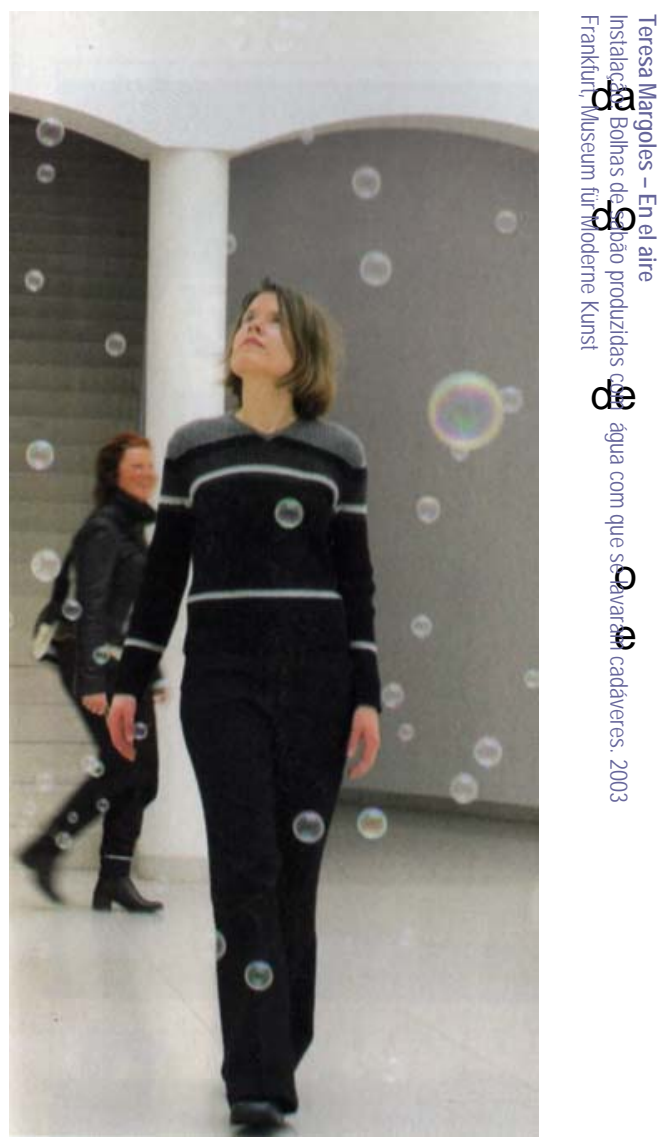
também sentar-se inadvertidamente sobre bancos de cimento em cuja confecção a água dos cadáveres foi misturada. A exposição também inclui um vídeo no qual se vê a lavagem dos corpos realizadas no instituto médico legal.

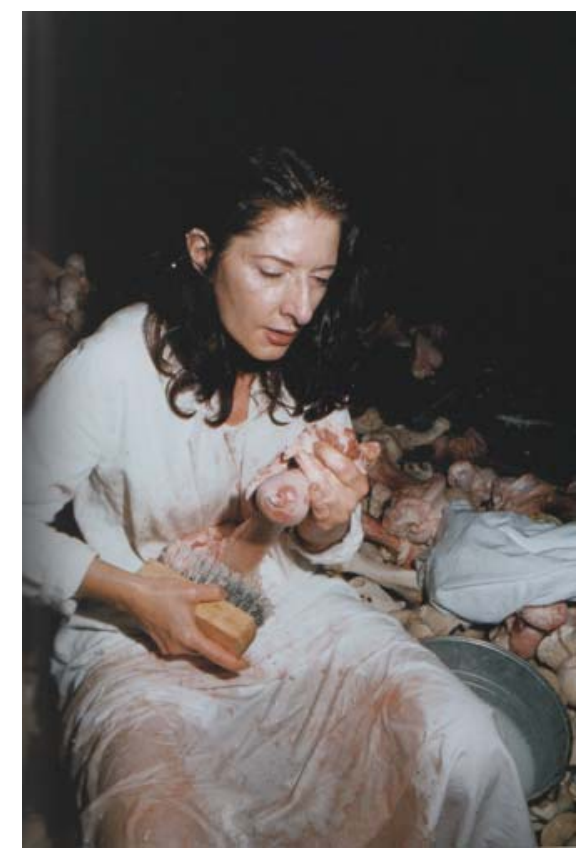

Se para Teresa Margoles a água serve para impregnar nosso corpo de morte, em uma performance de Marina Abramovic a água procura eliminar as dores fúnebres. Na performance "Balcan Baroque", apresentada na Bienal de Veneza, Abramovic lavou centenas de ossos com água, escova e sabão durante três dias seguidos. A obra fazia uma referência aos sangrentos conflitos políticos ocorridos recentemente na lugoslávia, terra de origem da artista. Com esta ação a artista recorre à tradição de purificação da água ao mesmo tempo que vivencia com seu próprio corpo o enfrentamento da morte.

A mesma estratégia de lavagem é utilizada pela artista brasileira Síssi Fonseca, porém em um contexto totalmente diferente. Desde 2003 a artista vem realizando uma série de lavagens em diferentes locais, nas quais utiliza seu próprio corpo como 
se fosse um pano de chão para lavar os espaços expositivos. Por meio de uma aprofundada pesquisa gestual a artista interage com objetos, com o público e com a arquitetura dos locais, utilizando vários baldes com água. Ao esfregar-se intensamente no chão e nas paredes, Síssi Fonseca limpa as sujeiras reais e metafóricas de galerias, centros culturais e outras instituições artísticas. Suas ações fazem alusões poéticas ao tradicional trabalho cotidiano feminino e ao trabalho de faxineiros e empregadas domésticas - todos estes trabalhos desvalorizados pela sociedade.

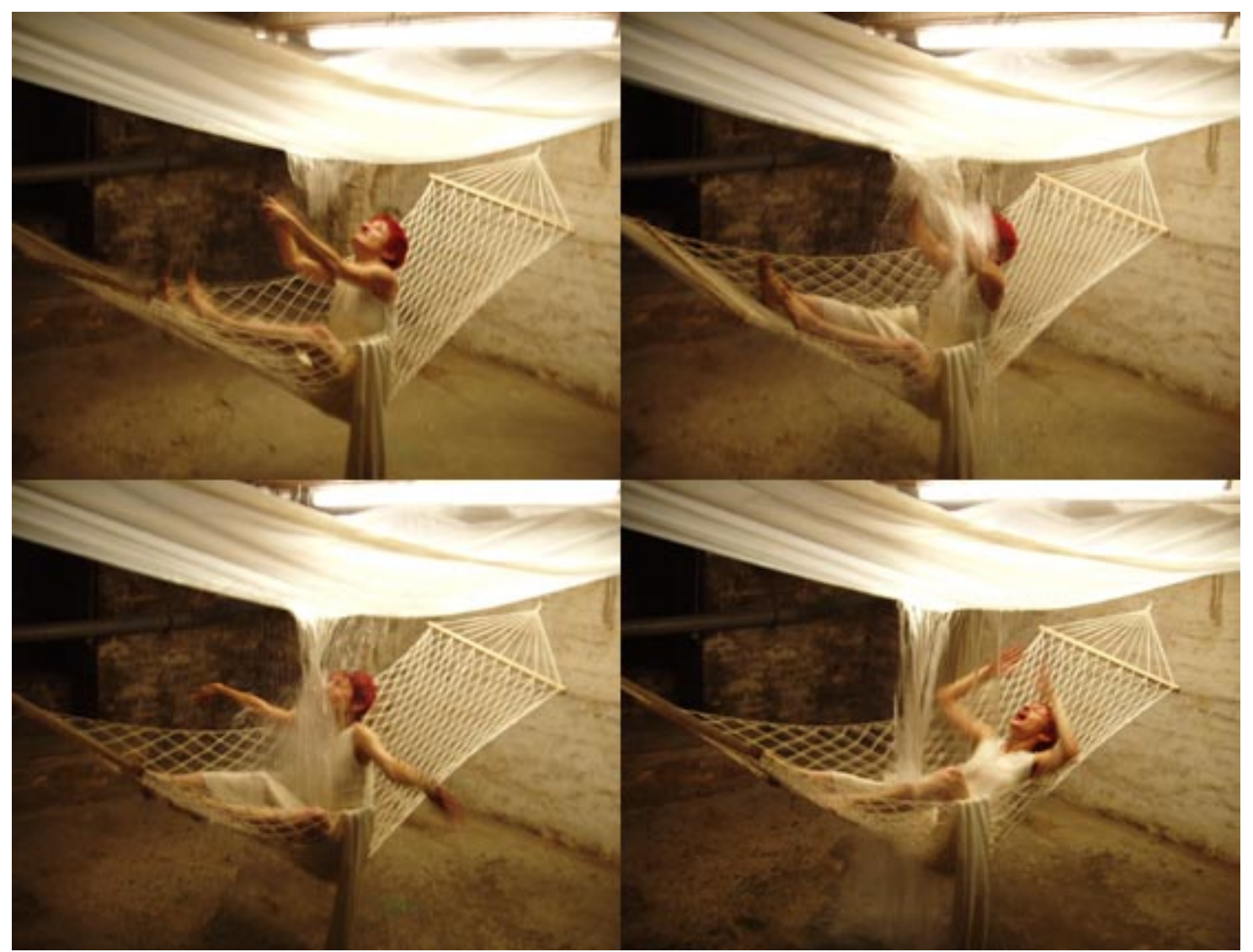

A performance "Ar e Chão" apresentada por Síssi Fonseca em Berlim em 2004, embora também utilizasse água, englobava outras questões. A performance realizava-se em duas etapas. Na primeira parte a artista cai repetidamente sobre o chão da galeria, tentando sempre se levantar novamente. Após esta série de quedas, a artista desce para o porão da galeria, onde deita-se em uma rede, sobre a qual está colocada uma grande folha de plástico transparente com água. Após permanecer imóvel na rede por alguns minutos, a artista corta repentinamente o plástico, fazendo com que a água despenque sobre ela. A dificuldade de se manter em pé, as relações entre o alto e o baixo, entre a elevação e a queda, entre o terreno e o divino e a impossibilidade de se conter a fluidez constituem o tema desta performance.

No trabalho do artista chinês Zhang Huan, o corpo é o veículo utilizado para a discussão de questões políticas e culturais. Ao invés da performance ao vivo, Huan 
prefere a sua apresentação em fotografia. No trabalho "To Raise the Water Level in a Fishpond" o artista convida uma grande quantidade de trabalhadores temporários para entrarem em um lago até que o nível da água se eleve. Incluindo estes trabalhadores que vêm de diferentes cidades do interior da China para a capital, em busca de trabalho e vida melhor, Zhang Huan comenta as mudanças sociais em seu país. O ato de elevar o nível da água do lago é uma ação que, em si, não tem nenhuma utilidade prática, mas que pelo menos temporariamente representa um trabalho para os desempregados e rejeitados da sociedade. A reunião do grupo de homens no interior do lago confere a cada indivíduo uma sensação de pertencimento ao mesmo tempo que os exibe frágeis e isolados. A água aqui envolve a todos, igualando-os e colocando-os em contato com a natureza.O contraste entre o corpo dos homens e a paisagem natural cerceada pela cidade confere uma beleza poética a cena.

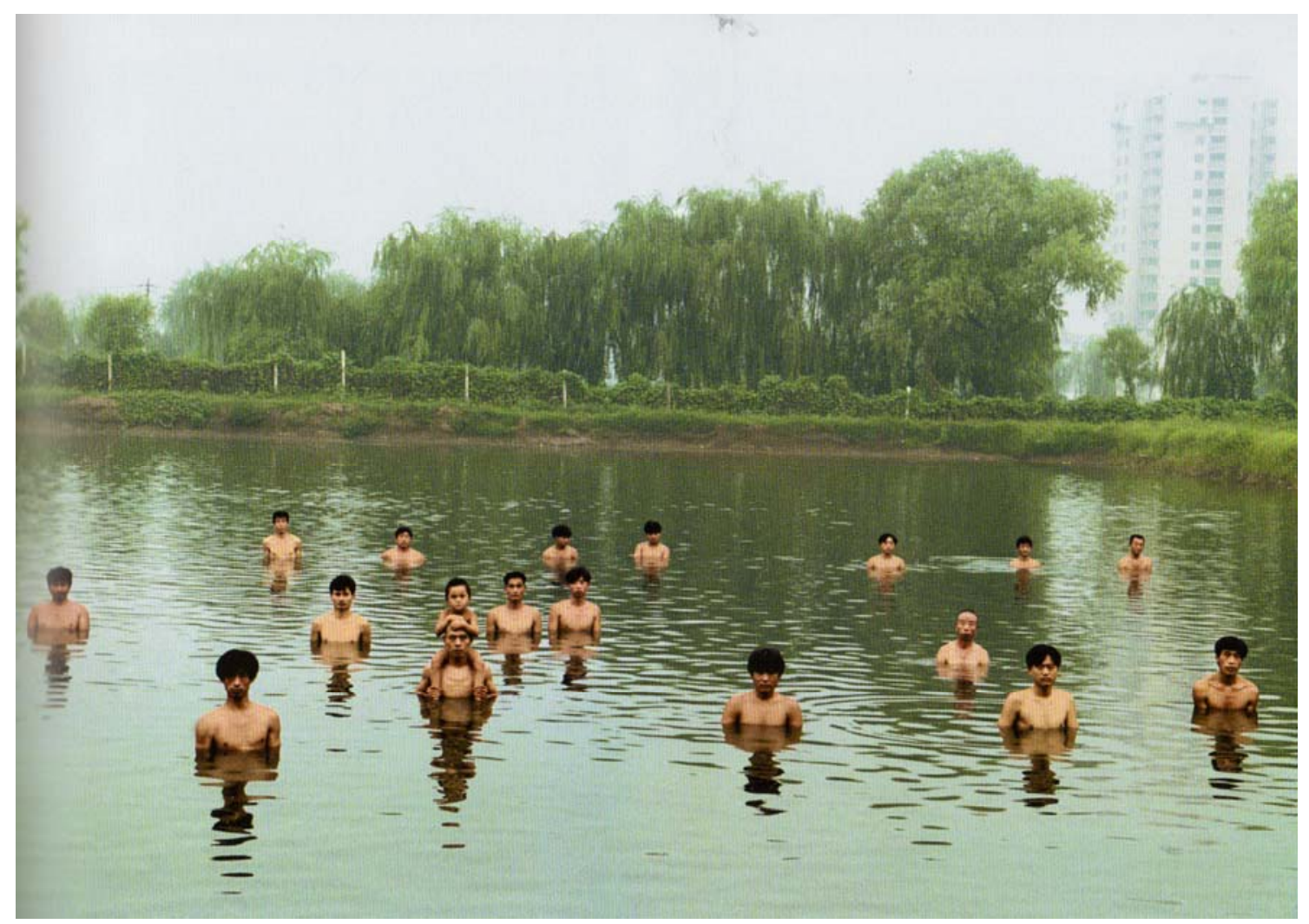




\section{4. Água, política, memória e espaço público}
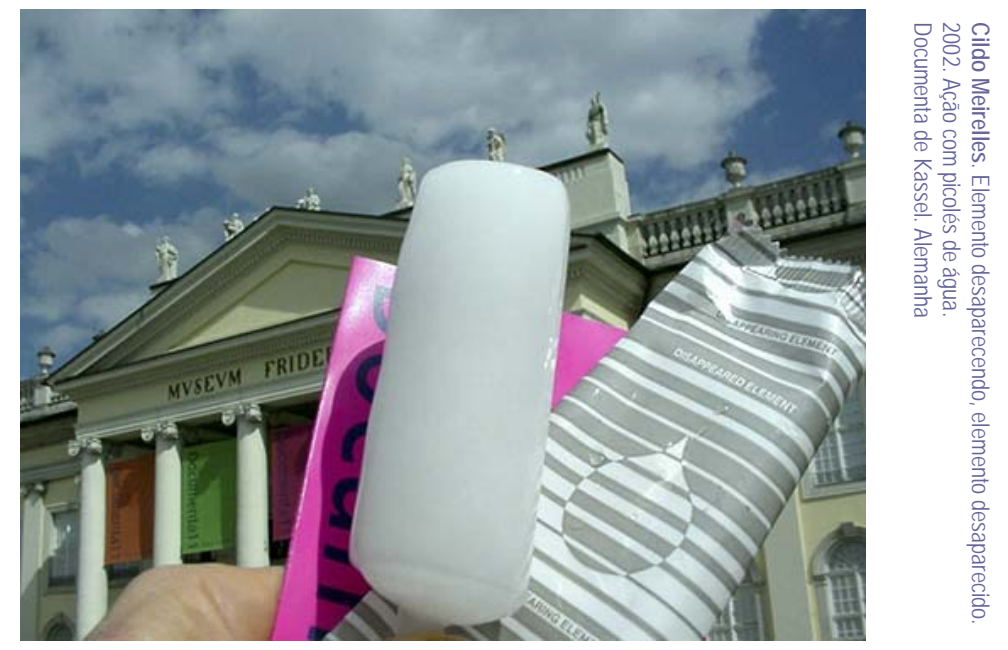

É possível encontrar entre os trabalhos realizados com água e outros líquidos, alguns que discutem aspectos históricos e sociais. Embora determinados artistas tratem de questões relativas à própria água, no que diz respeito a aspectos ecológicos, outros utilizam-se dos líquidos em aproximações mais metafóricas, em que a fluidez é sinônimo para a passagem do tempo e as transformações.

Cildo Meirelles realizou diversos trabalhos cujo teor político é bastante presente. $\mathrm{Na}$ instalação "Desvio para o Vermelho", por exemplo, após passar por uma sala de visitas onde todas as coisas eram vermelhas, o espectador é conduzido a um corredor escuro, onde finalmente encontra uma pia e uma torneira de onde jorra uma água vermelha intermitentemente. Realizado na década de 60, o trabalho pode ser visto como uma metáfora da violência da ditadura militar.O "sangue" que jorra da torneira contamina toda o ambiente doméstico, tornando-o um espaço inabitável. Aqui não se trata propriamente de um uso simbólico de uma matéria já carregada de sentido, mas de sua representação visual através da referência ao sangue.

Em um trabalho recente apresentado na Bienal de Veneza, Cildo Meirelles utiliza novamente a água, porém agora congelada em forma de sorvete. Em uma ação performática, Cildo instala uma série de carrinhos de sorvete de água na frente do prédio de exposições e os picolés de água são distribuídos aos visitantes. A falta de sabor do picolé e sua fugacidade parecem nos alertar para a precariedade da situação brasileira e para o vazio do ambiente artístico contemporâneo. A água aqui é símbolo irônico de si mesma, incolor, insípida, e inodora. O trabalho utiliza-se da lógica do comércio, "barateando" a arte, tornando-a acessível a todos, ao mesmo tempo em que se esquiva de uma interpretação fácil baseada apenas em apelos estéticos. O trabalho pode ser também compreendido como uma crítica a distribuição desigual da água potável no globo terrestre e as relações comerciais 
envolvidas em sua produção. Mais do que isto, porém, o trabalho situa-se em uma zona mais ambígua, que envolve a discussão das questões de valor não apenas da água, mas da arte e de outros produtos comerciais.

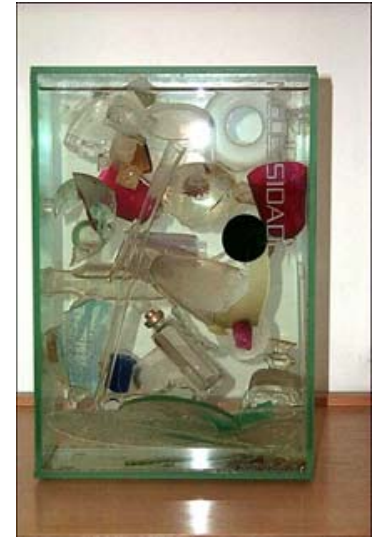

Embora de maneira bastante diferente, a artista Nina Moraes interessa-se também pelos produtos da sociedade de consumo. Em seu trabalho, os líquidos aparecem envolvendo objetos transparentes capturados da vida diária, compondo compotas de detritos da sociedade industrial arranjados ironicamente em uma visualidade sedutora. A recorrência do plástico e dos objetos quebrados em seu trabalho, faz-nos pensar na obsolescência planejada de nossa sociedade baseada em matéria artificial. A água e outros líquidos no trabalho de Nina têm mais a função de aglutinar os objetos do que de purificá-los. A aparência dos líquidos em suas compotas varia entre as referências ao líquido placentário ou ao formol conservante. Pedaços extraídos da vida são coletados e armazenados em vidros que assinalam sua morte. A artista chama estas obras de compotas, numa clara referência ao comestível e ao passado. Engolimos não apenas alimentos, mas todos os produtos descartáveis que a sociedade de consumo nos impinge. As compotas são quitutes preparados por nossas avós; nas famílias mais abastadas, exibir em belos vidros e cristais uma cuidadosa coleção de compotas feitas artesanalmente era sinônimo de status e bons modos. Nina Moraes recupera esta lógica burguesa para colocar-nos frente a frente com o consumismo contemporâneo.

O trabalho de Nina Moraes relaciona-se principalmente com a memória individual ligada ao passado familiar. Já a obra da dupla de artistas alemães Horst Hoheisel e Andreas Knitz refere-se principalmente à memória pública. Em Kassel, no local onde havia uma antiga fonte em homenagem aos judeus, destruída pelos nazistas durante a segunda guerra, os artistas construíram uma nova fonte em que a água ao invés de jorrar para cima como no monumento original, escorre para o centro da terra. O formato da fonte original foi reproduzido em um molde em negativo e está colocado de ponta-cabeça abaixo do nível do solo.

Através desta obra, Hoheisel e Knitz discutem o apagamento da história simbolizado pela queda d'água que se projeta para o interior da terra, sem uma expressão eufórica, mas ao contrário, num fluxo regressivo. A fluidez da água é associada ao fluxo do tempo. Ao retornar para o interior da terra, a água parece querer funcionar como uma limpeza e purificação das injustiças da história. O trabalho é concebido como um anti-monumento, que ao invés de celebrar heroicamente um fato, demarcando pela imponência o seu entorno, prefere ocultar-se abaixo da terra funcionando como um espaço para a reflexão política. 


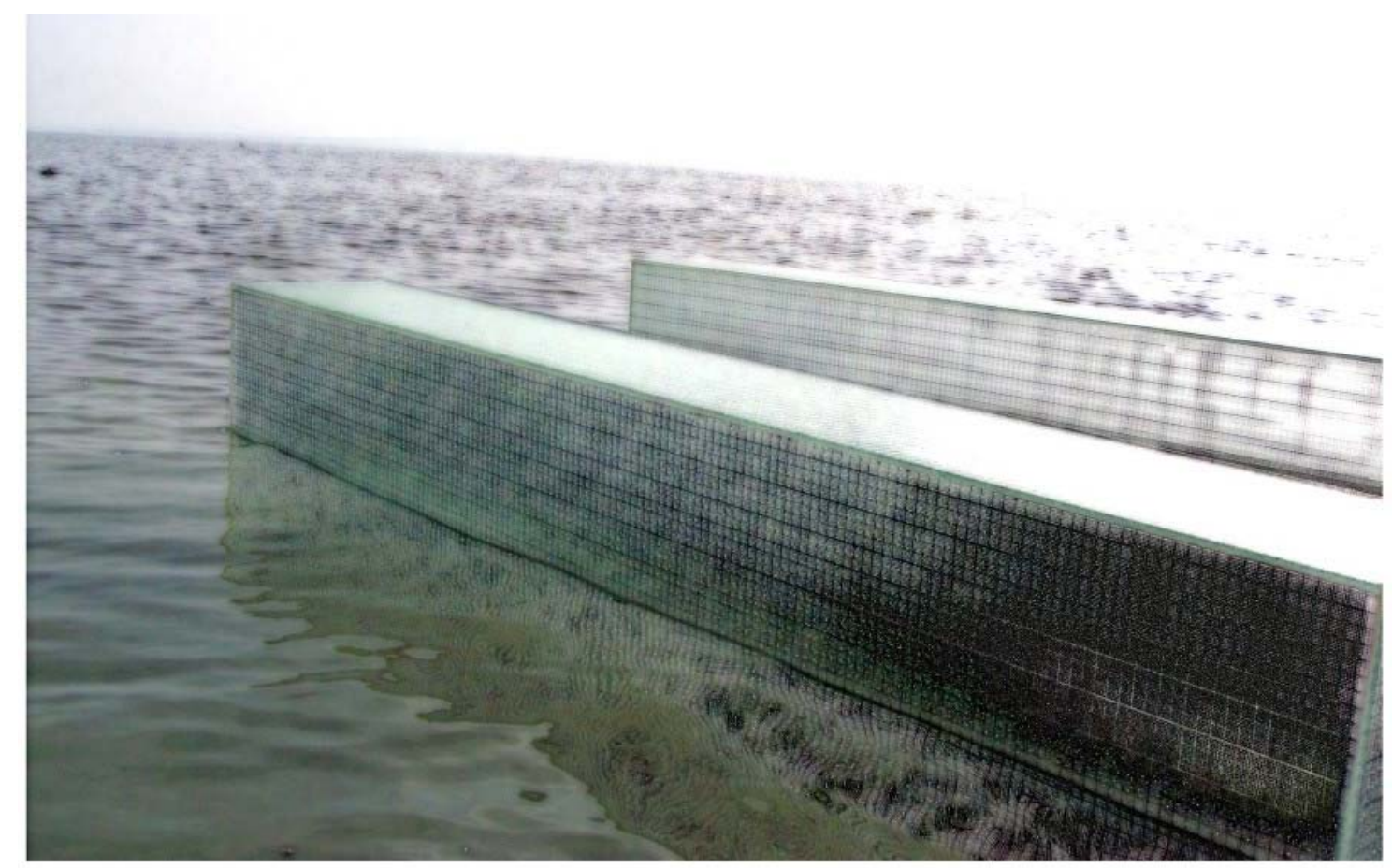

O projeto para o memorial a ser construído para o World Trade Center utiliza a mesma lógica do anti-monumento. Neste projeto, Hoheisel e Knitz propõem a construção de prédios do mesmo tamanho das torres originais, porém ao invés de erigí-las verticalmente, os artistas pretendem colocá-las na posição horizontal, flutuando sobre as águas que envolvem Manhattan. A proposta inclui também a utilização prática dos prédios, como centro cultural, museu histórico e espaço para eventos. A referência à queda das torres está presente no trabalho, cuja horizontalidade remete à idéia de morte. A imponência das torres originais é substituída pela flutuação instável e leve sobre as águas. O projeto não foi aceito pela comissão de avaliação americana, que optou pela construção de um monumento ainda mais alto do que as torres gêmeas. A idéia da queda, presente na proposta de Hoheisel e Knitz poderia ser mal aceita por alguns setores da sociedade americana. Mesmo assim, os artistas exibem seu projeto como obra, cuja impossibilidade de realização apenas demonstra sua potência política questionadora.

A discussão política da memória social é bastante freqüente na produção contemporânea alemã. Em obras dos coletivos Empfangshalle e Raumlabor-Berlin

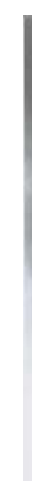
observa-se esta tendência.

Empfangshalle é uma dupla composta pelos artistas Corbinian Böhm e Michael Gruber oriundos de Munique. Em 2002 os artistas apresentaram na cidade de Gelsenkirchen o trabalho Gelsenlos. A igreja St. Urbanus de Gelsenkirchen 
teve sua torre totalmente destruída durante a segunda guerra e permanceu assim até hoje. O trabalho Gelsenlos trata da reconstrução efêmera desta torre a partir de jatos de água que jorram para o alto, reproduzindo a forma original da cúpula da igreja. Esta fonte no alto da torre porém só funciona esporadicamente. Para colocála em funcionamento é necessário comprar um bilhete de loteria vendido por um desempregado que foi contratado especificamente para este fim. Apenas os bilhetes premiados fazem jorrar água da fonte. Desta forma, os artistas chamam a atenção para o problema social do desemprego, além de introduzirem um aspecto lúdico no trabalho. Partindo de uma referência à história, os artistas colocam em questão as relações comerciais e sociais da sociedade atual. Enquanto a espiritualidade é simbolizada pela água que jorra da igreja em direção ao céu, a fugacidade e o materialismo terreno são experienciados através do caráter efêmero da obra e das relações de troca implícita em seu funcionamento.

Crítica social e memória também estão implícitas no projeto coletivo Die Fassadenrepublik, coordenado pelo Raumlabor-Berlin. Mais do que uma obra de arte isolada, Die Fassadenrepublik foi um evento de grandes proporções, que em 2004 ocupou todo o prédio-sede desativado do antigo governo socialista da exBerlim Oriental. O prédio, que esteve abandonado por vários anos após a reunificação das Alemanhas, foi retomado por artistas plásticos, arquitetos, atores, cenógrafos e outros artistas com o objetivo de realizar uma intervenção lúdica que discutisse criticamente seu passado político. Todo o piso principal do edifício foi impermeabilizado e enchido com cerca de meio metro de água, de forma a criar um enorme lago navegável no interior da arquitetura. Neste grande ambiente aquático, foram criadas ilhas que abrigavam representações de diversas partes de uma suposta cidade da antiga Alemanha Oriental. Ao chegar ao prédio, o espectador era colocado em botes infláveis puxados por funcionários que andavam dentro da água, levando os visitantes de uma ilha à outra. Esta espécie de pequena Veneza abrigava em suas ilhas a representação das mais disparatadas instituições da antiga Alemanha Oriental, desde repartições oficiais, onde se poderia carimbar passaportes até bordéis fictícios e restaurantes. A situação ganhava um tom cômico e absurdo graças a encenação caricata de atores que interagiam com o público. A crítica política à burocracia e à desorganização da antiga Alemanha oriental era bastante clara no deboche de suas instituições. O evento era uma mistura de arte crítica e parque de diversões, que privilegiava a interação e participação do público. A diversão porém não tinha o objetivo de alienação, mas sim de provocação do debate político. O evento também pretendia colocar em discussão a reutilização do prédio, que estava abandonado e prestes a ser demolido. 


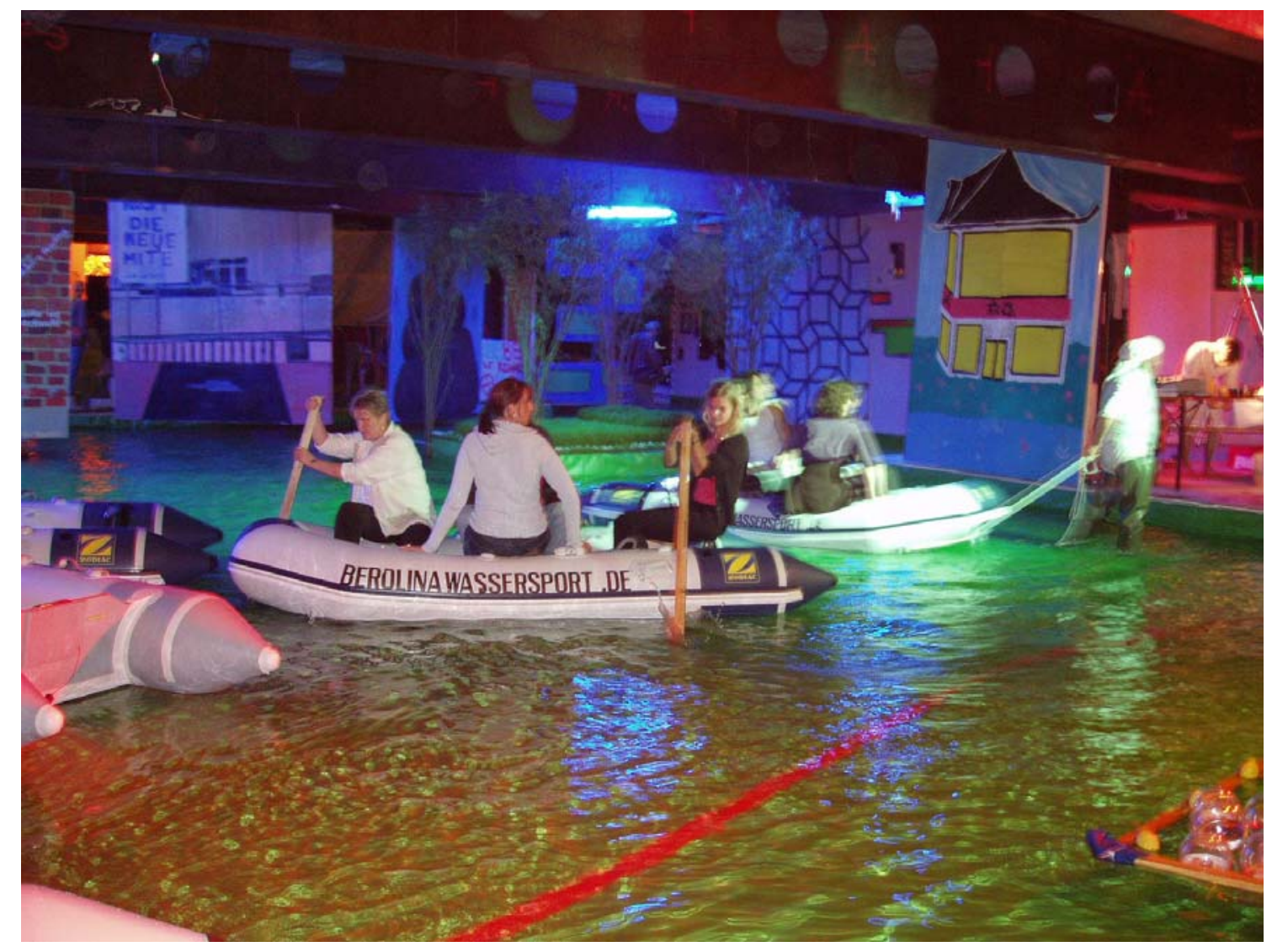

A presença da água neste trabalho foi fundamental por vários aspectos. Além de conferir um aspecto lúdico criando uma nova forma de circulação pelo interior do prédio, ela funcionou como um elemento do absurdo, que aumentava a confusão do deslocamento. $\mathrm{O}$ isolamento das ilhas pela água pode ser entendido como uma metáfora das dificuldades de comunicação entre as diversas instituições políticas da Alemanha Oriental. A fluidez parece assinalar a passagem do tempo e a impossibilidade de se conter as mudanças históricas.

Em outro projeto coletivo realizado Berlim em 2004, pela artista Susanne Lorenz em conjunto com grupo de arquitetos, a arte coloca-se só a serviço da discussão do passado, mas apresenta soluções práticas sobre as condições ambientais atuais. A artista criou uma piscina em tamanho natural que flutua nas águas do rio Spree, presa

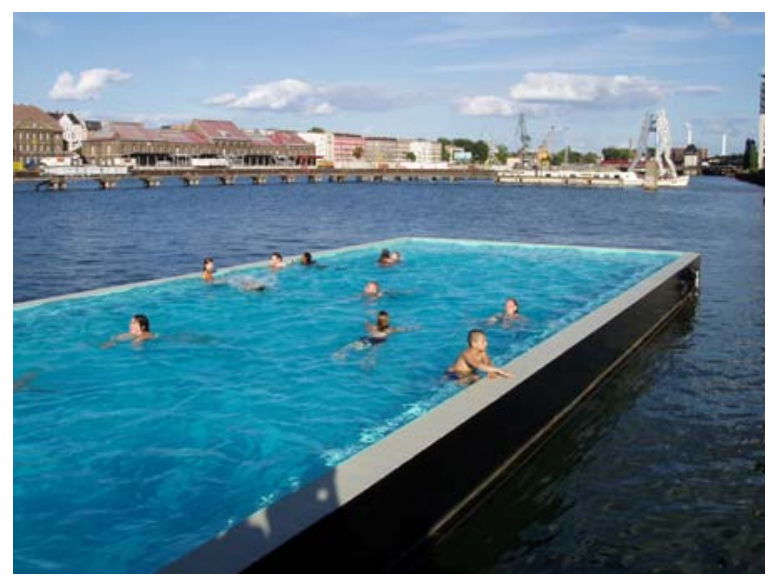

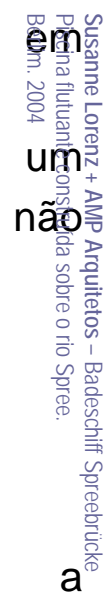
um deck de madeira onde se pode tomar sol. A piscina pode ser freqüentada normalmente pela população, que assim tem a possibilidade de se banhar em proximidade da natureza, embora os mergulhos no rio sejam proibidos devido à 
poluição. O tom crítico do trabalho encontra-se justamente aí. No passado era comum banhar-se no rio Spree, porém com o desenvolvimento da sociedade, isto se tornou impossível. Com a construção desta piscina, Susanne Lorenz repõe esta carência histórica ao mesmo tempo que oferece um ponto de encontro e diversão para os visitantes. Sua arte não se destina à contemplação, mas busca uma intervenção ativa sobre o meio social.

O artista dinamarquês Jeppe Hein também realiza intervenções no espaço público, porém seu enfoque é mais lúdico do que político. Hein recupera a idéia das fontes, criando obras interativas com água. O artistas constrói uma espécie de paredes de jatos de água, que podem surgir ou desaparecer através de um controle mecânico. O espectador pode entrar no espaço existente entre as paredes aquáticas quando elas se abaixam, porém pode ficar repentinamente preso entre elas, se a água voltar a jorrar. Este interessante labirinto de águas cria uma cumplicidade lúdica com o observador, que experiencia a obra visual e corporalmente.

As intervenções com água relacionadas ao espaço público não se restringem às obras arquitetônicas e de grandes dimensões. Alguns artistas como a alemã Kirsten

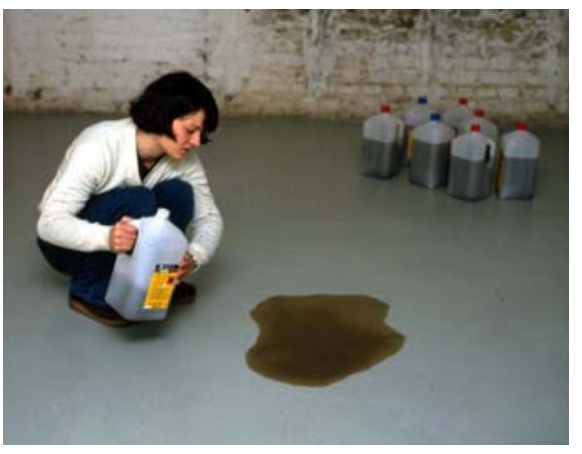
Pieroth ou as brasileiras Laura Belém e Néle Azevedo preferem ações mais singelas. Kirsten Pieroth coleta água de poças em ruas ou em áreas rurais, despejando-a em galerias. Desta forma a artista transfere a precariedade do espaço externo, para o interior asséptico dos espaços da arte. O elemento desprezado do cotidiano passa a ganhar o status de arte.

Já a artista Néle Azevedo contesta a idéia do monumento público ao realizar instalações com pequenas esculturas de gelo no espaço urbano. Em seu projeto "Monumento Mínimo", Néle interfere delicadamente sobre a cidade, trocando a rigidez e a imponência dos monumentos oficiais pela fluidez efêmera de seus pequenos homens de gelo, que derretem rapidamente frente aos olhos dos observadores.

Laura Belém aproveita as águas da paisagem urbana para realizar suas intervenções. Na Bienal de Veneza em 2005, Laura Belém instalou dois barcos voltados um para o outro sobre as águas de um dos canais da cidade. Os barcos iluminavam-se mutuamente através de faróis. A instalação ganhou o título "Os enamorados", referindo-se ao par formado pelas embarcações. A atmosfera romântica de Veneza contaminava até mesmo os objetos inanimados. 
É interessante notar que a utilização de rios, lagos e outras paisagens aquáticas para a realização de exposições e eventos artísticos tem se tornado tradição em algumas cidades européias. Em minha pesquisa pude encontrar vários exemplos de eventos deste tipo, como: o projeto Overtures: über Wasser, desenvolvido pela curadora Inge Lindemann nas cidades de Munique e Gelsenkirchen, o projeto Water Kunstwandelroute in de Amsterdamse Waterleidingduinen na Holanda e o projeto Kunst im Wasser, realizado anualmente na cidade de Lauf na Alemanha. Nem sempre todos os artistas convidados para estas exposições desenvolvem uma pesquisa específica sobre a água, ás vezes apenas adaptam suas criações ao ambiente aquático. Este tipo de exposição oferece, porém, uma interessante possibilidade de integração entre a natureza, o espaço público e a arte atraindo diversos tipos de público. A consciência social sobre o meio ambiente na sociedade européia e a relação menos distanciada entre a arte e as instituições políticas favorecem este tipo de iniciativa, o que no Brasil infelizmente ainda está longe de se tornar realidade.

\section{5. Água e vídeo}
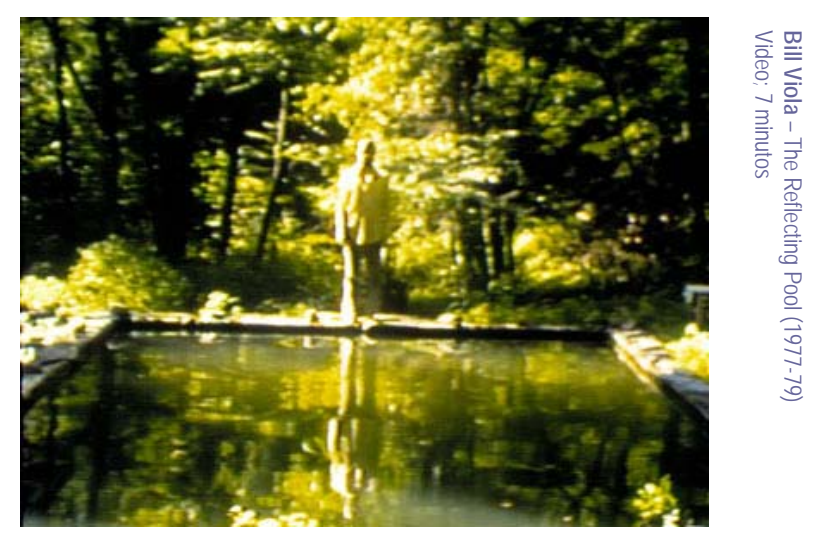

Na produção em videoarte desenvolvida principalmente a partir dos anos 80 pode-se encontrar interessantes trabalhos em que a água desempenha um papel fundamental. A ocorrência da água nestes vídeos varia de um artista para outro, indo desde a simples captura de imagens de paisagens aquáticas até a criação de performances para o meio líquido ou a montagem de instalações nas quais a água 
aparece não só como imagem eletrônica, mas também como material que dialoga com o vídeo. Alguns artistas, como Bill Viola e Fabrizio Plessi, vêem até relações metafóricas entre água e vídeo; para eles, a fluidez da água equipara-se ao fluxo de imagens do vídeo e as imagens refletidas na superfície aquática lembram as imagens luminosas em movimento do vídeo.

No trabalho "He weeps for you", Bill Viola instala em um lado da sala uma pequena câmera que enfoca uma gota d'água que cai lentamente sobre um grande pandeiro. A imagem captada pela câmera é projetada sobre uma grande tela em tamanho bastante ampliado. Ao cair sobre o pandeiro a gota d'água produz um som que é amplificado e ressoa como um grande estrondo.

Ao entrar na sala, no entanto, a imagem do observador é captada pela câmera através do pingo d'água. Como a água funciona como uma lente que distorce e inverte a imagem, o que vemos na tela é a imagem do observador de ponta cabeça, através da gota d'água que pinga lentamente.

Através desta instalação Bill Violla nos leva a pensar em questões como a passagem do tempo e a efemeridade das imagens e da vida, que pinga e se dissolve lentamente. Somos levados a refletir também sobre as relações entre o grande e o pequeno, entre o virtual e o real, entre o mundo físico e sua representação em imagem.

A água aparece no trabalho de Bill Viola também em outras obras.

$\mathrm{Na}$ instalação "The Sleepers", uma série de tonéis repletos de água até a boca exibem imagens de rostos de pessoas dormindo que parecem flutuar na superfície da água. Este efeito é obtido pois embaixo de cada tonel é instalado um monitor de vídeo de onde partem as imagens, que por reflexão e transparência parecem "subir" para a superfície aquática.

A interface criada com a associação da imagem eletrônica e do elemento líquido acrescenta conteúdos simbólicos e apelos visuais à instalação, que causa um estranhamento no observador pela junção de realidade e fantasia. Neste trabalho a questão do tempo também é enfocada, porém neste caso, o tempo de que se fala é o do sono, dos sonhos, da espera e da meditação.

Pode-se citar ainda na trajetória de Bill Viola outras obras em que a água aparece com destaque, como os trabalhos "The Crossing" e "The Reflecting Pool". Em "The Crossing" é apresentada uma tela que possui imagens diferentes projetadas na sua frente e em seu verso. De um lado pode-se ver a imagem de um homem que caminha entre chamas de fogo até ser consumido por elas. De outro lado vê-se a imagem de um homem que submerge completamente em um ambiente aquático. 
Através destes contrastes Bill Viola novamente nos leva a pensar nos processos de vida e morte e nas transformações sofridas pela matéria e pelo homem.

"The Reflecting Pool" trata-se de uma videoprojeção simples, porém de grande beleza poética. Em um bosque, um homem mergulha em uma piscina, porém ao saltar sua imagem fica congelada no ar. A imagem da água da piscina, no entanto, movimenta-se e ondula como se o homem estivesse dentro da água. A imagem congelada no ar começa lentamente a se dissolver e dá a impressão de pingar sobre a piscina. Ao desaparecer totalmente, a água para de se movimentar e o homem sai de dentro da água, caminhando em direção ao bosque.

Uma sensação de separação entre corpo e alma é transmitida pelo vídeo, já que a imagem situa-se novamente no limite do real e do imaginário. A conjugação do tempo congelado da imagem do homem prestes a cair no lago e do tempo real que é representado pela movimentação da água provoca uma dissonância cognitiva na apreensão da imagem.

De uma maneira geral, a questão das poéticas líqüidas é tratada de forma bastante lírica nos trabalhos de Bill Viola. Nem sempre o artista utiliza materiais reais em suas videoinstalações; em algumas o artista expõe apenas seus vídeos. Em grande parte delas, porém, o artista trata de questões existenciais através de uma pequisa de imagem altamente refinada.

Outro artista com trabalhos bastante interessantes na área de videoarte e que também trata com frequência das questões dos líquidos é o italiano Fabrizio Plessi. Nas videoinstalações de Plessi frequentemente são criadas situações em que o real e o virtual são colocados lado a lado. Na maior parte de seus trabalhos há uma presença importante de materiais e objetos físicos que são associados à imagem do vídeo. Diferentemente de Viola, que apenas esporadicamente utiliza objetos e matérias reais, privilegiando as imagens videográficas, o trabalho de Plessi constróise geralmente a partir do confronto entre a realidade e a ilusão, entre a imagem eletrônica e o mundo físico. Diferentemente de Violla, Plessi geralmente se utiliza de imagens bastante simples e repetitivas, que retratam quase que exclusivamente elementos água e fogo e raramente se articulam como seqüências narrativas.

No trabalho "Dover", por exemplo, uma série de televisões com imagens de água em movimento são colocadas no chão e circundadas por placas de mármore. Em um dos cantos da sala há um grande ventilador que sopra um forte vento que atinge também o observador. A impressão que se tem é que o vento real é responsável por agitar a água virtual da imagem transmitida pelas televisões. Não há verdadeiramente uma interação real, já que o vídeo e o ventilador não se 
apresentam como sistemas inteligentes e são pré-programados para simular uma interação. Tal simulação chega a colocar em dúvida o observador, que experimenta o trabalho de maneira lúdica, porém sem provocar alterações interativas em seu desenvolvimento.

Já no trabalho "Sevilla", Plessi pendura verticalmente na parede uma cruz formada por dezoito monitores de vídeo que exibem imagens de fogo flamejante. As imagens deste fogo eletrônico são refletidas em um espelho d'água colocado no chão da sala. Novamente as relações entre falso e verdadeiro são questionadas, porém neste trabalho são elementos ainda mais contrastantes que estão justapostos. Segundo o artista este trabalho faz uma referência a inquisição espanhola e reúne as simbologias da cruz cristã, do fogo e da água que ao mesmo tempo apresentamse como devoção e morte, purificação e aniquilamento.

No trabalho "Venezia" é afixada de ponta cabeça no teto uma mesa com um copo de vidro. Abaixo dela, sobre o chão, é colocado um balde que possui um monitor de vídeo em seu interior apresentando imagens de água, como se houvesse uma gota imaginária que caísse do copo colado à mesa do teto e movimentasse a água virtual presente no balde. Novamente neste trabalho, Plessi estabelece um conflito entre o verdadeiro e o falso, entre o material e o virtual. Também a sensação de interação entre o elemento físico e o imagético é sugerida, mas novamente trata-se apenas de uma simulação. No caso do trabalho de Plessi, o fato de não haver uma interatividade real não é problema, mas parte constituinte da poética do artista, que atua por ambigüidade e sugestão lúdica.

Diversos dos trabalhos criados por Plessi possuem uma relação com o local em que são expostos. Os trabalhos recebem nomes de cidades, como Veneza, Dover, Sevilla, Berlin, Paris, e o artista chegou até a realizar um trabalho chamado Amazônia. Neste trabalho, o artista projeta imagens de água sobre grandes troncos de árvores.

Entre os videomakers mais recentes, japonês naturalizado vietnamita Jun Nguyen-Hatsushiba produziu alguns dos trabalhos mais poéticos vídeo contemporâneo, nos quais a água é fundamental. No vídeo „Memorial Project Nha Trang, Vietnam: Toward the Complex - For Courageous, the Curious and the
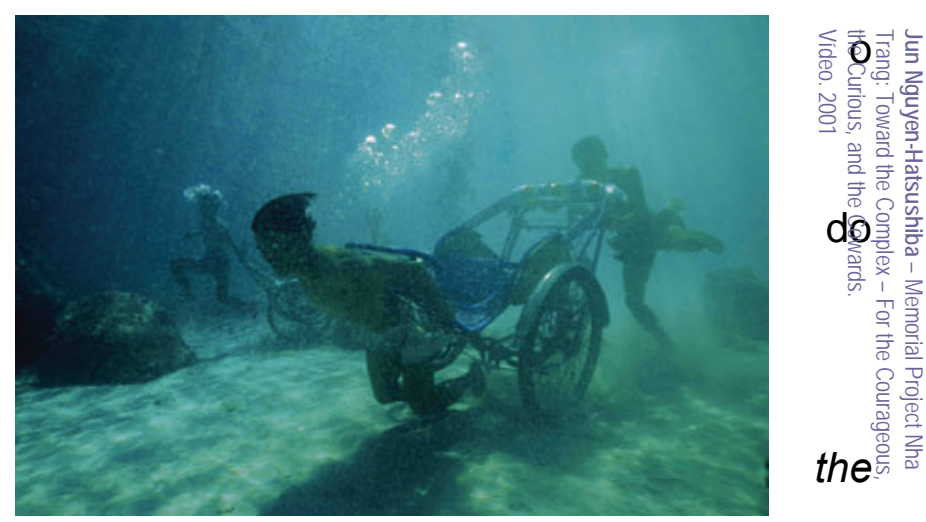

Cowards“ (2001), o artista capta imagens submarinas de uma série de 
mergulhadores que tentam arrastar riquichás no fundo do mar. Os mergulhadores empurram um pouco os carros e logo tem de voltar a superfície para respirar, voltando em seguida novamente ao fundo. A dificuldade física que enfrentam para desenvolver esta ação quase heróica ganha uma estranha leveza através das belíssimas imagens translúcidas que captam a flutuação e o nado submarino dos homens. Em uma sociedade em desenvolvimento como o Vietnã, as profissões tradicionais como os puxadores de riquichás e pescadores vão aos poucos desaparecendo e perdendo importância. Hatsushiba lhes devolve a dignidade ao mesmo tempo que cria uma metáfora poética sobre as dificuldades e as conquistas humanas.

Em outros de seus vídeos, as tradições orientais voltam a ser retratadas no meio sub-aquático. Em um deles os mergulhadores movimentam grandes dragões tradicionais e bolas que explodem soltando líquidos coloridos. Em outros vídeos, Hatsushiba filma também homens que constróem estruturas de acrílico transparente ou pintam telas embaixo d'água. Em todos eles, a água confere uma coloração luminosa especial às imagens, além de aumentar a dramaticidade das cenas, tornando o movimento dos homens mais lento e harmonioso. Além dos vídeos, o artista realiza também performances em que utiliza a água como material.

A artista alemã Christa Schuster capta imagens da água de maneira bastante diferente. Schuster documenta os rios alemães desde sua nascente até sua foz, focalizando apenas suas águas, eliminando outros elementos da paisagem. As variações de cor e velocidade das águas nos diferentes trechos dos rios são o assunto principal da artista. Para filmar seus vídeos, a artista percorre longas caminhadas e por vezes recolhe água, folhas, flores ou pedras que posteriormente são exibidas junto com os vídeos em instalações. A artista evita efeitos de edição de vídeo e prefere apresentar apenas a simplicidade das imagens da fluidez dos rios. Além do interesse ecológico, Christa Schuster busca uma comunhão existencial com a natureza, procurando observá-la imparcialmente, sem interferir sobre ela.

Já nos trabalhos da artista Janaína Tschäpe, a natureza aparece de maneira bastante dramatizada, como palco para mitos e lendas que oscilam entre a tradição romântica e a ousadia futurista. A artista encarna sereias, ondinas, melusinas e outros seres aquáticos em performances que são realizadas junto a paisagens naturais. O figurino e os objetos de cena criados pela própria artista porém destoam da figuração tradicional e apresentam uma estranheza típica da contemporaneidade. Sua retomada das alegorias aquáticas possui algo de anacrônico e causa um certo incômodo no espectador. 
O videoartista brasileiro Éder Santos também realizou trabalhos em que utiliza líquidos. Em um deles uma imagem de um nadador é projetada sobre uma superfície colocada no interior de um aquário. Em outro, imagens projetadas de água e vinho preenchem taças reais colocadas no interior de uma cristaleira.

Entre os artistas citados neste trabalho, diversos deles produziram vídeos em que água tem um papel importante, como por exemplo Nuno Ramos, Rivane Neuenschwander, Laura Belém, etc. Em minha produção recente também realizei vídeos sobre a água, como explanarei no capítulo que se segue.

É praticamente impossível reunir todos estes artistas sob uma única ótica. Fazer isso seria reduzir a potência individual de cada artista. Embora a água esteja presente em seus vídeos, cada um desenvolve sua poética pessoal e apresenta características individuais. Logicamente as questões gerais relacionadas à água estão presentes nesta produção, porém é a variedade de enfoques que thes confere riqueza.

\subsection{Outros líquiidos}

Até agora apresentei artistas que utilizaram água, líquidos mistos, nos quais a água é um dos componentes ou então outros líquidos não identificáveis ao observador, cujas características encontram diversos pontos em comum com a água. Há porém toda uma sorte de líquidos que também foram objetos da arte, que entretanto merecem ser analisados isoladamente devido às suas características específicas. Não pretendo apresentar aqui esta análise, já que para cada um destes outros líquidos seria possível desenvolver uma pesquisa de iguais dimensões à que realizei sobre a água. Apenas para que se possa ter uma idéia da variedade destes líquidos e de sua utilização na arte, enumero abaixo alguns exemplos.

O sangue foi utilizado em performances de Hermann Nitsch, Marina Abramovic, nos trabalhos de Karin Lambrecht e Joseph Beuys ou em esculturas como as de Marc Quinn. A urina foi retratada por fotos de Andrés Serrano, utilizada para realizar esculturas de Helen Chadwick ou em algumas pinturas de Andy Warhol. O óleo aparece em trabalhos de Noriyuki Haraguchi, Valie Export, Nuno Ramos, etc. O mercúrio líquido foi utilizado por artistas como Alexander Calder,Rebecca Horn, Laura Vinci, Roger Barnabé e outros.O veneno foi um dos materiais escolhidos pelo artista Donato Ferrari. Formol está presente sobretudo no trabalho de Damien Hirst. Waltércio Caldas realizou uma instalação em que utilizava leite. Márcia $X$ banhou-se com Coca-cola e leite condensado. Beuys gostava de mel.

A lista de artistas e líquidos seria infindável. Estudá-los com profundidade seria um outro mergulho... 


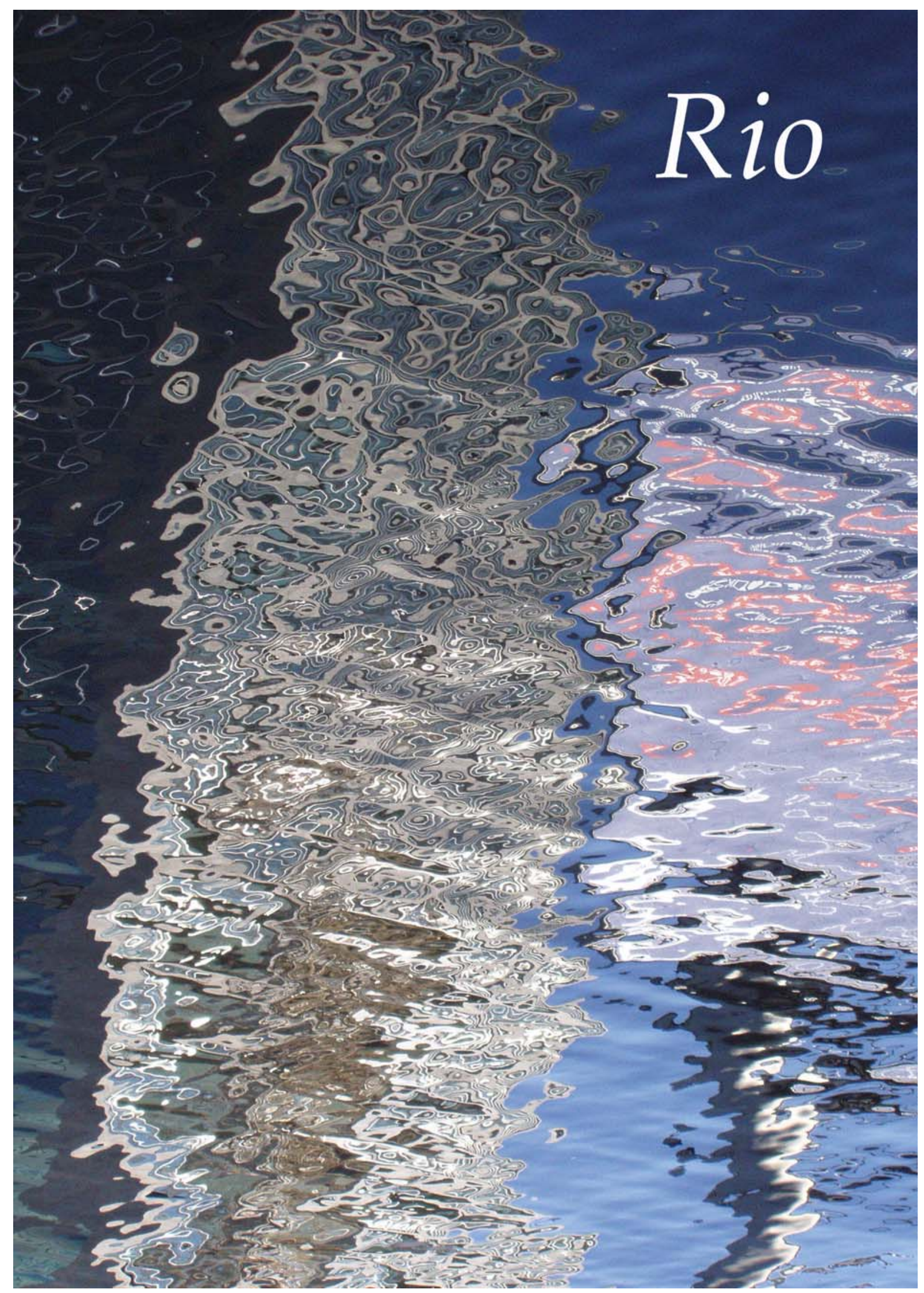




\section{O fluir de uma poética}

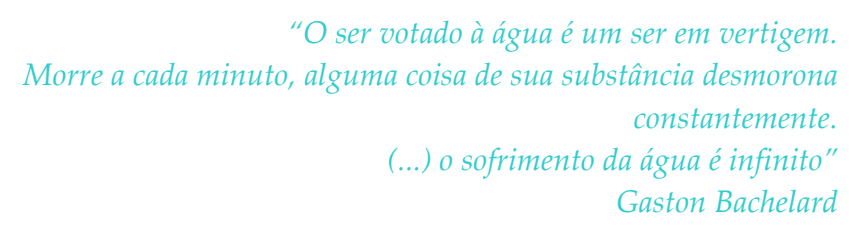

Desde 1993 tenho desenvolvido esculturas, instalações, fotos, vídeos e desenhos em que os temas e processos ligados à água, à transparência e ao vazio têm sido uma constante. Tenho interesse pela tridimensionalidade e as relações perceptivas, semânticas e fenomenológicas que as obras instauram no espaço.

O pensamento sobre a natureza no espaço contemporâneo e a reflexão sobre a condição do homem no ambiente urbano e tecnológico atual tem sido os meus principais pontos de interesse como artista. Embora meu trabalho possa carregar, em alguns casos, conteúdos autobiográficos e individuais, a exteriorização destas sensações busca uma universalização fundamentada na discussão da paisagem contemporânea como local para o desenvolvimento das relações humanas. A consciência de estar tratando da paisagem e das relações conflituosas entre homem e natureza no meio social urbano é algo que se torna mais claro para mim ao longo de meu desenvolvimento como artista. Se o início de minha trajetória artística é fundamentado intuitivamente em formulações quase intimistas, ao me aprofundar em minha poética e poder observá-la hoje como um todo em constante desenvolvimento, tornei-me consciente de estar lidando com questões relativas à paisagem e de estar buscando nelas não só a expressão de minhas sensações enquanto indivíduo, mas também a reflexão do homem sobre seu ambiente.

A partir de minhas escolhas artísticas realizadas até o momento, posso afirmar que quando trato do homem e de suas emoções, não é através da figuração antropomórfica que o faço, mas é principalmente a partir da observação de seu lugar no mundo e de seu ambiente. Se proponho uma crítica social em alguns trabalhos, ao expor por exemplo a poluição dos rios, meu interesse tem se voltado mais a demonstrar os efeitos causados ao ambiente do que a explicitar as relações econômicas e sociais que os provocam. Acima de tudo é o mundo como espaço e sua paisagem que me interessam. É neste ambiente que me situo e sobre este ambiente reflito.

Meu processo de criação é estimulado por dois movimentos. De um lado, o contato com materiais translúcidos ou líquidos me estimula à criação de obras que raramente se contentam com formas pré-estabelecidas em uma proposição 
projetual, mas buscam no próprio embate com a matéria as suas soluções formais, encontrando desvios e modificações no processo de sua fatura. O próprio desenvolvimento do trabalho atua neste sentido, uma vez que as descobertas surgidas no momento de confecção das obras são desdobradas freqüentemente em trabalhos futuros.

De outro lado, em muitos trabalhos, existe também uma proposição conceitual que norteia a constituição de uma obra ou de uma série de obras, estimulando a busca de determinadas soluções formais e sugestões semânticas. Assim, muitas vezes, no processo de criação de trabalhos, a palavra serve-me também como meio reflexivo, tanto como fonte de idéias para a conceituação das obras, quanto como forma de leitura e compreensão dos resultados obtidos ao longo da produção artística. É comum em meu processo criativo que muitas vezes uma idéia se apresente inicialmente incompleta e nebulosa, para posteriormente, a partir da relação com a matéria, ser esclarecida e ampliada. Em alguns trabalhos as palavras são também incorporadas à apresentação final da obra, instaurando paradoxos ou tautologias. A imaginação criadora dos trabalhos articula-se paralelamente a partir de diferentes meios, quer sejam a escrita, a visualização e projeção de imagens, minhas memórias afetivas, as memórias e significações sugeridas pelo espaço expositivo ou as relações corpóreas e físicas proporcionadas pelo contato com a matéria.

Os trabalhos têm buscado geralmente um envolvimento estético, emocional, conceitual e sensorial do espectador. Procuro me dirigir ao espectador comum e sensível, não necessariamente ao especialista em artes visuais. Embora em alguns trabalhos a conceituação semântica possa ser complexa e sofisticada, incorporando referências pessoais ou históricas e por isso guardando para si um certo mistério, acredito que a porta de entrada para a fruição da obra encontra-se em sua apresentação visual e material, e é através dessa apresentação que procuro chamar a atenção do observador.

Assim, em meus trabalhos, é em primeiro lugar pela sedução visual que o espectador é levado a buscar formulações conceituais e não o contrário. Não exijo do observador que conheça previamente minhas idéias conceituais para "entender" a obra, mas que apenas se atreva a ter vontade de desvendá-las. Procuro também não propor charadas intrincadas, mas mistérios saborosos.

Minhas obras tem se desenvolvido a partir de um núcleo poético formado basicamente pelas idéias de transparência e vazio e pela observação da paisagem no espaço contemporâneo. Em minha produção mais recente, a água tem sido o meio utilizado para a reflexão e para a expressão destes conceitos. Ao longo de meu desenvolvimento artístico, pude intuir a partir de minha relação com a matéria 
líquida, uma série de conceitos que busco discutir em minha produção. Nestes conceitos, relaciono os processos físicos e materiais da água a determinadas concepções semânticas, que constituem o cerne poético da obra. Com a realização desta pesquisa de doutorado, pude perceber que estes conceitos, nascidos inicialmente no momento da produção e da reflexão sobre o meu próprio trabalho como artista, poderiam ser estendidos a diversos outros artistas contemporâneos que também utilizam água em suas obras. Assim, o que era inicialmente uma percepção individual, pode se tornar uma narrativa mais universal, que serve para comentar o trabalho de diversos artistas contemporâneos, sem deixar entretanto de salientar suas nuances e diferenças. A explanação detalhada destes conceitos, bem como suas implicações teóricas e exemplificação com o trabalho dos artistas será apresentada no próximo capítulo deste trabalho. Por ora, pretendo apresentá-los ainda de maneira sucinta, para que o leitor possa já tê-los em mente ao tomar contato com minha produção como artista. Tais conceitos são:

- transparência como evidência do vazio. Um espaço preenchido por um meio transparente, embora cheio, evidencia o seu vazio, já que não oferece opacidade à visão. Um material transparente aparece de maneira quase imaterial, já que sua presença não impede a visualização de seu entorno. Assim, a relação da obra com o espaço vazio que a circunda é quase contínua, incorporando-o e sendo incorporada por ele.

- reflexão e refração como representação e virtualidade. Uma imagem ou um objeto refletido e refratado no meio aquático perdem seus contornos definidos e sua unicidade. Sua multiplicação e distorção nos sugere a existência de mundos virtuais, que embora entranhados na matéria líquida, e portanto não descolados do mundo material, assumem a condição de imagens etéreas e cambiantes que nos confundem a percepção. O corpo físico dos objetos passa a parecer incerto e começamos a duvidar do que nosso olho vê.

- flutuação como elevação. Pela imersão no meio líquido, alguns materiais apresentam uma relação com a gravidade diferente da que experimentamos fora d'água. Parecem assim perder peso e atingir uma espécie de elevação.

A busca de uma transcendência tem sido o mote de grande parte da produção artística desde seu surgimento. A idéia de um mundo espiritual e sem matéria acompanha o homem desde as primeiras teorias metafísicas. A flutuação de objetos pode em algumas das obras sugerir a idéia de elevação espiritual. Não se pretende no entanto fazer uma alegoria de teorias metafísicas ou sua defesa, mas apenas utilizá-las como referência poética. Não se deve esquecer que embora haja flutuação no meio aquático, ela ainda se dá no mundo material pelas tensões envolvidas nos processos físicos e não em um mundo superior de idéias. 
- fluidez como transformação. A ausência de uma forma fixa nos materiais líquidos, fazendo com que eles assumam diferentes configurações de acordo com o local em que estão contidos, assinala uma certa instabilidade. A facilidade com que materiais líquidos mudam para o estado sólido ou gasoso também contribui para esta sensação instável. A fluidez dos líquidos, que se movimentam facilmente em função da gravidade também acentua a sua característica de material em permanente transformação. A idéia de transformação, por sua vez, está intimamente ligada à questão da passagem do tempo e da modificação dos espaços. O tempo, tanto como produtor de uma memória que impregna os lugares, quanto como agente que atua sobre a obra, tem sido uma questão poética bastante presente em alguns de meus trabalhos. Da mesma forma, os fluxos e memórias em transformação presentes nos espaços expositivos têm servido como material para a criação de diversos trabalhos site-specific que pude desenvolver.

Minha produção pode ser dividida em dois momentos. Em seu momento inicial realizei trabalhos com materiais bastante variados que se articulavam em esculturas e instalações. Embora muitas vezes a referência ao meio aquático e o interesse pela transparência já existisse, ainda não havia experimentado propriamente o meio líquido. A partir da criação dos primeiros trabalhos com água ("Algo/Alga" e "Afogo"), iniciei uma segunda etapa em minha produção que foi movida pelo desdobramento e aprofundamento nas questões suscitadas pelo elemento água. Decidi habitar por um certo tempo este terreno líquido. Em grande parte dos trabalhos que realizei, em especial nas instalações, utilizei a água como material ou como tema. Mesmo naqueles em que a água não aparece, pode-se encontrar concepções poéticas que se relacionam a características da água, como a fluidez, a transparência ou a sua origem natural. Embora meu interesse pela água ainda seja bastante grande, pois vislumbro diversas possibilidades de novos trabalhos surgidos daí, procuro não encarar a utilização do material líquido como uma exigência obrigatória, mas, ao contrário, pretendo permitir que outros materiais e questões poéticas possam ser incorporadas à constituição do trabalho, que é guiado pelo seu próprio desenvolvimento.

Em minha obra mais recente, em especial após minha vivência na Alemanha, tem crescido minha produção em fotografia e vídeo. Na verdade, o interesse por atuar em diferentes mídias está presente desde o ínicio de meu trabalho, tendo realizado meu primeiro vídeo em 1998. O aumento de minha produção em vídeo e fotografia nos últimos anos não se deve a um modismo ou à simples influência de uma vivência no exterior, mas sim a uma maior possibilidade de acesso à tecnologia. Creio que minha produção articula-se poeticamente independentemente do meio em 
que se realiza, procurando considerar em cada mídia suas particularidades e limitações.

Em meio a minha produção artística, posso encontrar determinados núcleos que explicito a seguir. Tais núcleos, entretanto não constituem categorias isoladas, nem obedecem necessariamente uma ordem cronológica, mas se interrelacionam e transpassam. 


\subsection{Os rios}

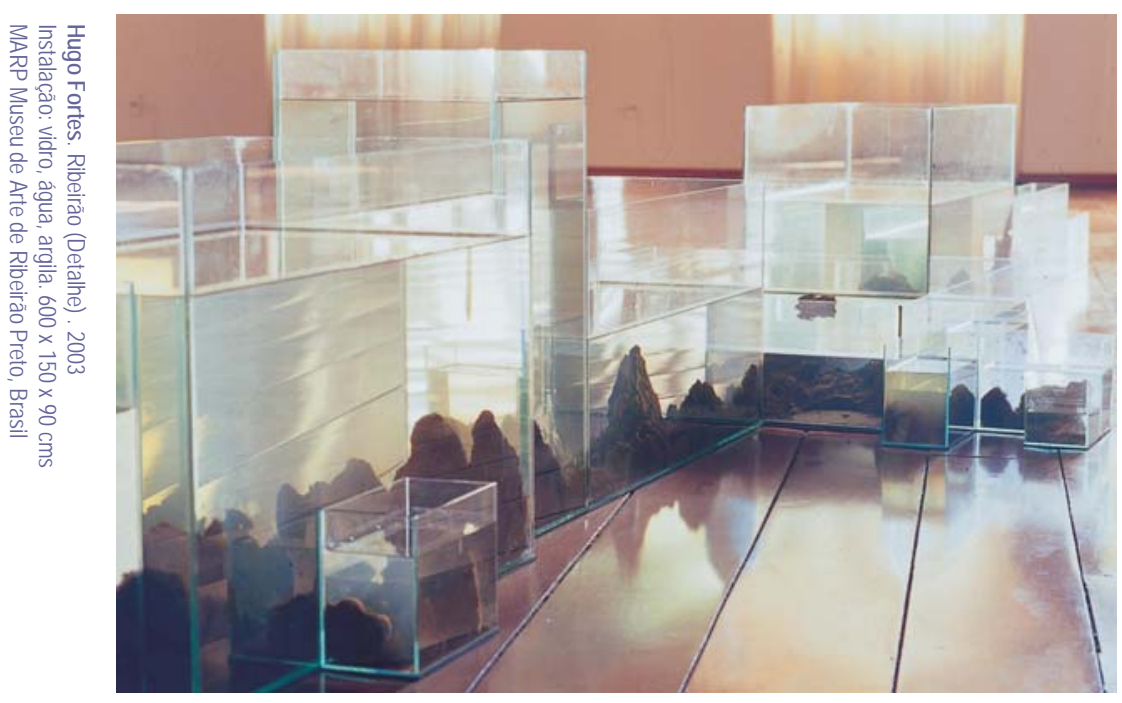

Os rios são caminhos mais antigos que a redondeza da terra. Eles descem horizontes seguem sozinhos no ar.

E a bela asa em pleno vôo, entre o partir e o chegar, sem se importar com fronteiras. Mas como se há de parar?

Mario Quintana

Em 2003, realizei duas instalações ("Ribeirão" e "Pirapora") com uma grande quantidade de aquários enfileirados, que procuravam reconstruir o leito de rios no espaço da exposição. Três anos mais tarde, voltei a visitar o tema, na instalação "Onde", acrescentando algumas modificações.

O primeiro trabalho desta série foi "Ribeirão", exposto em junho de 2003, na Exposição Espaço Comum no MARP - Museu de Arte de Ribeirão Preto. O trabalho foi concebido especificamente para o local e teve como inspiração o próprio nome da cidade em que foi exposto. A instalação reunia cerca de 36 aquários de diferentes tamanhos que se enfileiravam em uma espécie de "Ribeirão" de cerca de 6 metros de comprimento. Dentro dos aquários havia água em diferentes níveis e argila que funcionava de certa forma como as margens do ribeirão. Como nos trabalhos que realizei anteriormente, havia uma série de reflexos que multiplicavam as imagens reais e confundiam a visão do observador. As margens do rio, feitas de argila, eram seccionadas e espelhadas pelas paredes de vidro dos aquários, causando uma sensação ao mesmo tempo de continuidade e interrupção. Sob os aquários foi colocada uma superfície de borracha preta, que além de conferir qualidades plásticas ao trabalho, remetia ao nome Ribeirão Preto. 


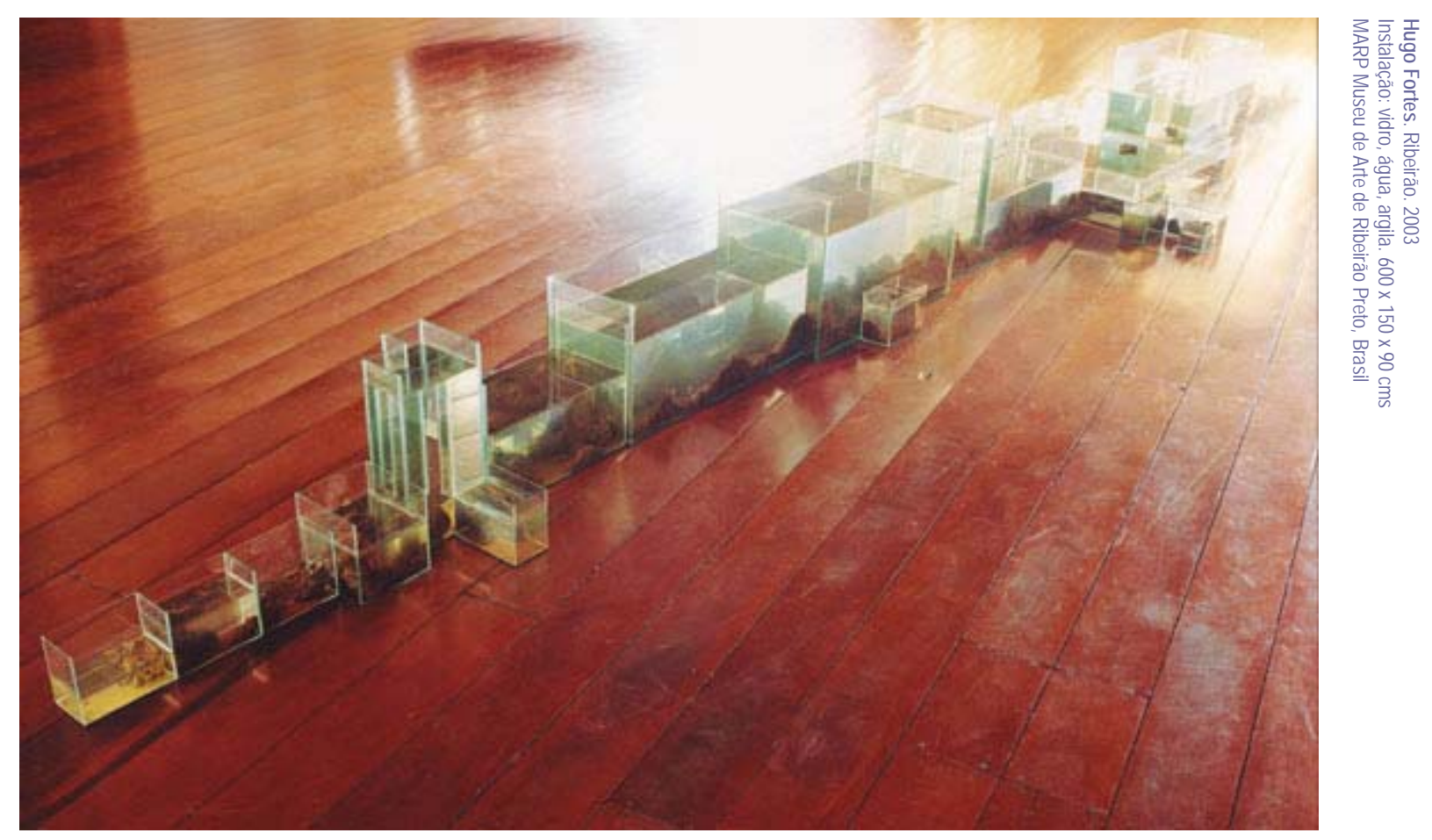

Neste trabalho demarquei um eixo retilíneo no qual se enfileiravam os aquários.

Esta linha reta, que reforçava a artificialidade arquitetônica do rio, era suavizada pela sinuosidade das margens de argila no interior das caixas de vidro. Embora a água se apresentasse parada, a noção de fluidez era sugerida pela extensão do trabalho. $O$ fato do "Ribeirão" apresentar-se compartimentado, descontínuo e fragmentado em caixas de vidro remetia à idéia de um rio limitado pelo avanço urbano. $O$ trabalho buscava relembrar o conteúdo poético contido no nome da cidade e ao mesmo tempo provocar uma reflexão sobre o cerceamento da natureza pela cidade contemporânea. Ao conversar com moradores da cidade de Ribeirão Preto, pude perceber que poucos deles conheciam a história ou a localização do rio que havia dado nome à cidade. Procurei assim repor estas questões e sugerir a discussão sobre a alteração da paisagem causada pelo desenvolvimento urbano da cidade.

O segundo trabalho desta série de instalações foi "Pirapora", apresentado em outubro de 2003 no Memorial da América Latina, em São Paulo. Ao invés do eixo retilíneo de "Ribeirão", "Pirapora" distribui-se de maneira mais sinuosa, relacionando-se com o espaço arquitetônico circular da sala de exposições projetada por Oscar Niemeyer no Memorial da América Latina. Esta sinuosidade, é no entanto ainda marcadamente geométrica e construída, já que os aquários são encostados uns aos outros paralelamente ou perpendicularmente. A matéria argilosa de seu interior confere-lhes entretanto uma certa organicidade. Além da argila e da água, acrescentei a esta instalação um novo material: a cal. Sua presença fez com que ficassem flutuando pequenos fiapos sobre a água, lembrando as espumas brancas dos rios poluídos. O título faz uma alusão ao problema da poluição do rio Tietê na 
cidade de Pirapora do Bom Jesus, fato que na época da criação do trabalho estava sendo bastante discutido nos meios de comunicação. $O$ aspecto esbranquiçado da água foi ressaltado pela colocação de um fundo de borracha branca sob os aquários e pela proximidade do chão de mármore branco no qual foi instalado o trabalho. A relação semântica entre o trabalho e seu entorno também é reforçada pelo nome do bairro onde se localiza o Memorial da América Latina: Água Branca.

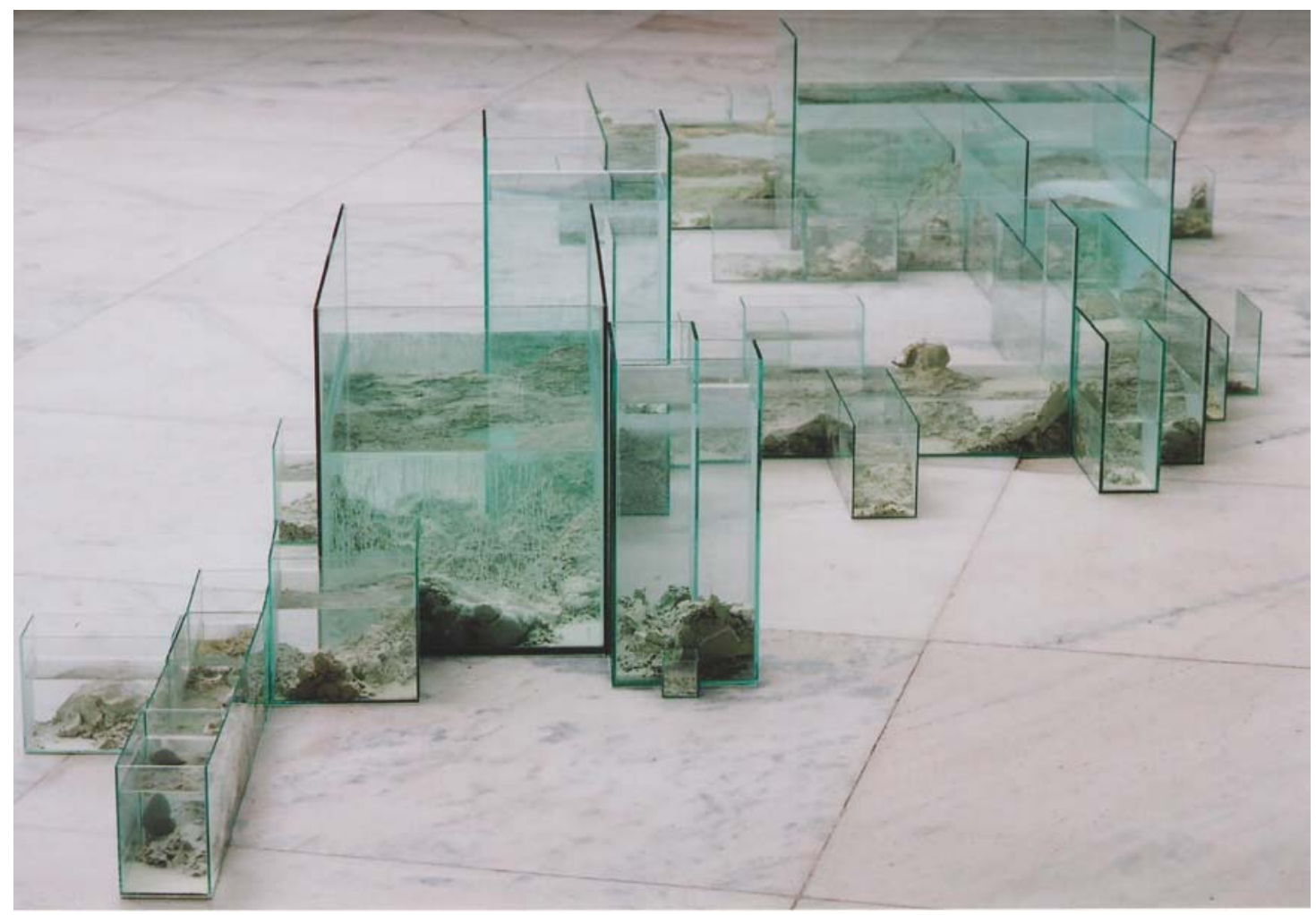

O terceiro trabalho desta série foi realizado três anos depois, após minha vivência em Berlim. O trabalho "Onde" apresenta uma série de elementos novos em relação aos anteriores. Ao invés de estar solto no espaço, o trabalho inicia-se e termina nas paredes que o contém, integrando toda a sala em sua constituição. Sua distribuição assemelha-se à sinuosidade de "Pirapora", porém apresenta-se ainda mais serpenteante, fragmentada e entrecortada. Seu caminho isola determinadas áreas da sala, descrevendo uma barreira ao espectador, que deve seguir seu curso para poder observá-lo. 


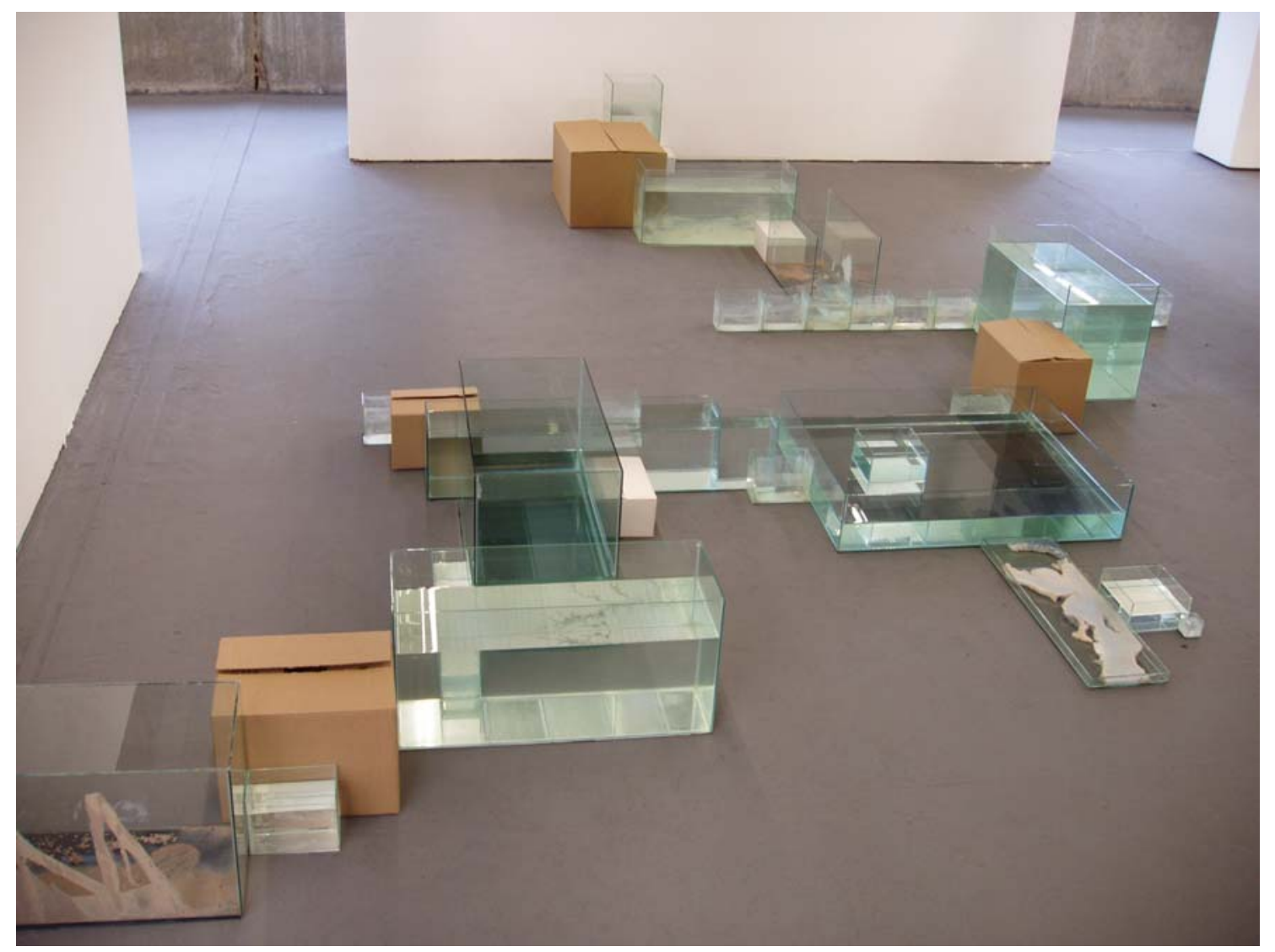

Ao invés das margens de argila que davam uma certa unicidade aos trabalhos "Ribeirão" e "Pirapora", optei em "Onde" por uma fragmentação maior e um esvaziamento visual das caixas de vidro. Enquanto nos trabalhos anteriores busquei uma limpeza cristalina da água e das paredes de vidro dos aquários, no trabalho "Onde" incorporei restos de argila, parafina e cal deixados pelo uso dos aquários, demonstrando suas marcas do tempo e seu desgaste. Incluí também alguns novos elementos. O mais marcante foram caixas e caixotes de papelão nas cores parda e branca.

Tais caixas, além de interromperem o fluxo cristalino que se dava entre os aquários, acrescentaram um caráter mais provisório ao trabalho. A caixa sugere a embalagem de algo transportável e móvel, que está apenas estacionado provisoriamente em algum local. Assim como os aquários, tais caixas servem para conter; seu caráter entretanto parece mais estável do que o dos aquários, já que protegem e ocultam ao invés de revelar seu conteúdo.

O acúmulo de caixas de papelão, juntamente com as caixas de água, sugerem um depósito de algo parado em vias de ser transportado e movido. O espaço do depósito é o local das coisas sem lugar, é um espaço de trânsito, ao qual as coisas não pertencem. Se "Pirapora" e "Ribeirão" relacionavam-se a rios e locais 
específicos, "Onde" é um rio sem referente, sem local, sem nascente e sem rumo, que apenas se instala transitoriamente em seu fluxo interrompido.

O próprio título do trabalho sinaliza esta direção transitória. "Onde" não está em lugar nenhum, busca um local incerto no mundo. Algumas circunstâncias práticas levaram-me a pensar nesta questão. Em "Ribeirão" e "Pirapora", rios reais reclamam para si um local no mundo; o lugar que a sociedade lhes reserva é o do esquecimento e o da poluição. Ao invés de enxergá-los como fonte de vida ou entidade espiritual natural, a sociedade contempôranea parece preocupar-se mais em canalizar e cercear seus rios em concreto, encarando-os apenas como recursos para extração, locais de despejo de detritos ou como estorvo para o traçado de sua paisagem urbana. Assistimos constantemente as discussões a respeito do deslocamento dos traçados dos rios, que embora muitas vezes necessários, transformam todo o ambiente natural. O rio, antes demarcador de territórios e sinal característico da paisagem, pode ser hoje transportado, canalizado, repartido, "encaixotado". Estas circunstâncias aparecem com mais premência no trabalho "Onde".

Creio que minha vivência por dois anos na Alemanha contribuiu para minha percepção deste processo. A natureza na cidade européia aparece aos olhos de um brasileiro como extremamente dominada e colonizada, quase passível de ser contida em caixas artificialmente. Além disso, o sentimento do estrangeiro, assim como o sentimento de quem retorna ao país de origem após um longo tempo aponta para uma maior sensação de um não pertencimento a um lugar, um sentimento de transitoriedade e flutuação no mundo. As caixas de transporte de "Onde" sinalizam também esta sensação. Assim, não é apenas a um rio específico que me refiro neste trabalho, mas a um sentido de fluidez, de fluxo e de transição.

Embora a disposição espacial e a proximidade formal das peças que compõem a instalação "Onde" permitam que ela seja observada como um todo, cada peça apresenta suas particularidades e autonomia e pode ser vista também isoladamente. Assim, em algumas unidades observa-se com destaque as manchas deixadas no vidro pela ação do tempo e pelos restos ali acumulados; em outras o que se destaca é o contraste entre os diferentes fundos pretos e brancos dos aquários e as transparências e jogos ilusórios proporcionados pelos diferentes níveis de água. Há aquelas ainda nas quais o que aparece é a flutuação de aquários dentro de outros ou então o espelhamento de imagens colocadas sob o fundo das caixas de vidro. Em duas destas caixas, observam-se imagens que se assemelham a pequenos mapas fluviais, a àrvores ou a sistemas circulatórios com suas veias e bifurcações. Este belo desenho orgânico ramificado, não foi no entanto por mim traçado, mas sim 
encontrado como obra de cupins que comeram o fundo das embalagens dos aquários, deixando ali as marcas de sua ação.

Esta ação denota, por um lado, a corrosão do tempo e a morte das coisas armazenadas, e, por outro lado, o avançar devorador da vida e o seu germinar entre o silêncio.

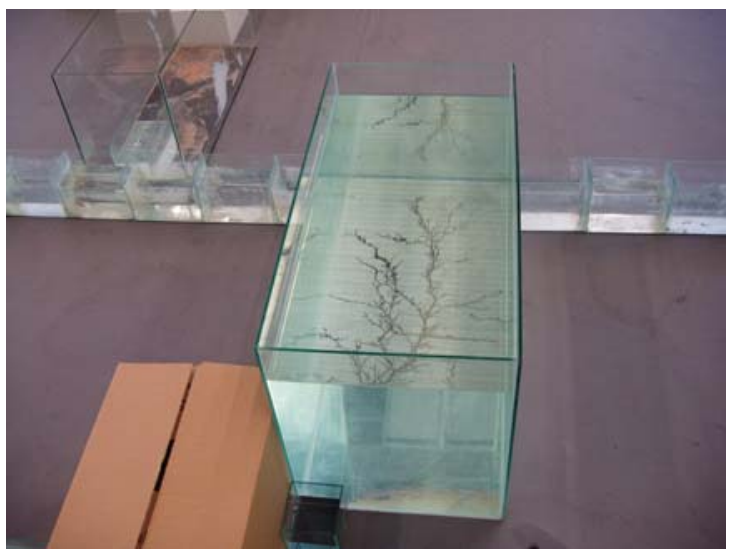

O fato do traçado dos cupins se assemelhar a ramificações de rios, não é algo que se possa projetar ou fabricar, mas é um destes mistérios que somente a arte pode revelar. Mais do que falar de rios ou de realizar proposições ecológicas, creio que o trabalho "Onde" tece comentários sobre o fluir e o estagnar da vida na sociedade urbana contemporânea.

Ao retomar o tema dos rios, que, como expus nos capítulos iniciais deste trabalho, teve papel definitivo nas diferentes definições do conceito de paisagem ao longo da história da arte, incorporo as significações acumuladas no decorrer do tempo e acrescento as percepções e circunstâncias da contemporaneidade.

Estes rios não só serpenteiam como nos quadros renascentistas, mas também são interrompidos em seu fluxo geometrizado; são ao mesmo tempo rios para transporte e trânsito, como os rios holandeses e venezianos, assim como rios transportáveis e transitórios; não apenas incorporam a tranqüilidade, os reflexos óticos e as variações de luz das águas impressionistas, mas desdobram-se em construções que confundem a percepção visual, flutuando entre o minimalismo asséptico e a expressão orgânica. Isto não os torna mais ou menos potentes, acumulam apenas os sedimentos da história, levando-os em sua corrente, traçando novos caminhos e fluindo como podem. 


\subsection{Horizontes}

Horizontes vem depois depois das paredes

Atravessam janelas

Há horizontes que despencam

Quedamos horizontais

Pontos de fuga para linhas mortais

Hugo Fortes

Texto integrante da exposição

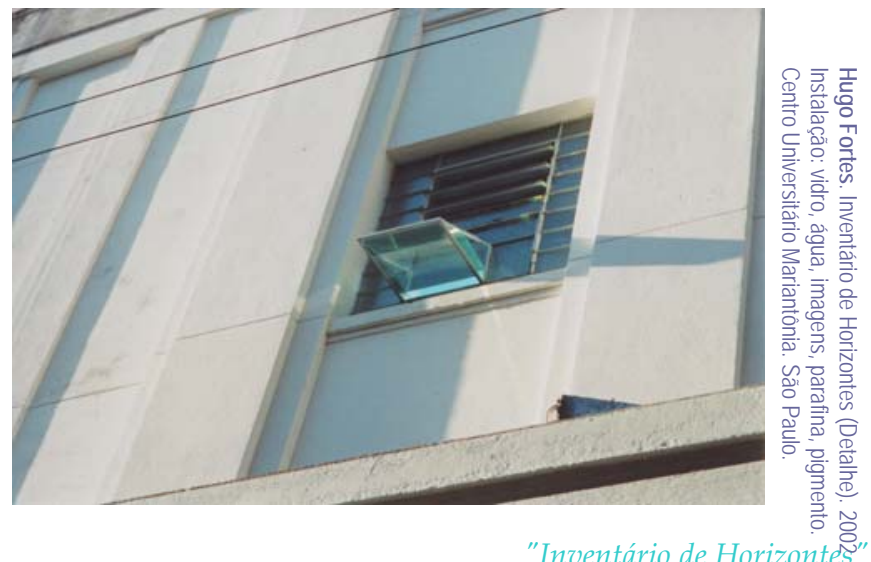

Assim como os rios, também os horizontes foram fundamentais na constituição da noção de paisagem na história da arte. Linhas determinantes para a construção da perspectiva renascentista, rebaixados de maneira a evidenciar a amplidão do céu entre os barrocos holandeses ou enevoados e incertos entre os românticos, os horizontes sempre simbolizaram uma vontade de enxergar ao longe, um desejo de profundidade e expansão. Na metrópole contemporânea este desejo parece estar condenado a se fechar em apartamentos. A vista já não encontra mais muita possibilidade de se expandir ao longe, mas enxerga por todos os lados arranha-céus como anteparo. Tal situação levou-me a desenvolver alguns trabalhos que refletem sobre esta condição.

Em maio de 2002 realizei a instalação "Inventário de Horizontes" apresentada como exposição individual no Centro Universitário Maria Antônia. A instalação consistia de uma série de aquários de diferentes formatos, com água, parafina, imagens, pigmento e outros materiais, que interferiam em pontos específicos do espaço expositivo (janela, portas, quinas) de maneira a evidenciar o vazio, utilizando a transparência e as reflexões e distorções produzidas pela água. As linhas que separam a água em repouso dos aquários do espaço aéreo, estabeleciam "horizontes" em diferentes alturas, servindo como apoio poético para o olhar. 


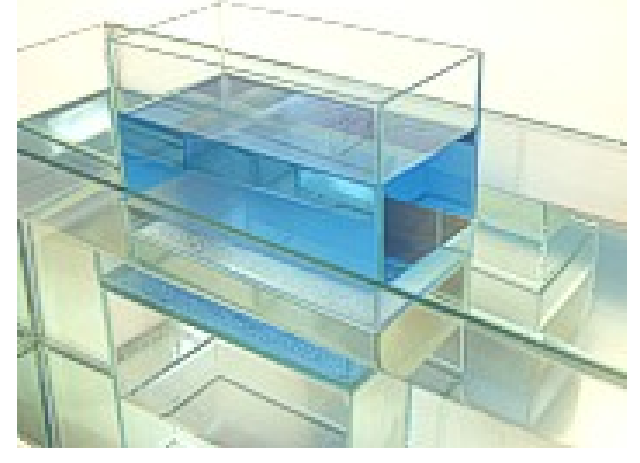

As diminutas proporções da sala também serviram ao desenvolvimento poético do trabalho. Sua condição como local pequeno e fechado ofereciam grande contraste ao tema da amplidão e expansão sugerida pelo horizonte. Substituí um dos vidros opacos da única janela existente na sala por um aquário que foi colocado do lado externo do prédio. Isto criou a possibilidade de se olhar para a paisagem externa da sala através de um horizonte artificial produzido pela linha d'água no interior do aquário. As imagens da paisagem externa eram refletidas e vistas invertidas pelos efeitos da água. Além disso, o sol era filtrado pelo aquário prismático, produzindo efeitos de arco-íris no interior da sala e na parte externa do prédio. Procurei explorar ao máximo as condições arquitetônicas da sala, colocando aquários em locais pouco prováveis, sobre a porta de entrada, acompanhando quinas e reentrâncias da parede ou entrando por baixo de uma porta fechada existente no local. Neste trabalho, a questão espacial tornou-se bastante relevante já que, ao invés dos aquários funcionarem como esculturas isoladas, estes foram produzidos de modo a se adequar especificamente às medidas e ao espaço arquitetônico local. A leitura do trabalho dava-se não só pelo mergulho do olhar do observador no ambiente interno do aquário, mas na relação deles com a sala e os reflexos e distorções que estes causavam na arquitetura.

Além das caixas de vidro com água, havia também uma pequena barra de vidro presa horizontalmente na parede sobre a qual foi escrito o texto poético que se encontra no início deste item. A palavra acrescenta possibilidades poéticas de apreensão do trabalho, não só através da introdução deste texto, mas também no próprio título da obra. "Inventário de Horizontes" apresenta um duplo sentido. Inventário é ao mesmo tempo o levantamento dos bens de um morto e pode portanto relacionar-se ao desaparecimento dos horizontes na cidade contemporânea, assim como pode ser entendido como um neologismo que denota o coletivo de horizontes inventados artificialmente.

A instalação "Inventário de Horizontes" completava-se com uma série de pequenas fotos que foram colocadas alinhadas em uma extensa linha horizontal no espaço externo da sala. Estas fotos, todas apresentadas em um tom azul intenso, retratatavam linhas horizontais formadas por diferentes situações arquitetônicas, como prédios, quinas, desenhos no solo, etc. Estas barreiras para o olhar pertencentes à paisagem construída urbana eram transformadas em linhas abstratas que formavam horizontes artificiais. 


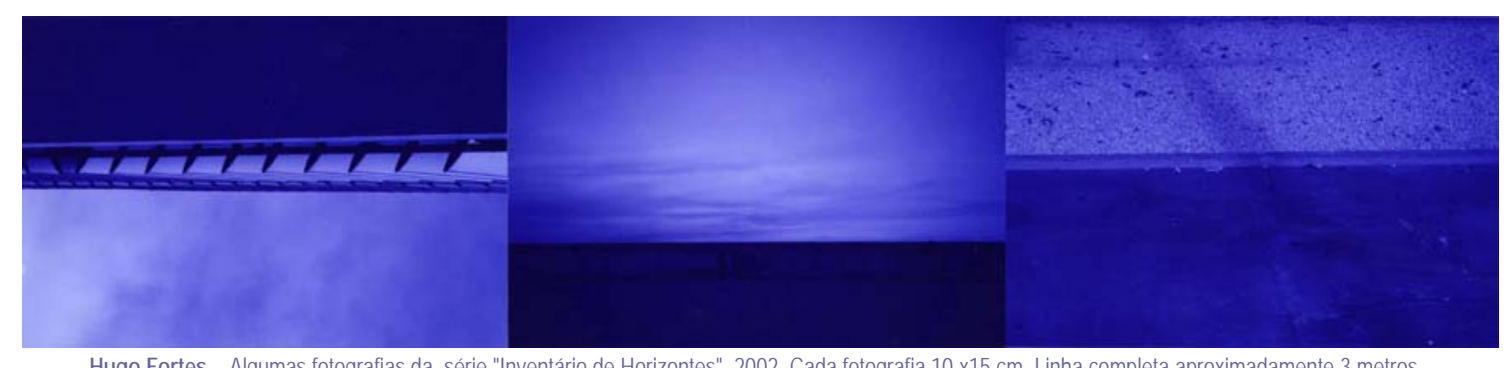

Hugo Fortes - Algumas fotografias da série "Inventário de Horizontes". 2002. Cada fotografia 10 x15 cm. Linha completa aproximadamente 3 metros.

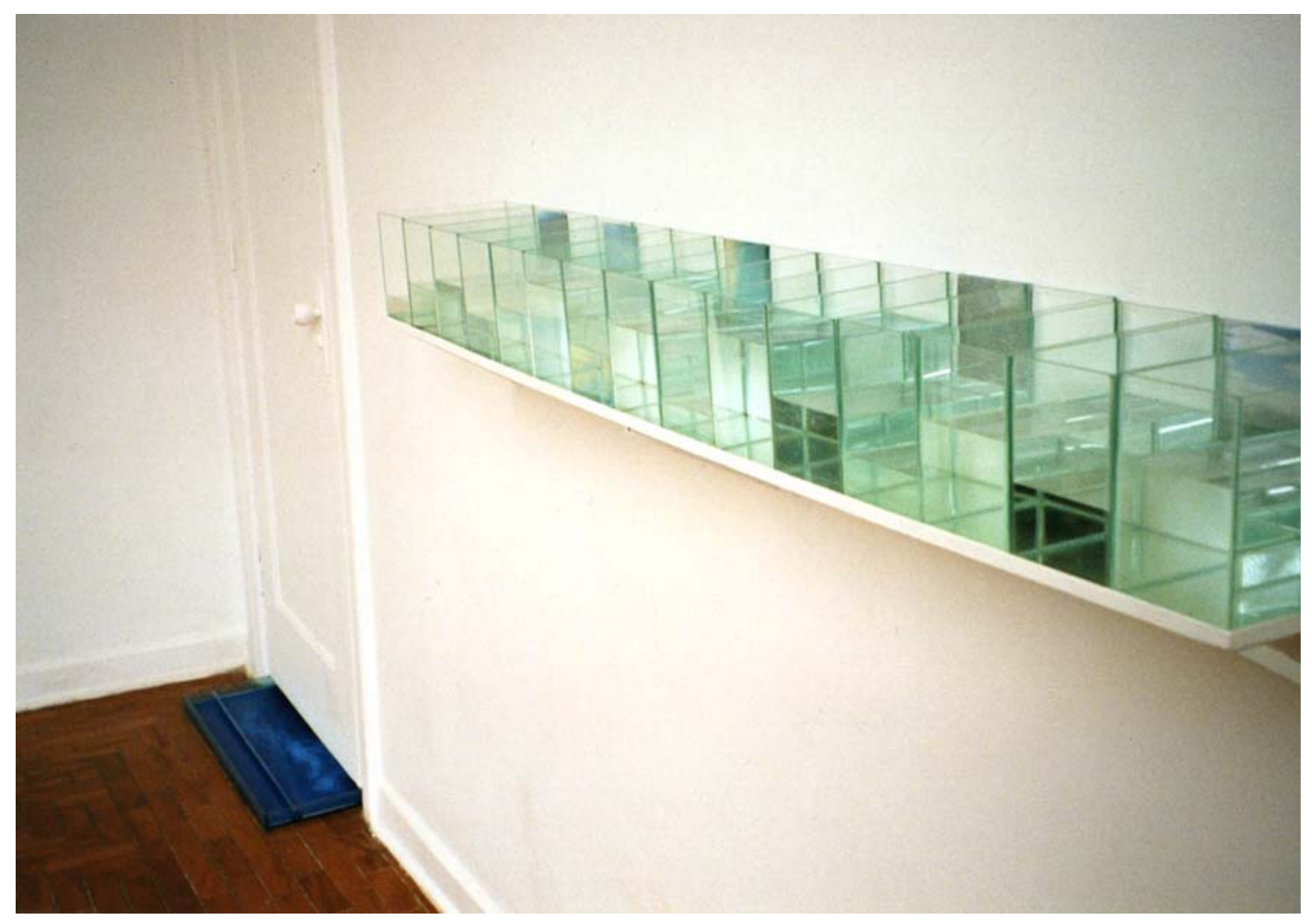




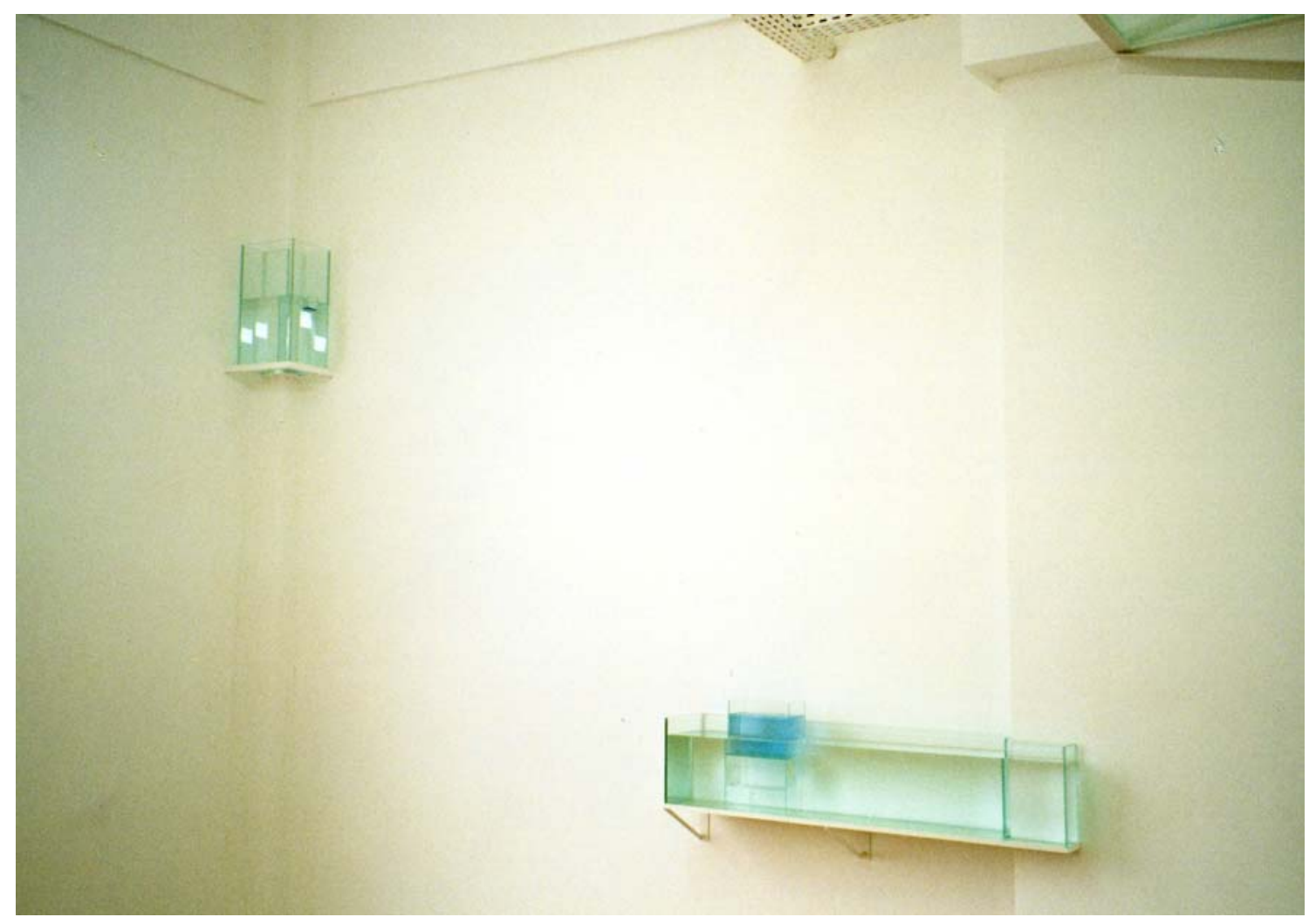


Embora não tenha utilizado água no trabalho "Através", realizado em 2003 em Belo Horizonte, o interesse pelas idéias de horizonte e transparência voltou a se manifestar. Assim como em "Ribeirão", o nome da cidade serviu como fonte poética para o trabalho. Ao invés da água, utilizei barras

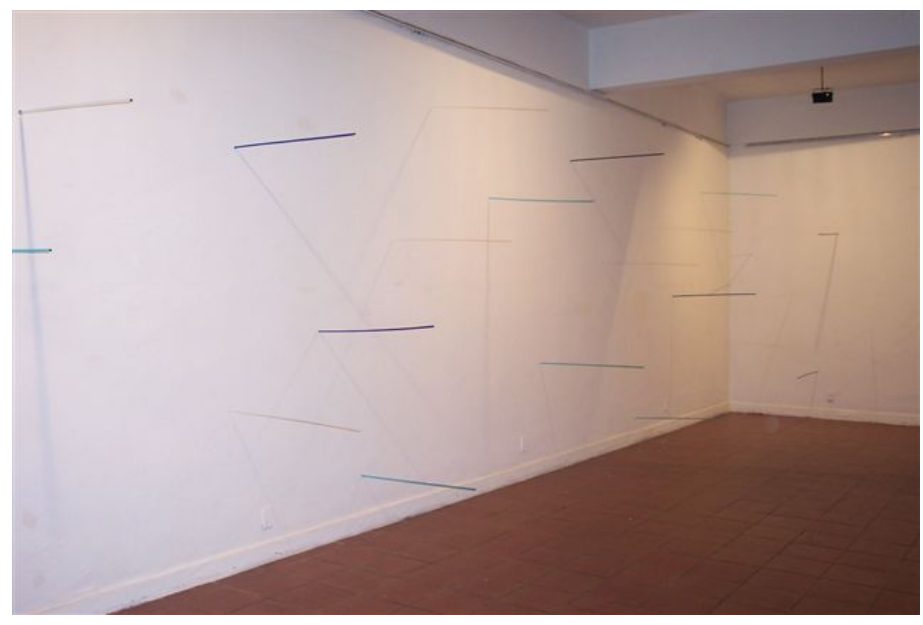

vidro transparente e incenso. Em uma grande sala dispus perpendicularmente às três paredes principais uma grande quantidade de barras de vidro transparente com cerca de um metro de cumprimento por 0,5 a 2,5 cms de diâmetro. Estas barras de vidro, incolores ou em duas tonalidades de azul, eram enfiadas nas paredes e avançavam em direção ao espectador criando um espaço em que ele não poderia entrar, sob o risco de ser espetado por elas. O fato das barras estarem todas paralelas horizontalmente retomava de alguma maneira a idéia de horizonte que havia sido tratada no trabalho "Inventário de Horizontes". Ao mesmo tempo, o fato de estarem presas à parede apenas em um pequeno ponto onde eram enfiadas, aumentava a idéia de flutuação, como se elas estivessem suspensas no ar e cortassem as paredes. Embora o trabalho se apresentasse leve visualmente, podia ser notada uma certa agressividade a medida que estas barras funcionavam como grandes agulhas prestes a espetar o observador. O vazio era evidenciado pela leveza do trabalho e pela maneira como as barras se projetavam ativando o espaço da sala. A luz tinha papel determinante nesta instalação, provocando sombras das barra de vidro, que se alongavam como desenhos ao longo das paredes. Como complemento da exposição, realizei na parede oposta da sala uma pequena instalação de parede com uma grande quantidade de incensos que, espetados também perpendicularmente à parede, formavam por sua disposição espacial um desenho circular. Deveria ser aceso um incenso por dia, consumindo o trabalho até o final da exposição. Tempo e vazio foram as questões principais destes trabalhos em que a idéia de linhas no espaço foi bastante explorada.

Os horizontes de "Através" apresentam-se ao mesmo tempo frágeis e ameaçadores, prontos a se quebrar a qualquer momento. As barras de vidro suspensas horizontalmente, por um lado avançam sobre o corpo e intimidam a visão, por outro lado expandem-se como linhas abstratas que cortam o espaço projetando-se imaginariamente para além de seus limites. 


\subsection{Peso, leveza, flutuação}

\begin{abstract}
(...)Afinal, a matéria principal que escolheu é um fluido, a água, que põe em suspensão as demais propriedades físicas - em especial aquela propriedade primeva, o peso. Tudo em seu trabalho, de fato, flutua, deve flutuar, e só funciona se alcançar esta flutuação - desde os aquários até as linhas de seus desenhos. Esta espécie de dúvida líquida contagia a própria posição do espectador, que olha os trabalhos de fora mas gostaria de conhecê-los imerso, desde dentro.
\end{abstract}

\section{Nuno Ramos}

Texto sobre o trabalho de Hugo Fortes escrito no catálogo da exposição Dúvida Líquida, apresentada na Galeria Valu Oria, 2002.

Uma das idéias mais recorrentes na minha produção como artista é a noção de flutuação. A sensação de estar imerso na matéria líquida, flutuando sem sentir o peso do corpo, deixando-se vagar pela substância aquática, como que a voar no meio cristalino é algo que me acompanha desde meus mergulhos em piscinas da infância. O prazer em observar como os corpos ganham novas propriedades no meio aquático, recebendo forças de uma ordem diferente da gravidade a que estamos acostumados e ao mesmo tempo modificando sua aparência pelas artimanhas ópticas da água, é o que me moveu para a realização de uma grande quantidade de obras.

Desde meus primeiros trabalhos com água, experimentei lidar com as oposições peso/leveza e transparência/opacidade. Inicialmente tais conceitos apresentaram-se em forma de paradoxos perceptivos, como na instalação "Fossem os vazios mais leves" ou no trabalho "Afogo"; num segundo momento, embora estas propriedades continuassem a atuar sobre as obras, não me pareceu mais necessário explicitá-las de maneira tão dualista, e passei a lidar com elas de forma mais livre e poética, utilizando-as como forças naturais que constituíam paisagens - como na série de aquários sem título.

A instalação "Fossem os vazios mais leves", apresentada no SESC Pompéia, em São Paulo, é composta de três pequenos aquários revestidos parcialmente com folhas de chumbo, deixando algumas aberturas por onde se observa seu interior. Estes pequenos aquários são cheios de água, parafina, lentes de aumento e chumbos de pesca em formato piramidal. $O$ formato dos chumbos de pesca reaparece em diversos elementos do trabalho, como "pesos" feitos de parafina, que, na verdade, bóiam. 


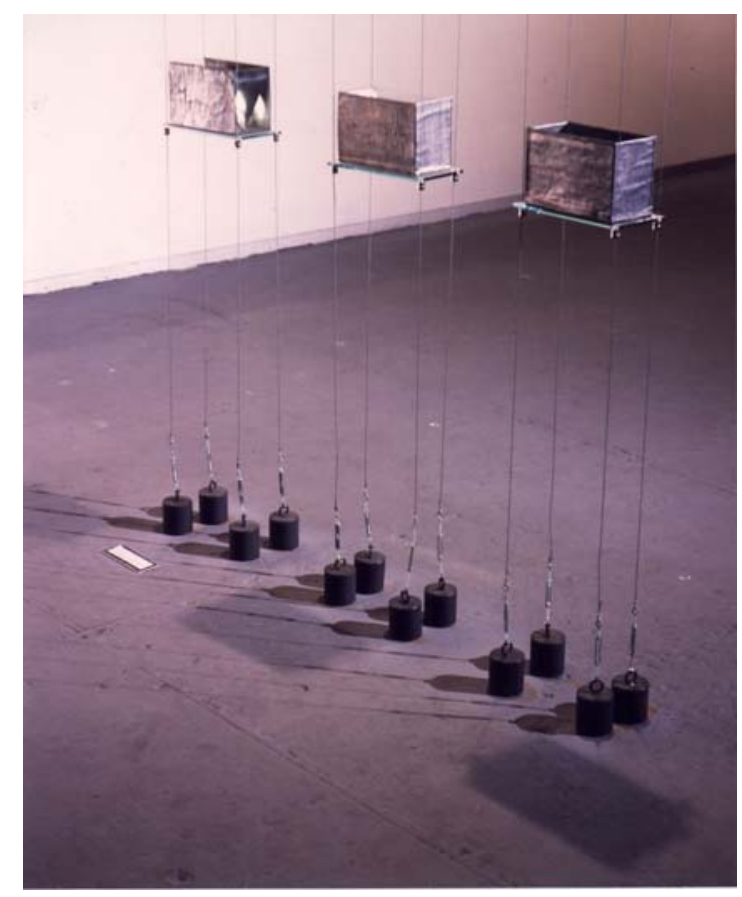

Juntamente com o conjunto de pequenos aquários existe uma grande escultura no mesmo formato dos pequenos pesos de pesca, feita de vidro e cheia de penas cor de chumbo. Esta escultura é presa a um maço de fios de nylon que atravessam todo o espaço expositivo, em direção ao teto. Embora a referência figurativa seja a mesma encontrada nos pequenos chumbos, a escala nesta escultura é totalmente aumentada, e sua presença faz com que toda a sala da exposição funcione como um grande aquário, incluindo os espectadores e o entorno do trabalho. As contradições voltam a atuar aqui, não se sabendo se estamos dentro ou fora do trabalho, se somos pequenos ou grandes perante ele.

Procurei constituir uma rede de paradoxos (leveza/peso, grande/pequeno, opacidade/transparência, luz/escuridão) que confunde a percepção do observador, oferecendo-lhe possibilidades de fruição menos narrativas e mais fenomenológicas. O título abstrato e poético, "Fossem os vazios mais leves", apenas sugere sensações metafóricas, entretanto sem acrescentar maiores esclarecimentos à obra. A água tem aqui uma função de dubiedade, turvando e distorcendo a percepção e guardando para si um certo mistério.
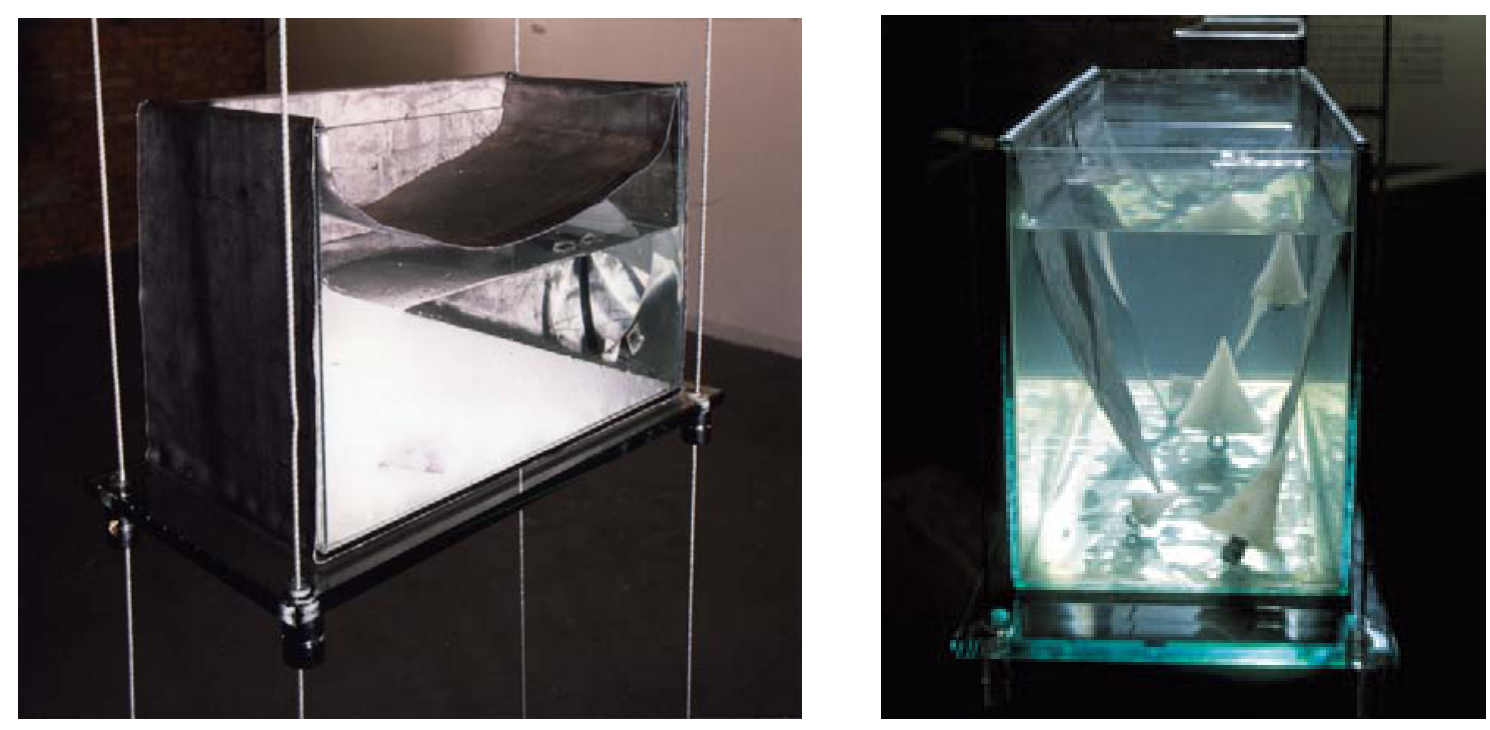

Hugo Fortes. Fossem os vazios mais leves. (Detalhes) 2000.Instalação: vidro, água, parafina, chumbo, lentes de aumento. Dimensões variadas. 


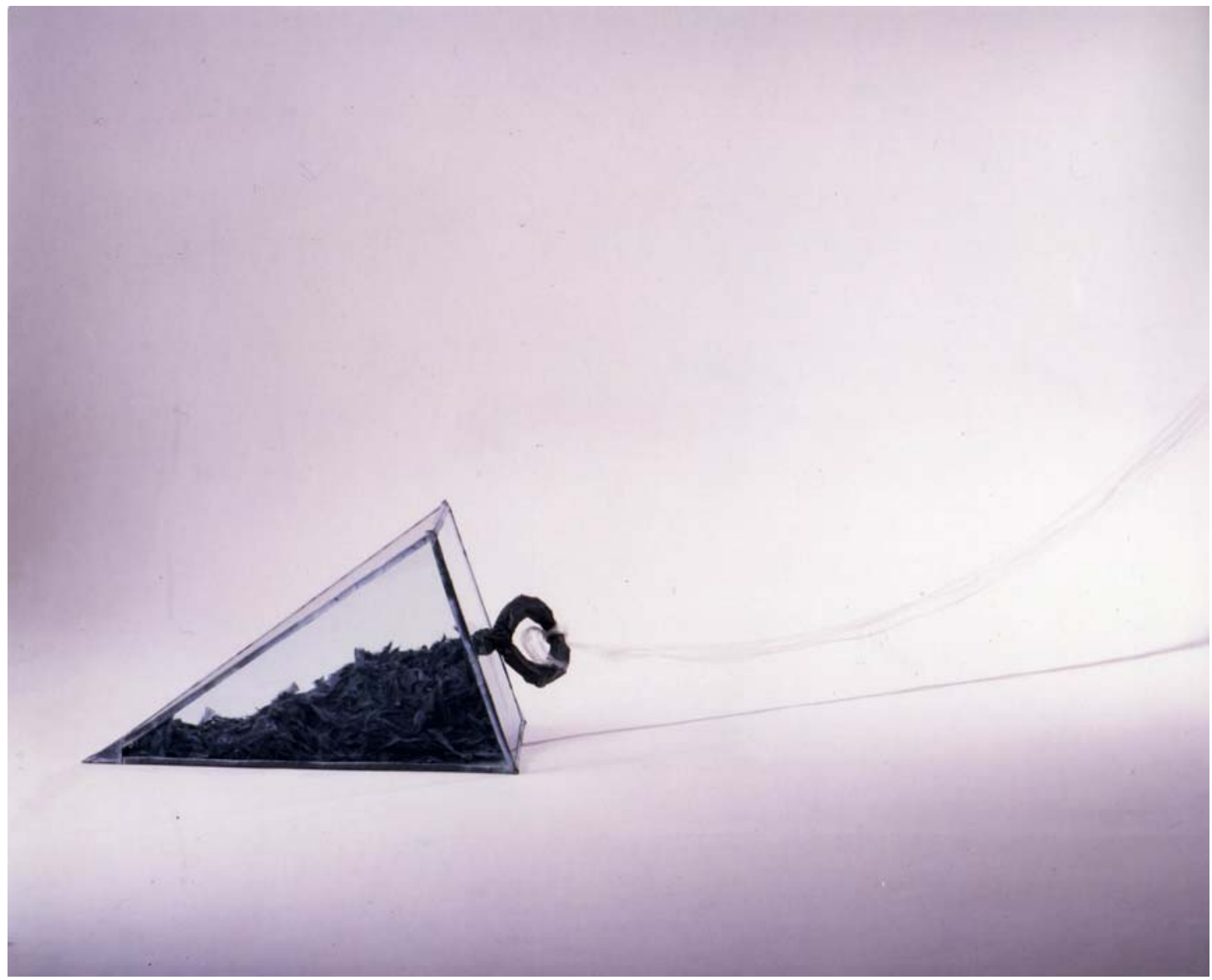

Hugo Fortes. Fossem os vazios mais leves. (Detalhe) 2000. Instalação: vidro, chumbo, penas e nylon. Esta peça: 180 x $80 \times 80 \mathrm{~cm}$. SESC Pompéia. São Paulo. 
Provavelmente a série mais importante de trabalhos do início de minha produção foram os aquários criados a partir do ano 2000 , logo após a realização da instalação "Fossem os vazios mais leves". O desenvolvimento destes trabalhos serviu-me para a criação de um vocabulário plástico pessoal e para a investigação das possibilidades expressivas e formais de determinados materiais e processos escolhidos, que passaram a aparecer com freqüência em minha produção posterior.

Pensados como esculturas individuais, estes trabalhos, muitas vezes, sugerem paisagens orgânicas e mutantes. Neles procurei utilizar a água e suas propriedades físicas e ópticas (refração, reflexão, densidade e flutuação) de maneira escultórica, conjugando-a com outros materiais como parafina, chumbo, argila, imagens etc. A presença de materiais e formas orgânicas aliada a sensação de vazio e imaterialidade, que algumas obras propõem, convive com o seu caráter expressivo. As formas das esculturas lembram orgãos ou paisagens geológicas como geleiras e icebergs, que flutuam rodeados pela água que as reflete, amplia e multiplica.

Durante a produção destas obras pude refletir sobre os processos naturais envolvidos na constituição de paisagens, trabalhando com materiais que ora eram eles próprios oriundos da natureza, ora simulavam ou pervertiam as relações naturais. $O$ caráter efêmero dos trabalhos, bem como a atuação dos processos físico-químicos durante o espaço de tempo em que eram expostos, fez-me tomar consciência da transitoriedade da vida e da arte. As paisagens aqui apresentadas, não se tratam de representações miméticas do mundo real, mas propõem realidades possíveis e artificiais, nas quais a natureza é reinventada. Embora encontrem-se reduzidas e acondicionadas em aquários, estas paisagens buscam uma amplidão e uma elevação, e anseiam por uma possibilidade de expressão do sublime, ainda que remota. $O$ conceito de Sublime norteou a produção de artistas românticos, como William Turner e Caspar David Friedrich, que viam na natureza grandiosa e desafiadora uma força quase sobrenatural. É quase impossível na 
sociedade urbana contemporânea entrar em contato com a potência das forças naturais como queriam os românticos; vivemos longe demais das grandes geleiras e despenhadeiros ou das matas míticas, se é que elas ainda existem. Porém não perdemos ainda a capacidade de imaginá-las ou desejá-las.

Quando insisto em repensar o sublime ao ver e criar estes trabalhos, não parto de uma atitude ingênua, de simples resgate romântico. Reconheço as dificuldades da busca de transcendência na contemporaneidade. Porém a própria idéia de sublime contém em si algo de inatingível e irrealizável. Não é apenas na força incontrolável da geleira ou da tempestade que reside a idéia do sublime, mas também na sensação de impotência e pequenez do homem que as contempla. As paisagens que cultivo em meus aquários não atingem as mesmas dimensões dos grandes acidentes naturais; elas permanecem à primeira vista contidas nos limites que a sociedade urbana contemporânea as reserva. Mas o observador que quiser enxergá-las através dos reflexos e refrações, sentindo a força de sua flutuação e sua fugacidade poderá talvez intuir algo além das aparências formais, e ansiar por uma necessidade de amplidão, mesmo sem perder de vista os contornos da vida contemporânea.

Creio que a flutuação atinge aqui um papel decisivo na formulação poética de minhas obras. Sua presença assinala metaforicamente um caráter espiritual e metafísico dos corpos que constituem minhas paisagens. Os processos ópticos e físicos que coloco em andamento com a formalização de minhas obras constituem um campo de forças emprestadas do mundo sensível natural, que ao mesmo tempo podem ser observadas em sua imanência fenomenológica ou interpretadas como energias passíveis de transcendência.

Não é necessário que o espectador compartilhe das mesmas opiniões que eu ao observar meus aquários. Basta que ele se interesse por eles e possa descobrir sua própria forma de fruição dos trabalhos. Não me furto porém à liberdade de poder tecer minhas próprias conjecturas sobre eles ou de tomar consciência do que informa a constituição de minha poética. 


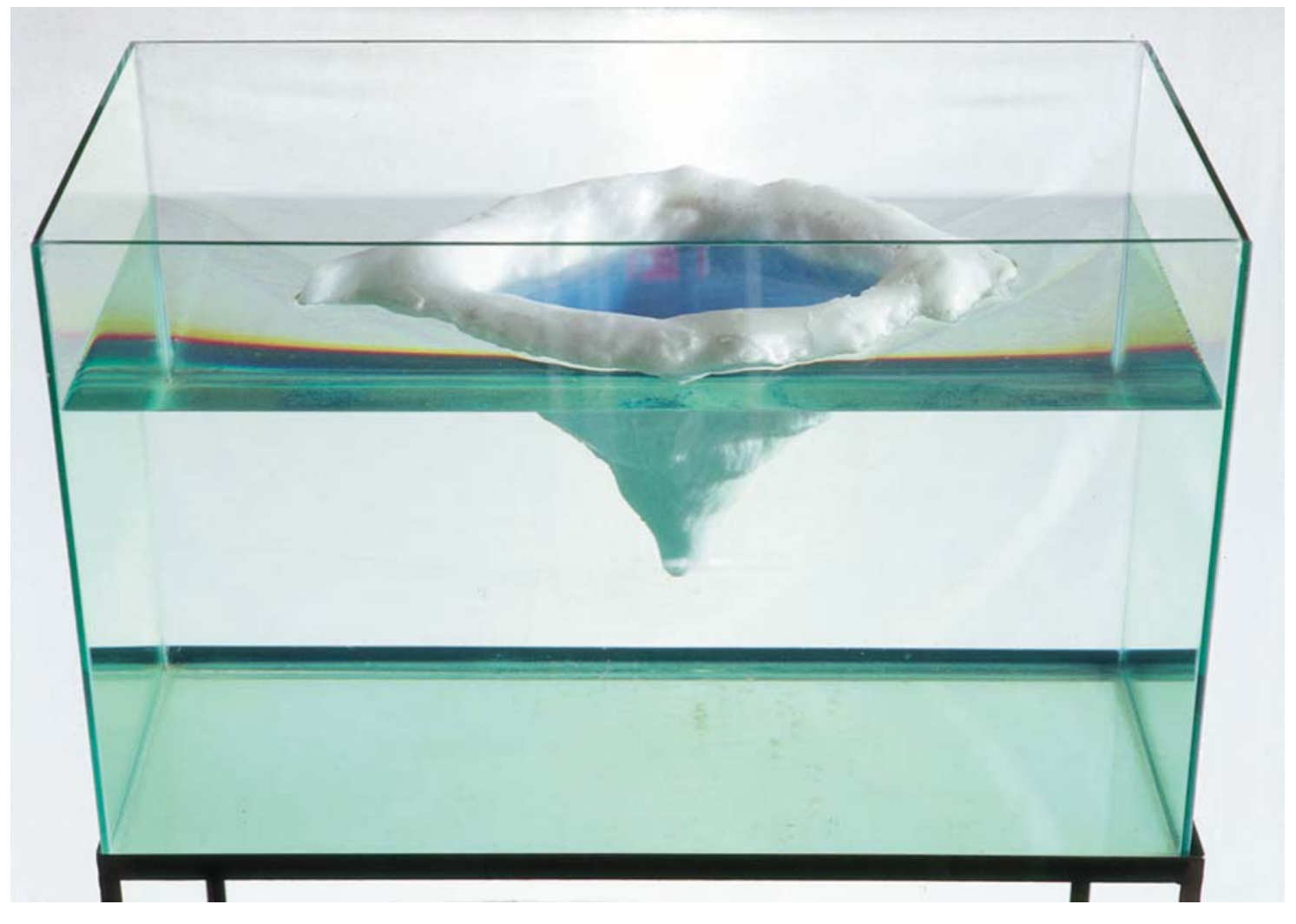


Hugo Fortes. Sem título. 2001. Vidro, água, parafina e pigmento. 80 × 50 × $40 \mathrm{~cm}$. Coleção João Carlos Figueiredo Ferraz 


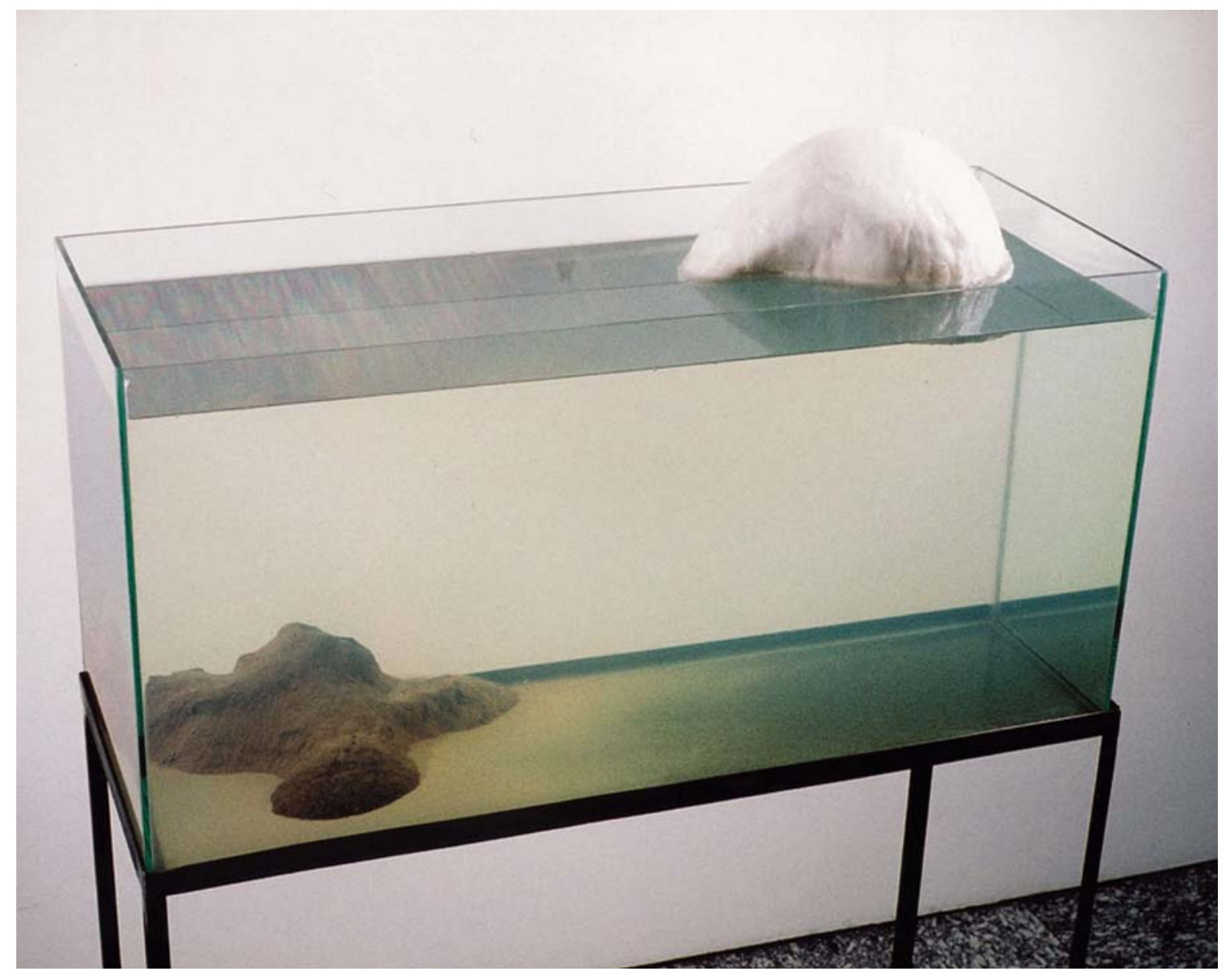

Hugo Fortes. Sem título. 2001. Vidro, água, parafina e argila. 80 × 40 × $30 \mathrm{~cm}$ 


\subsection{Flutuação e vôo entre a natureza e a cultura}

A flutuação é um conceito que atravessa todo o meu fazer artístico, desde estes aquários iniciais até mesmo em minhas instalações mais recentes, como o trabalho "Libélulas" apresentado em Berlim em 2004 ou a instalação "Molhar Molière" apresentada em 2005 em Paris.

Se na série de aquários e no trabalho "Fossem os vazios mais leves" a flutuação manifestava-se no boiar de peças de parafina no meio líquido, nos trabalhos "Libélulas" e "Molhar Molière", ela alça vôo e passa a ocupar o espaço aéreo da sala.

$\mathrm{Na}$ instalação "Libélulas", pesos de chumbo foram presos através de fios de cobre às paredes da sala, traçando desenhos aéreos no espaço, que se assemelhavam a asas de libélulas (ver fotos da página seguinte). Estas enormes asas apenas se delineavam pelo espaço através dos fios de cobre. O espectador tinha que se mover com cuidado no espaço expositivo, que embora extremamente leve visualmente e pouco ocupado pela matéria, era entrecortado por fios quase invisíveis. A noção de desenho espacial foi-me bastante importante para a realização deste trabalho, no qual as linhas ganham corpo tridimensional e interferem na circulação dos visitantes.
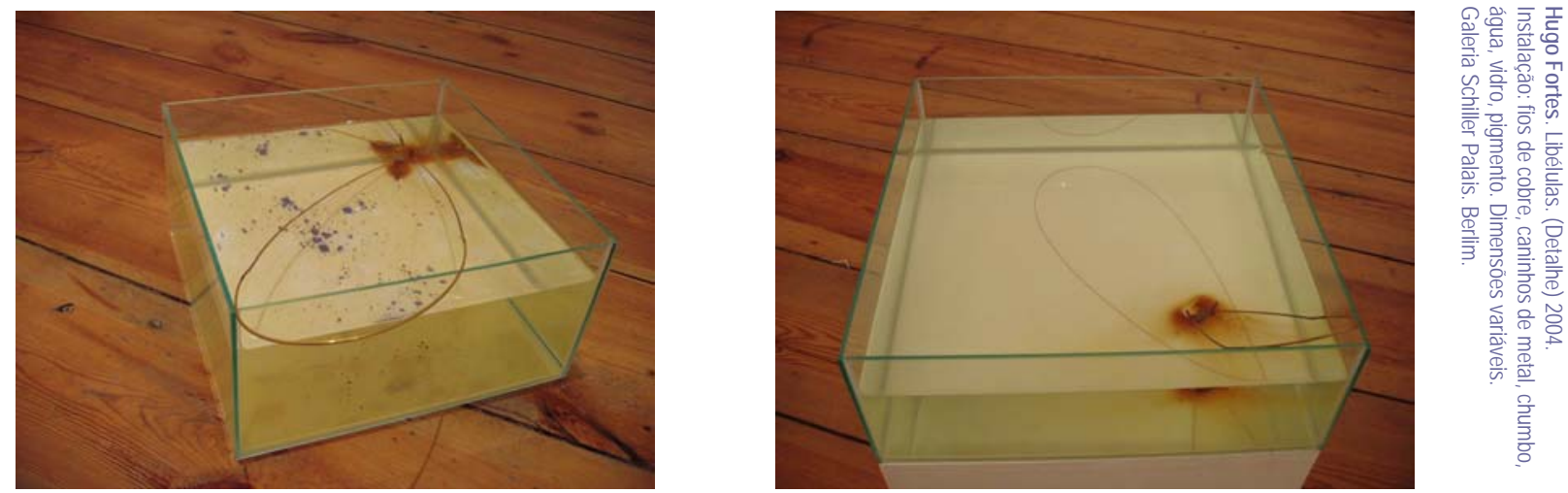

As „libélulas" sobrevoavam aquários quase a tocar a água, às vezes chegando a mergulhar, oxidando-se e refletindo-se. $\mathrm{O}$ trabalho procurou captar a delicadeza do vôo das libélulas e o sutil momento em que este inseto passa de raspão sobre a água em sua dança de acasalamento. Fragilidade e leveza dão a tônica do trabalho. 


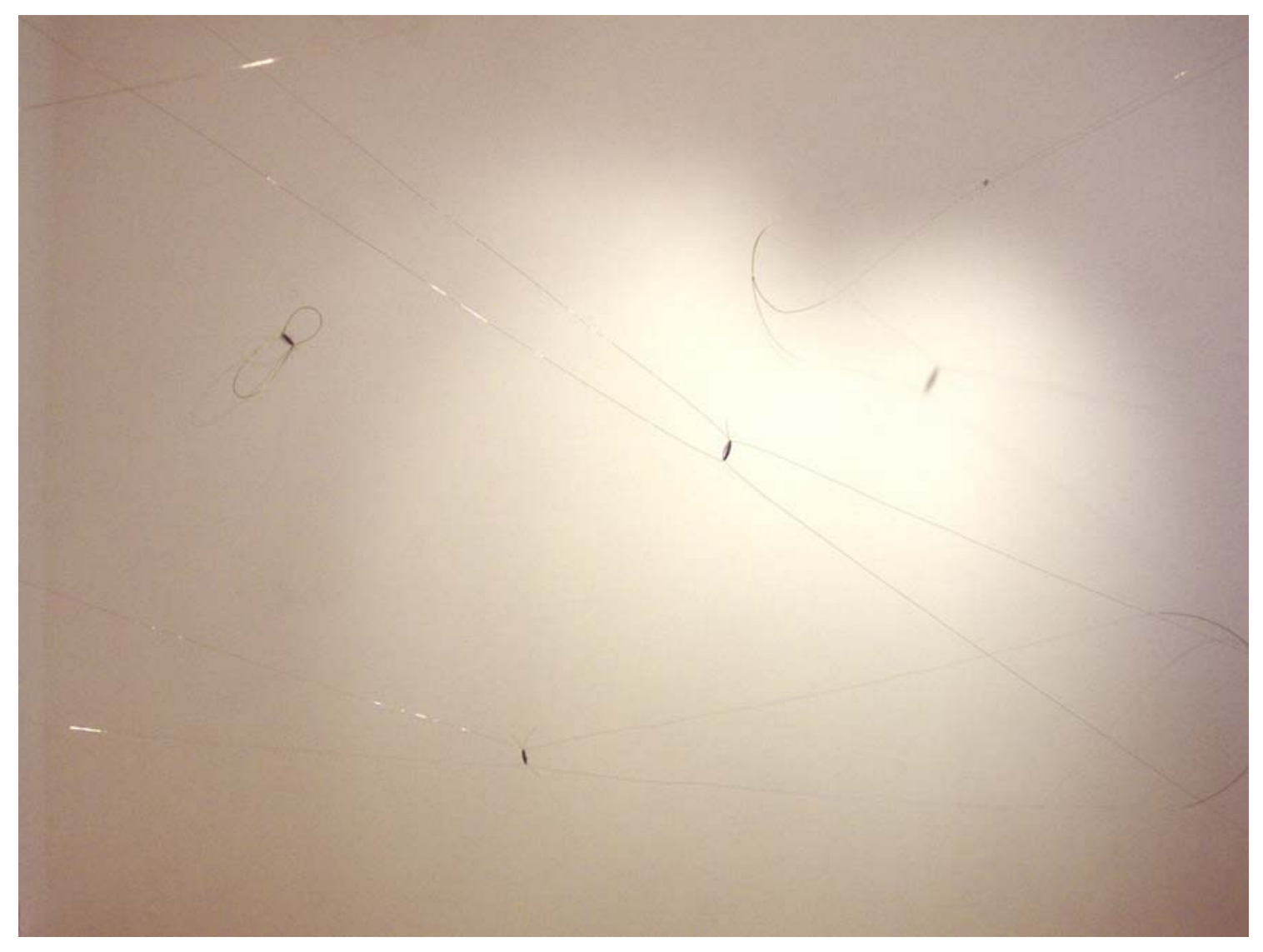




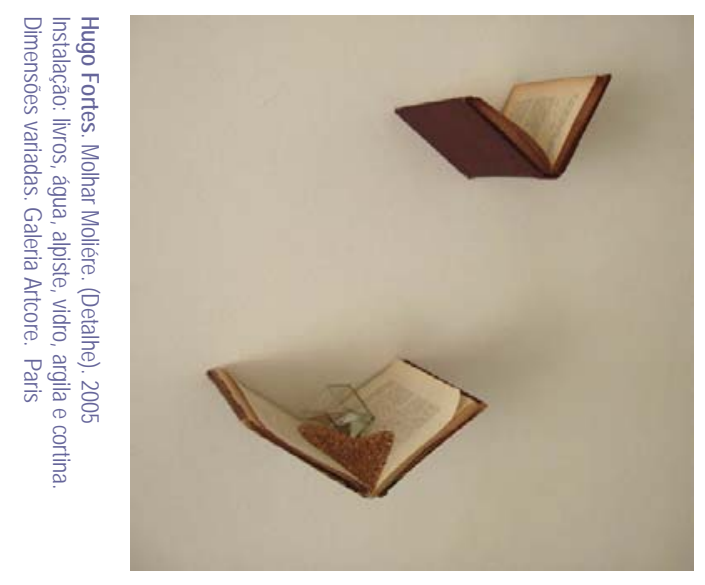

Flutuação e vôo também podem ser vistos na instalação "Molhar Molière". A instalação foi concebida como um site-specific para um prédio onde viveu e morreu o dramaturgo Molière. Procurei criar uma instalação composta por várias peças diferentes que se distribuíam no espaço da sala.

O trabalho reuniu por um lado elementos que remetiam à cultura e à civilização, como livros antigos em várias línguas e uma cortina esvoaçante, e por outro lado elementos do mundo natural, como água, argila e comida para pássaros. Os artefatos culturais mesclavam-se com a natureza, sendo incorporados como matéria por ela, tornando-se suscetíveis a seus processos de transformação.

Em uma das janelas da sala foram colocados aquários do lado de fora do prédio, que continham livros antigos mergulhados em água. No interior da sala havia também outros aquários com livros, ou livros cobertos com alpiste e argila que pareciam flutuar na parede.

Os livros escolhidos eram oriundos das áreas mais variadas do conhecimento, desde a literatura, até a filosofia, a agronomia ou a matemática. Os livros, como bens culturais que tentam descrever o mundo e materializar o conhecimento humano sobre a natureza que o cerca, tornaram-se aqui matéria fugaz e perecível.

Os aquários colocados na parte externa da janela do prédio produziam arco-íris no interior da sala, conforme os raios solares eram filtrados pela água. Sobre as tampas de vidro deste aquários, havia também alpiste e os pássaros podiam vir se alimentar no trabalho. (ver figuras páginas seguintes)

A atmosfera esvoaçante sugerida pelos pássaros e pelo flutuar do livros ganhava um aspecto quase fantasmagórico pela introdução de uma longa cortina translúcida que atravessava o espaço e mergulhava em um caixa de vidro com água e argila.
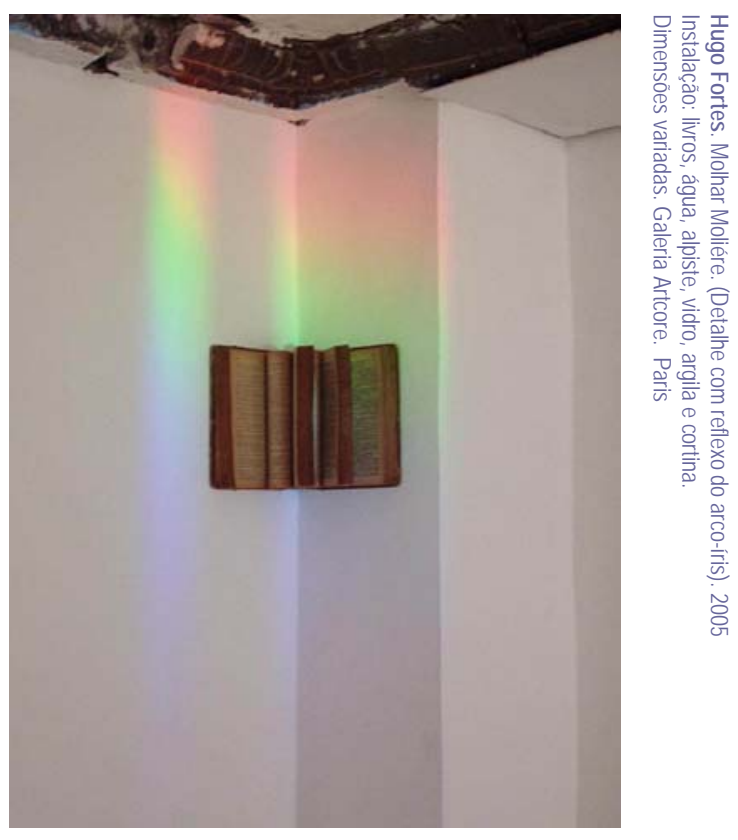

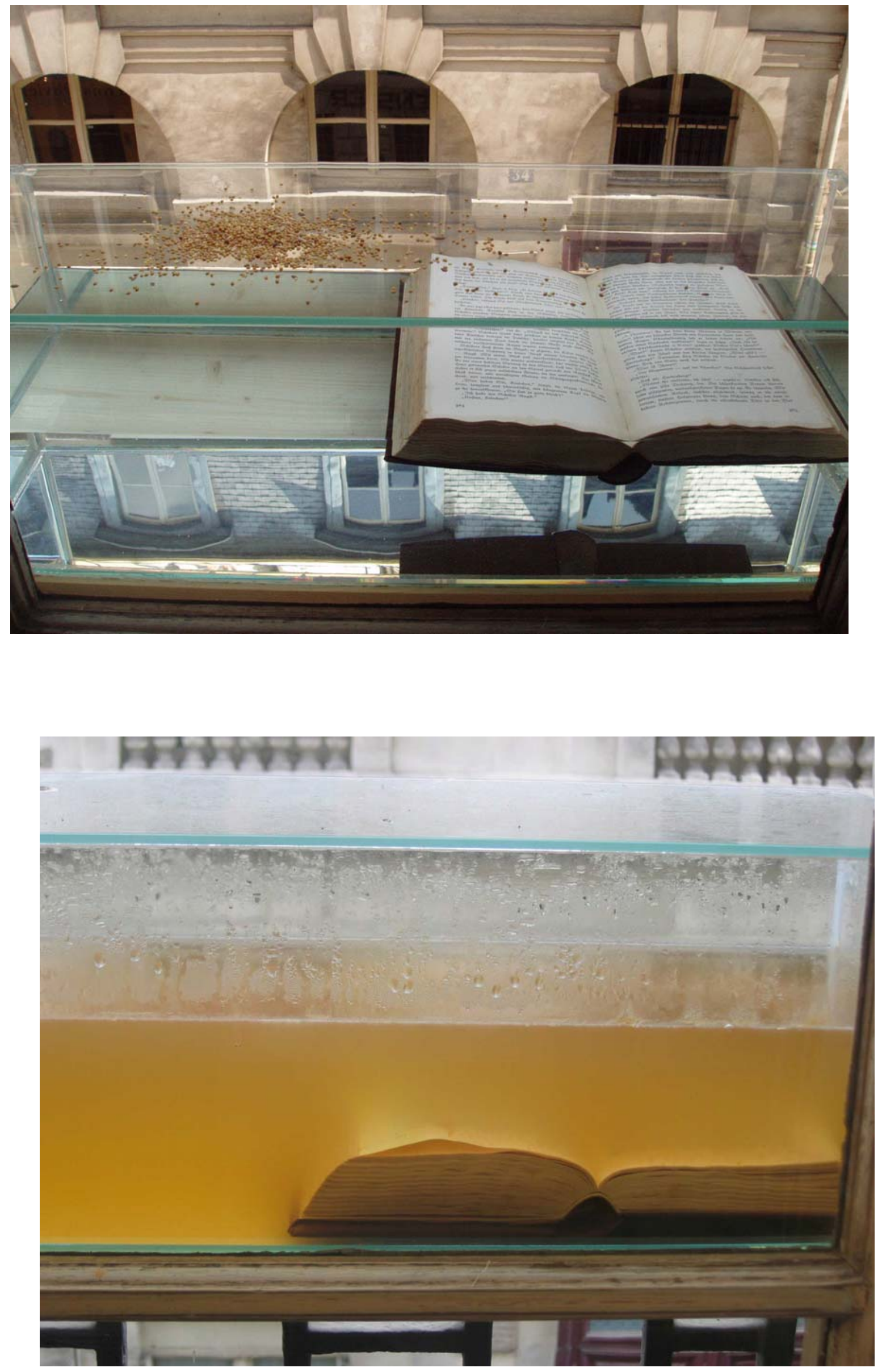


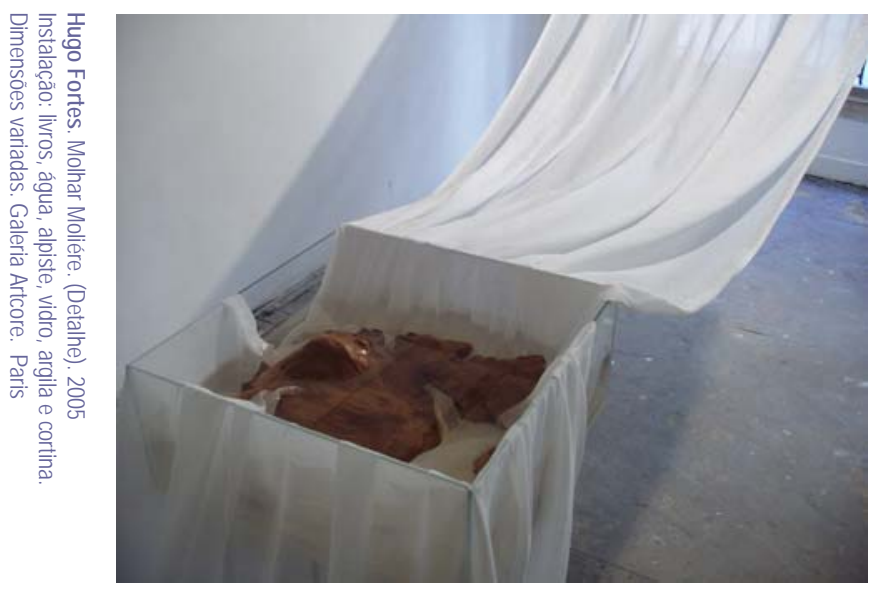

desenvolvidos no meio aquático.

A cortina, como tradicional elemento da decoração e da cultura européia, em especial a francesa, é ao mesmo tempo um elemento teatral, que nos faz lembrar de Molière. Ao mergulhar na água do aquário e ser coberta por montes de argila, a cortina perde seu caráter imponente e soberano, e passa a sofrer a corrosão do tempo e estar sujeita as contaminações dos processos naturais

O trabalho "Molhar Moliére" lida de certa forma com o espírito do lugar e seus fantasmas. Ele instala-se em um ambiente impregnado de história, testemunha da deterioração do tempo e dialoga com o passado. Enquanto o tempo teima em fluir e transformar as matérias e os homens, a arte instala-se como um momento de suspensão e desaceleramento, que convida à reflexão e a visualização quase imaterial do pensamento. Flutuar ou voar são na gíria da linguagem comum sinônimos para os devaneios. Nos trabalhos até aqui apresentados, estes processos não ocorrem apenas no mundo metafórico das idéias, mas constituem os próprios processos físicos que animam e atuam sobre o mundo sensível.

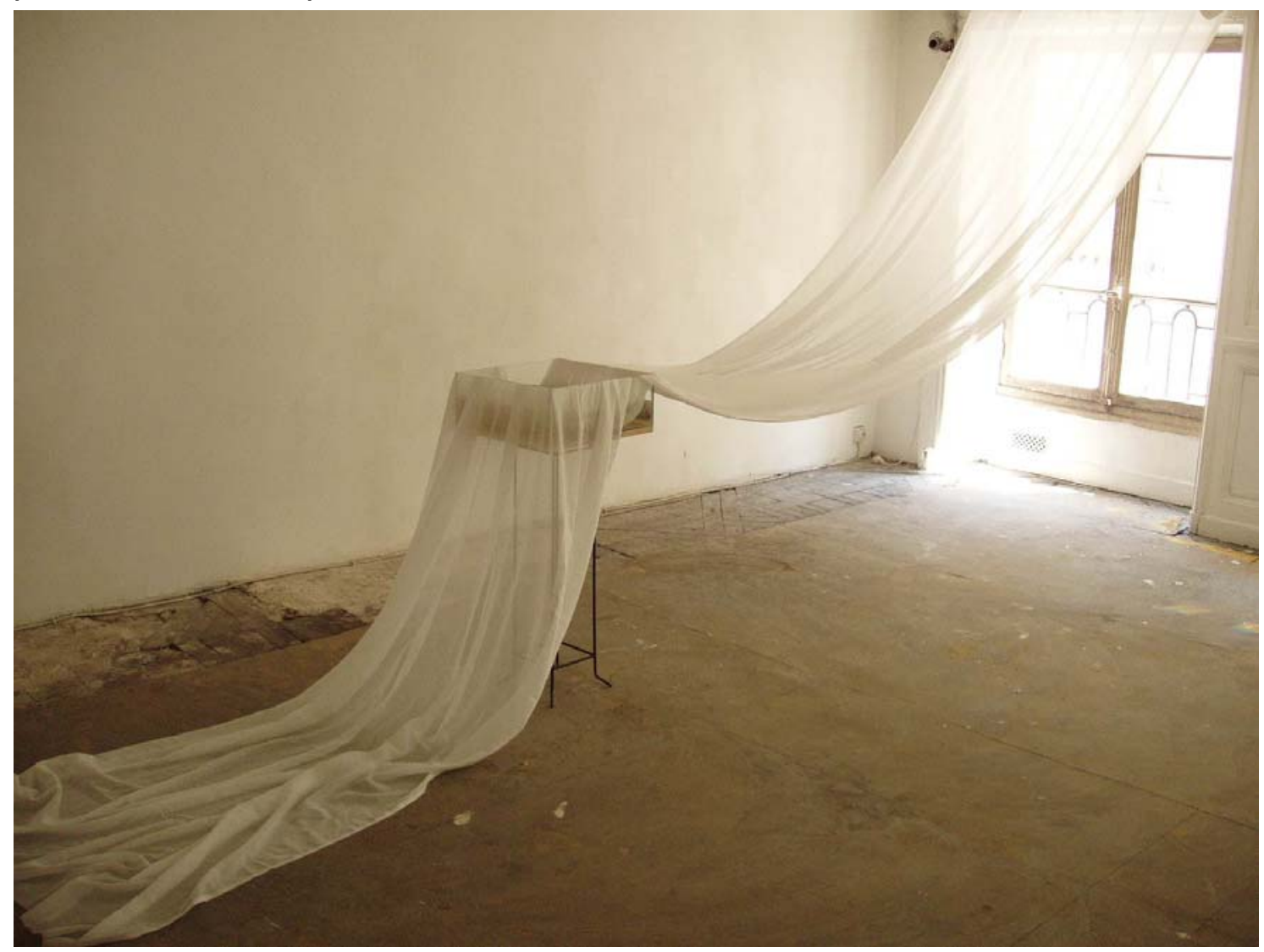

Hugo Fortes. Molhar Moliére. (Detalhe). 2005. Instalação: livros, água, alpiste, vidro, argila e cortina. Dimensões variadas. Galeria Artcore. Paris 


\subsection{Fluxo e refluxo entre passado e presente}

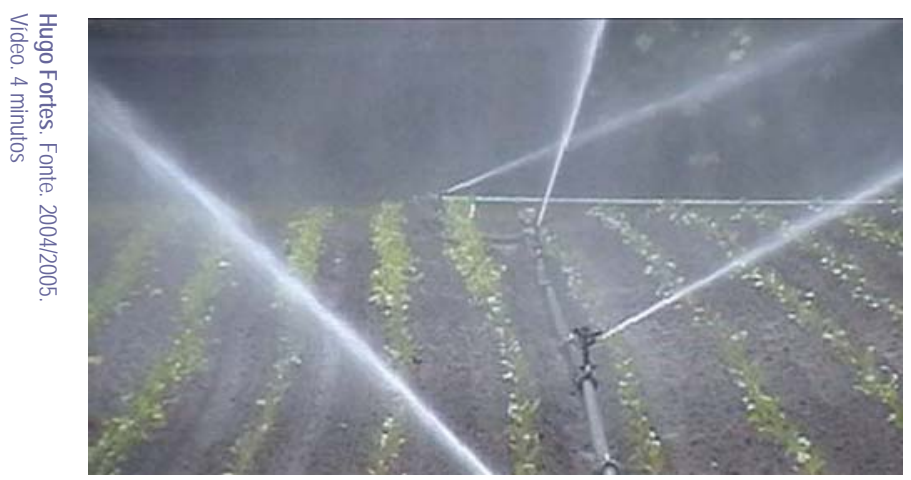

As relações conflituosas entre natureza e cultura estão presentes em meu trabalho não só nas instalações, mas também em alguns vídeos produzidos entre 2004 e 2006 durante minha estadia na Alemanha. Em pelo menos três deles, a água desempenha um papel importante.

O vídeo "Fonte" retrata uma lavoura européia que é irrigada por Waterspringlers automáticos. A água aqui não se apresenta em sua fluidez ou repouso natural, mas é esguichada mecanicamente, traçando movimentados desenhos geométricos de luz no espaço. A artificialidade da produção agrícola e o cerceamento da natureza pelo homem contemporâneo são evidenciados pelo movimento maquínico dos jatos d'água e pelo som metálico e repetitivo do aparato técnico que os produz.

Enquanto o vídeo "Fonte" exibe as condições da paisagem natural do presente, o vídeo "Ophelia" problematiza referências da arte do passado procurando reencenála no ambiente contemporâneo. Este vídeo mostra uma ação realizada por mim, que consistiu da colocação de uma escultura flutuante nas águas do rio Spree em Berlim e da filmagem de seu deslocamento. A escultura tinha a forma e o tamanho de um corpo feminino, representando a personagem Ophelia, da peça Hamlet de Shakespeare, que tantas vezes foi tema da pintura dos séculos XVIII e XIX, como no famoso quadro de Sir John Everett Millais.

Ophelia é uma personagem dramática e poética, que morre afogada enquanto declama versos enlouquecida de amor. Sua idealização romântica como vítima e heroína que se entrega apaixonadamente às águas, misturando-se a natureza é questionada ao ser lançada num rio urbano contemporâneo, no qual trafegam lanchas apressadas em direção à cidade. Seu corpo é quase detrito, que flutua engessado e fugaz, como um fantasma que reclama um sentimentalismo que já não encontra mais lugar no presente. 


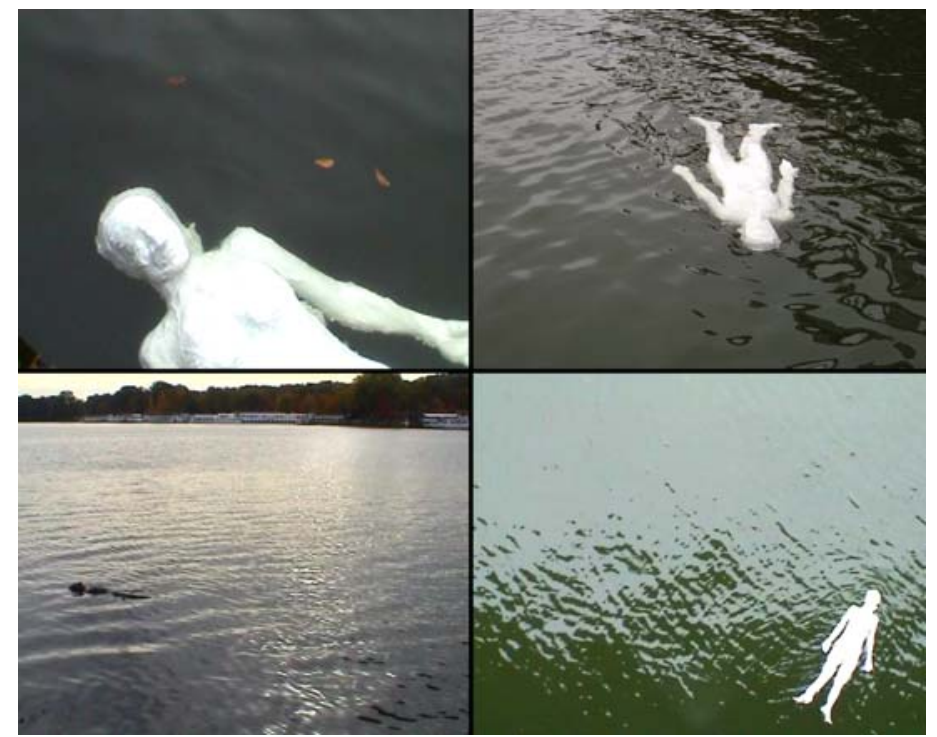

Vivemos em uma sociedade em que não se permitem mais devaneios românticos e na qual a natureza parece não mais encarnar um poder espiritual. A prepotência do homem contemporâneo, que tudo acredita dominar e conhecer cientificamente, nos impulsiona a uma busca cada vez mais acelerada do futuro, nos impedindo de parar um momento para lançar dúvidas. Daí talvez o meu interesse em alguns trabalhos pelos temas do passado.Não para recuperá-los em uma atitude saudosista, mas para colocá-los em atrito com o presente e problematizá-los.

Isto ocorre também em meu vídeo "Eclipses", no qual utilizo e revisito as metáforas já gastas, porém sempre poéticas, dos cisnes e da lua. Em um filme totalmente gravado à noite, cisnes deslizam pela água, misturando-se a lua, em uma atmosfera de sonho que é reforçada pelo canto lírico de um poema de Paul Valèry sobre a música Clair de Lune de Claude Debussy. O filme pode soar de certa forma anacrônico nos tempos de hoje, porém sua atualidade se dá tanto pelos recursos técnicos do meio eletrônico em que ele foi realizado, como pelas circunstâncias específicas da época em que ele foi filmado. O derradeiro "canto dos cisnes" que à primeira vista possa talvez parecer apenas um delírio romântico e metafórico, ganha uma nova interpretação quando se sabe que o filme foi produzido em uma época em que a gripe aviária dizimou efetivamente centenas de pássaros. A reflexão sobre a fugacidade da vida não é portanto exclusividade romântica - ainda é possível e necessária, mesmo que a arte atual e a sociedade contemporânea lhe reservem pouco espaço.

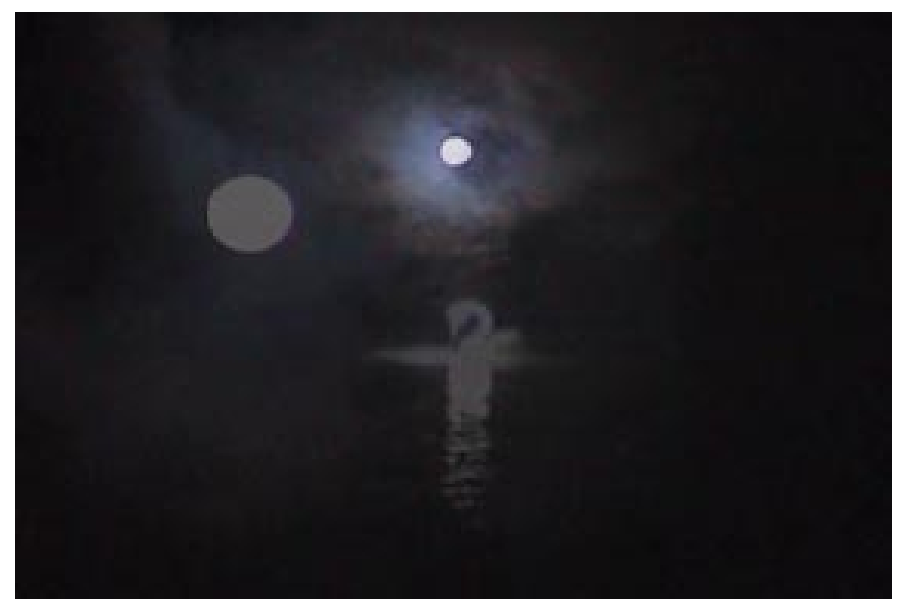




\subsection{Os olhos cheios d'água}

Se o passado da arte ecoa em algumas de minhas obras, com um sentimentalismo consciente, o mesmo ocorre com minhas memórias pessoais. Se me interesso pela paisagem em grande parte de minha obra, é por ter aprendido a olhá-la desde cedo.

Lembro-me de tardes da infância, em que nós, crianças, primos e primas, amigos, espalhávamos nossos cavaletes pelos quintais, para que após a chuva pudéssemos tentar pintar "do natural" as roseiras ou jabuticabeiras que víamos. Ou então procurávamos copiar pequenos cartões, reproduções gastas de paisagens pintadas por grandes artistas, para as quais não havia lugar em nossa pequena cidade de interior. Havia porém outras coisas para se olhar por ali também - como os imensos olhos azuis translúcidos de Tia Maria. Como única detentora dos dons da pintura na família, e idosa caçula entre as três solteiras tias-avós-marias, era Maria do Carmo a encarregada de ensinar a ver para todas as gerações da criançada. Ou de pelo menos corrigir suas "artes" e garatujas.

Em sua vida pacata e quase monástica, Tia Maria não se casou, não fez longas viagens, não dançou grandes valsas, não precisou de doutorado, nem gostava muito de Picasso. Mesmo em sua vida recolhida, Tia Maria encontrou em sua arte caseira e delicada sua própria maneira de enxergar o mundo. E abriu os olhos de muitos...

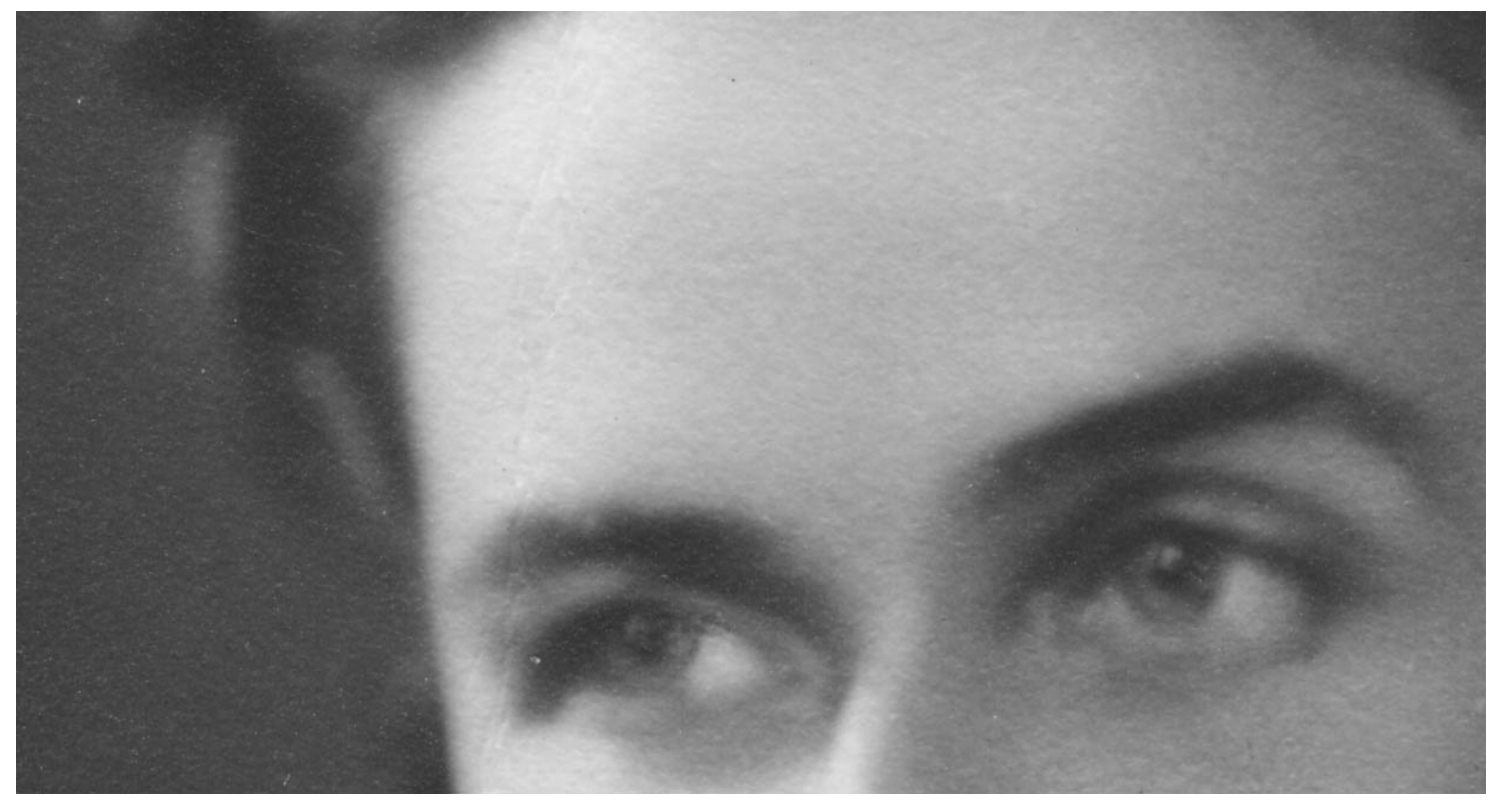


Inspirado por essa memória afetiva, realizei em 2003 o trabalho "Os olhos de Tia Maria", quando minha querida personagem verídica contava com 94 anos. O trabalho pretende seduzir visualmente o espectador, mostrando-lhe o aspecto cristalino e úmido dos olhos, por onde passa a luz para construir as imagens e também por onde fluem as lágrimas. O trabalho fala sobre a possibilidade de ver e a beleza da visão e dos olhos. Afinal, não seriam os olhos os receptores e transmissores por excelência do pensamento visual e da beleza da arte?

O trabalho "Os olhos de Tia Maria" consiste de uma instalação composta de peças de vidro, parafina, pigmento e água em formas côncavas e convexas apoiadas sobre o chão, ou afixadas na parede. Através deste jogo de esculturas busca-se novamente evocar questões relativas à transparência e leveza, porém neste caso a forma circular dos recipientes, realizada em vidro soprado ou moldada em parafina, faz uma referência poética aos olhos, funcionando como uma metáfora sobre o ver. A cor azul, presente nos líquidos e nos pigmentos em pó que tingem as parafinas, confere uma atmosfera de cosmos ao trabalho. A instalação inclui também um texto poético aplicado sobre um vidro circular que se apoia em um monte de cal e pigmento azul. O espectador circula pelo trabalho, vendo-o e "sendo visto" por ele.

Cada peça aqui é como um receptáculo para o olhar, um local para pousar a visão e mergulhar em seu próprio interior. O olhar sempre foi um tema caro aos artistas e aos filósofos. A concepção dos olhos como "janelas da alma" atravessa os tempos e a cultura. A analogia entre o corpo do homem e o corpo da terra produziu inúmeros exemplos no decorrer da história da arte, estando presente até nos escritos de Leonardo da Vinci. A expressão "olho d'água", ainda em uso na língua portuguesa, é um reflexo destas concepções. Os lagos seriam os olhos da terra, assim como as pedras, seus ossos e os rios, suas veias. É possível observar esta analogia também no trabalho "Os olhos de Tia Maria". Os olhos aqui retratados são ao mesmo tempo lagos, luas ou astros que vagam no espaço azulado. Isto torna-se ainda mais claro quando se observam as fotografias que se originaram a partir de detalhes deste trabalho (vide item 4.7).

O olhar é fonte de diversas dúvidas filósoficas que dividiram pensadores. O olho é ora entendido como um aparelho neutro que simplesmente recebe as imagens do mundo e as processa, ora é tido como um orgão pensante, que seleciona conscientemente aquilo que vê. No texto "O olhar", Alfredo Bosi apresenta uma síntese das mais diferentes posições epistemológicas a respeito do olhar. Bosi destaca ainda a função de conhecimento da visão. Para este autor, "conhecer é estar imerso em um oceano de partículas cintilantes e nele engolfar-se sensualmente. Conhecer é ser invadido e habitado pelas imagens errantes de um cosmos luminoso." 27 
O conhecimento do mundo não se dá portanto puramente através da razão, mas sobretudo pela experiência sensorial, na qual a visão desempenha papel fundamental. Conhecer o mundo pelos olhos e dá-lo a ver aos olhos dos outros é a função do artista. Por mais que o artista contemporâneo busque uma conceituação intelectualizada, e por vezes até negue o puro e simples prazer da observação visual ao espectador, a arte não se descola totalmente de sua origem visual e da vontade de buscar a beleza. A crescente intelectualização da arte, de um lado estimula a discussão filosófica sobre a obra artística; por outro lado, porém, tende a criar dogmas, como o da impossibilidade da discussão do Belo na contemporaneidade ou o da negação da origem emocional da arte.

O trabalho "Os olhos de Tia Maria" representa uma tomada de posição perante este dogmatismo. Procuro a partir de referências à história afetiva pessoal valorizar ao mesmo tempo a simplicidade e a profundidade do fazer artístico, e recolocar a questão do Belo e do prazer do olhar no universo contemporâneo.

Não é apenas minha memória sentimental que está em jogo nesta obra, mas uma vontade de tocar naquilo que constitui a essência da arte. Afinal, a obra está aí para ser vista...

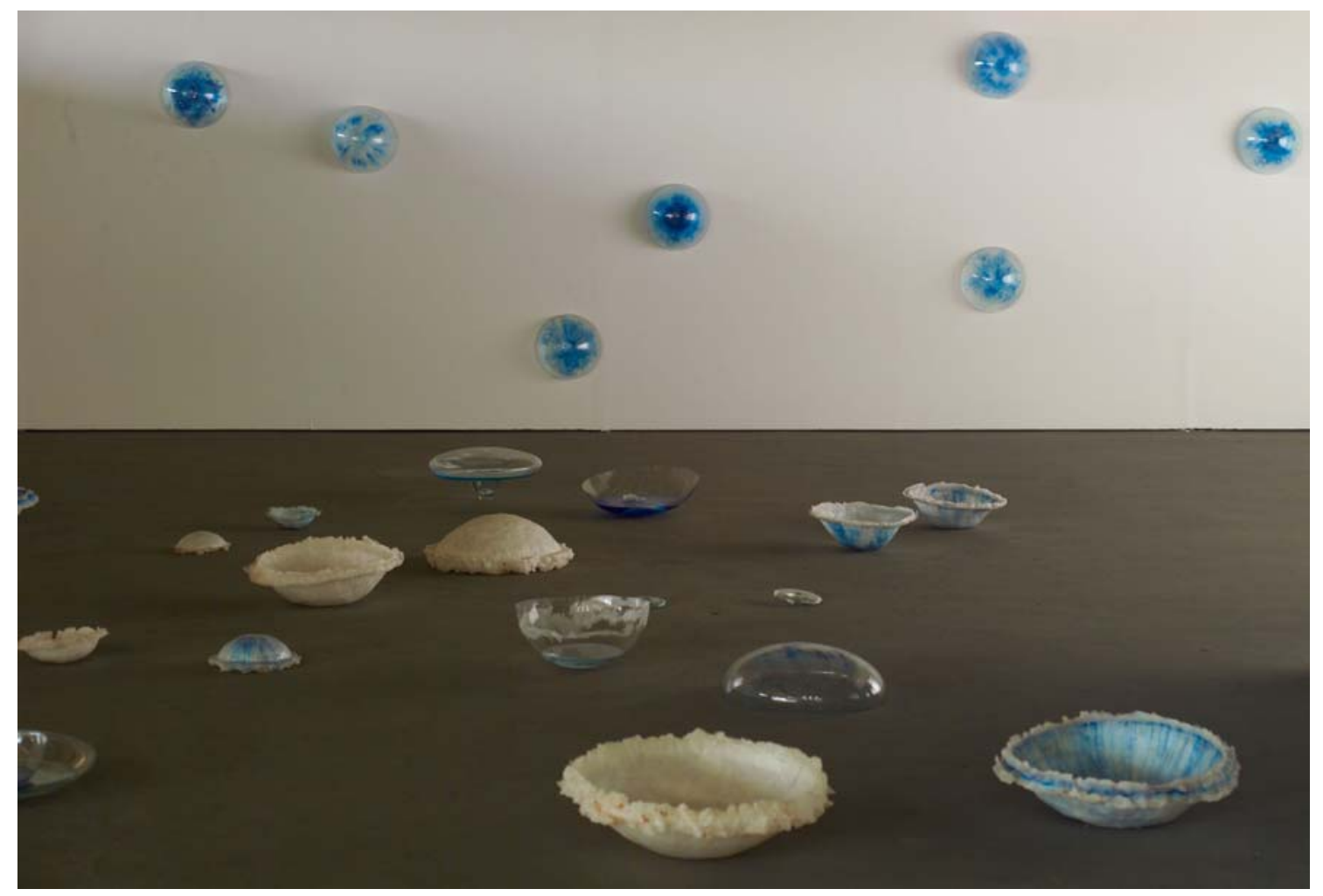

Hugo Fortes. Os olhos de Tia Maria. 2003. Instalação: vidro, água, parafina, pigmento e texto 


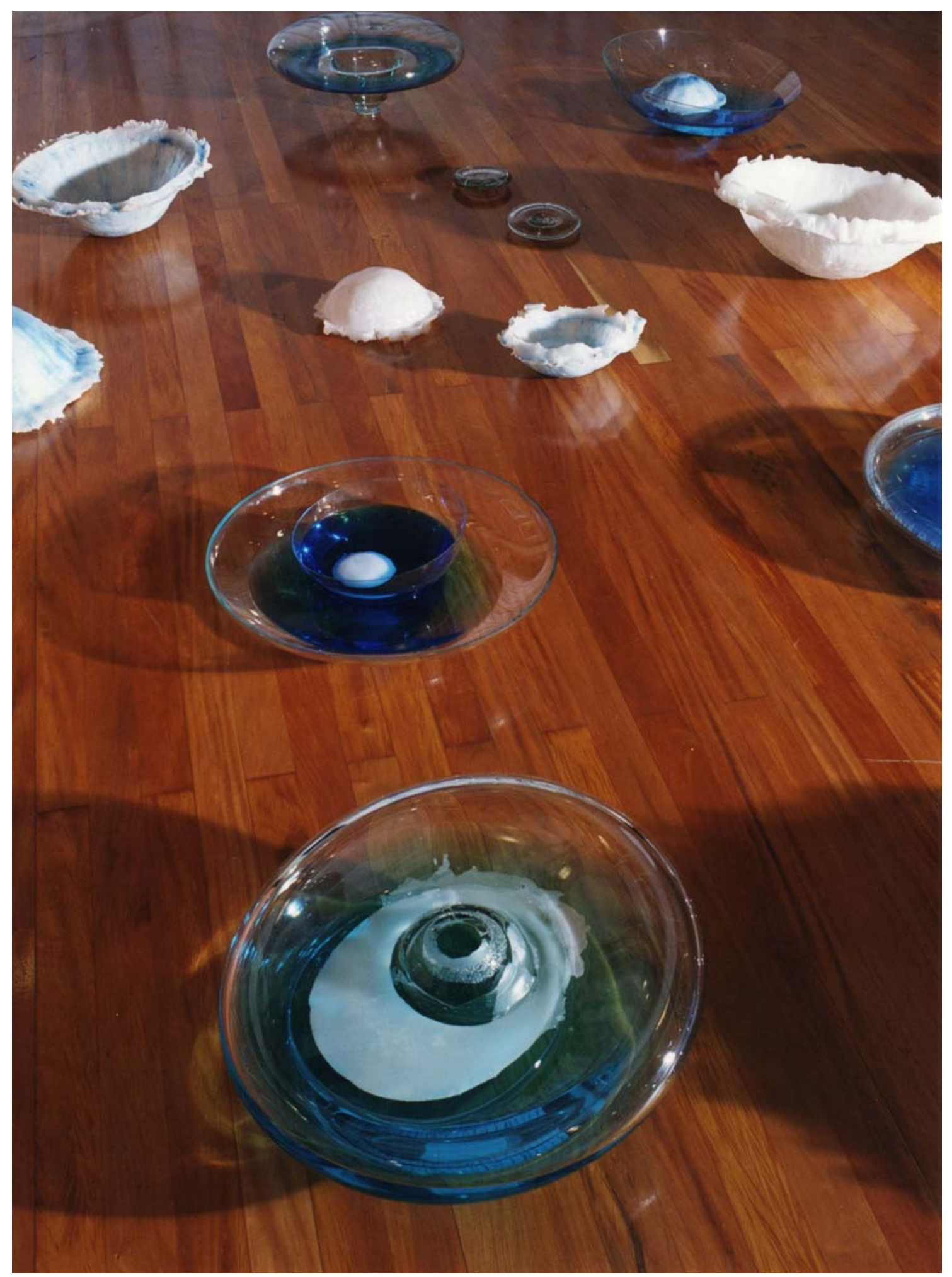

Hugo Fortes. Os olhos de Tia Maria. 2003. Instalação: vidro, água, parafina, pigmento e texto 


\subsection{Os reflexos e as imagens}

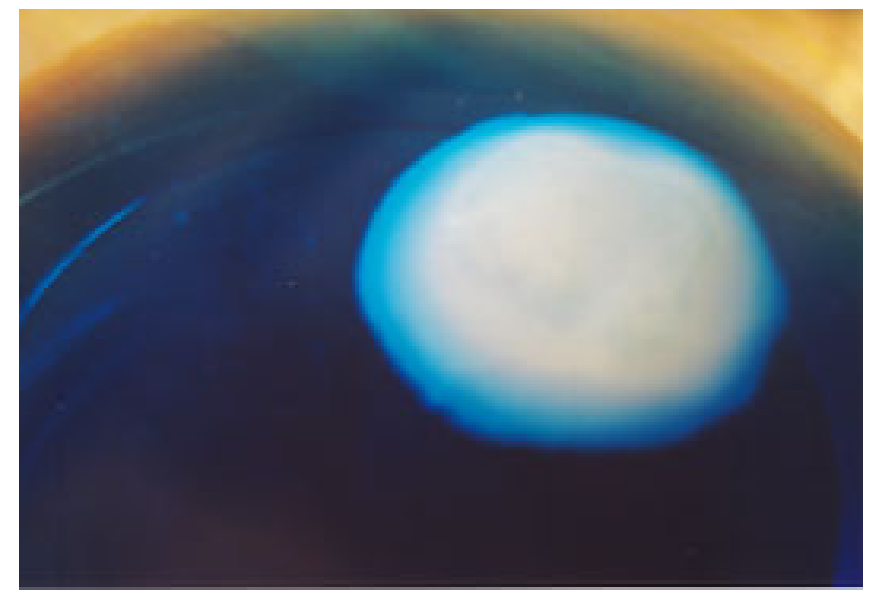

Mesmo que a maior parte de minha obra até agora tenha sido desenvolvida no campo tridimensional, sempre tive interesse pelas imagens e pelas superfícies. Meu interesse pela paisagem, gênero por excelência ligado à pintura, bem como minha educação inicial em pintura e o desenvolvimento de meu olhar como fotógrafo, levam-me a dar tanta atenção aos valores plásticos pictóricos, como profundidade e transparência, como a distribuição dos pesos e volumes e as composições da forma.

Quando crio instalações com água e vidro, fascino-me com os reflexos luminosos e jogos ópticos produzidos nos materiais cristalinos. $\mathrm{O}$ aspecto cambiante e incerto dos reflexos me cativa. Para melhor enxergar e dar visibilidade a estas percepções, iniciei, desde o início da produção de meus aquários, um trabalho fotográfico que não apenas os documenta, mas assume uma autonomia plástica ao buscar captar e isolar as imagens fugazes e abstratas que se formam no meio líquido. Ao expor as fotografias ao lado das instalações, não é possível identificar mais referente e referência. Algumas fotografias assemelham-se também a desenhos de carvão sobre papel com formas orgânicas, que realizei antes de iniciar a produção dos aquários. Estes desenhos, não constituem projetos de obra, mas sim imaginário poético autônomo, que permeia minha produção.

Este processo fotográfico tem se realizado durante todo o desenvolvimento de meu trabalho e a fotografia também é muitas vezes reintroduzida em novas instalações, sendo colocada embaixo ou atrás de aquários, refletindo-se, multiplicando-se e distorcendo-se. A imagem funciona assim como um elemento transitório e mutante, ao mesmo tempo fixando uma certa configuração do mundo sensível e posteriormente interagindo e sendo novamente modificada e filtrada por ele. A fotografia é para mim portanto não necessariamente o fim de um processo visual cristalizado, mas uma instância que atualiza uma das virtualidades perceptivas possíveis. 


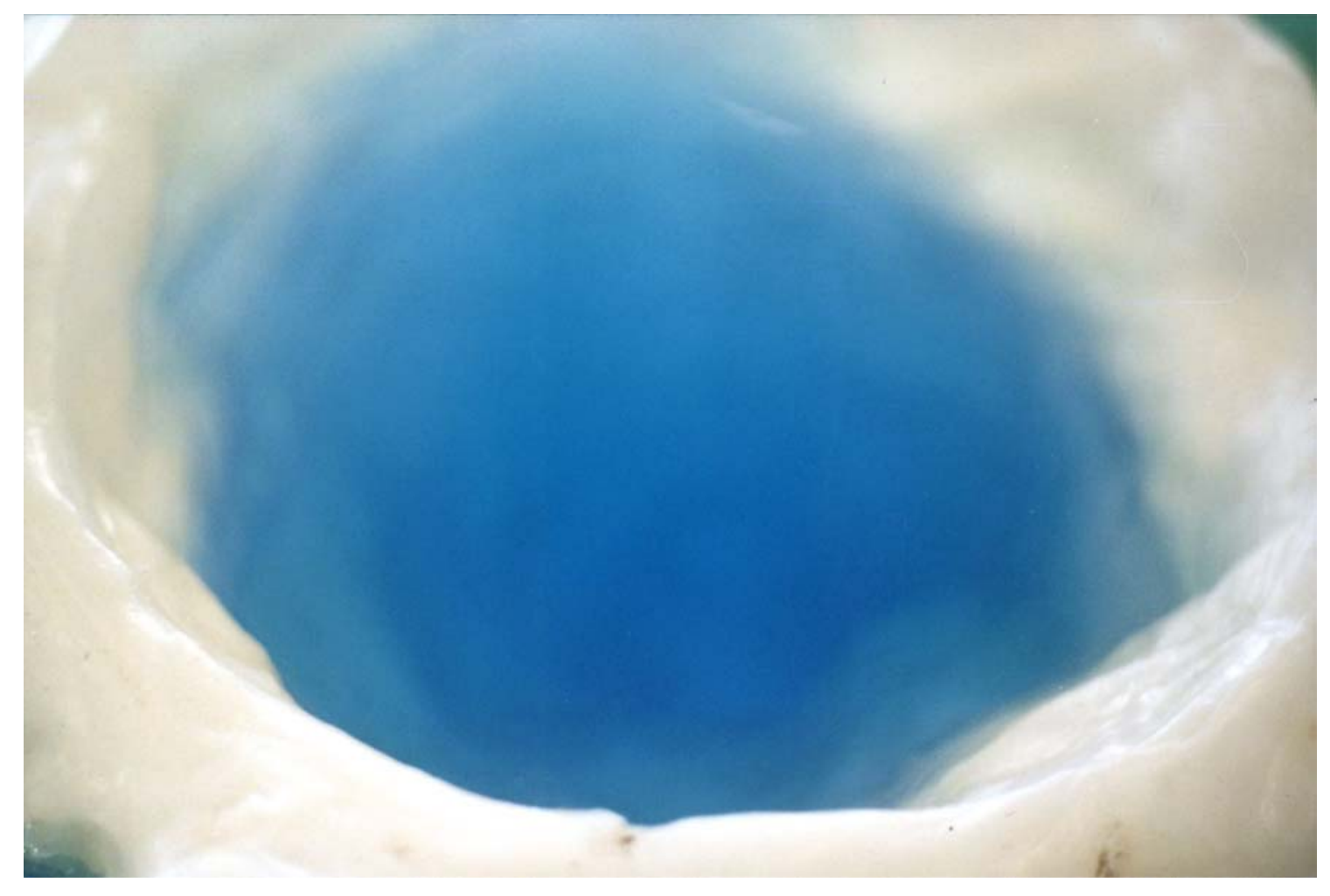

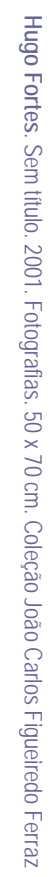

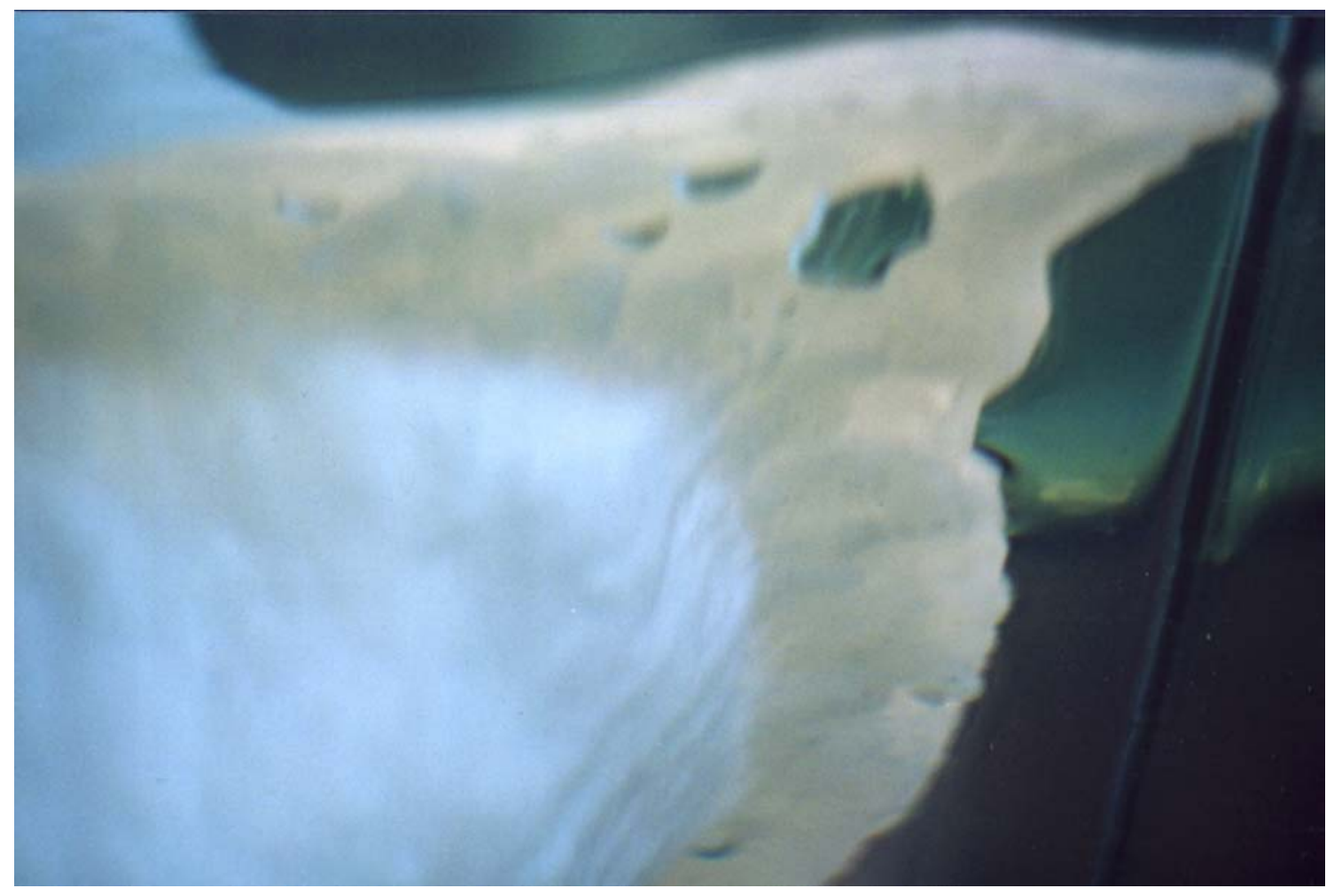


A partir de minha vivência em Berlim, tive a oportunidade de ter um contato mais próximo à água em sua paisagem natural, já que morei ao lado do belo rio Spree. Diariamente atravessava-o caminhando e observando as alterações de sua água sob a ponte. Este fato levou-me a desenvolver uma extensa série de mais de duzentas fotografias, na qual capto os reflexos formados na superfície aquática. As fotos, de grande variação formal e colorística, assemelham-se a imagens abstratas complexas e orgânicas. Pode-se enxergar uma certa proximidade formal entre essas fotografias e imagens fractais formadas por computação gráfica.

Embora tenham sido realizadas com uma câmera digital, tais imagens são fotografias sem qualquer alteração gráfica em computador, que apenas captam os reflexos produzidos na água. A sua proximidade com as imagens eletrônicas computacionais, bem como a sua tendência à abstração são fatos que me interessam especialmente.

Ao enxergarmos os reflexos aquáticos fugazes produzidos no mundo sensível como se fossem imagens totalmente abstratas, criadas em computador, damo-nos conta de quanto a nossa percepção atual é dominada pelos códigos visuais tecnológicos e coloca-os como parâmetros a priori para nosso olhar sobre o mundo. $O$ cidadão comum, que atravessasse a mesma ponte sobre o rio Spree em Berlim, talvez não percebesse tais configurações fractais efêmeras que se orquestram na superfície da água, ou talvez nem ao menos se desse ao trabalho de observá-las. A fascinação pela tecnologia, no entanto, não o impede de enxergar gráficos computacionais abstratos quando observa minhas fotografias.

O que procuro fazer enquanto artista, é, além de tornar visíveis as imagens fugazes do mundo dos reflexos, revelar as artimanhas nas quais se envolve nossa percepção, num tempo em que nossos olhos estão mais acostumados a ver pixels e bytes do que a deter-se com as correntes da natureza.

Obviamente existe uma relação entre estas imagens e a pintura. De maneira semelhante aos impressionistas, interesso-me pelas variações fugazes da luz refletida na superfície aquática. Apenas as capto de maneira mais instantânea, isolada nos segundos, revelando o intrincado detalhismo orgânico com que a água insiste em reapresentar o mundo. Se as imagens da água são ao mesmo tempo abstração e concretude do mundo, questionam-se todas as verdades sobre a presença e a representação, tornando tudo interstício e fugacidade. 

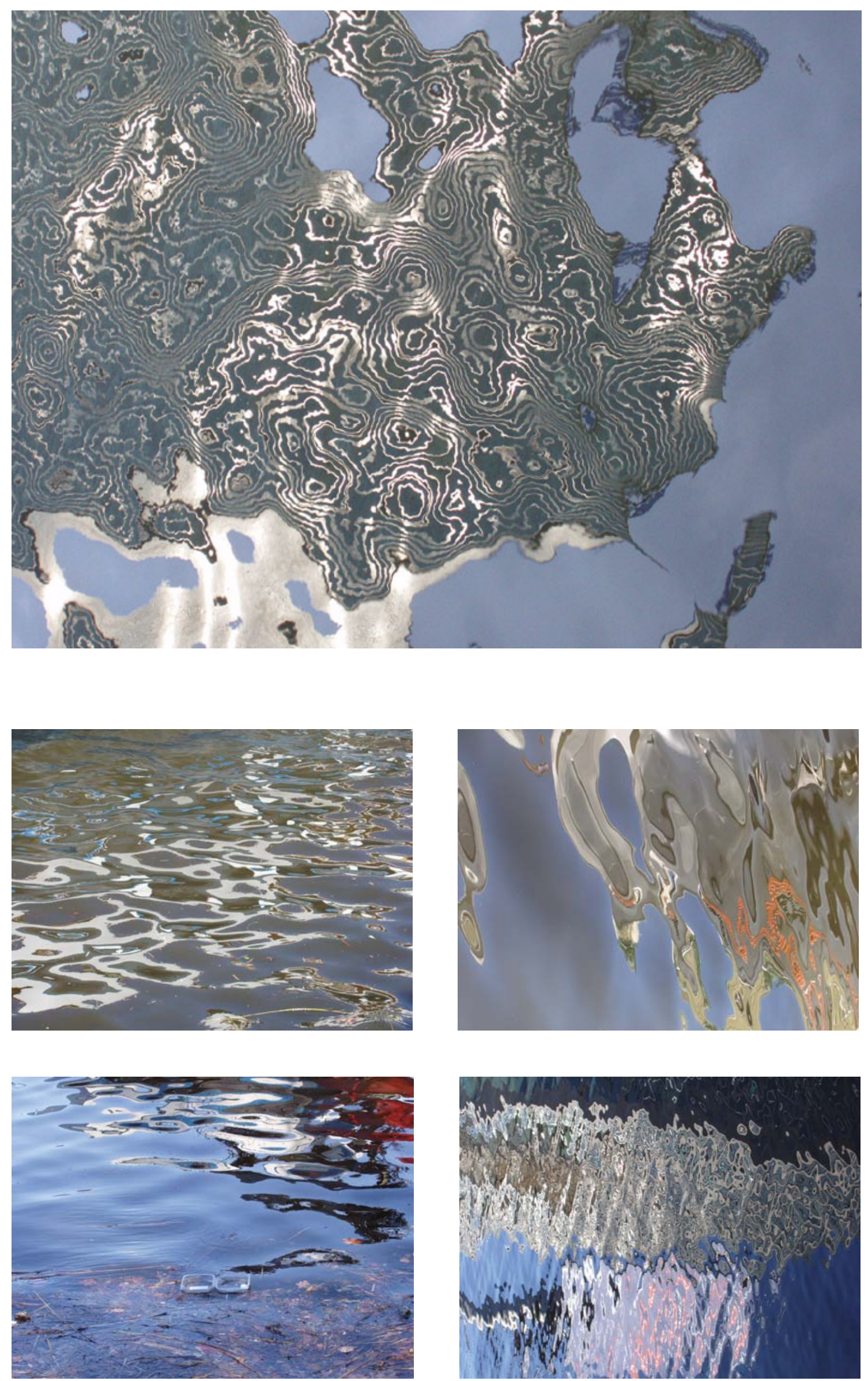

Hugo Fortes. Série Reflexos. Fotografias. Dimensões Variadas. 2004 - 2006 

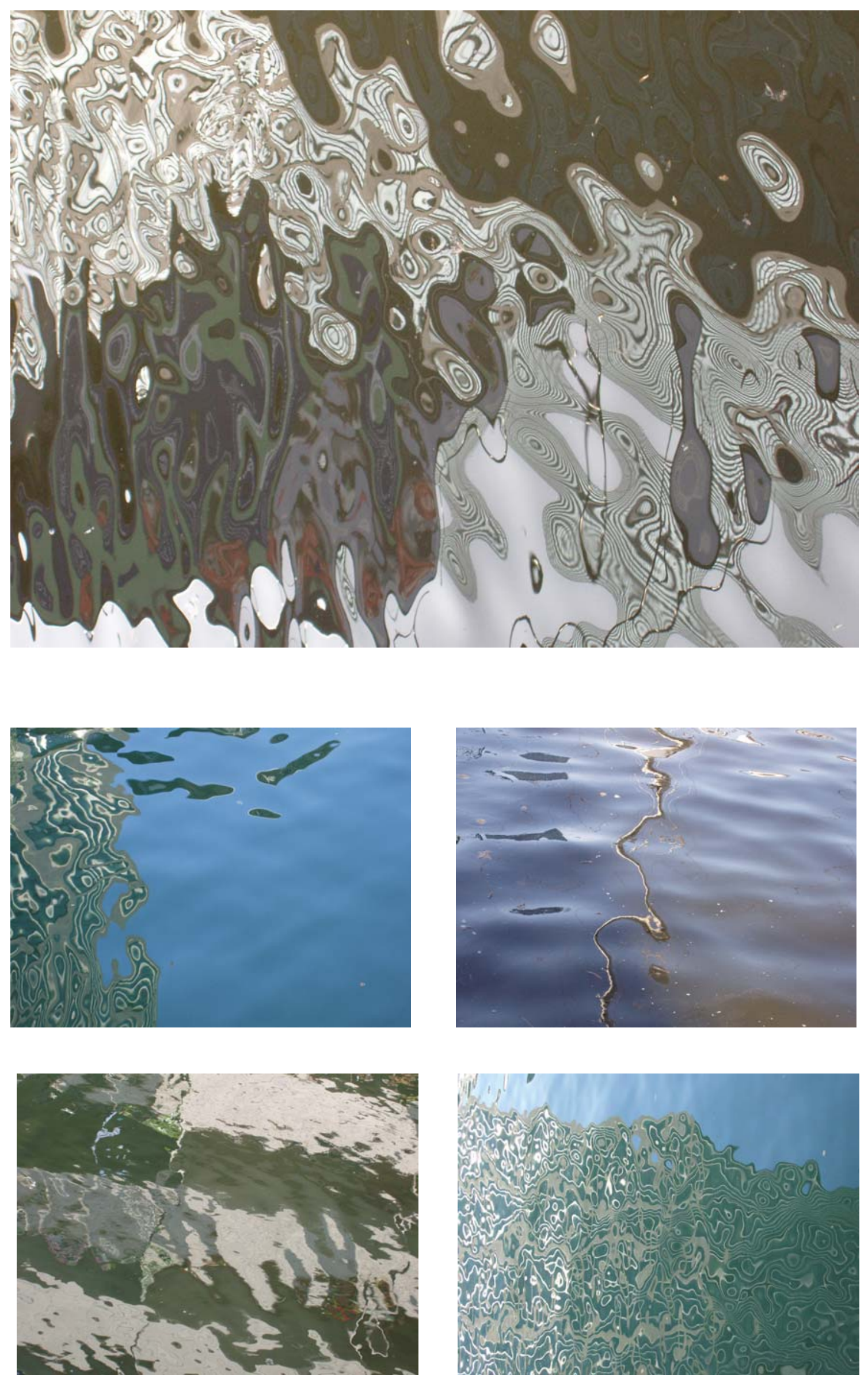

Hugo Fortes. Série Reflexos. Fotografias. Dimensões Variadas. 2004 - 2006. 
A dimensão do tempo reflete-se nestas imagens não apenas pelo congelamento dos segundos em suspensão, mas pela própria impossibilidade de se fotografar duas imagens iguais do mesmo rio. Após realizar uma grande série de fotografias dos reflexos no rio em diversas condições de luminosidade que produziam imagens bastante diferentes umas das outras, vi-me confrontado com uma dimensão do tempo ainda mais ampla, que alterava as condições climáticas da paisagem de maneira bastante radical. Passei a fotografar então no frio inverno alemão, que congelava os rios, quase eliminando os reflexos, porém traçando novas linhas e desenhos monocromáticos e novamente abstratos. Enquanto nas imagens produzidas no verão destacam-se as linhas sinuosas e orgânicas do movimento incessante produzido na água, nas fotos do inverno as linhas parecem ter sido traçadas geometricamente e a imagem se apresenta como um quebra-cabeça de polígonos, como uma colagem de superfícies parcialmente translúcidas ou parcialmente opacas.

É impressionante como a natureza altera suas configurações visuais em função do tempo e e da temperatura. A superfície endurecida do gelo causou-me grande estranhamento, por se tratar de uma matéria para mim tão conhecida mas ao mesmo tempo nunca assim visualizada. Tanto as imagens dos reflexos fractais como as imagens do rio congelado apontam para uma tentativa de compreensão do tempo e as alterações que ele provoca no espaço.

A água, em sua fluidez, movimentação e profundidade, ou paradoxalmente em seu congelamento estático e na superfície efêmera do gelo cumpre novamente a função de simbolizar um tempo que escoa, transforma os espaços e provoca fissuras em nossa percepção. 

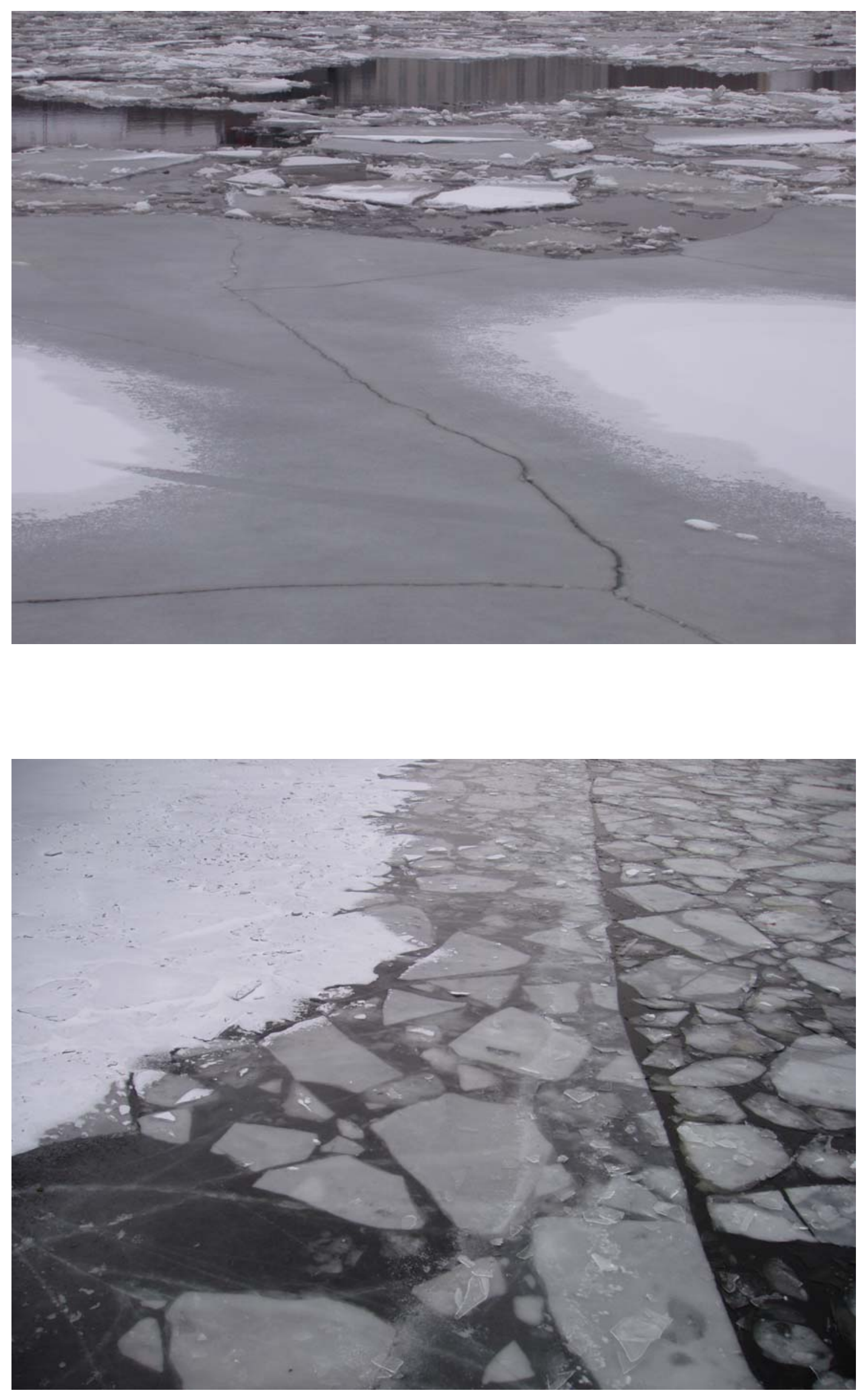
Hugo Fortes. Série Gelo. Dimensões Variadas. 2004 - 2006.
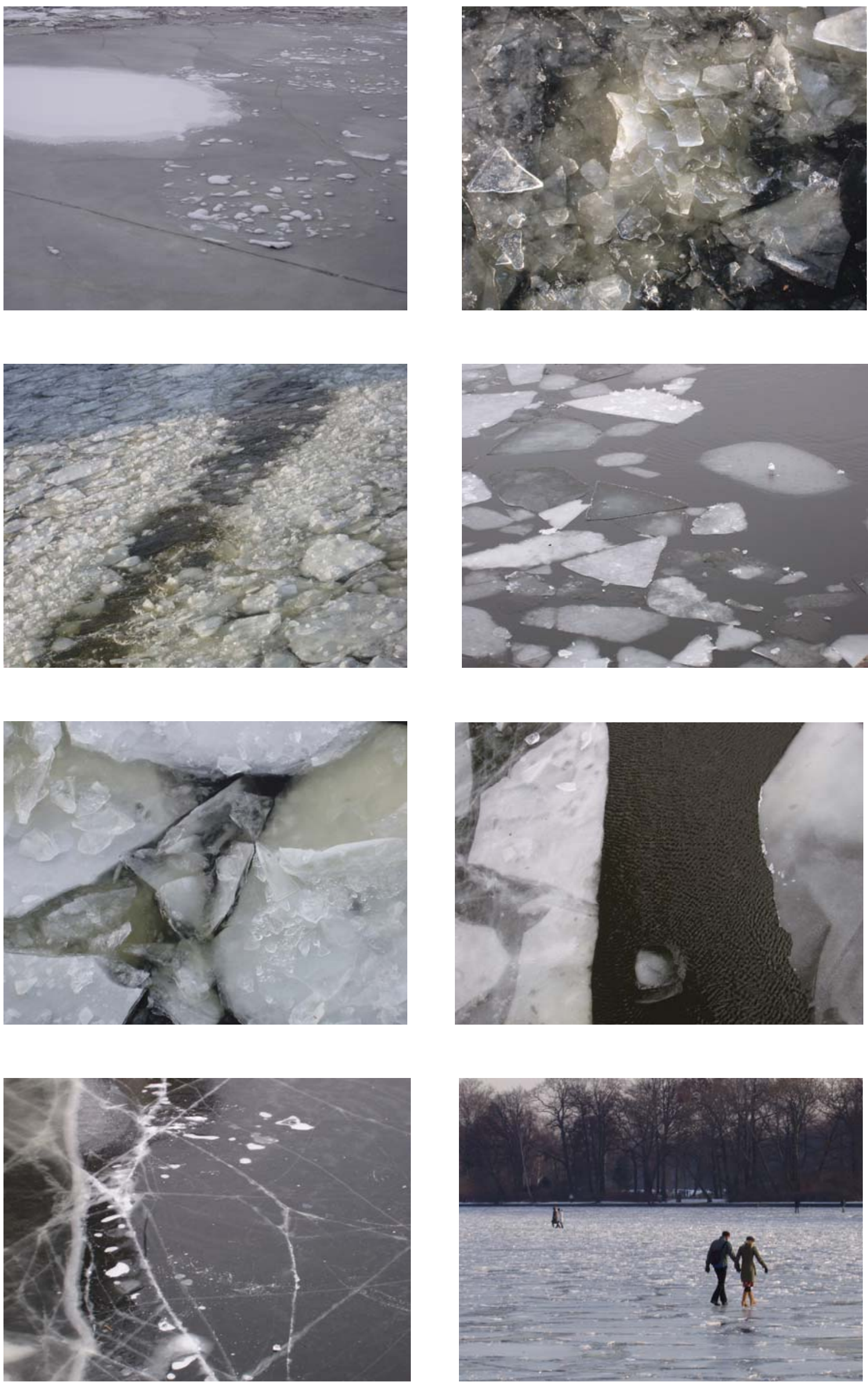


\title{
4.8.Tempo, trânsito, linguagem, fluxos
}

\author{
A água passa por uma frase e por mim, \\ Macerações de sílabas, inflexões, elipses, refegos. \\ A boca desarruma os vocábulos na hora de falar \\ E os deixa em lanhos na beira da voz.
}

Manoel de Barros

A questão da fluidez e de sua suspensão e interrompimento tem sido tratada em grande parte de minha obra através do emprego simbólico e material da água e seus processos fenomenológicos. Porém não é apenas no meio aquático que se pode encontrar a fluidez.

Como sinônimo de fluidez, a palavra "fluência" pode ser aplicada igualmente no português ou no alemão "Flüssigkeit" ${ }^{28}$ tanto na descrição dos processos discursivos da linguagem, bem como para indicar o deslocar de um líquido. É comum dizermos que certa pessoa fala fluentemente uma determinada língua. O processo discursivo é essencialmente temporal; é no desenrolar dos minutos que falamos, escrevemos ou lemos palavras. O fluir de um líquido também se dá no tempo. Seriam então as frases, rios de palavras nas quais flui nosso pensamento?

A linguagem poética busca muitas vezes a interrupção deste fluxo, desviando-o de seu curso natural, alterando e distorcendo seu sentido original e revelando nuances e refrações do significado das coisas. Como já foi dito, o interesse pela palavra tem me acompanhado ao longo de minha produção, quer seja na construção poética dos títulos dos trabalhos, quer seja na utilização real da palavra como elemento do trabalho plástico. As palavras comparecem em minha obra, não de maneira incisiva, puramente cerebral ou determinante, mas de maneira enviesada, introduzindo sutilezas e modulações poéticas.

Nos primeiros trabalhos que realizei com água, nota-se já esse interesse pela linguagem verbal. O título destes pequenos trabalhos, incorpora-se à apresentação visual da obra. Os trabalhos, desenvolvidos em 2000 chamam-se respectivamente "Afogo" e "Algo/Alga". 
Hugo Fortes. Algo/Alga. 2000. Vidro, água, alga e transparência impressa. 12 × 20 × 25 cm. Acima: imagem da palavra algo, impressa sobre a transparência. 

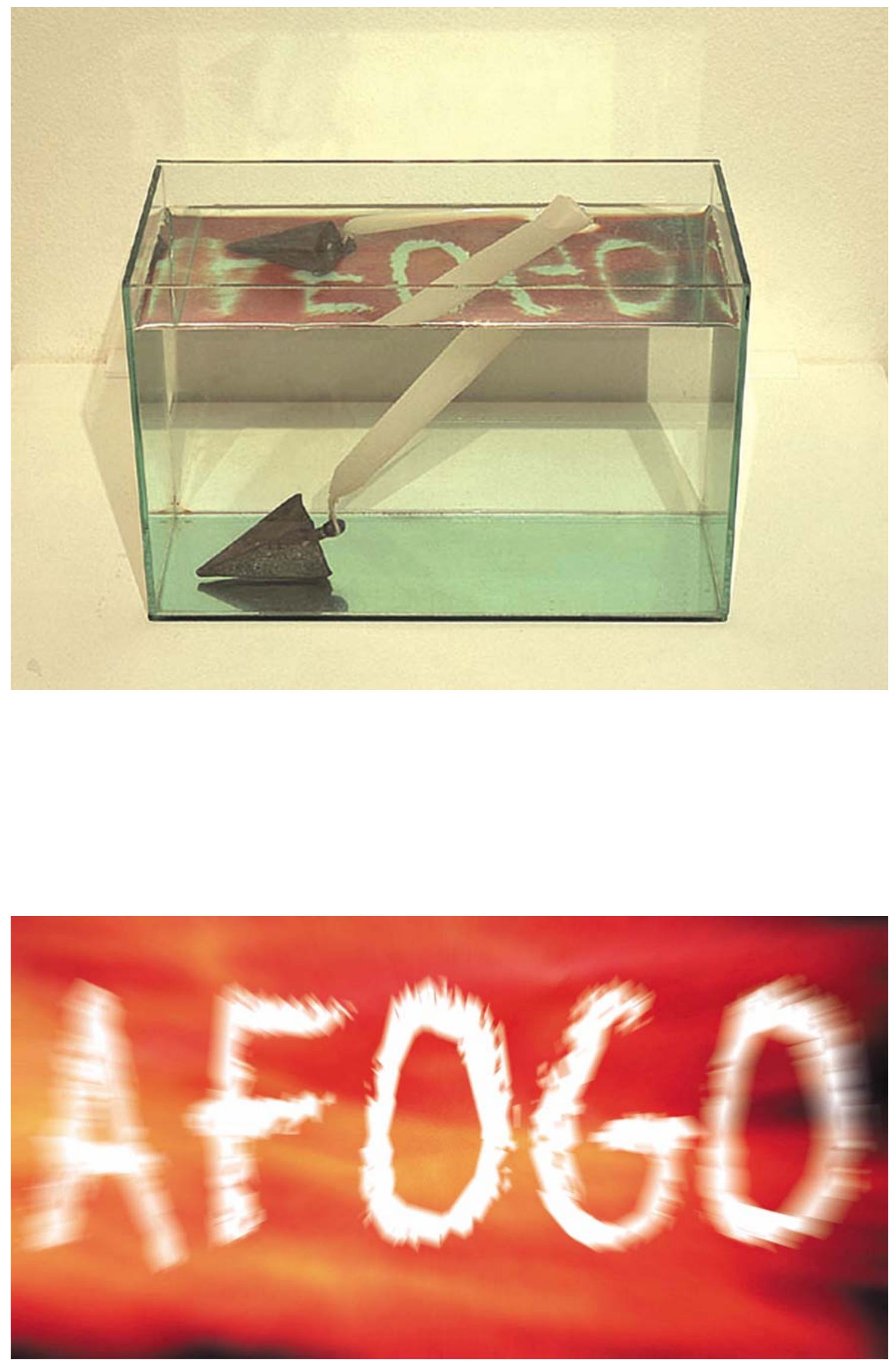

Hugo Fortes. Afogo (acima). 2000 Vidro, água, vela, chumbo e imagem. 12 × 20 × 25 cm. Abaixo: imagem da palavra "Afogo" colocada sob 0 aquário. 
Em "Afogo" é inserida em um pequeno aquário uma vela presa pelo pavio a um peso de chumbo. Ao invés da chama acesa, o que se vê é a vela afogada e impossível de ser acesa. Ao se aproximar do aquário no entanto, nota-se um reflexo de chamas de fogo onde esta escrita a palavra "Afogo". Porém esta imagem não aparece quando se observa a obra de longe, mas somente ao se debruçar sobre a água do aquário é possível ver o reflexo do fogo. Estabelecendo um contato lúdico com o observador, este trabalho utiliza as ilusões de óptica proporcionadas pela água para lançar questionamentos sobre os opostos fogo e água, peso e leveza, baseando-se na dualidade poética da palavra, que assinala um território de impossibilidades. Afogo, palavra ligada à morte na água, passa a soar como "aFogo" (não fogo) ou então como "há fogo".

O trabalho "Algo/Alga" consiste também de um pequeno aquário onde foi inserida uma alga verdadeira de cor branca. Na superfície da água, sobre a alga, está uma transparência onde se vê a palavra "algo" escrita em um tom de azul muito leve. Pela inserção na água, a transparência torna-se praticamente invisível e a palavra "algo" parece estar escrita na própria água. O trabalho trata de maneira irônica e praticamente tautológica da imaterialidade da palavra confrontada à materialidade da alga. A aparência do trabalho é de algo evanescente, em que matéria e palavra são como o corpo e a alma de um mesmo ser.

Nos dois trabalhos nota-se uma tentativa de conferir um corpo material à linguagem verbal. O signo linguístico é posto aqui em suspensão, alargando seu conteúdo semântico ao ser colocado em contato e contaminação com o mundo material sensível. A palavra perde seus contornos precisos enquanto signo ligado à cultura convencionada pelos homens e passa a ser tratada como elemento plástico e material. Em minha produção mais recente, observam-se procedimentos semelhantes a esse, como no trabalho "Molhar Molière" já citado, no qual os livros mergulhados na água tornam-se matéria perecível. Nos trabalhos "Algo/Alga" e "Afogo", que marcam o início de minha produção de obras em que a água é utilizada como material, pode-se notar também vários outros elementos recorrentes em minha obra, como o interesse pela flutuação, reflexão e transparência, as contradições entre leve e pesado, e as discussões a respeito dos conceitos de natureza e cultura.

Uma vontade de colocar em suspensão as coisas e os significados do mundo parece atravessar toda minha poética. Ora coloco em suspensão os vocábulos, interrompendo seu fluxo temporal verbal, ora suspendo os próprios corpos físicos das coisas, fazendo-os flutuar no líquido e no espaço. 


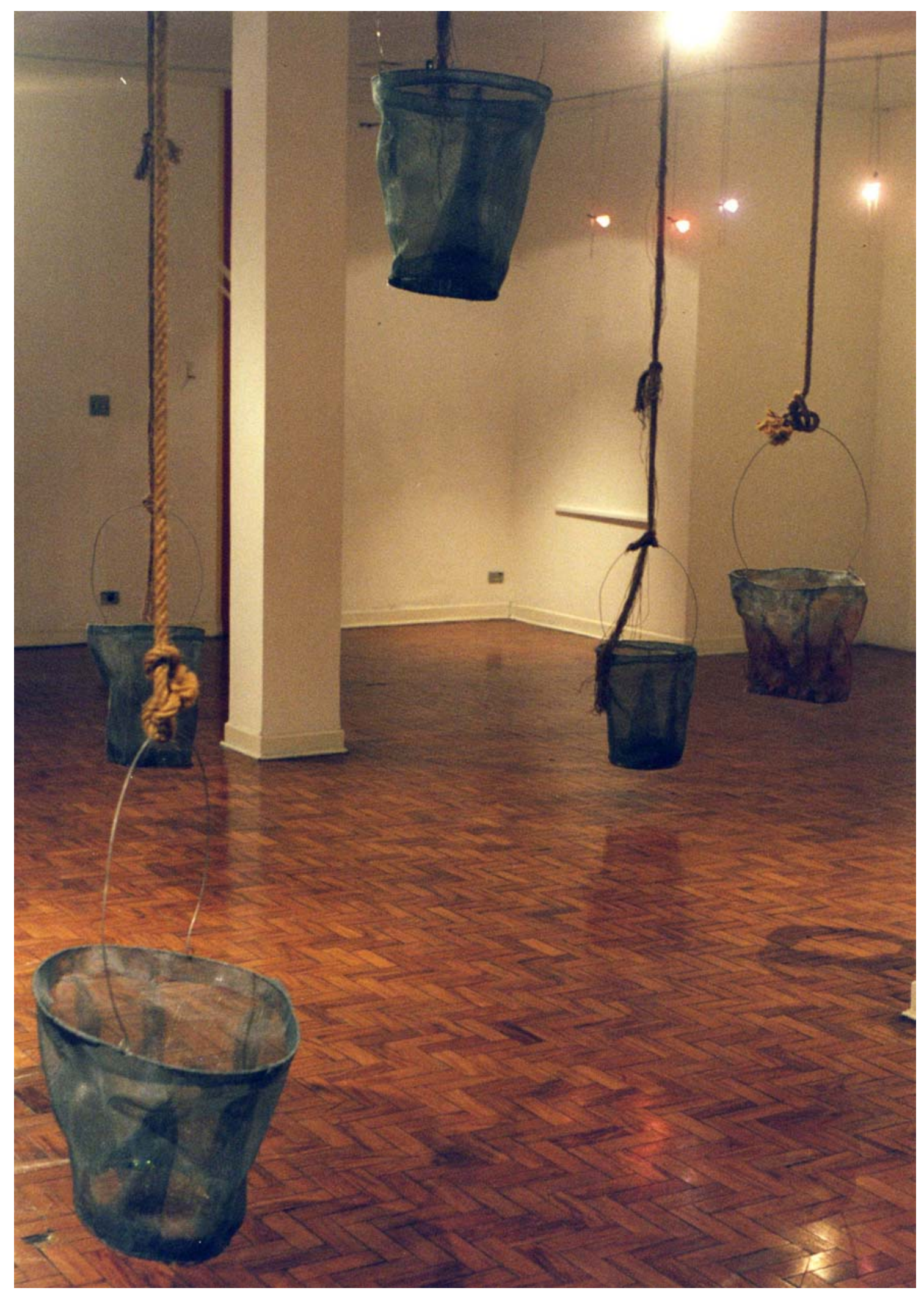

Hugo Fortes. Poço. 1997. Instalação: telas de nylon, resina, cordas, arame e imagens. Centro Universitário Maria Antônia e Casa de Cultura de Santo Amaro. 
Mesmo nos trabalhos em que não utilizo água, este procedimento se manifesta. Na instalação "Poço", realizada em 1997 no início de minha trajetória, deixo claro desde cedo meus propósitos.

Poço é um conjunto de esculturas que lembram baldes, suspensos no ar por pesadas cordas. Partindo da memória do local em que foi montado originalmente,o prédio histórico da atual Casa de Cultura de Santo Amaro, em São Paulo, mas que anteriormente já foi um mercado onde havia um poço, procurei fazer retornar estas lembranças ao local através da presença dos baldes suspensos. Os baldes eram cheios de lama, alguns sem fundo e outros com um fundo em resina transparente e fotos do próprio local. Eram baldes que não serviam para conter, pois eram esculturas de tela de nylon vazada e transparente. Sua aparência é quase imaterial e fantasmática.

Embora ainda não estivesse usando propriamente a água neste trabalho, seu indício já estava lá pela presença dos baldes. O fato dos baldes estarem em suspensão conferia ao trabalho uma leveza que, no entanto, era contrastada com a grossura das cordas que os prendiam e com a rusticidade dos materiais.

Procurei evocar a idéia de um tempo que não está mais presente, um tempo em que ainda haviam poços, buscando memórias soterradas no fundo da terra.

Este mesmo tempo suspenso, oscilando diante da impossibilidade de conter seu fluxo e agarrando-se à vacuidade de sua fluidez é também o foco de vários outros trabalhos que realizei, nos quais a água não aparece obrigatoriamente como tema ou matéria.

Em meu primeiro vídeo "Vem/Vai", realizado em 1998, imagens das mais variadas procedências a respeito do nascimento (vem), dos encontros amorosos e sexuais (vem/vai) e da morte (vai) eram arranjadas em uma sequência ritmada a partir de um poema sonoro constituído apenas destas duas palavras. É o escoar da vida que está aqui em jogo.

Também em minha produção mais recente em vídeo observa-se este interesse pela fluidez do tempo, por sua aceleração ou desaceleramento. No vídeo "Vigia" (2005) vemos por cerca de 20 minutos uma imagem quase estática de um cão que lentamente adormece, em um estado de vigília entre o sono e a consciência. $\mathrm{O}$ vídeo pretende introduzir uma noção de tempo de outra ordem, que escapa à pressa do homem contemporâneo. Mas mesmo na correria urbana, há momentos em que o tempo se ralenta e a cidade adormece. É exatamente este momento que busco captar no vídeo "Noturno". 
O lento trafegar dos carros na fria madrugada, os últimos passantes a retornar para suas casas e o cair incessante da neve que cobre as ruas de silêncio e solidão é o que se vê neste filme. O tempo aqui é trânsito e tráfego, porém em seu momento mais lento e sonolento.

Trânsito e tráfego são também o assunto de "Übergang", vídeo realizado em 2005. Filmado através dos reflexos produzidos nos vidros do metrô, "Übergang" mostra a sobreposição de imagens transparentes da paisagem do trecho urbano que o trem percorre e de seus passageiros. As imagens fluem incessantemente em direções contrárias, misturando-se umas às outras e tornando-se pura transparência e virtualidade. A situação de estar em trânsito, num fluxo de imagens e sensações fugazes é o que se vê nesta obra.

A busca de processos efêmeros, do benefício da dúvida produzida pela transparência e pela refração, dos atritos e interações entre a paisagem natural e humana, da colocação em suspensão do tempo e dos sentidos, e o desejo de flutuação têm sido o cerne de minha poética artística. Se a água é elemento recorrente em minha produção, é por materializar muitos destes processos. Seja lá o correr dos rios, o alargamento de horizontes, as profundezas do olhar, a leveza e a flutuação dos corpos, as incertezas do homem perante o mundo natural, o fluxo da história, a dubiedade translúcida das palavras, a pressa da cidade e o seu adormecer - em tudo há fluidez e nada escapa à força implacável do tempo.

Que a correnteza me leve e que eu possa aproveitar os minutos... 


\section{Mergulho}

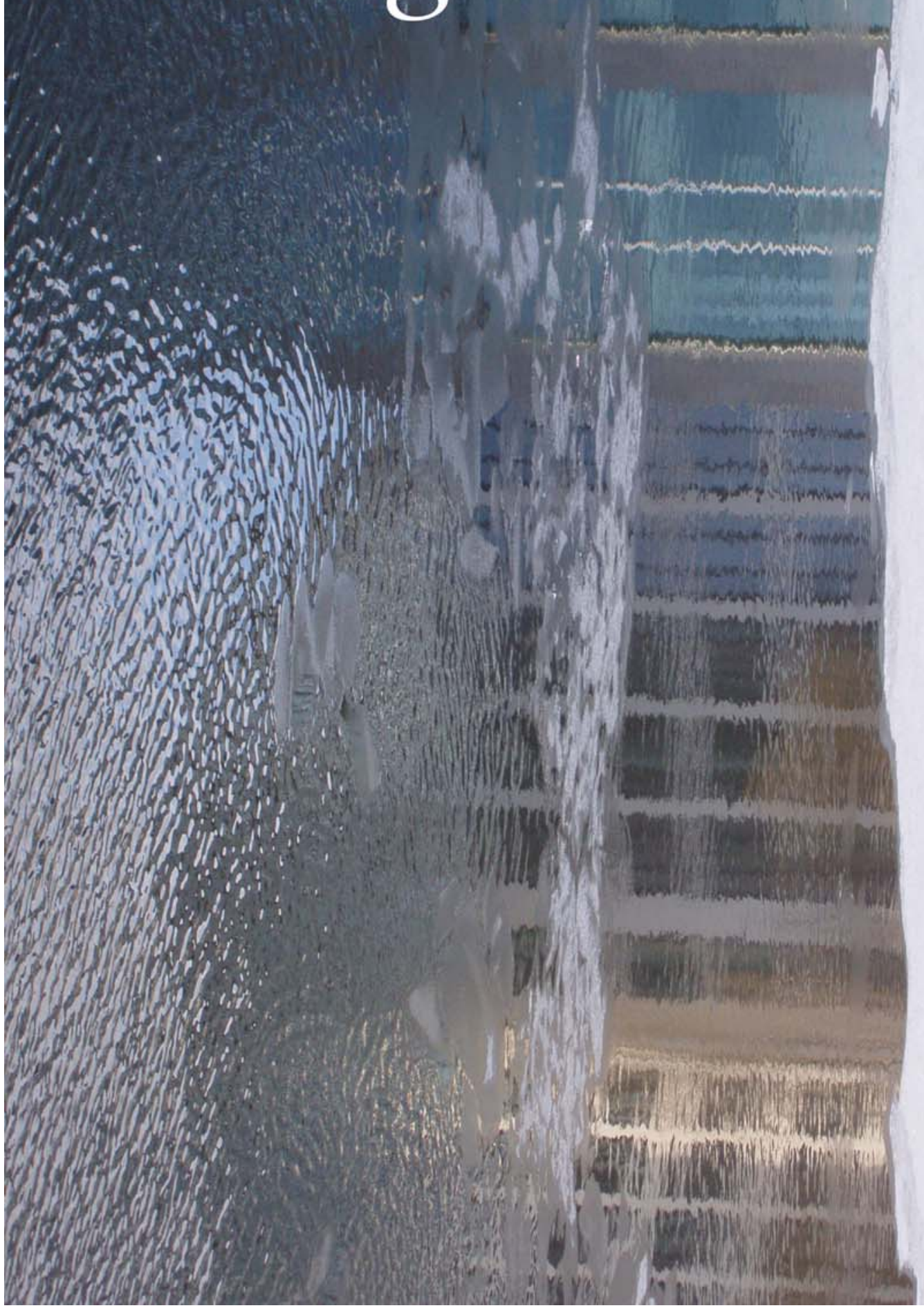




\title{
5. Água: Fenômenos e significação.
}

\subsection{Natureza como ideal e conflito}

\begin{abstract}
"Tudo isto posto, é preciso observar que o par antitético 'natureza versus cultura' constitui um modelo cultural extraordinariamente agudo e prolífico para descrever a dessubstancialização crescente da natureza (na esteira do avanço imperativo da racionalidade tecnológica) como a marcha progressiva da arte moderna em direção à reflexividade de seus meios; assim, a uma razão resplandecendo como o triunfo subjetivo da arte autônoma correspondia, no território da vida social, a ascensão irresistível da razão instrumental. (...) a visão da natureza na imaginação moderna aos poucos revelar-se-ia condenada a um horizonte ideal, a aparecer transfigurada sob o sintoma de uma perda - e tanto faz se nos referimos à natureza, refúgio da subjetividade romântica e irracionalista, ou à natureza clarividente da mentalidade clássica, solo primordial do reformismo da vertente construtiva e produtivista da arte moderna."
\end{abstract}

O contato do homem atual com a natureza ocorre não mais de uma forma direta e próxima, mas é mediado pelo discurso social e científico. Se por um certo tempo o homem viveu próximo à natureza, convivendo com seus fenômenos e desenvolvendo uma percepção bastante individualizada deles, hoje, com o advento dos meios de comunicação, o acesso à ciência na sociedade globalizada e a vida em metrópoles, sua relação com o mundo natural sensível ganhou véus de complexidade, que ora pretendem revelar um conhecimento mais objetivo e racional da natureza, ora tendem a torná-la distante e inatingível.

As percepções históricas da natureza como cenário agradável para a vida social ou suas simbolizações como depositária de conteúdos espirituais e religiosos, são hoje acrescentadas do discurso que a ciência realiza sobre ela. Desta forma, a presença da água na paisagem, que, entre os renascentistas era vista como fonte de vida espiritual, para os holandeses seiscentistas e os venezianos do século XVIII serve como cenário para o desenvolvimento da vida social e para os românticos reveste-se de um tom solene e sublime, traduzindo os estados da alma, pode ser vista hoje como um recurso natural em crescente escassez, que deve ser canalizado, tratado e conservado para o desenvolvimento sustentável das gerações futuras. Percebe-se uma mudança de tom no discurso sobre a água. Não quero dizer que o discurso tecnológico e a busca de uma observação racionalizada e prática da natureza seja 
uma exclusividade da atualidade. Já em Leonardo da Vinci é possível enxergar esta busca por uma racionalidade em seus projetos hidrológicos. 
O que ocorre, entretanto, é que na sociedade atual o acesso a ciência, pelo menos em seus níveis primários, é permitido ao homem comum, que ouve falar sobre alterações cromossômicas de uma planta transgênica ou do desvio de rios para a construção de uma hidroelétrica, sem ao menos experienciar a sensação de brincar com um matinho molhando os pés em um riacho.

A natureza encontra-se hoje esquadrinhada pela ciência e torna-se cada vez mais artificial. A produção da imagem da paisagem contemporânea, além de ser informada por toda a produção artística histórica anterior à atualidade, incorpora concepções e modelos advindos da biologia, da arquitetura e da engenharia, da física, da meteorologia e das mais variadas ciências. Principalmente a partir do século XVIII diversos artistas "naturalistas" registraram a natureza em suas particularidades objetivas, criando imagens que serviram muitas vezes para estudos científicos de botânica e geografia, por exemplo. O artista contemporâneo tem acesso a essas imagens e sua visão de mundo já vem contaminada por elas e por outras imagens fotográficas e midiáticas ou por gráficos científicos que descrevem o mundo a partir de um ponto de vista diverso daquele da atividade artística. Assim, a relação atual do artista com a natureza não é mais tão direta e fundante, mas está sujeita à interferência de camadas de sentido oriundas da ciência e da comunicação social.

Da mesma forma, a paisagem, que se observa hoje, em muito difere da paisagem vista por Da Vinci ou por Caspar David Friedrich. Basta olharmos ao nosso redor para nos darmos conta de um espaço habitado por novas construções arquitetônicas e paisagísticas, desenvolvidas com tecnologia cada vez mais moderna. Em sua tese de doutorado "Paisagem Portátil", o artista brasileiro Daniel Acosta descreve esta nova realidade, nomeando-a de "Tecnopaisagem - A construção tecnológica dos ambientes artificiais nas grandes cidades, como um mundo paralelo ao da natureza, que toma impulso principalmente a partir dos séculos XVIII e XIX como conseqüência da industrialização, e que é acelerada durante todo o século $X X$, configura o que hoje, de acordo com diferentes autores podemos chamar: paisagem urbana (Nelson Brissac), paisagem construída (Aldo Rossi), paisagem geográfica (David Harvey), tecnopaisagem (Kroker e Cook), cityscape (Jennifer Siegal), segunda natureza (Laymert Garcia dos Santos) ou ainda tecnocosmo(J.Prades)"29 


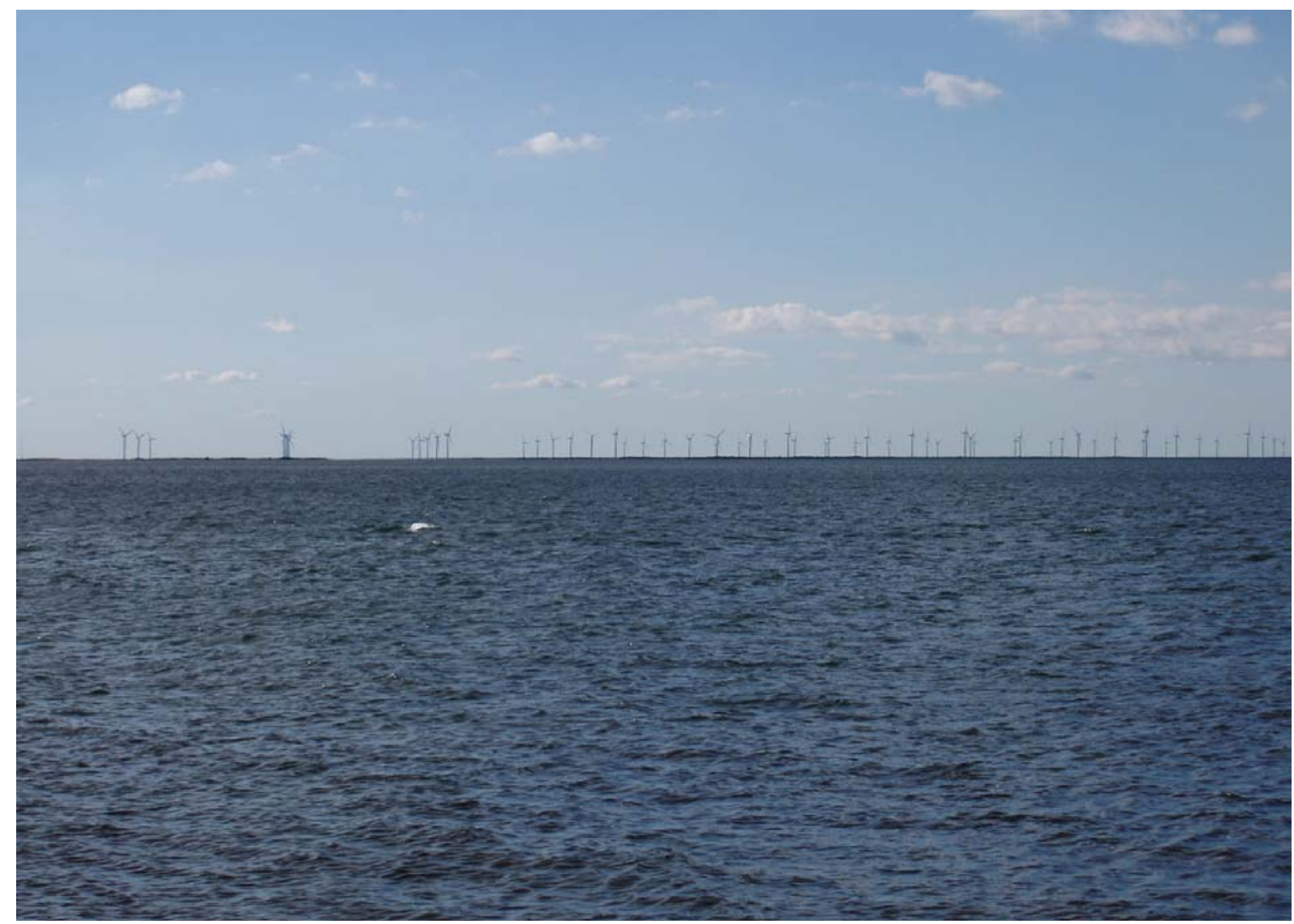

Esta nova paisagem constitui uma alteração não só do mundo visível, mas do próprio espaço experiencial em que o homem convive e atua. Também é nesta nova paisagem que o artista contemporâneo desenvolve seu pensamento e sua obra. No caso específico da água nota-se igualmente esta nova ordem. Banhamo-nos em águas aquecidas, encanadas e tratadas; é mais comum mergulharmos em piscinas do que em mares, rios, ou lagos; construímos diques, eclusas, açudes e métodos de irrigação artificial; canalizamos rios e desviamos seu curso; compramos água engarrafada e com diversos sabores; coletamos e armazenamos as águas da chuva; navegamos em modernos barcos, jet skys e submarinos; construímos hidroelétricas; instalamos torres de energia eólica e bases de extração petrolífera em costas marítimas.

Diversos artistas citados neste trabalho partem destes pressupostos para a criação de suas obras. Olafur Eliasson, por exemplo, recria ambientes naturais através da tecnologia, incorporando-a assumidamente à apresentação de suas obras. Seus trabalhos situam-se entre a busca de um novo Sublime e a mecanização tecnológica dos efeitos naturais. São os detritos da deteriorada paisagem urbana que a artista alemã Kirsten Pieroth expõe, quando transporta poças d'água das redondezas para o espaço interno da galeria. Já Susanne Lorenz interfere diretamente sobre a paisagem de um rio ao introduzir em seu curso, com a ajuda da tecnologia arquitetônica, uma piscina que flutua, já que o homem não pode mais nadar nas águas fluviais poluídas. 


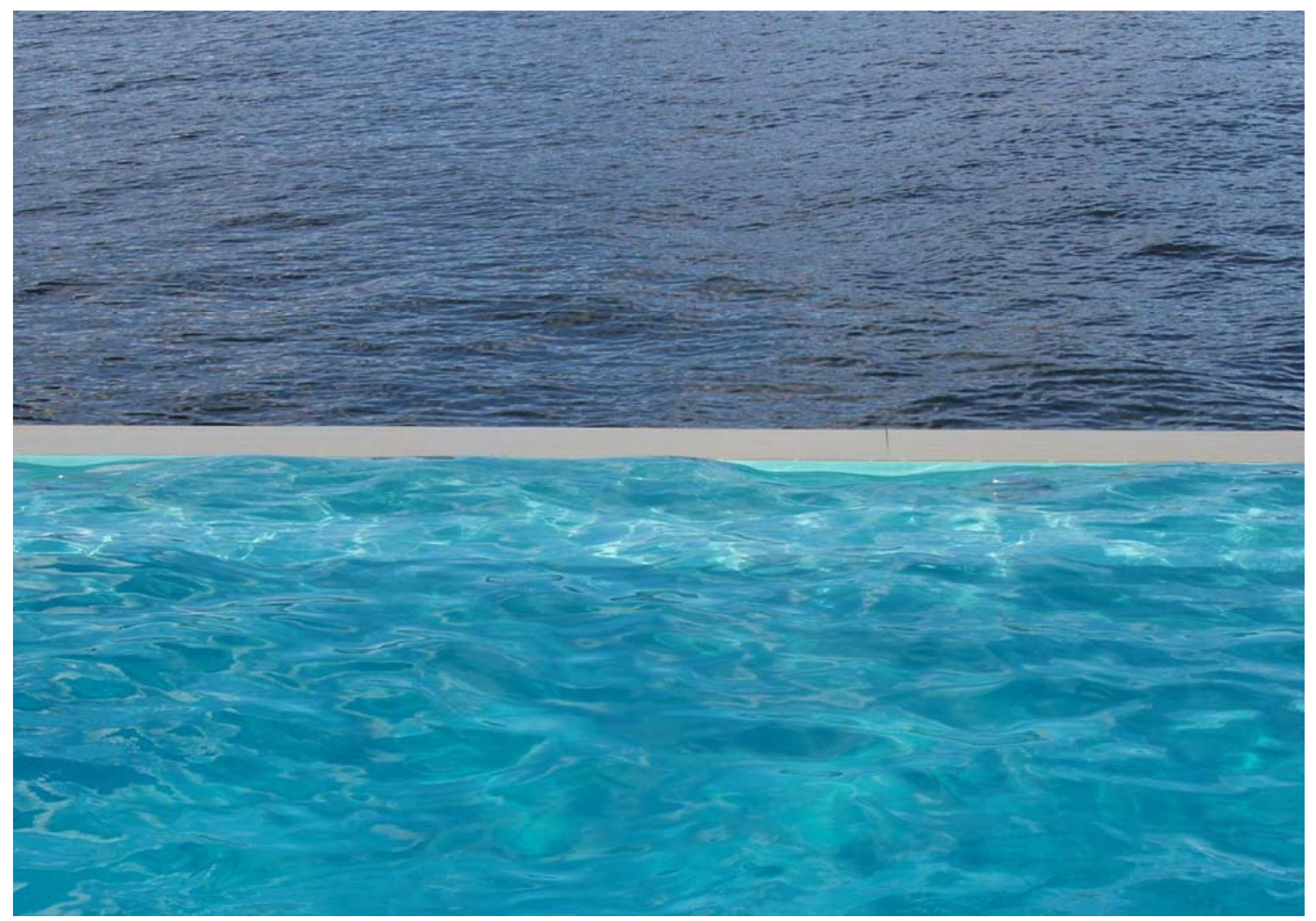

São questões semelhantes que me movem, quando produzo rios encaixotados em aquários, crio horizontes artificiais em contato com a arquitetura urbana, realizo vídeos sobre o movimento mecânico dos processos de irrigação artificial ou desenvolvo uma série de fotografias nas quais os reflexos da paisagem na água assemelham-se a imagens eletrônicas.

No mundo contemporâneo, a tradicional dicotomia natureza versus cultura parece não mais se colocar como uma oposição dualista, mas como uma relação de dependência mútua. Difícil saber até que ponto as condições tecnológicas, científicas e culturais alteram e recriam a natureza. Será um alimento transgênico produto cultural ou vegetal?

Se em outras eras o discurso religioso em suas mais variadas nuances e graus de profundidade determinou a percepção do mundo natural pelos artistas, hoje é necessário considerarmos também o discurso da ciência como um componente dos subtextos da arte. Na arte contemporânea, o homem passa a trabalhar não somente com a representação imagética do mundo, mas a interferir sobre ele em sua tridimensionalidade e materialidade, utilizando-se da tecnologia disponível.

Assim, a análise da produção artística contemporânea deve levar em conta a associação entre os processos fenomenológicos ocorridos no corpo material da obra 
e os processos simbólicos que ela propõe através de sua rede de referências poéticas, baseadas simultaneamente na vivência individual do artista e na história e sociologia das imagens.

Desta forma, creio que, ao falar da água na arte atualmente, não me basta buscar teorias que tratem apenas de seus aspectos semânticos, mas é necessário considerar também suas características físico-químicas e os processos a que está sujeita, para melhor compreendê-la como elemento. Por este motivo, empresto categorias do discurso científico da análise físico-química da água, para procurar extrair delas determinados conteúdos simbólicos que são associados a água na arte contemporânea. Não descarto porém o simbolismo histórico da água, em suas mais variadas concepções epistemológicas manifestadas nos diferentes períodos artísticos, já que todas estas concepções, sobrepostas e fragmentadas, também contribuem para a formação de um imaginário contemporâneo.

Portanto, é a partir do estudo de processos como reflexão, refração, transparência, flutuação, etc e a identificação de sua significação no contexto da arte, que procuro enxergar as poéticas líquidas contemporâneas. As categorias de análise, já citadas brevemente no capítulo anterior deste trabalho, constituem-se a partir de conceitos básicos da ciência, no que diz respeito à classificação de algumas características da água e dos líquidos. O estudo associativo entre os processos físico-químicos da água e sua conotação semântica é uma contribuição original que este trabalho apresenta, e seu desenvolvimento baseia-se tanto na pesquisa histórico-teórica sobre o assunto como em minha própria relação fenomenológica com a matéria líquida, durante o processo de criação de minhas obras. Por se tratar de um estudo inicial, esta contribuição poderá ser sempre ampliada e revista, acrescentando-se outros exemplos e campos de aplicação e de referências. As categorias aqui apresentadas não são estanques e excludentes, mas devem ser vistas como elementos transparentes, fluidos e interligados, como o próprio meio líquido. 


\subsection{Os fenômenos físico-químicos da água \\ e suas conotações simbólicas}

\subsubsection{Transparência como evidência do vazio}

"Mas dentro de um copo d'água há uma voz perdida, não a da água nem a do copo, uma voz que é preciso descobrir"

Nuno Ramos

A transparência é um fenômeno óptico presente apenas em alguns corpos do mundo material. Enquanto a opacidade garante a visualização individualizada da matéria, a transparência possibilita olhar ao longe e ver através das coisas. O ser humano relaciona-se com o mundo visível orientando-se prioritariamente pelas matérias opacas, que servem como corpos volumétricos que demarcam o espaço e assinalam afirmativamente sua presença. Porém, é somente através da transparência do ar que a visualização destes corpos torna-se possível aos olhos. Não fossem o ar e nossos olhos transparentes, não se daria a comunicação luminosa entre o mundo opaco e nossa escuridão interior. É a matéria transparente que permite a propagação da luz e o advento da visão.

Se a opacidade está ligada às certezas, pelo menos aparentes e à presença objetiva, a transparência relaciona-se às possibilidades e às revelações. Existem graus de transparência, que turvam e distorcem a nossa percepção das coisas. Ser transparente e ser translúcido são nuances de um mesmo fenômeno. Tradicionalmente atribuímos ao ar um grau máximo ideal de transparência, às vezes nem nos damos conta de sua existência. Enxergamos os corpos envolvidos pelo ar, mas dificilmente vemos o próprio ar. É apenas através da experiência da distância que podemos visualizar o ar. Em amplo espaço aéreo, como o céu, o ar ganha tonalidades azuladas, ou acinzentadas ou esbranquiçadas, dependendo do seu grau de pureza. É em seu acúmulo e extensão que a transparência revela suas nuances de opacidade, e conseqüentemente sua impossibilidade como valor absoluto ideal. Não existe nada absolutamente transparente, nem absolutamente puro.

A associação entre transparência e pureza revela-se em diversas de nossas percepções. Os cristais preciosos mais puros são transparentes. A transparência da água atesta, pelo menos pelas aparências, a sua pureza. Se os materiais precisam de uma certa opacidade para individualizar-se e exibir seu corpo físico, a transparência aproxima-se da imaterialidade espiritual. Os fantasmas são transparentes, revelam-se em bolas de cristal e atravessam paredes opacas. 
A experiência da transparência é também parte da experiência da profundidade. As profundezas do mar e a infinitude do céu só podem ser intuídas através da presença da matéria transparente. Aquilo que se deixa atravessar pela luz parece também mais fácil de ser penetrado. Uma pedra, um pedaço de madeira ou uma superfície de metal ocultam o que há em seu interior e não convidam o corpo a atravessar sua matéria. São antes de tudo anteparos para o olhar e obstáculos rígidos ao corpo. Materiais transparentes como a água e o ar não servem para encobrir as coisas e ocultá-las; são facilmente atravessados pelos olhos e permitem que o corpo se desloque em seu interior.

Mesmo o vidro, em sua rigidez que busca impedir o corpo de atravessá-lo, é sinônimo da fragilidade e representa um anteparo que está sempre em vias de se partir. Não é à toa que o vidro encobre as coisas desejadas e preciosas. Olhamos nas vitrines o que queremos possuir; a transparência nos permite desejar, apenas a dureza do vidro parece-nos lembrar das dificuldades. A transparência é veículo do desejo. Em seus diferentes graus de translucidez, ela ao mesmo tempo revela e oculta. São da mesma ordem o desejo transparente dos olhos que tateiam sedas e lingeries e o desejo dos passáros, que, ao tentar atravessar janelas, espatifam-se atordoados.

Captar a transparência sempre foi o desejo e a dificuldade de inúmeros artistas. Segundo a tradição, os artistas que defendiam a supremacia da pintura em relação à escultura, argumentavam que apenas a primeira poderia representar os materiais transparentes e os estados atmosféricos. Como já foi dito neste trabalho, Leonardo Da Vinci inumera uma série destes fenômenos ópticos exclusivos da pintura, entre os quais a representação da superfície da água. A conquista da cor na pintura, segundo as técnicas tradicionais, está ligada ao manejo da transparência de camadas de velatura que se sobrepôem até se atingir a tonalidade desejada.

A conquista da transparência também está relacionada a história da perspectiva. A ilusão de profundidade almejada pela perspectiva deve considerar a transparência do ar e das matérias translúcidas para poder representar o espaço tridimensional na superfície plana da tela. Enquanto o ar torna-se praticamente imperceptível por atingir uma transparência quase absoluta e só pode ser visualizado através das impurezas da névoa ou da poeira, a transparência da água apresenta-se de forma ainda mais ambígua, pois não oculta sua existência material como o ar, mas ao mesmo tempo torna evidente o espaço que ocupa. Um copo cheio d'água evidencia seu vazio através da transparência. A questão da transparência dos líquidos ganha especial atenção entre os pintores holandeses de natureza morta dos séculos XVII e XVIII. Uma taça de cristal cheia de água ou vinho em uma natureza morta holandesa contribui para aumentar o sentimento de vanitas, à medida em que exibe 
misteriosamente a vacuidade do espaço físico e espiritual e encarna metaforicamente o sagrado. O líquido que ali repousa, convida à contemplação e preenche a ausência da imagem do divino. A gota d'água que pousa sobre as frutas assinala a fugacidade da vida e cria micromundos cristalinos nos quais o olhar adentra e o espírito se amplia. O corpo terreno, que se putrefaz no tempo, busca na transparente vacuidade do mundo sua tentativa de sublimação. O vazio, evidenciado pela transparência, é ao mesmo tempo condição da vida terrena à qual estamos sujeitos e também espaço da busca da transcendência.

A transparência e a translucidez como poéticas de uma busca espiritual podem ser também verificadas nas obras de Caspar David Friedrich ou até mesmo nas obras de Rothko. A transparência é aqui este estado vaporoso, no qual ar e água se misturam e conferem uma presença fantasmagórica ao espaço e à luz. Boa parte da produção artística moderna, entretanto, parece rejeitar a transparência e a profundidade, para valorizar a opacidade e a concretude do mundo. A arte moderna interessa-se mais pela vida mundana e menos pelos simbolismos espiritualistas. A pintura moderna oferece-se como anteparo plano e opaco que serve como suporte para a ação do artista, que não busca mais um espaço de profundidade ilusionista.

Com a ruptura dos suportes tradicionais da arte e a introdução de novos materiais e procedimentos na produção contemporânea, a transparência surge não mais como representação construída tecnicamente pelo artista, mas como condição a priori do próprio material utilizado pelo artista. A utilização do vidro ou da água na constituição da obra de arte trazem um novo tipo de transparência, que pertence ao mundo material e impossibilita o isolamento do espaço da obra do espaço do mundo.

Para descrever a ruptura com o espaço tradicional da representação ilusionista na arte contemporânea, o crítico e filósofo Alberto Tassinari ${ }^{30}$ desenvolve o conceito de "espaço em obra". Segundo o autor "o espaço em obra" seria uma condição da produção contemporânea, na qual o espaço da obra engloba o espaço do mundo e é ao mesmo tempo incorporado por ele. Este conceito, embora não esteja necessariamente ligado aos trabalhos de artistas que utilizam água, é de especial interesse na análise destas poéticas. A transparência da água é por si só um índice dos pontos de contato entre o espaço do mundo e o espaço da obra. A transparência impede que um trabalho com água seja visto sem que haja uma interferência do espaço do mundo externo onde a obra se encontra. A transparência é a própria constatação do espaço do mundo, já que o ambiente em que circulamos é também transparente, e é a invisibilidade que permite que circulemos em sua profundidade e tridimensionalidade. Um recipiente transparente que contém água está cheio de matéria líquida, porém não oculta o espaço que esta matéria habita. Ao contrário, torna-o evidente e o transforma, refletindo-o, ampliando-o e distorcendo 
sua percepção. A transparente presença da água, ao mesmo tempo que preenche o recipiente que a contém, remete à contemplação de seu interior como se ele estivesse vazio.

A contaminação do espaço da obra pelo espaço do mundo através da transparência tem aparecido com grande frequência em minha produção artística. Em determinadas obras, como "Inventário de Horizontes" ou "Molhar Molière" este processo torna-se ainda mais claro. Em ambos trabalhos coloquei aquários no lado externo das janelas do espaço expositivo, de forma que a paisagem da rua pudesse ser vista apenas através da transparência da água. A água captava a luz do ambiente externo, refletindo-o e produzindo arco-íris no interior da sala. O espaço do mundo atravessa o trabalho e é atravessado por ele.

Diversos outros artistas contemporâneos utilizam-se da transparência dos líquidos, porém de maneiras bastante diversas. José Resende confunde a percepção ao colocar diferentes líquidos transparentes em vidros uns dentro de outros; Hans Haacke encerra simplesmente água em um cubo de acrílico para que ela evapore e condense em suas paredes; Betty Leirner apresenta lado a lado soluções químicas incolores diferentes, incluindo a água, questionando o primado da visão.

O uso da transparência nos trabalhos contemporâneos evidencia os processos perceptivos do mundo sensível, ao mesmo tempo em que nos permite tomar consciência do entorno da obra. O espaço vazio do mundo é materializado fenomenologicamente pela transparência dos materiais da obra de arte. Dependendo do artista e da obra, este espaço pode se apresentar de maneira mais ou menos simbólica, ora mostrando-se como simples constatação fenomenológica, ora mostrando-se como metáfora para o Vazio. Perceber a transparência como a simples evidência do espaço vazio físico do mundo ou como a manifestação de um espaço metafísico do Vazio é porém uma questão que escapa aos domínios exclusivos do artista e da obra e fica a cargo do observador. 


\subsubsection{Reflexão e refração como representação e virtualidade}

"O signo é ao mesmo tempo reflexivo e refratário." Bakhtin

Não é à toa que a palavra reflexão significa tanto o processo de desenvolvimento do pensamento como um fenômeno óptico. Desde o mito da caverna de Platão as questões do reflexo e da representação estão presentes na filosofia e na arte. A discussão sobre a arte como um reflexo do mundo ou sobre o próprio mundo como uma imitação imperfeita do mundo metafísico das idéias gerou inúmeras dúvidas filosóficas e discussões estéticas. A tradição renascentista atribuía a Narciso a invenção da arte, por ter sido ele o primeiro a mirar seu reflexo na superfície da água. A questão do reflexo sempre atraiu o interesse dos pintores e levou ao desenvolvimento de obras célebres, que colocam em jogo o ponto de vista do observador e do pintor e as relações entre o espaço pictórico de representação e o espaço representado. Os espelhos de Van Eyck no retrato do casal Arnolfini ou em "As Meninas" de Velázquez são apenas alguns exemplos.

A questão da representação não é objeto de estudo exclusivo da história e da teoria da arte, mas manifesta-se em vários outros campos do conhecimento. Para a semiótica, esta é uma questão fundamental. O semiólogo russo Bakhtin já definia o signo como reflexivo e refratário. O signo possuiria portanto um caráter imitativo daquilo que representa e ao mesmo tempo se distanciaria de seu referente, tendo sua própria materialidade. Para o filósofo contemporâneo e historiador da arte Robert Kudielka ${ }^{31}$, a questão da representação envolve um duplo sentido: ao mesmo tempo que uma imagem representativa torna algo presente, ela também remete a algo que está ausente. Ao longo da história, a arte oscilaria entre estes dois polos, ora levando à contemplação simbólica ilusionista, ora afirmando sua presença fenomenológica enquanto objeto do mundo.

Quando Velázquez trata da questão do reflexo representando um espelho, ele se utiliza de recursos da narrativa simbólica que permitem o desenvolvimento de uma discussão metalingüística. A função representativa da arte é posta em questão e o artista propõe um diálogo entre o espaço pictórico e o espaço do mundo, entre a ilusão e a realidade. Quando um artista contemporâneo realiza um trabalho com materiais que refletem fisicamente o mundo, os reflexos que se produzem na superfície da obra não se contém nos limites do simbólico, mas são a constatação da presença fenomenológica da matéria da obra no mundo. Se a obra contemporânea espelha fisicamente o espaço do ambiente, é simplesmente porque este a envolve e a atravessa. Uma obra que contenha espelhos ou a superfície 
refletora da água, utiliza-se da mesma matéria tridimensional que as coisas ao seu redor e não cria um campo visual totalmente distinto de seu entorno.

As imagens formadas na superfície de uma obra que contenha água não são totalmente controláveis pelo artista e dependem do ponto de vista do observador. $\mathrm{O}$ reflexo produzido na superfície da água não é a pura representação do mundo, mas é parte física dele. A imagem refletida é um índice da presença do mundo que envolve a obra. O reflexo na superfície da água não pode ser fixado como em uma imagem pictórica ou fotográfica, mas permanece instável e cambiante, mudando conforme a luz, o entorno e o olhar de quem o vê. A superfície da água revela-se aqui como um espaço de potência virtual ${ }^{32}$, que pode receber diferentes atualizações possíveis, de acordo com os diferentes reflexos que podem ser ali formados e visualizados.

A água é ao mesmo tempo refletora e transparente, o que aumenta a confusão perceptiva, pois não sabemos se as imagens produzidas na água são espelhamentos do mundo ao redor ou se estão por trás de sua superfície. A refração e a distorção das imagens no meio aquático parecem estar a meio caminho entre a transparência e a reflexão, mesclando-se com elas e criando espaços de ilusão.

O que mais me fascina no meio aquático é este campo de incertezas perceptivas que ele provoca. Se a arte produzida com água é percebida em primeira instância como "coisa em si", como objeto imanente do mundo, ela simultaneamente oferece espaços ilusionistas em sua superfície líquida, onde se formam imagens que são concomitantemente representações e partes reais do mundo sensível.

Muitos de meus trabalhos realizados como artista lidam com estas questões. No trabalho "Afogo" e em alguns dos aquários sem título utilizei imagens fotográficas que eram colocadas sob as cubas de vidro e refletidas e refratadas pelo vidro e pela água. Se o observador olha estas obras frontalmente, as imagens desaparecem pois o vidro reflete a água e cria uma espécie de espelho horizontal, ocultando as imagens que estão abaixo dele. Ao se aproximar das obras o espectador tem primeiramente a impressão de que a imagem flutua na superfície da água e, posteriormente, ao visualizar a obra de cima, vê a imagem no fundo do aquário, refletida e multiplicada pelos reflexos das paredes de vidro laterais.

Em algumas das peças que compôem a instalação "Libélulas", introduzi em pequenos aquários apenas uma "asa" feita de metal, que era duplicada através da reflexão proporcionada pelo vidro e pela água, criando a ilusão do corpo completo da libélula. Se nas instalações deixo a cargo do observador a movimentação ao redor da obra, de modo que ele descubra por si mesmo os reflexos que pretende observar, na série de fotos que venho realizando mais recentemente procuro fixar 
estes reflexos, sem entretanto eliminar a sua dubiedade e sem tornar clara sua procedência. A dúvida causada pelo reflexo óptico deve levar o observador a uma reflexão mental sobre o espaço e as imagens do mundo.

Em alguns trabalhos de Klaus Rinke é possível notar também este interesse pela reflexão. Em algumas de suas esculturas, o artista pendura pêndulos verticais que quase tocam a superfície da água. A estabilidade horizontal da superfície aquática reflete estes objetos de maneira delicada e precisa. Em algumas videoinstalações de Fabrizio Plessi, a reflexão da imagem eletrônica na água é utilizada de modo a criar paradoxos entre a ilusão e a realidade. Reflexão e refração são também questões fundamentais em várias das instalações de Olafur Eliasson. A reflexão e a refração aparecem de forma mais ou menos intencional no trabalho de inúmeros outros artistas, que não seria possível esgotar neste estudo.

As poéticas do reflexo e da refração, aliadas à poética da transparência, encerram um universo infinito de indagações a respeito da imagem e da existência, do uno e do duplo, da presença e da ausência, do real e da ilusão, da matéria e do espírito.

Tentar examiná-las a fundo apenas com o auxílio das palavras seria tarefa inacabável. Melhor observá-las em seu mundo tênue, silencioso e fascinante. 


\subsubsection{Flutuação como elevação}

A sensação do peso e a sensação da leveza são mãe e filha uma da outra. Ao mesmo tempo que uma gera a outra, elas se auto-destróem com uma ira mortal comum a ambas.

A capacidade de certos corpos permanecerem na superfície da água, como se não tivessem peso é chamada de flutuação. Embora a força da gravidade também atue no meio aquático, as contra-forças do empuxo, que dependem da densidade do líquido, parecem contrariar a ordem natural das coisas. Quando mergulhamos em um ambiente aquático, percebemos nosso corpo de maneira diferente; não necessitamos mais nos equilibrar sobre nossos pés, sentimo-nos relaxados e envolvidos por uma matéria que nos acolhe e refresca. O prazer que sentimos em flutuar na água faz-nos lembrar do tempo em que flutuávamos no útero materno.

O peso que carregamos em nosso corpo no ambiente terrestre parece desaparecer no meio aquático. Tradicionalmente associamos o peso ao corpo e às dificuldades da vida terrena, enquanto que a leveza remete ao espírito e ao etéreo. Em nossa orientação espacial natural consideramos o que está na parte superior como mais importante, poderoso e divino, e o que está na parte inferior é tido como negativo, subalterno e desprezível. A arte medieval está repleta de exemplos pictóricos em que a posição superior do quadro é reservada às divindades e às figuras poderosas e a parte inferior destina-se à representação da terra ou do inferno.

A flutuação é uma espécie de vôo sem esforço, que embora possa ser parcialmente experimentada pelo homem no meio aquático, é exclusividade dos espíritos no meio terrestre. A flutuação na água é permitida com uma certa dificuldade ao homem comum; flutuar sobre a água, porém, é possível apenas para criaturas divinas. $\mathrm{Na}$ Bíblia, "o espírito de Deus pairava sobre a face das águas" e Jesus Cristo caminhou sobre o mar. Entre os homens, apenas os magos e bruxos teriam a capacidade de flutuar. Na Idade Média era comum atirar as mulheres tidas como bruxas às àguas, para verificar se elas realmente tinham um pacto com o demônio. Se elas flutuassem, então seriam realmente bruxas, pois a sua lida com o demônio teria tornado seus corpos mais leves e puramente espirituais. Se elas afundassem, seriam pobres inocentes, que porém eram tragadas pelas águas. Tratava-se de um método eficaz, que não deixava suspeitos, pois eliminava todas, qualquer que fosse seu julgamento. Na Alemanha existem diversos documentos sobre esta prática chamada de prova da água (Wasserprobe), inclusive com citação dos nomes dos envolvidos. 
A associação entre a flutuação e a espiritualidade aparece também no emprego cotidiano das palavras. Aquilo que flutua, eleva-se no meio aquático. A palavra elevação pode tanto receber um sentido objetivo, como deslocamento de um corpo para cima, ou um sentido metafórico, relacionado à elevação espiritual. Em alemão, a palavra que significa sublime (Erhaben), difere em apenas uma letra da palavra elevar (Erheben). Elevado e sublime são também sinônimos em português.

A dimensão metafísica da flutuação serve como tema para vários trabalhos de arte, até mesmo na modernidade. Sobretudo entre os surrealistas, especialmente nas obras de Magritte, é possível observar este interesse. Em diversos de seus quadros, rochas ou pessoas flutuam sobre a terra e sobre as águas.

$\mathrm{Na}$ arte contemporânea pode-se encontrar também alguns exemplos. Em um dos vídeos do artista vietnamita Jun Nguyen Hatsushiba, um grupo de pessoas tentam arrastar riquixás no ambiente submarino. A leveza com que seus corpos flutuam, a dificuldade de movimentar-se no ambiente aquático e o aspecto ritualístico da ação conferem ao vídeo uma poesia misteriosa e mística de extrema beleza. A flutuação é tematizada também pelos alemães Horst Hoheisel e Andreas Knitz em seu projeto para o memorial das torres gêmeas do World Trade Center. Em sua proposta, duas torres idênticas às originais seriam colocadas horizontalmente a flutuar na água, simbolizando ao mesmo tempo a queda, o repouso e o fantasma da catástrofe de sua destruição.

Em vários de meus aquários utilizei fenomenologicamente a flutuação de esculturas de parafina no meio líquido. $O$ que busquei ali, foi uma espécie de equilíbrio de forças, entre o peso das peças e a água. A sugestão de paisagens sublimes, em que grandes massas se apóiam na delicadeza da água também me motivou. No vídeo "Ophelia" volto a tratar da flutuação, porém de maneira um pouco menos idealizada. Apesar de sua conotação romântica, o corpo que flutua aqui está sujeito à deterioração e ao confronto com o espaço urbano.

A palavra flutuação possui também um segundo sentido, ligado à incerteza e a instabilidade. No jargão econômico é comum ouvirmos a expressão flutuação cambial. A gíria "estou flutuando" ou "estou boiando" também se refere à incerteza. Em alemão, é apenas este sentido de instabilidade que recebe o nome de flutuação (Fluktuation) originário do latim. A flutuação dos corpos no meio líquido recebe o nome de Auftrieb (auf=para cima; Trieb=impulso).

Flutuar é de fato uma tarefa instável, embora almejada idealmente pelo homem. Se na arte do passado a flutação pode ser fixada em imagem de representação e ligase geralmente à conteúdos religiosos específicos, na arte contemporânea esta 
flutuação é experimentada de maneira fenomenológica, e portanto mais instável e sujeita aos desígnios do mundo material. Porém seu simbolismo espiritual, embora não se vincule mais atualmente a este ou àquele credo e apresente-se na arte contemporânea de maneira mais difusa e distanciada, não foi totalmente descartado - apenas atua de modo mais silencioso e sutil. 


\subsubsection{Fluidez como transformação}

A fluidez é provavelmente o fenômeno mais característico dos líquidos. Enquanto a transparência, a reflexão e a flutuação relacionam-se principalmente aos aspectos ópticos e espaciais, a fluidez inclui também a dimensão do tempo. Quando falo em fluidez, penso não apenas na fluidez mecânica, ou seja, no deslocamento dos líquidos no espaço, mas também nos processos de mudança de estado e de dissolução das matérias. Todos estes processos estão inter-relacionados e remetem a idéia de transformação. É no transcorrer dos minutos, das horas ou dos séculos que eles se desenvolvem e portanto servem como metáforas para a fugacidade da vida e a impossibilidade de se conter o tempo.

A fluidez só é possível graças a forma informe dos líquidos. A água adequa-se ao recipiente que a contém e sempre busca expandir-se em busca dos níveis topográficos mais baixos. A utilização de um material informe como a água nas instalações, esculturas e performances dos artistas contemporâneos traz um questionamento de base para o pensamento artístico, já que até o modernismo a arte estava fundamentada na formalização da matéria. A escultura tradicional teria como objetivo dar forma a uma matéria indefinida, para assim individualizá-la através de um investimento de significado. A matéria era de certa maneira sublimada e ocultada pela forma, servindo quase como um suporte neutro para a vontade formal do artista.

O aumento do interesse pela matéria na escultura pode-se observar já nos trabalhos de Rodin e Brancusi, porém neles a forma ainda é preponderante. A partir da segunda metade do século XX surge um novo interesse pela matéria em seu estado bruto e informe. Isto se destaca principalmente no trabalho de Joseph Beuys e dos artistas da Arte Povera. A dialética entre forma e matéria já foi tematizada por inúmeros comentadores da arte. Um dos estudos mais aprofundados sobre 0 assunto é o livro "Formless" de Rosalind Krauss e Yve-Alain Bois. Algumas das questões levantadas pelos autores parecem-me úteis para a análise da utilização dos líquidos na arte.

Para estes autores, o informe seria antes de mais nada uma operação que deslocaria tanto a forma como o conteúdo. A idéia de informe seria destituída de um significado. As obras que tratam do informe seriam significantes, porém sem um significado conceitual. Teriam valor mais como uma operação do que como uma matéria portadora de significado. Krauss e Bois evitam destacar o caráter simbólico 
da matéria, pois interessam-se mais por trabalhos em que a busca do artista baseiase principalmente nos aspectos fenomenológicos do material. Creio que embora esta postura seja interessante para explicar determinados trabalhos contemporâneos, é necessário, em muitos casos, também considerar o investimento simbólico da matéria.

Yves-Alan Bois e Rosalind Krauss indicam determinados processos relacionados às matérias informes. Alguns destes processos são de especial interesse no estudo da utilização da água na arte contemporânea. São eles: horizontalidade, pulsação e entropia.

Com relação a idéia de horizontalidade, Krauss afirma que a operação horizontalizante tem um efeito transgressor em relação a tradicional verticalidade imposta pela pintura e pela arte anterior à contemporaneidade. A verticalidade, apesar de ser um dos orgulhos do homem, por diferenciá-lo dos outros animais, seria de alguma forma repressora, pois distancia o homem do seu corpo e sensualidade, favorecendo apenas o intelecto. Enquanto a visualidade tradicional da arte estaria relacionada à contemplação e à posição vertical do homem, a horizontalidade colocaria o homem em contato com o mundo que o cerca, acentuando sua corporeidade. A verticalidade está para a representação assim como a horizontalidade está para a ação.

Alguns artistas modernos usaram da horizontalidade para introduzir novas operações em seus trabalhos. Pollock talvez seja um dos mais conhecidos. Seu trabalho era feito quase sempre horizontalmente e a tinta, quase líquida, espirrada sobre a tela. A sua ação corporal é de algum modo captada pela maneira como a tinta se distribui pelo quadro. Em seu trabalho a tinta é claramente percebida como líquida, e não como pastosa. A tinta não é formalizada por um gesto determinante do pincel, mas atirada, sofrendo a ação da gravidade e da aceleração.

Rosalind Krauss destaca também os trabalhos da série "Oxidation" de Andy Warhol. Nestes trabalhos, Warhol "imitaria" ironicamente a pintura gestual, porém ao invés de atirar tintas com o pincel, Warhol convidava os amigos a urinar sobre a tela, de modo que o acido úrico criava manchas e oxidações sobre a tinta úmida. É interessante aqui como o elemento líquido novamente aparece, porém não como tinta mas como fluido corporal.

A horizontalidade destaca-se também no trabalho de vários outros artistas citados em minha pesquisa. A água que escorre pelas ruas na intervenção de Olafur Eliasson na Bienal de Johannesburgo, o derramar dos tonéis cheios d'água de Klaus Rinke, as poças d'água de Kirsten Pieroth, a maneira como Síssi Fonseca lava o 
chão com seu corpo, as esculturas ao nível do solo de Carlos Fajardo nas quais a água repousa ou flui, as linhas formadas pela superfície aquática em meus "rios" encaixotados - em todos estes trabalhos a horizontalidade impõe-se definitivamente.

Além da horizontalidade, também a idéia de pulsação é associada ao informe. A pulsação como um movimento repetitivo e contínuo pode ser identificada como uma operação que favorece o informe, por impedir a constituição de uma formalização. A idéia de pulsação seria associada aos processos vitais do corpo, se opondo aos processos intelectuais, e, segundo Krauss e Yves-Alan Bois, contradizendo a pura visualidade. A arte modernista teria excluído a temporalidade do campo visual, que a pulsação do informe de alguma forma reporia. A pulsação se aproximaria da corporeidade e da atração sexual. O envolvimento com a matéria informe se daria por essa via. A pulsação é de certa maneira uma espécie de fluidez fragmentada.

No trabalho da artista Rebecca Horn esta pulsação está bastante presente. A sua utilização de líquidos vermelhos e de mecanismos tecnológicos, que colocam os líquidos em movimento, aumentam a associação entre corpo e pulsação. Também na video-instalação "He weeps for you de Bill Viola, na qual uma gota d'água pinga incessantemente; na obra "Entre" de Nuno Ramos, em que água e vinagre circulam entre esculturas de vidro; ou na instalação do grupo Chelpa Ferro na Bienal de Veneza, em que uma superfície de água vibra através da emissão de ondas sonoras é possível perceber a pulsação.

A última operação associada ao informe identificada por Yves-Alan Bois e Rosalind Krauss em "Formless" seria a entropia. A entropia é um processo irreversível de desgaste e troca de energia. Quando se coloca por exemplo dois líquidos de temperaturas diferentes em um ambiente fechado, a tendência é que eles atinjam depois de um tempo uma mesma temperatura. A menos que haja uma interferência externa de uma outra fonte energética, este equilíbrio tende a se manter. $\mathrm{Na}$ natureza a matéria está em constante processo de transformação e desgaste. Este desgate que destrói a forma e faz com que as matérias se misturem em composições heterogêneas e indiferenciadas seria uma das maneiras com que a entropia pode contribuir para a constituição do informe.

O conceito de entropia está na base das formulações dos artistas ligados à Land Art. Os trabalhos destes artistas, como Robert Smithson ou Andy Goldsworthy por exemplo, já foram analisados nesta tese. Também os processos de evaporação, congelamento ou dissolução são ligados à idéia de entropia. O interesse por estes processos é bastante presente nos trabalhos dos artistas da Arte Povera ou nas obras de Hans Haacke ou Laura Vinci, para citar apenas alguns. 
O fato é que a fluidez, quer seja pelos processos mecânicos de deslocamento dos líquidos, quer seja pelos processos entrópicos de mudança de estado e de dissolução, assinala a transformação das matérias e o seu caráter efêmero .

A diminuição da crença do homem contemporâneo na eternidade reflete-se na produção de obras de arte que se consomem em pouco tempo. A presença dos líquidos em várias destas obras apresenta-se como metáfora para a fluidez da vida... 


\subsection{Considerações finais}

A fluidez do pensamento artístico e a maneira informe com que se articula entre a razão e a sensibilidade representam um desafio para o desenvolvimento de uma tese em artes. Optei por juntar em um mesmo barco a reflexão sobre minha produção artística e a observação do trabalho de outros artistas que também trabalham com água. Creio que assim pude estabelecer diálogos entre artistas e obras, e mesmo que não seja possível que todas as relações se tornem claras, ao menos é possível reconhecer alguns dos peixes que compõem este cardume. A variedade de procedimentos e concepções dos diferentes artistas mencionados neste trabalho é o que torna mais interessante o estudo das poéticas líquidas. Não acredito que a presença da água seja responsável pela fundação de um estilo ou gênero artístico. É exatamente pela implosão das categorias na arte contemporânea que a presença da água se manifesta. Porém é possível identificar certas direções para onde flui a significação destes trabalhos. A herança histórica do uso da água nas culturas, bem como a maneira como ela é representada pela arte do passado, servem como fonte para o artista contemporâneo. Sua experiência atual de mundo acrescenta significados a este imaginário aquático, ora desviando seu curso, ora mergulhando em suas profundezas. Por utilizar a água como material, e não apenas como tema, a arte contemporânea destaca a observação fenomenológica da matéria. É possível identificar relações entre os fenômenos e sua significação simbólica; estas relações ocorrem de maneiras mais ou menos intencionais nos diferentes artistas. Em determinados artistas existe um interesse maior pelas questões da percepção e pelos processos líquidos em si. Em outros, estes processos são investidos de conotações simbólicas mais narrativas. Em todos os casos, porém, é trabalho da arte investigar e propor novas relações de significados e novos processos criativos.

É impossível pensar a presença da água na arte sem se referir aos conceitos de paisagem. Embora na contemporaneidade a água muitas vezes pareça desnaturalizada, sua presença como elemento oriundo da natureza acaba retornando no trabalho dos artistas. A observação da água como elemento natural é mediada tanto pelo discurso religioso e cultural, como pelo discurso científico. Se as questões do Sublime e da espiritualidade estão presente na origem do pensamento da água na arte, na contemporaneidade elas aparecem de forma menos idealista, porém ainda assim atuante.

A realização deste trabalho possibilitou-me refletir também sobre meu próprio trabalho como artista. A pesquisa teórica foi acompanhada da produção artística, não sendo necessariamente uma precedente à outra, mas como dois rios que 
correm paralelos e em algum local se encontram. Percebo que ao mesmo tempo que encontro referências e afinidades com determinados artistas, meu trabalho busca também seus próprios caminhos. A questão da paisagem e as relações conflituosas entre a natureza e a cultura na sociedade contemporânea tem se afirmado cada vez mais em minha trajetória. Reconheço uma oscilação proposital entre a observação do fenômeno e a narrativa simbólica em meu trabalho. É este navegar incerto, este marulho ondulante que garante minha liberdade. Uma vontade de colocar as coisas em suspensão, para que tudo flutue, inunda minha obra. Não se trata de um mar revolto, de um barco sem porto e sem âncora, mas de um desejo de mergulho e do prazer de vir à tona. É difícil chegar ao fim quando se fala de água. Pois a água continua por todos os lados. Gosto de pôr água em caixas. Porém não é possível estancá-la de vez. Sempre é possível ver através. E há reflexos e reflexões. No fundo há sempre algo. Na superfície também. O corpo está ali mergulhado. Por ali o pensamento nada. Mais, nada. 


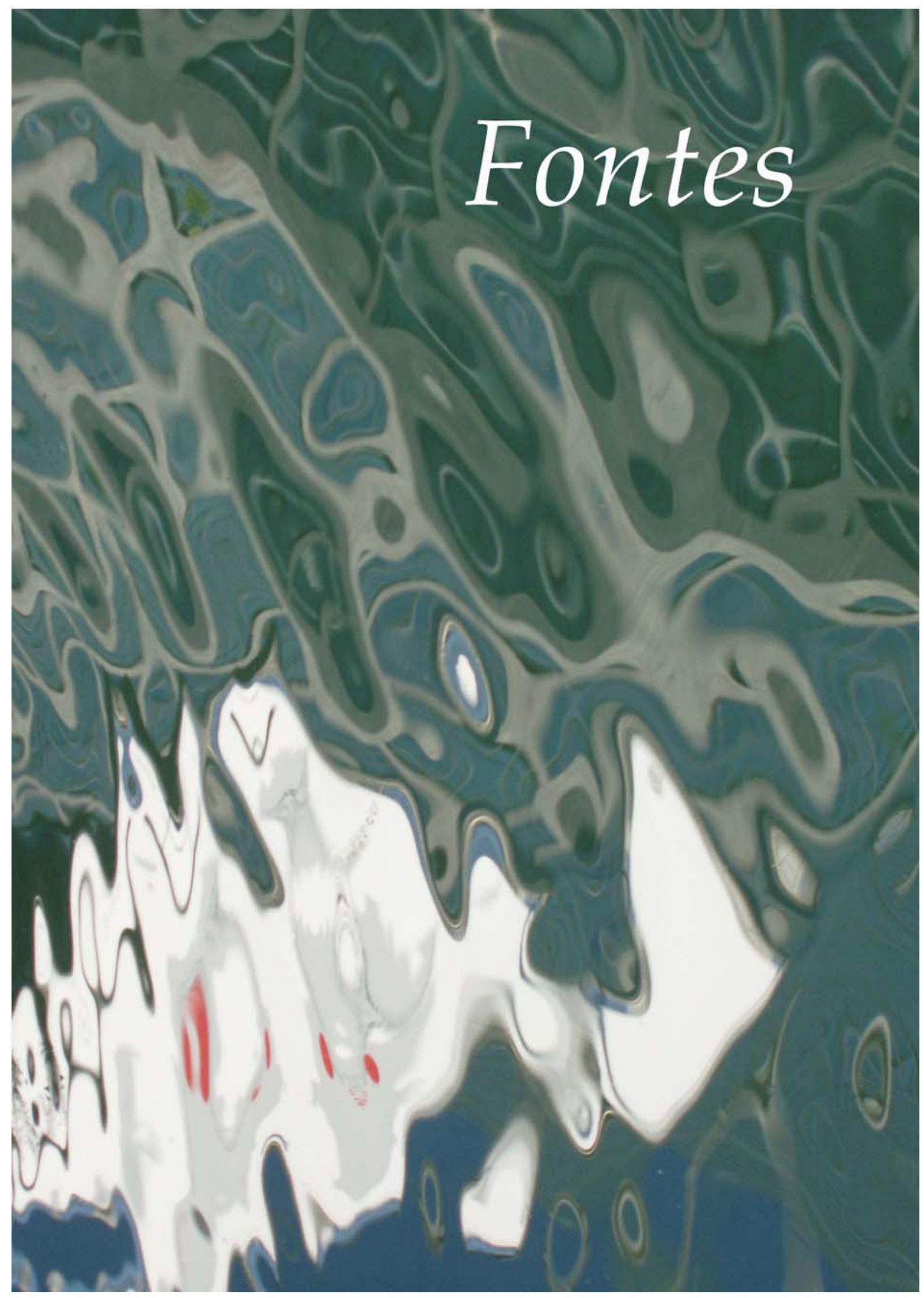




\section{Bibliografia}

\section{Bibliografia em Português}

ACOSTA, Daniel A. Paisagem Portátil: Arquitetura da natureza estandardizada. Tese de Doutorado, São Paulo: ECA/USP, 2005.

ARCHER, Michael. Arte contemporânea: uma história concisa. São Paulo: Martins Fontes, 2001

ARGAN, Giulio C. Arte Moderna.Do lluminismo aos Movimentos Contemporâneos. São Paulo: Editora Schwacz, 1993

BACHELARD, Gaston. A Água e os Sonhos. São Paulo: Martins Fontes, 1998.

BARROS, Manoel de. O guardador de águas. Rio de Janeiro: Record, 1998.

BOSI, Alfredo. Fenomenologia do olhar. In: NOVAES, Adauto et al. O Olhar. São Paulo: Companhia das Letras, 1988

BOCKEMÜHL, Michael. Turner. Köln: Benedikt Taschen, 1993.

CALABRESE, O. A idade Neobarroca, Lisboa: Edições 70, 1989.

CATUNDA, Leda. Poética da Maciez: Pinturas e Objetos. Tese de Doutorado. São Paulo: ECA-USP, 2003.

FARIAS, Agnaldo A. C. Esculpindo o espaço. A Escultura Contemporânea e a busca de novos modos de relação com o espaço. Tese de doutorado. São Paulo: FAU-USP, 1997.

GREENBERG, C. Clement Greenberg e o debate crítico. Rio de Janeiro: Jorge Zahar Ed., Funarte, 2001

GROSENICK, Uta; RIEMSCHNEIDER, Burkhard. Arte Actual. Tradução: Francisco Paira Boléo. Köln: Taschen, 2001

JOHAS, Regina. Desdobramentos do Desenho no Espaço. Tese de Doutorado, São Paulo: ECA-USP, 2004. 
KANT, Immanuel. Crítica da capacidade do juízo. Rio de Janeiro: Forense, Universitária, 1995.

KANT, Immanuel. Observações sobre o sentimento do Belo e do Sublime, São Paulo: Papirus, 1993.

KRAUSS, Rosalind E. Caminhos da Escultura Moderna. São Paulo: Martins Fontes, 1998.

KYRIAKAKIS, Geórgia E. A. Buracos Planos, Duplos, Elevações. Dissertação de Mestrado, São Paulo: ECA-USP, 2001

O LIVRO DA ARTE. São Paulo: Martins Fontes, 1996.

MERLEAU-PONTY, Maurice. Fenomenologia da Percepção, São Paulo: Martins Fontes, 1994.

MAMMI, Lorenzo. O Limite da Matéria. In: Revista Bravo, Março 2000, n 30, p. 109, São Paulo: D’Ávila Comunicações Ltda, 2000.

MESQUITA, Tiago. Por baixo do nome das coisas. Catálogo da Exposição Ao Todo, realizada na Unicid, São Paulo, 2001.

PALHARES, Taísa Helena Pascale. Aura: a crise da arte em Walter Benjamin. São Paulo: Editora Barracuda, 2006

PANOFSKY, E. Idea - A evolução do conceito do Belo. São Paulo: Martins Fontes, 1994.

PAREYSON, Luigi. Os problemas da Estética. São Paulo: Martins Fontes, 1984.

QUINTANA, Mario. Água. Porto Alegre: Artes e Ofícios, 2001.

OUTEIRO, Robson. (Org.) A bigger splash: arte britânica da Tate 1960-2003.

Tradução Ana Magalhães. São Paulo: Connects Cultura, 2003.

RAMOS, Nuno. Dúvida Líqüida. In: Catálogo da exposição Dúvida Líqüida realizada na Galeria Valu Oria, São Paulo, 2001. 
RAMOS, Nuno. Fala Falante. In: Nuno Ramos. Catálogo da exposição realizada no Instituto Tomie Ohtake de fevereiro a abril de 2006. São Paulo: Instituto Tomie Ohtake, 2006.

SALZSTEIN, Sônia. Lavoura de pensamentos. In: FELIX, Nelson. Nelson Felix. Rio de Janeiro: Casa da Palavra, 2001

TASSINARI, A. O espaço moderno. São Paulo: Cosac \& Naify Edições, 2001

TASSINARI, A., MAMMI, L. \& NAVES, R. Nuno Ramos. São Paulo: Editora Atica, 1997.

TAVARES, Ana Maria. Armadilhas para os sentidos: uma experiência no espaçotempo da arte. Tese de doutorado. São Paulo: ECA-USP, 2000

VIGARELLO, Georges. O limpo e o sujo: uma história da higiene corporal. São Paulo: Martins Fontes, 1996.

WOOD, Paul. Arte Conceitual. Tradução Betina Bischof. São Paulo: Cosac \& Naify Edições, 2002.

XXIV Bienal de São Paulo (Catálogos). São Paulo: Fundação Bienal, 1998.

\section{Bibliografia em Alemão}

AKADEMIE DER BILDENDEN KÜNSTE IN NÜRNBERG. (Hrsg.) Kunst im Wasser. Anlässlich der Austellung Kunst im Wasser Kaiserburg Lauf Pegnitz, Lauf: Fahner Verlag, 2002.

BASHKOFF, Tracey (org.) Über das Erhabene: Mark Rothko, Yves Klein, James Turrell. New York: The Solomon Guggenheim Foundation, 2001.

BÖHME, Hartmut et. al. Kulturgeschichte des Wassers. Frankfurt am Main: Suhrkamp Taschenbuch Verlag, 1988.

BURKE, Edmund. Philosophische Untersuchung über den Ursprung unserer Ideen vom Erhabenen und Schönen. (1757). Übersetzt von Friedrich Bassenge, neu eingeleitet und herausgegeben von Werner Strube. Hamburg: Felix Meiner Verlag, 1989. 
BUSCH, Bernd et. al. Wasser : [anläßlich des internationalen Kongresses, der vom 21. bis 25. Oktober 1998 im Forum der Kunst- und Ausstellungshalle der Bundesrepublik Deutschland stattgefunden hat / [Hrsg. Kunst- und Ausstellungshalle der Bundesrepublik Deutschland GmbH]. Köln : Wienand, 2000.

CLAUSSEN-HENN, Ursula. Wasser im Fluß : das Lebenselement Wasser. Köln : Müller, 1992.

DA VINCI, Leonardo. Das Wasserbuch : Schriften und Zeichnungen. Ausgew. und übers. von Marianne Schneider. München [u.a.] : Schirmer/Mosel, 1996

DEAN, Tacita; MILLAR, Jeremy. Art Works Zeitgenössische Kunst: Ort. Tradução do inglês Dörte Fuchs e Jutta Orth. Hildesheim: Gerstenberg Verlag, 2005.

DEUTSCHLAND BILDER - Kunst aus einem geteilten Land. Katalog zur zentralen Ausstellung im Martin Groupius - Bau. Berlin: Eckhart Gillen, 1997

EISENBACH, Ursula et. SCHMIDT, Hans-Werner. Klaus Rinke: retroaktiv. Düsseldorf: Richter Verlag, 1992.

FEHRENBACH, Frank : Licht und Wasser : zur Dynamik naturphilosophischer Leitbilder im Werk Leonardo da Vincis. Tübingen : Wasmuth, 1997.

(Tübinger Studien zur Archäologie und Kunstgeschichte ; 16)

GOETZ, Ingvild; MEYER-STOLL, Christiane(ed.). Arte Povera: Arbeiten und Dokumente aus der Sammlung Goetz 1958 bis heute. München: Kunstverlag Ingvild Goetz G.m.b.H., 1997.

GROSENICK, Uta (ed.). Women Artists: Künstlerinnen im 20. und 21. Jahrhundert, Köln: Taschen, 2005.

GRUNDMANN, Anette. Über Wasser : Geschichten, Fakten und Mythen über Wasser und das Bad der Zukunft = Crossing the waters /1. Hoesch Design Award. [Hoesch Metall- und Kunststoffwerk GmbH, Düren. Red.: Anette Grundmann].

HOFFMANN, Gretl. Brunnen und Wasserspiele : über 190 moderne Beispiele von privaten und öffentlichen Anlagen. Stuttgart : Hoffmann, !980. 
HOFFMANN, Jens; JONAS, Joan. Art Works Zeitgenössische Kunst: Aktion. Tradução Brigitte Beier e Beatrix Gehlhoff. Hildesheim: Gerstenberg Verlag, 2005

HORN, Rebecca et. al. Rebecca Horn. Stuttgart: IFA Institut für Auslandsbeziehungen e. V., 1999.

KITTELMANN, Udo [Hrsg.] :Ausstellung Teresa Margolles - Muerte Sin Fin <2004, Frankfurt, Main> : Teresa Margolles, muerte sin fin : [anlässlich der Ausstellung Teresa Margolles - Muerte Sin Fin, 24. April - 15. August 2004, Museum für Moderne Kunst, Frankfurt am Main] .Ostfildern-Ruit : Hatje Cantz, 2004.

LINDEMANN, Inge (org.). overtures - über Wasser. anlässlich der Ausstellung overtures - über Wasser. Gelsenkirchen: Artcircolo, Gelsenwasser, 2002.

MARZONA, Egidio (Bearb.) Concept art, minimal art, arte povera, land art. Stuttgart : Cantz, 1990.

MOEHRKE, Helga [Hrsg.] Oberwasser, Unterwasser oder das Aufgehobensein im Wasser : Performance von Helga Moehrke am 19. Dezember 1987 im Schiffshebewerk Scharnebeck, Lüneburg: Kunstverein Lüneburg, 1987.

RINKE, Klaus: Klaus Rinke, Wasser + Schwerkraft = Harmonie $:$ Kunsthalle zu Kiel, 24.7. - 13.9.1992 / [Ausstellung u. Katalog: Klaus Rinke und Hans-Werner Schmidt]. - Kiel : Kunsthalle, 1992.

SCHLÜTER, Ralf. Schock und Leere (Frankfurt: Teresa Margolles). art, Hamburg, n.7, p.102-103, Juli 2004.

Schwenk, Theodor:

SCHWENK, Theodor. Das sensible Chaos : strömendes Formenschaffen in Wasser und Luft. Stuttgart : Verl. Freies Geistesleben, 1968

STICH, Sidra. Yves Klein. Stuttgart: Cantz Verlag, 1994

ULRICHS, Timm. Gehäuse für Denkmäler und Brunnen (Katalog).Freiburg im Breisgau/München : Modo-Verl., 2000.

WASSER im Fluß: Das Lebenselement Wasser . Köln: R. Müller, 1992. 
WAGNER, Monika et. al. Lexikon des künstlerischen Materials. München.: Verlag C.H. Beck oHG, 2002.

WOLF, Norbert. Caspar David Friedrich. Köln: Taschen, 2003

WULLEN, Moritz. Die Prärafffaeliten: Natur als Vision. In: Natur als Vision. Katalog der Ausstellung der Tate Britain in Zusammenarbeit mit der Nationalgalerie Berlin. Berlin: SMB DuMont, 2004.

\section{Bibliografia em Inglês}

BALDOCK, Karen; GALAN, Gerdien de. (ed.) Water an art walking route in the Amsterdam Water Supply Dunes. Edição Bilíngue: Inglês e Holandês. Amsterdam: Waterleidingbedrijf Amsterdam, 2003

BOIS, Yve-Alain; KRAUSS, Rosalind. Formless: A User's Guide. New York: Zone Books, 1997

CELANT, Germano. Art Povera. In: HARRISON, Charles et. WOOD, Paul. Art in Theory 1900-1990. An Anthology of Changing Ideas. Reino Unido: Blackwell Publishers, 1992.

CELANT, Germano et. al. Rebecca Horn. New York: Guggenheim Museum, 1993

ELIASSON, Olafur; Grynstejn, Madeleine et. al. Olafur Eliasson. London : Phaidon Press, 2002

FOSTER, Hal. Vision and visuality. New York: The New Press, Dia Art Foundation, number 2

HARRISON, Charles et. WOOD, Paul. Art in Theory 1900-1990. An Anthology of Changing Ideas. Reino Unido: Blackwell Publishers, 1992.

HOBBS, Robert. Robert Smithson: a retrospective view. Ithaca, New York: Herbert F. Johnson Museum of Art, Cornell University, s.d. 
HORN, Roni. Dictionary of water. Göttingen : Steidl, 2001.

KASTNER, Jeffrey. (ed.). Land and environmental art. London : Phaidon Press, 1998.

KRAUSS, Rosalind E. Sculpture in the Expanded Field. In: The Originality of the Avant-Garde and Other Modernist Myths. Cambridge: The MIT Press, 1985.

LUCIE-SMITH, Edward. ARTODAY, Londres: Phaidon, 1995.

NERI, Louise. Looking up : Rachel Whiteread's water tower ; a project of the Public Art Fund. New York: Public Art Fund, 1999

PAPADAKIS, Andreas et. al. New Art. New York: Rizzoli International Publications, 1991.

SPALDING, Frances. The Tate Gallery. London: Tate Gallery Publishing, 1998

\section{Bibliografia em Francês}

SAGNER-DÜCHTIN, Karin. Monet. Köln: Taschen, 2004.

TAILLANDIER, Yvon. Claude Monet. Paris: Flamarion, 1967. 


\section{Sobre o autor}

\section{Exposições Coletivas}

2006 Off Copa - Galeria Berlin am Meer - Berlim - Alemanha

Gyumri Biennial - Gyumri - Bienal da Armênia

Água Corrente - Centro Cultural São Paulo - São Paulo - Brasil

Videoformes International Video Festival - Clermont-Ferrand - França

Alles Fließt - Lichtblick-Kino - Berlim - Alemanha

Athens Video Art Festival - Atenas - Grécia

Festival Corta Curtas - Coletivo Cine Falcatrua - Rumos Itaúcultural - São Paulo

2005 KunstFilmBiennalle - Bienal de Filmes de Arte de Colônia - Alemanha

Brésil Ecosophie - Galeria Artcore - Paris - França

15 Videobrasil International Eletronic Art Festival -São Paulo - Brasil

Discover Brasil - Ludwig Museum - Koblenz - Alemanha

Prog:ME International Eletronic Art Festival - Rio de Janeiro - Brasil

Sempre Visível/Projeto Linha Imaginária - Centro Cultural São Paulo - Brasil

Cross the River - Internationales Forum der Kunst und Kultur - Berlim - Alemanha

International Art Colony Castle Almoshof - Nuremnberg - Alemanha

Luft Addition - Allgemeiner Konsumverein - Braunschweig - Alemanha

2004 Lightsigns - Academia Real de Artes - Copenhagem - Dinamarca

Lightsigns - Embaixada Nórdica - Berlim - Alemanha

Rundgang - Universität der Künste - Berlin - Alemanha

2003 Mostra dos Selecionados - Centro Cultural São Paulo - São Paulo - Brasil

Arte Hoje - Galeria Valu Oria - São Paulo - Brasil

Ponto de Fuga/Área Livre - Projeto Linha Imaginária - Memorial da América Latina Sao Paulo - Brasil

Espaço Comum - MARP - Museu de Arte de Ribeirão Preto - Brasil

Espaço Comum - Centro Cultural UFMG - Belo Horizonte - Brasil

Arte do Novo Século - Secretaria de Cultura de Jundiaí - Brasil

2002 ARCO - International Fair of Contemporary Art - Madrid - Espanha

Arte-Papel - Galeria Valu Oria - São Paulo - Sao Paulo - Brasil

Ares e Pensares - SESC Santana e SESC 24 de maio - São Paulo - Brasil

Genius Loci - Centro Universitário Maria Antônia - São Paulo - Brasil

Salão de Arte Contemporânea de Piracicaba - Piracicaba - SP - Brasil

Desvio - Funarte - São Paulo - Brasil

A Revolução não será Televisionada - Fundição Progresso - Rio de Janeiro

2001 Dúvida Líquida - Galeria Valu Oria - São Paulo - Brasil

Pequenos Formatos - Galeria Valu Oria - São Paulo - Brasil

O Corpo do Espaço - SESC São Carlos - Brasil

Refração - SESC Araraquara - Brasil

Ao Todo - UNICID - Universidade Cidade de São Paulo - Brasil

2000 SESC Pompéia - Entretantos - São Paulo - Brasil

Paço das Artes - Dadá é mais que dadá - Curada por Timm Ulrichs- São Paulo -

Brasil

1999 Buracos - Capela do Morumbi - São Paulo - Brasil

1998 Visualidade Nascente - Centro Cultural Maria Antônia - São Paulo - Brasil

Salão de Arte Contemporânea de São Bernardo - Espaço Henfil - São Bernardo do

Campo - Brasil 


\section{Exposições Individuais}

2004 Übergang - Galeria Schiller Pallais - Berlim - Alemanha

2003 Hugo Fortes - Programa dos Selecionados - Centro Cultural São Paulo Brasil

2002 Inventário de Horizontes - Centro Universitário Maria Antônia - USP - São Paulo

2000 Entre o Design e a Arte - ECA-USP - São Paulo - Brasil

1997 Trajetos - Galeria da Consolação - São Paulo - Brasil

1997 Poço - Casa de Cultura de Santo Amaro - São Paulo - Brasil

1994 Fios D’Água - Casa de Cultura da Freguesia do Ó - São Paulo - Brasil

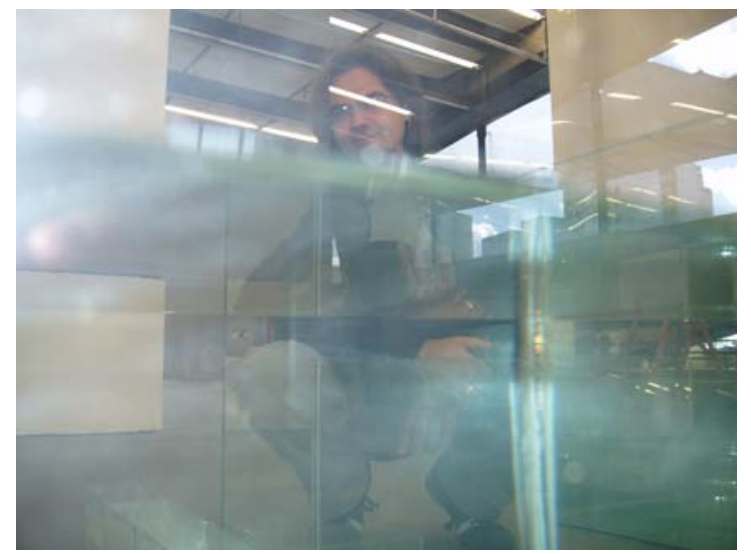

\section{Hugo Fortes}

Nasce em 1968 em Araraquara, SP.

1986 a 2003, vive e trabalha em São Paulo.

2004 a 2006, vive e trabalha em Berlim, Alemanha.

A partir de abril de 2006, vive e trabalha em São Paulo.

Artista Plástico, Professor Universitário, Pesquisador e Designer Gráfico.

Doutorado em Artes realizado na ECA-USP, São Paulo, e na Universität der Künste Berlin, Alemanha, como bolsista DAAD/CAPES.

Mestrado em Comunicação na ECA-USP, como bolsista da FAPESP.

Graduação em Comunicação (Publicidade e Propaganda) na ECA-USP, São Paulo. 
Créditos das Fotos: Este trabalho reúne fotos de Hugo Fortes, André Fortes, Síssi Fonseca, Horst Koehler, Caio Reisewitz, e diversos outros fotógrafos que não puderam ser identificados. 
${ }^{1}$ BÖHME, Hartmut et. al. Kulturgeschichte des Wassers. Frankfurt am Main, Suhrkamp Taschenbuch Verlag, 1988

2 Versão em Português traduzida pelo autor a partir do texto original:

Wir trinken nicht einfach Wasser, sondern nehmen einen Schluck, der die Lippen benetzt, den Mund füllt, die Kehle hinabrinnt und in Magen gluckert - das ist: Wasser im physiologischen Schema der Trinkbewegung, es schmeckt weich, süß, säuerlich, abgestanden, prickelnd - das ist: Wasser im geschmacklichen Schema; wir trinken es in gierigen Zügen, Sclückchen für Schlückchen, als Begleitung zum Essen oder abwechselnd mit Wein - das ist: Wasser im Schema des Durstes und der kultivierten Trinksitten; wir trinken es in Berlin aus einer Flasche, die in der Auvergne mit Wasser aus den Tiefen des Vulkangesteins abgefüllt wurde - das ist: Wasser als industrielles Produkt mit dem Gütesiegel hochbesetzter "Natureinheit" , wir trinken es, weil wir die hydrologische Analyse auf dem Etikett gelesen haben-das ist Wasser als Objekt chemischer Analyse; wir trinken es aufgrund seiner Mineralienzusammensetzung - das ist: Wasser im Schema diätetischen Wissens; wir trinken es aus einer Glas-, nicht Plastikflasche - das ist: Wasser im Schema ökologischen Wissens; wir geben für dieses Wasser mehr Geld aus - das ist: Wasser im Schema von Geldwert, der von vielen Faktoren bestimmt wird: Herstellungskosten, Transportwege, Marktlage, Markenprestige, Kundenbewußtsein, Trinkgebräuche. Extraído de:

BÖHME, Hartmut. Anthropologie der vier Elemente. In: BUSCH, Bernd et. al. Wasser : [anläßlich des internationalen Kongresses, der vom 21. bis 25. Oktober 1998 im Forum der Kunst- und Ausstellungshalle der Bundesrepublik Deutschland stattgefunden hat / [Hrsg. Kunst- und Ausstellungshalle der Bundesrepublik Deutschland GmbH]. Köln : Wienand, 2000. (p. 17-18)

${ }^{3}$ In: WASSER im Fluß: Das Lebenselement Wasser . Köln, R. Müller, 1992.

${ }^{4}$ DETEL, Wolfgang. Das Prinzip des Wassers bei Thales.. In: BÖHME, Hartmut et. al. Kulturgeschichte des Wassers. op.cit. (p.43-44)

5 "Es werde eine Feste zwischen den Wassern, und die sei ein Unterschied zwischen die Wassern."

${ }^{6}$ DETEL, Wolfgang. Das Prinzip des Wassers bei Thales. In: BÖHME, Hartmut et. al. Kulturgeschichte des Wassers. op.cit. (p.46-47).

${ }^{7}$ Schütt, Hans-Werner . Vom Element zur Verbindung. In: Wasser: [anläßlich des internationalen Kongresses, der vom 21. bis 25. Oktober 1998 im Forum der Kunst- und Ausstellungshalle der Bundesrepublik Deutschland stattgefunden hat]/[Hrsg. Kunst- und Ausstellungshalle der Bundesrepublik Deutschland GmbH]. Wiss. Red. Bernd Busch und Larissa Förster - Köln: Wienand, $2000 \cdot(\mathrm{p} .39)$

${ }^{8}$ DETEL, Wolfgang. Das Prinzip des Wassers bei Thales. In: BÖHME, Hartmut et. al. Kulturgeschichte des Wassers. op.cit. (p.43-44)

9 Fleuma ou Pituíta: Na antiguidade, secreção mucosa que se acreditava ser produzida pelo encéfalo e eliminada pelo nariz. In: FERREIRA, Aurélio Buarque de Holanda. Novo Aurélio Século XXI: o dicionário da língua portuguesa. Rio de Janeiro, Nova Fronteira, 1999

${ }^{10}$ In: Bachelard, Gaston. A água e os sonhos. Op. Cit. p. 4

${ }^{11}$ Homunculus: pequena criatura imperfeita criada artificialmente pelo homem. 
12 "Ich staune über das Sieden des Wassers und der Menschen, die mitverbrennen und doch leben". In: Schütte, Hans Werner. Vom Element zur Verbindung. In: Wasser. op.cit.

13 Wandlung, em alemão significa transformação em geral, mas também a transformação do pão e vinho no corpo e sangue de Jesus Cristo.

${ }^{14}$ BACHELARD, Gaston. A água e os sonhos. p.140. op. cit.

${ }^{15}$ VIGARELLO, Georges. O limpo e o sujo: uma história da higiene corporal. São Paulo: Martins Fontes, 1996.

${ }^{16}$ In: FEHRENBACH, Frank. Licht und Wasser: zur Dinamik naturphilosophischer Leitbilder im Werk Leonardo da Vincis. Tübingen; Berlin: Wasmuth Verlag, 1997.

${ }_{17}$ Tradução Prof. Donato Ferrari. Texto original em italiano: corpi lucidi, nebbie, tempi oscuri, pioggie, superfitie delle acque, variamento del colore dell'aria, la polvere,(...) li fiumi più o men densi, pesci scherzanti.Extraído dos parágrafos 38 e 40 ( manuscritos =A103v), de Leonardo Da Vinci, conforme citado por FEHRENBACH, Frank. Licht und Wasser: zur Dynamik naturphilosophischer Leitblider im Werk Leonardo da Vincis. Tübingen; Berlin: Wasmuth, 1997

18 SEIDERER, Ute. Die Zeit und die Flüsse. In: Wasser: (anläßlich des internationalen Kongresses, der vom 21. bis 25. Oktober im Forum der Kunst- und Austellungshalle de Bundesrepublik Deutschland stattgefunden hat) / (Hrsg. Kunst- und Austellungshalle der Bundesrepublik Deutschland GmbH). Wiss. Red.: Bernd Busch und Larissa Förster. - Köln: Wienand, 2000, p.195.

${ }^{19}$ ORAMAS, Luis Pérez. Paisagem e fundação: Frans Post e a invenção da paisagem americana. In: Catálogo da XXIV Bienal de São Paulo, volume 1. São Paulo, Fundação Bienal , 1998. p.102

${ }^{20}$ In: ARGAN, Giulio C. Arte Moderna.Do Iluminismo aos Movimentos Contemporâneos. São Paulo: Editora Schwacz, 1993

21 "Seja na historiografia, na geologia, nos estudos de nuvens do pioneiro da meteorologia Luke Howard ou na teoria da evolução de Charles Darwin - para todos os lados articulou-se um fascínio jamais existente pela natureza em movimento, em constante modificação." (tradução do autor). Texto original em alemão: Sei es in der Geschichtswissenschaft, der Geologie, in der Wolkenkunde des meteorologischen Pioniers Luke Howard oder in der Evolutionstheorie Charles Darwins - überall artikulierte sich eine noch nie da gewesene Faszination für die bewegte, in fortwährende "modification" begriffene Natur." In: WULLEN, Moritz. Die Prärafffaeliten:

Natur als Vision. In: Natur als Vision. Katalog der Ausstellung der Tate Britain in Zusammenarbeit mit der Nationalgalerie Berlin. Berlin: SMB DuMont, 2004.

22 BACHELARD, Gaston. A água e os sonhos: ensaios sobre a imaginação da matéria. São Paulo, Martins Fontes, 1997. p. 2

${ }^{23}$ No catálogo da XXIV Bienal de São Paulo, Valéria Piccoli comenta o trabalho de artistas contemporâneos brasileiros, onde as poéticas líquidas se fazem presentes: " no trabalho de Valeska Soares, uma escultura de cera com a forma de duas bocas unidas por um fluído, (..) o líquido é perfumado e atrai para perto, muito perto. As bocas estão cheias desse líquido, são receptáculos dessa espécie de saliva que as preenche e delas escorre. Sintomas de apetite, desejo. Ou talvez seja simplesmente uma estranha espécie de seiva que lhes sirva de alimento. (...)O tema dos fluídos está 
presente ainda nas gotas de sêmen antropomórficas de Edgard de Souza, no suco de rosas que mancha como sangue as pinturas de Courtney Smith, no líquido que escorre do Livro de Carne de Arthur Barrio ou mesmo na Baba Antropofágica de Lygia Clark(...).

${ }^{24}$ Palhares, Taisa Helena Pascale. Aura: a crise da arte em Walter Benjamin. São Paulo, Editora Barracuda, 2006

${ }^{25}$ In MC EVILLEY, Thomas. Yves Kleins doppeltes Spiel mit dem Erhabenen.Texto original em alemão: Dank seiner legendären Fähigkeit, widersprüchliche Impulse in sich zu vereinen, war er imstande, das Erhabene in seiner ganzen Tiefe zu erfasssen, um es im nächsten Moment sogleich ins Lächerlich zu ziehen." Tradução do autor. In:BASHKOFF, Tracey (org.) Über das Erhabene: Mark Rothko, Yves Klein, James Turrell. New York. The Solomon Guggenheim Foundation, 2001

${ }^{26}$ In: Picoli, Valéria. Catálogo da XXIV Bienal de São Paulo. Fundação Bienal, São Paulo, 1998.

${ }^{27}$ BOSI, Alfredo. Fenomenologia do olhar. In: NOVAES, Adauto et al. O Olhar. São Paulo, Companhia das Letras, 1988

${ }^{28}$ Flüssigkeit em alemão significa ao mesmo tempo "líquido" ou "fluidez, fluência". Em alemão não existe uma palavra específica para se designar apenas "líquido", tal conceito está sempre relacionado em sua origem com ato de fluir.

${ }^{29}$ In: ACOSTA, Daniel A. Paisagem Portátil: Arquitetura da natureza estandardizada. Tese de Doutorado apresentada na ECA-USP, São Paulo, ECA/USP, 2005. p. 17

30 TASSINARI, A. O espaço moderno. São Paulo, Cosac \& Naify Edições, 2001

${ }^{31}$ Estas idéias foram desenvolvidas pelo Prof. Dr. Robert Kudielka na disciplina "Das Bild und die Bilder" ( A imagem e as imagens) ministrada na Universität der Künste Berlin em 2005.

${ }^{32}$ Os conceitos de virtual e atual aqui utilizados baseiam-se no estudo da artista Regina Johas sobre o filósofo Pierre Levy. Johas utiliza estes conceitos para discutir as circunstâncias da imagem digital. Em sua tese de doutorado, a artista escreve: "A concretização de uma virtualidade implica, portanto, em sua atualização no espaço-tempo. No momento em que um virtual se materializa, ele responde a um determinado número de condições que cercam sua configuração material." Embora aplicando estes conceitos aqui em outro contexto, creio que sua validade permanece, pois acredito que as imagens refletidas na água, assim como as imagens digitais possuem inúmeras possibilidades de atualização. 